\title{
The In-Situ Decontamination Of Sand And Gravel Aquifers By Chemically Enhanced Solubilization Of Multiple-Component DNAPLS With Surfactant Solutions
}

\author{
Topical Report \\ January 1995
}

Work Performed Under Contract No.: DE-AC21-92MC29111

U.S. Department of Energy

Office of Environmental Management

Office of Technology Development

1000 Independence Avenue

Washington, DC 20585
For

U.S. Department of Energy

Office of Fossil Energy

Morgantown Energy Technology Center P.O. Box 880

Morgantown, West Virginia 26507-0880

By

INTERA, Inc.

6580 Austin Center Boulevard

Suite 300

Austin, Texas 78731

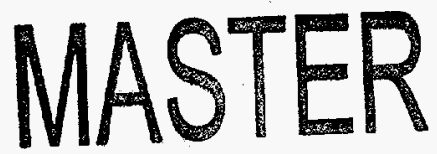




\section{DISCLAIMER}

Portions of this document may be illegible in electronic image products. Images are produced from the best available original document. 


\title{
The In-Situ Decontamination Of Sand And Gravel Aquifers By Chemically Enhanced Solubilization Of Multiple-Component DNAPLS With Surfactant Solutions
}

\author{
Topical Report \\ January 1995
}

Work Performed Under Contract No: DE-AC21-92MC29111

U.S. Department of Energy

Office of Environmental Management Office of Technology Development Washington, DC
For

U.S. Department of Energy Office of Fossil Energy

Morgantown Energy Technology Center Morgantown, West Virginia

By

INTERA, Inc.

6580 Austin Center Boulevard, Suite 300

Austin Texas 78731 


\section{DISCLAIMER}

This report was prepared as an account of work sponsored by an agency of the United States Government. Neither the United States Government nor any agency thereof, nor any of their employees, makes any warranty, express or implied, or assumes any legal liability or responsibility for the accuracy, completeness, or usefulness of any information, apparatus, product, or process disclosed, or represents that its use would not infringe privately owned rights. Reference herein to any specific commercial product, process, or service by trade name, trademark, manufacturer, or otherwise does not necessarily constitute or imply its endorsement, recommendation, or favoring by the United States Government or any agency thereof. The views and opinions of authors expressed herein do not necessarily state or reflect those of the United States Government or any agency thereof.

Available to the public from the National Technical Information Service, U.S. Department of Commerce, 5285 Port Royal Road, Springfield, VA 22161; phone orders accepted at (703) 487-4650.

This report has been reproduced directly from the best available copy. 


\title{
The In-Situ Decontamination Of Sand and Gravel Aquifers By Chemically Enhanced Solubilization Of Multiple-Component DNAPLS With Surfactant Solutions
}

\author{
Topical Report \\ January 1995
}

Work Performed Under Contract No.: DE-AC21-92MC29111

\author{
For \\ U.S. Department of Energy \\ Office of Fossil Energy \\ Morgantown Energy Technology Center \\ P.O. Box 880 \\ Morgantown, West Virginia 26507-0880 \\ By \\ INTERA Inc. \\ 6850 Austin Center Boulevard, Suite 300 \\ Austin, Texas $\mathbf{7 8 7 3 1}$
}




\section{Table of Contents}

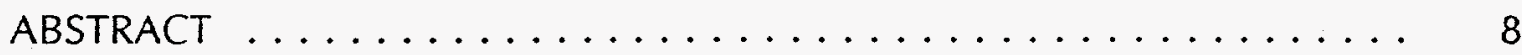

LIST OF TABLES $\ldots \ldots \ldots \ldots \ldots \ldots \ldots \ldots \ldots \ldots \ldots \ldots \ldots \ldots \ldots \ldots \ldots \ldots$

LIST OF FIGURES $\ldots \ldots \ldots \ldots \ldots \ldots \ldots \ldots \ldots \ldots \ldots \ldots \ldots \ldots \ldots \ldots \ldots \ldots$

LIST OF APPENDICES $\ldots \ldots \ldots \ldots \ldots \ldots \ldots \ldots \ldots \ldots \ldots \ldots$

ACKNOWLEDGEMENT $\ldots \ldots \ldots \ldots \ldots \ldots \ldots \ldots \ldots \ldots \ldots$

$1.0 \quad$ INTRODUCTION $\ldots \ldots \ldots \ldots \ldots \ldots \ldots \ldots \ldots \ldots \ldots \ldots$

1.1 Surfactant-Enhanced Aquifer Remediation ........... 10

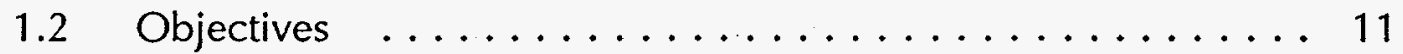

1.3 Site Selection $\ldots \ldots \ldots \ldots \ldots \ldots \ldots \ldots \ldots \ldots \ldots \ldots \ldots$

1.4 Scope Limitations $\ldots \ldots \ldots \ldots \ldots \ldots \ldots \ldots \ldots \ldots \ldots$

1.4.1 Difficulties in Contracting with Sandia National Laboratories .................... 13

1.4.2 Difficulties in Transfer of RGA Cores to SUNY-Buffalo . 14

1.4.3 Difficulties with Employment of the Preferred Surfactant . 15

2.0 LABORATORY EXPERIMENTS TO IDENTIFY AND CHARACTERIZE SURFACTANTS AND THEIR SOLUBILIZATION ACTIVITY ..... 16

2.1 Aquifer Characterization $\ldots \ldots \ldots \ldots \ldots \ldots \ldots \ldots$

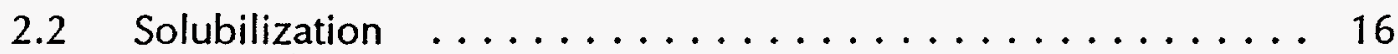

2.2.1 HLB Determination $\ldots \ldots \ldots \ldots \ldots \ldots \ldots \ldots$

2.2 .2 Solubilization of TCE $\ldots \ldots \ldots \ldots \ldots \ldots \ldots 17$

2.2.3 Solubilization of Other Contaminants ......... 18

2.2.4 Solubilization of Mixtures .............. 18

2.3 Toxicity ....................... 19

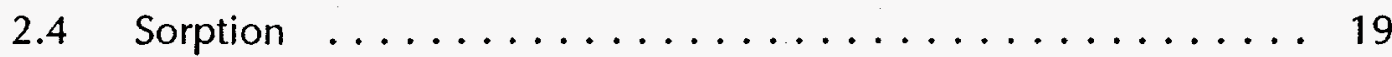

2.4 .1 Batch Tests .................... 20

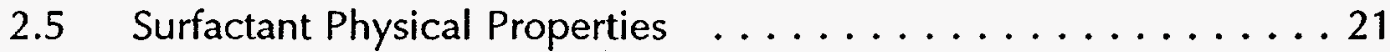

2.5.1 Interfacial Tension . . . . . . . . . . . . 21

2.5.2 Critical Micellar Concentration ............ 22

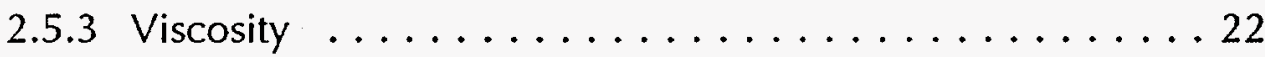




\section{Table of Contents}

(continued)

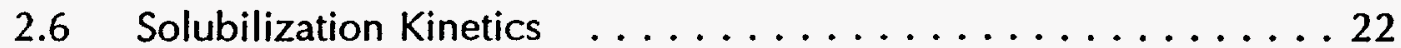

2.7 Surfactant Selection . . . . . . . . . . . . . . . . . 23

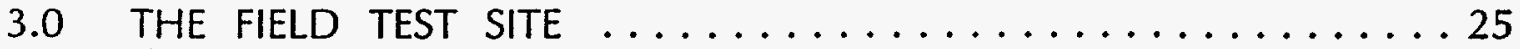

3.1 Contaminant Hydrogeology of WMU-11 . . . . . . . . . 25

3.2 Scenarios of TCE in the Regional Gravel Aquifer . . . . . . . . 26

3.3 Simulation of TCE in the Regional Gravel Aquifer . . . . . . . . 27

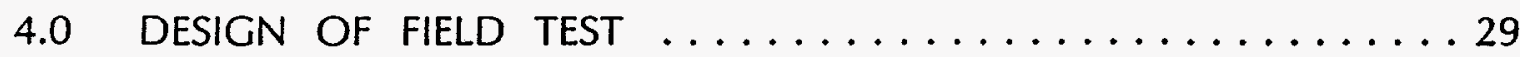

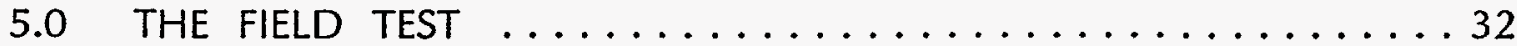

5.1 The Injection/Extraction System $\ldots \ldots \ldots \ldots \ldots \ldots \ldots \ldots$

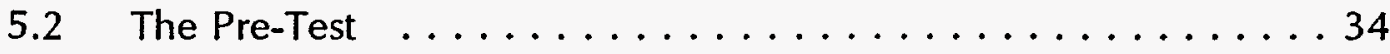

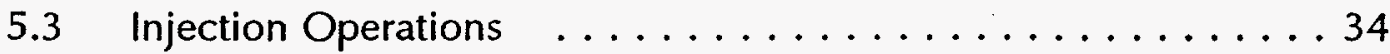

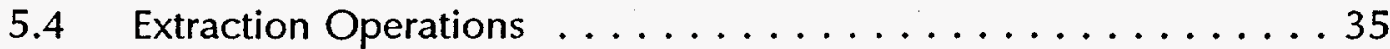

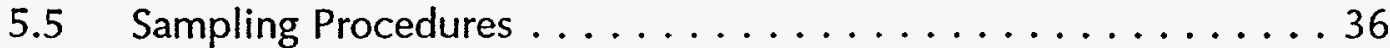

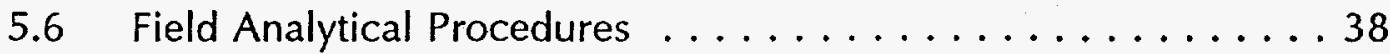

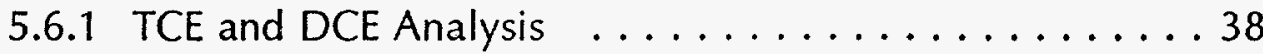

5.6 .2 Surfactant Analysis . . . . . . . . . . . . . . 39

5.6.3 Temperature Measurement . . . . . . . . . . . . 40 40

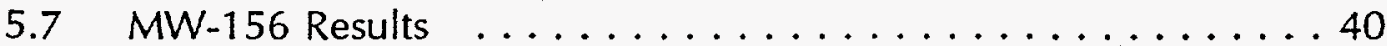

5.7 .1 TCE Concentrations . . . . . . . . . . . . 41

5.7.2 Surfactant Concentrations .............. 42

5.7 .3 Tc-99 Concentrations ................. . 43

5.7 .4 Temperature $\ldots \ldots \ldots \ldots \ldots \ldots \ldots \ldots \ldots \ldots \ldots \ldots$

5.7 .5 DCE Concentrations ................ . . 44

$5.8 \quad$ MW-155 Results . . . . . . . . . . . . . . 44

5.8.1 TCE Concentrations $\ldots \ldots \ldots \ldots . \ldots \ldots 4$

5.8 .2 Surfactant Concentrations .............. . 45

5.8.3 Dissolved Oxygen Concentrations, Temperature, and pH 46 


\section{Table of Contents}

(continued)

5.9 Simulation of Test $\ldots \ldots \ldots \ldots \ldots \ldots \ldots \ldots \ldots$

6.0 SUMMARY AND CONCLUSIONS $\ldots \ldots \ldots \ldots \ldots \ldots$

7.0 RECOMMENDATIONS ................... 50

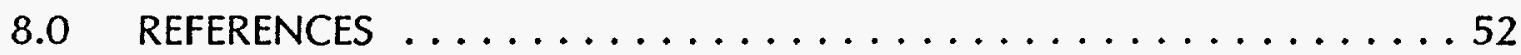

\section{List of Tables}

2.1 HLB Determination for TCE, PCE and CTET, Using Tergitol Series (Secondary Linear Alcohol Ethoxylates)

2.2 Solubilization Results for TCE, PCE and CTET in Nonionic Surfactants

2.3 Solubilization Results for TCE, PCE and CTET in Anionic Surfactants

2.4 Percent TCE and PCE Solubilized to Percent TCE and PCE in DNAPL Mixtures

2.5 Retardation Factors for Selected Surfactants

2.6 Interfacial Tension Measurements Between 1\% Surfactant Solutions and TCE, PCE, and CTET

2.7 Surfactant Critical Micellar Concentration

2.8 Surfactant Solution Viscosities

2.9 Surfactant Solubilization Kinetics

2.10 Solubilization Data for $1 \%$ Sorbitan Monooleate Solutions

2.11 Interfacial Tension (IFT) Measurements between 1\% Sorbitan Monooleate Solutions and TCE, PCE, or CTET

2.12 Viscosity of Sorbitan Monooleates (No. 18)

2.13 Retardation Factors for Sorbitan Monooleates 


\section{Table of Contents}

(continued)

\section{List of Tables (continued)}

3.1 Hydrostratigraphic data for MW-156 from Phillips (1992)

3.2 TCE Contamination in $\mathrm{mg} / \mathrm{L}$ in the WMU-11 Monitor Well Nest

3.3 Model Parameters

3.4 Comparison of Averaged Concentrations

5.1 Results of Field Analyses for MW-156

5.2 Precision Estimates for MW-156 Field TCE Analyses

5.3 Results of PGDP Analyses for MW-156

5.4 Matched-Pairs Analysis of Differences in Field and PGDP Results for MW-156

5.5 Results of Field Analyses for MW-155

5.6 Results of PGDP Analyses for MW-155

5.7 Matched-Pairs Analysis of Differences in Field and PGDP Results for MW-155

\section{List of Figures}

1.1 Schematic Showing the Migration of DNAPL in a Granular Aquifer System

1.2 Schematic Mechanism for Initial Solubilization

1.3 Location of Paducah Gaseous Diffusion Plant, Kentucky

2.1 Solubility vs HLB for TCE, PCE and CTET

3.1 Field Test Site Map

3.2 Hydrostratigraphic Section for MW-155 Showing Screened Interval for MW-156 


\section{Table of Contents (continued)}

\section{List of Figures (continued)}

3.3 Locations of Soils Borings near C-400 and the Cross Section F-G (from Phillips, 1992)

3.4 Hydrostratigraphy Along East Side of Building C-400 (from Phillips, 1992)

3.5 Conceptual Model of DNAPL Distribution in the Subsurface Beneath the C400 Building at PGDP (from Clausen et al., 1992)

3.6 Alternative Scenarios Simulated to Investigate Aqueous TCE Concentrations in the RGA

3.7 Stratigraphy and Location of Wells

3.8 Cross-Sectional Simulation Grid for Scenario A

3.9 Cross-Sectional Simulation Grid for Scenario B

3.10 Scenario A: Log of TCE Concentrations

3.11 Scenario B: Log of TCE Concentrations

4.1 PCE Desaturation Curves Following the Injection of Water and Surfactant Solutions into Soil Columns Containing Different Size Fractions of Ottawa Sand (after Abriola et al., 1993)

5.1 Injection Configuration

5.2 Extraction Configuration

5.3 Site Map Showing Work Zones

5.4 Surfactant Mixing and Retention System

5.5 Injection Phase, MW-156, August 5-9, 1994

5.6 Water Levels in Piezometer 109 During the Injection Phase, August 5-9, 1994

5.7 Extraction Phase, MW-156, August 9-25, 1994

5.8 Water Levels in Piezometer 109 During the Extraction Phase, August 9-25, 1994 


\section{Table of Contents}

(continued)

\section{List of Figures (continued)}

5.9 Plot of Precision Measurements for MW-156 Field TCE Analyses versus Mean TCE Concentrations

5.10 Plot of Results of Field Analyses for MW-156 versus Time

5.11 Plot of Results of PGDP Analyses for MW-156 versus Time

5.12 Plot of Sample Temperature for MW-156 versus Time

5.13 Plot of Approximate DCE Concentration in Several MW-156 Samples versus Time

5.14 Plot of Results of Field Analyses for MW-155 versus Time

5.15 Plot of Dissolved Oxygen Concentration for MW-155 versus Time

5.16 Plot of Sample Temperature for MW-155 versus Time

5.17 Plot of $\mathrm{pH}$ for $\mathrm{MW}-155$ versus Time

$5.18{ }^{99} \mathrm{TC}$ and TCE Response During Extraction Phase

5.19 Surfactant Recovery During Extraction Phase Compared to that of a Conservative Tracer

7.1 Schematic of Interwell NAPL Solubilization Test

7.2 TCE and Surfactant Concentrations at the Extraction Well

\section{List of Appendices:}
A. T-MAZ 80K Material Safety Data Sheet
B. Injection Data (Rates and Heads)
C. Extraction Data (Rates and Heads)
D. MW-156 Gas Chromatograph Data
E. Calibration, Precision, and Regression Statistics for Field Surfactant Analyses
F. MW-155 Gas Chromatograph Data 


\section{Acknowledgement}

INTERA Inc. is very grateful to the personnel of Martin Marietta Energy Systems, Inc. for their friendly collaboration and their tireless assistance with site characterization, waste-water treatment, and permitting, and during the field test. Special thanks are owed to Ken Davis and Jeff Douthitt for their effort, ideas, and enthusiasm. 


\section{Abstract}

Laboratory, numerical simulation, and field studies have been conducted to assess the potential use of micellar-surfactant solutions to solubilize chlorinated solvents contaminating sand and gravel aquifers. Laboratory studies were conducted at the State University of New York at Buffalo (SUNY) while numerical simulation and field work were undertaken by INTERA Inc. in collaboration with Martin Marietta Energy Systems Inc. at the Paducah Gaseous Diffusion Plant (PGDP) in Kentucky.

Ninety-nine surfactants were screened for their ability to solubilize trichloroethene (TCE), perchloroethylene (PCE), and carbon tetrachloride (CTET). Ten of these were capable of solubilizing TCE to concentrations greater than $15,000 \mathrm{mg} / \mathrm{L}$, compared to its aqueous solubility of $1,100 \mathrm{mg} / \mathrm{L}$. Four surfactants were identified as good solubilizers of all three chlorinated solvents. Of these, a secondary alcohol ethoxylate was the first choice for in situ testing because of its excellent solubilizing ability and its low propensity to sorb. However, this surfactant did not meet the Commonwealth of Kentucky's acceptance criteria. Consequently, it was decided to use a surfactant approved for use by the Food and Drug Administration as a foodgrade additive. As a $1 \%$ micellar-surfactant solution, this sorbitan monooleate has a solubilization capacity of $16,000 \mathrm{mg}$ TCE/L, but has a higher propensity to sorb to clays than has the alcohol ethoxylate.

Constraints beyond INTERA's control prevented the assessment of the potentially suitable surfactants in the laboratory with cores and ground waters from the site. These constraints, which could not be resolved before the field test, meant the surfactant solution had to be injected without laboratory testing of the surfactant's compatibility with the aquifer materials.

The field test was conducted in the alluvial aquifer which is located 20 to 30 meters beneath a vapor degreasing operation at PGDP. This aquifer has become contaminated with TCE due to leakage of perhaps 40,000 liters of TCE, which has generated a plume of dissolved TCE extending throughout an area of approximately 
$3 \mathrm{~km}^{2}$ in the aquifer. Most of the TCE is believed to be present in the overlying lacustrine deposits and in the aquifer itself as a dense, non-aqueous phase liquid, or DNAPL.

The objective of the field test was to assess the efficacy of the surfactant for in situ TCE solubilization. This involved the injection and subsequent extraction of the surfactant solution through a single well. The aqueous concentrations of TCE in this well have consistently been measured at 300 to $550 \mathrm{mg}$ TCE/L over a period of three years. Capillary and bond numbers were calculated and evaluated to confirm the improbability of mobilization of DNAPL due to the lowering of the interfacial tension by the surfactant solution. The injection phase lasted 3.75 days at 3.8 liters per minute $(1 \mathrm{gpm})$, while the extraction phase lasted 16 days at 3.8 liters per minute $(1 \mathrm{gpm})$. The extraction operation, which removed four times the injected volume, recovered only $34 \%$ of the surfactant, probably due to sorption, precipitation, or liquid crystal formation of the surfactant, or some combination of these processes. Due to this loss of surfactant in situ, there was no enhancement of aqueous TCE concentrations in the recovered ground waters. TCE behaved nonconservatively during the early stages of extraction, suggesting that it may have been sorbed to the immobilized surfactants.

Although the test demonstrated that sorbitan monooleate was unsuitable as a solubilizer in this aquifer, the single-well test was demonstrated to be a viable method for the in situ testing of surfactants or cosolvents prior to proceeding to full-scale remediation. It is probable that this result could have been identified in the SUNY laboratory beforehand and an alternative surfactant chosen and tested with core materials, had it been possible to transfer core off site.

It is recommended that (1) detailed core analyses to screen surfactants meeting the Commonwealth of Kentucky's acceptance criteria be conducted, (2) the field studies at C-400 planned by PGDP for next spring be complemented with computational studies of DNAPL migration to assist in the design of the drilling program, and (3) an inter-well DNAPL solubilization test be undertaken over a distance of at least 10 meters to test the efficacy of DNAPL solubilization by micellar surfactant solution. 


\subsection{INTRODUCTION}

\subsection{Surfactant-Enhanced Aquifer Remediation}

Dense, non-aqueous phase liquids or DNAPLs, in particular chlorinated solvents such as trichloroethene (TCE), pose an as-yet unresolved ground-water contamination problem at DOE facilities across the nation. Figure 1.1 shows the migration of DNAPL in a sand and gravel aquifer system and the development of a DNAPL zone, comprising several vertical fingers and horizontal pools. Also shown are two dissolved-phase plumes, one partially due to vapor migration to the water table, the other due solely to DNAPL dissolution beneath the water table. The mobility of DNAPLs in the subsurface, their low aqueous solubility, and the heterogeneity of typical aquifer systems combine to create conditions that inhibit rapid in situ remediation by traditional pump-and-treat methods. Thus, tens to hundreds of liters of DNAPL may require tens to hundreds of years to be dissolved by ground-water extraction (Johnson and Pankow, 1992).

Such long remediation times mean that short-term remediation target dates will not be met. The hazardous waste clean-up program presently being undertaken by the U.S. Department of Energy is committed to the decontamination of the Weapons Complex facilities in 30 years (i.e., by the year 2019). As Mackay and Cherry (1989) have noted about DNAPLs in general, ". . . very little success has been achieved in even locating the subsurface sources, let alone removing them." Thus, it is essential that methods be developed to permit the rapid location, characterization, and remediation of such DNAPL sources if DOE's deadline is to be met.

A particularly attractive approach to the characterization and remediation of DNAPL sites involves the use of surfactants to enhance the dissolution of DNAPLs by a process known as solubilization. Surfactant-enhanced aquifer remediation (SEAR) is the generic name given to the process of in situ DNAPL remediation employing micellar surfactant solutions (Jackson, 1993).

The mechanism of solubilization displayed by nonionic and anionic surfactants arises from the formation of micelles by the surfactant in aqueous solutions (Rosen, 1989). Surfactants, or surface-active solutes, have polar and nonpolar groups that exhibit hydrophilic and hydrophobic properties, respectively. At certain characteristic concentrations, surfactants exhibit marked changes in several physical and chemical properties, e.g., electrical conductivity, interfacial tension and detergency. The concentration of the surfactant at which these phenomena occur is known as the critical micelle concentration, or CMC. At this concentration, the polar and nonpolar 
groups become oriented such that they form colloidal clusters of molecules in solution. The clusters are characterized by the interfacing of the hydrophilic groups with the water molecules on the outside of the cluster, while the hydrophobic groups are arranged pointing toward the interior of the cluster.

At the CMC, aqueous solutions of surfactants show a greatly enhanced ability to dissolve compounds that are otherwise sparingly soluble in aqueous solution. The hydrophobic interior of the micelles creates a nonpolar environment in the center of the cell which is capable of accommodating nonpolar molecules, effectively bringing the contaminants into solution. This process of solubilization has been defined by Rosen (1989) as ". . . the spontaneous dissolving of a substance (solid, liquid, or gas) by reversible interaction with the micelles of a surfactant in activity of the solubilized material." Figure 1.2 shows a schematic interpretation of solubilization.

It is well known in the petroleum industry that extremely high effective aqueous solubilities for organic compounds can be obtained by lowering the interfacial tensions of oil/surfactant mixtures to values less than 0.1 dynes/cm (Lake, 1989). By this method, it is possible to mobilize and displace petroleum hydrocarbons as an "oil bank." However, when remediating contaminated sites, such mobilization of DNAPLs could well result in their vertical displacement through permeable windows in sedimentary aquitards and through fractures in rock, resulting in deeper contamination. This has necessitated a different approach for surfactant-enhanced aquifer remedation. The alternative approach seeks to maintain the interfacial tensions above $1 \mathrm{dyne} / \mathrm{cm}$ to minimize the possibility of vertical and horizontal mobilization while striving for maximum effective solubility. Fountain et al. (1991) demonstrate that dilute (1\%) surfactant solutions may have interfacial tensions exceeding $1 \mathrm{dyne} / \mathrm{cm}$ with respect to perchloroethylene (PCE) with a solubilization capacity of $1 \mathrm{~g}$ PCE / g surfactant, where the aqueous solubility of PCE is $0.0002 \mathrm{~g} \mathrm{PCE} / \mathrm{g}$ water.

\subsection{Objectives}

This project is composed of two phases and has the final objective of demonstrating SEAR as a practical remediation technology in sand and gravel aquifers with ground water contaminated by DNAPLs such as chlorinated solvents. The first phase of this project, Laboratory and Pilot Field Scale Testing, which is the subject of the work so far, had two specific objectives:

1. to identify surfactants or blends of surfactants in the laboratory that will efficiently extract PCE and TCE from a sand aquifer by micellar solubilization; and 
2. to test the efficacy of the surfactant or surfactant blend(s) to solubilize the DNAPLs, perchloroethylene (PCE) and trichloroethylene (TCE), in situ by injection and then withdrawal of a surfactant solution through an existing well within the sand aquifer at a government-owned contaminated site.

(The underlined parts reflect changes to these specific objectives proposed by INTERA in its Cost to Complete proposal of September 28, 1994, in order to remove inconsistencies between the specific objectives listed above and the tasks set out by the Morgantown Energy Technology Center (METC) in the Statement of Work.)

These specific objectives became tasks in the Phase 1 project. The task structure is as follows:

Task 1.1: Information required for the National Environmental Policy Act (NEPA);

Task 1.2: Laboratory experiments to identify and characterize surfactants and their solubilization activity;

Task 1.3: $\quad$ Single-well, injection-withdrawal test for DNAPL solubilization;

Task 1.4: Phase 1 topical report.

\subsection{Site Selection}

The Statement of Work prepared for this contract by METC indicated that the field work would be conducted at a government-owned plant. A number of issues arose which indicated that it would be advantageous to conduct the field test at the Paducah Gaseous Diffusion Plant [PGDP] in Kentucky (see Figure 1.3). Most important of these was the possibility that the test might be conducted in a shallow aquifer (20 to 30 feet deep) at the "Drop Test" site at PGDP, which had been used for drop-testing UF cylinders and at which site TCE had leaked into the subsurface. Because PGDP was already committed to characterizing the Drop Test site by drilling numerous boreholes into the shallow aquifer, there was a significant cost advantage to using a shallow contaminated aquifer system rather than a deeper one. The decision to conduct the field test at PGDP with Martin Marietta Energy Services was endorsed by Mr. Jeff Walker of EM-50 (Germantown, MD) during a telephone discussion on February 17, 1993. 
However, on December 3, 1993, after one full year of field testing at the Drop Test site, PGDP decided to abandon the site because it had become clear that the shallow formation was not the high permeability sand and gravel PGDP first thought it to be. Rather, analysis of a core sample from the Drop Test Site at the State University of New York at Buffalo (SUNY-Buffalo) indicated that it was a poorly sorted material composed of clays and silts $(10 \%)$, sands $(24 \%)$, and gravel $(63 \%)$. (Cores from the Drop Test Site could be shipped to Buffalo because they were not radioactively contaminated; this was not the case with the $\mathrm{C}-400$ cores.) This soil material had a hydraulic conductivity of much less than $0.001 \mathrm{~cm} / \mathrm{s}$, which is the minimum acceptable hydraulic conductivity for the Phase 1 test. In a ground-water system with a hydraulic conductivity of less than $0.001 \mathrm{~cm} / \mathrm{s}$, the period of surfactant injection would be of the order of months-not days-for the surfactant solution to migrate out 10 feet from the injection well, and an equally long period of extraction. Because the Statement of Work clearly indicated that the test should be in a sand aquifer and therefore only a week of field work had been budgeted, the Drop Test site was clearly unsuitable for use for this test (see Progress Report dated January 12, 1994, ISD 15).

A second site at PGDP, the C-400 site, was chosen because a particular well at the site (MW-156) had a sufficiently high hydraulic conductivity and had TCE concentrations greater than $100 \mathrm{mg} / \mathrm{L}$, which suggested a nearby TCE DNAPL zone. Thus, as the Statement of Work indicated, an existing well could be employed. Consequently, a Work Plan for this new site was prepared in January and February 1994.

\subsection{Scope Limitations}

Three issues arose prior to the test which affected the original scope of the field test. First, Sandia National Laboratories was not able to subcontract with INTERA to test the effectiveness of the surfactant in the laboratory. Second, Martin Marietta Energy Systems' policy prevented INTERA from having cores of the RGA sent to SUNY-Buffalo for testing with the surfactants deemed suitable for injection. Third, the original preferred surfactant for the field test did not meet the State of Kentucky's acceptance criteria. Because these issues affected testing the efficacy of micellar-surfactant solutions prior to injection, it is necessary to discuss their importance in the hope that they might be resolved before the commencement of Phase 2 .

\subsubsection{Difficulties in Contracting with Sandia National Laboratories}

The original Statement of Work (SOW) of the contract included provision for work to be undertaken at the Sandia National Laboratories. The proposed role of Sandia in the Phase 1 study was identified in paragraph 2 of Task 1.2 of the SOW. The tests at Sandia concerned laboratory-scale and bench-scale solubilization experiments 
employing single- and multiple-component DNAPLs with the surfactant blend identified by Dr. Fountain at the State University of New York at Buffalo (SUNY-Buffalo).

DOE Albuquerque and DOE/METC were unable to reach agreement on the issue of the permissibility of Sandia National Laboratories being a subcontractor to INTERA for this work (J. Harness, METC, personal communication). This disagreement was noted in each monthly progress report submitted by INTERA to METC, beginning with that of June 18, 1993 (ISD 8). Therefore INTERA recommended to DOE (see Cost-to-Complete Proposal dated September 28, 1994) that the Phase 1 SOW should be changed to reflect the fact that these tests cannot be included in the Contract. The inability of Sandia to assist in the assessment of the surfactant was a considerable disadvantage to the project.

\subsubsection{Difficulties in Transfer of RGA Cores to SUNY-Buffalo}

During 1993, when the focus of the field work was on the Drop Test site, PGDP sent a core to SUNY-Buffalo for use in surfactant screening and hydrogeological characterization of the HU2 formation (see Figure 3.2). During the spring of 1994, there were prolonged and ultimately unsuccessful discussions between Martin Marietta Energy Systems at Oak Ridge, SUNY-Buffalo, DOE/METC, and INTERA over the shipping of a second core to SUNY for testing with surfactants which appeared to be suitable for employment in the RGA (HU4-5). This second core was to be taken from the PGDP core archives representing aquifer materials from the RGA near MW-156.

The difficulty in transferring this second core appears to have arisen from the presence of alpha and beta emitters in the aquifer samples (gross alpha $=3-5 \mathrm{pCi} / \mathrm{g}$; gross beta $=6-10 \mathrm{pCi} / \mathrm{g})$. The alpha emitters might include $\mathrm{U}, \mathrm{Pu}$, or other actinides, while the beta emitter would likely be ${ }^{99} \mathrm{Tc}$. Lawyers for Martin at Oak Ridge wrote SUNY. Buffalo requesting changes to SUNY's Radioactive Materials License to allow for (1) the presence of tritium in these samples, (2) an extension of the license to include elements with atomic numbers 84 through 98 (i.e., the actinide series, radium etc.) and (3) concentrations of up to $100 \mathrm{mCi}$ for isotopes with atomic numbers 84 to 98 . SUNY responded that tritium was already covered and that the requirement for a $100 \mathrm{mCi}$ quantity of each radioisotope with atomic number 84 to 98 was unreasonable in the light of the measured contamination, but that SUNY nevertheless was willing to explore changes to its license. Unfortunately, these changes could not be implemented before the test was undertaken in August 1994.

PGDP assisted in determining the nature of the aquifer materials by submitting a sample to the Oak Ridge National Laboratory for $x$-ray diffraction analysis. This testing 
revealed that more than $90 \%$ of the clay-sized fraction of this sample $(\sim 0.7 \%$ of the total sample, i.e., boring $\mathrm{H007}, 63-69 \mathrm{ft}$, sample \#4382) was composed of quartz, with lesser amounts of kaolinite, smectite and hematite (memorandum from Dr. Mark Elless, Oak Ridge National Laboratory, to K.R. Davis, PGDP, dated 2.18.94). Therefore, it appears probable that the total concentration of smectite, an expandable clay mineral which could readily sorb surfactants, would be about $0.02 \%$ of the total sample. Such a concentration would be unlikely to exert a pronounced negative effect on surfactant injection within the RGA.

\subsubsection{Difficulties with Employment of the Preferred Surfactant}

On March 24, PGDP and INTERA made a presentation to the Division of Waste Management, Environmental Protection Cabinet, of the Commonwealth of Kentucky concerning the proposed field test. The state representatives agreed to allow the test to go forward provided that:

1. additional scoping calculations were made using higher hydraulic conductivities in estimating the bond number (see Section 4) than had been used initially by INTERA; and

2. an alternative surfactant be chosen which did not contain reagent chemicals prohibited in Kentucky ground waters (Tergitol, an alcohol ethoxylate, contains unreacted reagent chemicals such as 1,4-dioxane and glycol ether which are prohibited in Kentucky ground waters).

Tergitol had been shown to perform excellently during the in situ solubilization of carbon tetrachloride at the DuPont chlorocarbon facility near Corpus Christi, Texas, by Dr. John Fountain of SUNY-Buffalo (Fountain, 1993). Tergitol was replaced with a sorbitan monooleate surfactant (T-MAZ 80K) which had sorbed appreciably during the Corpus Christi test but was chosen on the basis of the expected low clay content of the RGA and its FDA-approved status as a food-grade additive with good biodegradation properties and very low toxicity.

Later, the state of Kentucky indicated to PGDP that it would like to see the majority of the surfactant recovered. Consequently, by agreement with PGDP, the extraction period was lengthened to four times the injection period. This resulted in the length of the field test being extended from 49 man-days in the proposal to 90 days in the field, adding considerably to the cost of the field test. Final approval to conduct the field test was granted by the Commonwealth of Kentucky in June (letter of Caroline Haight, June 3, 1994). 


\subsection{LABORATORY EXPERIMENTS TO IDENTIFY AND CHARACTERIZE SURFACTANTS AND THEIR SOLUBILIZATION ACTIVITY}

A significant factor in selecting a surfactant for the field test is its ability to solubilize TCE, PCE, and CTET. Toxicity, sorption, interfacial tension, and viscosity must also be evaluated before a final selection can be made. The following sections detail the analyses performed by SUNY to determine an appropriate surfactant for the C-400 site at PGDP.

\subsection{Aquifer Characterization}

Aquifer characterization data is critical in the selection of an appropriate surfactant for the field test. Grain size distribution, clay chemistry, and total organic carbon content determine the sorption of the surfactant to the soils (see Section 2.4). A knowledge of site water chemistry is critical because many surfactants are intolerant of high cation concentrations. No samples were made available to SUNY for characterization of the aquifer sediments or water from the C-400 site; therefore, no core characterization studies could be conducted. As a result, several assumptions had to be made to assure a reasonable choice of surfactants. Surfactant sorption is proportional to the smectite clay content and total organic carbon (TOC) content. Clay percentages have been reported to be considerably less than $1 \%$, so clay adsorption was not expected to be significant. Because this aquifer is well below the surface, it was reasonable to assume that TOC values will be low and thus sorption will also be low. Because the water chemistry was unknown, the selected surfactant must be tolerant of a wide range of conditions to minimize potential problems resulting from variations in aquifer, soil, and water chemistry.

\subsection{Solubilization}

Examination of solubilization results for TCE, PCE (perchloroethylene), and CTET (carbon tetrachloride) suggest that sorbitan derivatives, ethoxylated amide derivatives, secondary alcohol ethoxylates, castor oil derivatives, and alkylaryl sulfonate derivatives are the best solubilizers. The results and experiments are discussed in detail below.

\subsubsection{HLB Determination}

Any organic liquid, such as a surfactant or a chlorinated solvent, can be ascribed an HLB number, i.e., a hydrophilic-lipophilic balance number. In order to form a microemulsion of a chlorinated solvent in a surfactant solution, it is best to match the HLB number of the surfactant solution with the HLB number of the chlorinated solvent. 
Therefore, an initial task was to identify the HLBs of the three chlorinated solvents of concern: TCE, PCE, and CTET. Knowing these values, potentially suitable surfactants could be identified from previously reported values.

The HLB was determined for TCE, PCE, and CTET using the Tergitol secondary alcohol ethoxylates by gas chromatograph (GC) analysis of surfactant contaminant mixtures. Solutions of $25 \mathrm{ml}$ of $1 \%$ surfactant in distilled water plus excess $(>0.5 \mathrm{ml})$ TCE, PCE or CTET were prepared and stirred for a minimum of 24 hours. The TCE was dyed red with Sudan IV to enhance visibility. The solutions were then centrifuged at 3,500 rpm for one hour and analyzed.

The Tergitol with the highest solubilized concentration represents the HLB of the contaminant. An HLB of 14.7 was determined for TCE and CTET, and an HLB of 13.3 for PCE (see Table 2.1 and Figure 2.1). Once the HLB was established, quantitative gas chromatograph (GC) screening $f$ nonionic and anionic surfactants was undertaken.

\subsubsection{Solubilization of TCE}

The ability of a $1 \%$ surfactant solution to solubilize TCE was determined by GC analysis of surfactant contaminant mixtures using a test parameter known as the maximum additive concentration (MAC). The MAC represents the maximum concentration of TCE or other contaminant which can be solubilized by a given volume. To determine the MAC, $25 \mathrm{ml}$ solutions of $1 \%$ surfactant in distilled water plus excess $(0.5 \mathrm{ml})$ TCE were prepared and stirred for a minimum of 24 hours. The TCE was dyed red with Sudan IV to enhance visibility. The solutions were then centrifuged at 3,500 rpm for one hour and analyzed. Additional volumes of TCE were added, stirred, and analyzed until a limit was achieved above which solubilization no longer occurred-the MAC. Initial screening of nonionic surfactants proceeded using $1 \%$ solutions of surfactants with HLBs ranging from 14 to 17 . A total of 99 surfactants was screened, including 25 nonionics and 74 anionics (see Tables 2.2 and 2.3). The results are discussed below.

Examination of the data indicates that 10 of the 99 surfactants tested to date solubilize TCE at greater than 15,000 ppm (5 nonionics, 5 anionics) (see Tables 2.2 and 2.3). Among the nonionics, sorbitan monooleates and castor oil derivatives are the most promising, since they are food grade additives and have high solubilization values $(>16,000 \mathrm{ppm})$. In addition, the soya sterol, with a solubilization value of about $29,000 \mathrm{ppm}$, is also promising. Within the anionics, alkylaryl sulfonates, sulfonate/nonionic blends, and phosphate esters show the best solubilization $(>15,000 \mathrm{ppm})$. Castor oil sulfates and sulfonates are also good solubilizers, with solubilities ranging from $10,000 \mathrm{ppm}$ to approximately $15,000 \mathrm{ppm}$. 


\subsubsection{Solubilization of Other Contaminants}

In addition to TCE, PCE and CTET are other contaminants of concern. To determine if the other contaminants could be remediated efficiently using the same surfactants, $25 \mathrm{ml}$ solutions of $1 \%$ surfactant plus $0.5 \mathrm{ml}$ of PCE or CTET were prepared for GC analysis. The solutions were stirred for a minimum of two days and then centrifuged at 3,500 rpm for one hour before analysis.

Examination of the data indicates that the surfactants that are good solubilizers of TCE will also solubilize the PCE and CTET. Generally, PCE solubilizes less than TCE and the solubility of CTET showed more variation (see Tables 2.2 and 2.3). For example, the solubilization of TCE in the sorbitan derivatives is generally greater than 13,000 $\mathrm{ppm}$, whereas the solubilization of PCE is generally less than $6,000 \mathrm{ppm}$ and the solubilization for CTET ranged from 10,500 to $12,500 \mathrm{ppm}$. Four surfactants are good general solubilizers of all contaminants. These are no. 60 (a Sorbitan monooleate), no. 119 (an Alkylaryl sulfonate isopropylamine), no. 135 (C11-C15 secondary alcohol ethoxylate) and no. 154 (POE 7 Oleamide).

Comparison of the MAC to aqueous solubility of the various contaminants suggests that the increase in solubility of the contaminant is a function of the aqueous solubility. PCE with a solubility of $150 \mathrm{ppm}$ attains 135 times the aqueous solubility. TCE with a solubility of $1,100 \mathrm{ppm}$ attains a maximum of 23 times aqueous solubility.

\subsubsection{Solubilization of Mixtures}

Most of the tests were done using one component DNAPLs (TCE or PCE) because it eliminates possible complications arising from their interaction; however, mixtures are more typical of actual DNAPL contamination found in the field. To study whether cosolvent effects (i.e., the enhancement of DNAPL solubility due to the presence of dissolved components of another DNAPL) occur between the components of a DNAPL mixture, mixtures of PCE and TCE were prepared in the following proportions (TCE:PCE) for each surfactant under consideration (\#18, \#135, and \#154): 90:10, 75:25, 50:50, and 25:75 (see Table 2.4).

Examination of the results indicates that the percent of TCE and PCE solubilized is approximately equal to the percent of TCE and PCE present in the DNAPL mixture. This indicates that co-solvent effects are insignificant. 


\subsection{Toxicity}

The toxicity of any compound that will be injected into water-bearing zones is of concern since remediation is supposed to solve contamination problems, not exacerbate them. The surfactants under consideration are either food grade additives or food usage additives, which means that small amounts are not toxic. Surfactants in general have very low toxicity to mammals. Their LD50s (lethal dosage at which 50 percent of test animals are killed) are in the same range as sodium chloride (Swisher, 1987). Several types of surfactants, including many of the sorbitan derivatives (i.e. surfactants nos. 18,60,64 and 161) and the sodium lauryl sulfate are classified as food grade additives by the FDA (CFR 21.172). Many others are classified as suitable for use on food and food processing equipment, including the alcohol ethoxylates. like surfactant no. 135. One major use of surfactants is in dish-washing soaps; thus, it is likely that small amounts of surfactants are ingested regularly by large segments of the population. Surfactants, however, have higher toxicities to aquatic life and thus the discharge levels to fresh water must be regulated.

All the surfactants currently under consideration are non-toxic to humans, especially at concentrations of $1 \%$ or $2 \%$.

\subsection{Sorption}

Sorption refers to the combination of adsorption and absorption since they can seldom be independently evaluated in ground-water systems. Because surfactants are organic compounds, their sorption on clay and organic aquifer materials may be significant and thus may be an important factor in determining the cost of remediation. Sorption isotherms are typically Langmuirian with a steep slope prior to the critical micellar concentration (CMC) and then a nearly flat slope above the CMC. The shape of the isotherm has been explained by two different models: (1) the site model, and (2) the micelle model. The site model is a conventional interpretation in which it is assumed that by the time the CMC is reached, all sites on the surface have received a mono layer of surfactants. Sorption is minimal above this point. The micelle model is based on the distribution of surfactants in the aqueous phase. Below the CMC, surfactant molecules are present as monomers; their concentration in the aqueous phase is the same as the total surfactant concentration up to the CMC. Above the concentrations where micelles form, the concentration of the monomers remains at the CMC concentration. Any additional surfactant added to the system forms micelles and thus the aqueous monomer phase concentration does not change. Since micelles are not believed to be sorbed (they have strongly polar outer shells), sorption is controlled by 
the monomer concentration up to the $\mathrm{CMC}$ and is flat above it as the monomer concentration stays constant. Data are consistent with either model.

Sorption varies with mineralogy of the aquifer, organic content, and water chemistry. In the target zone, there was assumed to be little organic carbon and minor amounts of smectitic clays ( $<1 \%$ reported; see Section 1.4 .2$)$. It is highly probable that these smectites control the sorption of the surfactants. Because smectite clays have large surface areas (Grim, 1968), surfactants as surface active agents should be expected to react strongly with them. Thus, in the presence of these clays, it is expected their percentage controls the sorption of the surfactants. Examination of sorption on smectite-rich sediments suggest that this is true. In fact, sorption in these soils is considerably higher than sorption on $3 \%$ organic soils tested in our laboratory. The results of the batch tests are discussed below.

\subsubsection{Batch Tests}

The clay mineralogy of the core sample received in September 1993 for the Drop Test site indicated that there was a maximum of $3 \%$ interlayered illite/smectite clay, with approximately $50 \%$ of the clay being smectites. Based on these data, batch tests were prepared using a mixture of $3 \%$ illite/smectite clay ( $40 \%$ smectite) and $97 \%$ sand for the following four surfactants:

- no. 60 (Sorbitan monooleate)

- no. 119 (Alkylaryl sulfonate isopropylamine)

- no. 135 (C11-C15 secondary alcohol ethoxylate)

- no. 154 (POE 7 oleamide).

Eight grams of soil were added to $40 \mathrm{ml}$ of $1 \%$ surfactant prepared in water with a total dissolved solid content of $2,612 \mathrm{mg} / \mathrm{L}$. The flasks were shaken for 24 hours to ensure that equilibrium had been reached. The solutions were then analyzed using either UV analysis or the cobalt thiocyanate dye method for nonionics (Greff et al., 1965). The difference between the initial and final concentrations of surfactant were used to calculate the retardation factor. The retardation factor $(R)$ is a ratio of the velocity of water through a soil system to the velocity of a solute (such as a surfactant) through the same system. This ratio is a function of the sorption of the compound on the soil. Examination of the data suggests all surfactants under consideration have retardation factors lower than 5 in $3 \%$ clay soils with brackish water (see Table 2.5). Surfactant no. 119 was not tested because the solution was cloudy, making it unsuitable for use. 
Subsequent analysis of similar aquifer material from borehole $\mathrm{H} 007$ (see Figure 3.1 for location) by Oak Ridge Laboratories indicates that there is only $0.02 \%$ clay in the target formation. Retardation decreases with decreasing clay (see Table 2.5) and thus the actual retardation values should be less than 2 , making them acceptable for use.

In addition, the batch studies were conducted using water with a total dissolved solid content (TDS) of $2,612 \mathrm{mg} / \mathrm{L}$, which is considered brackish water (Freeze and Cherry, 1979). Although the ground water in the Paducah aquifer is expected to be fresh water, no site water analyses were available to us and thus this composition represents a probable upper limit. Many surfactants are sensitive to ionic strength, and using brackish water ensures that the chosen surfactant will be tolerant of a wide range of water chemistry.

\subsection{Surfactant Physical Properties}

The physical properties of surfactant solutions, such as interfacial tension, critical micellar concentration, and viscosity affect their transport through the subsurface and their ability to solubilize contaminants. The interfacial tension between the surfactant and the contaminant determines whether the contaminant will be mobilized horizontally or vertically during surfactant flushing. The critical micellar concentration determines the point at which a surfactant can solubilize the contaminant through the formation of micelles. The solutions used during remediation must exceed this concentration to maximize contaminant solubilization. The viscosity of the surfactant solution partly determines whether it can flow easily through the subsurface. Examination of these properties suggests that surfactants nos. 18, 135, and 154 are viable for use at Paducah.

\subsubsection{Interfacial Tension}

Surfactants have the ability to lower the interfacial tension of the DNAPLs by several orders of magnitude, which in theory would allow horizontal movement of the DNAPL through traction of pumped ground water. However, reducing the interfacial tension of the contaminant sufficiently to mobilize the contaminant horizontally may also induce unwanted vertical mobility (Fountain, 1992; Palmer and Fish, 1992), making the task of DNAPL retrieval that much more difficult. Laboratory and field tests suggest that no vertical movement occurs if the IFT is at least 1 dyne/cm.

The IFT between TCE, PCE, and CTET and several $1 \%$ surfactant solutions were measured (see Table 2.6). Obtaining IFT values between TCE and the surfactant solutions proved to be problematic because emulsions formed on the interface, leading 
to apparently elevated IFT values. However, comparison of IFT values between the surfactant solutions and the DNAPL compounds where emulsions did not form suggests that IFT values between the surfactant solutions and TCE should be similar to IFT values between the surfactant solutions and PCE or CTET. Thus, IFT values between a particular surfactant solution and TCE can be estimated from the IFT values between the surfactant solution and PCE or CTET. Using such an estimation, a $1 \%$ solution of surfactant no. 135, for example, has an IFT with TCE of between 5 and 7 dynes $/ \mathrm{cm}$. Examination of the results suggests that most of the surfactant types of interest at $1 \%$ solution have IFTs greater than $1 \mathrm{dyne} / \mathrm{cm}$ with respect to TCE, PCE, and CTET, and may be suitable for use.

\subsubsection{Critical Micellar Concentration}

Determination of the critical micellar concentration (CMC) is essential to the determination of the percent surfactant that can be used in the field test. The CMC value represents the minimum volume percentage of surfactant that can be used in solution and maintain the micellar structure necessary for contaminant solubilization. The CMC for surfactant no. 135 (linear alcohol ethoxylate) is reported as $0.011 \%$, and for surfactant no. 18 (sorbitan monooleate) it is $0.012 \%$ (PPG Corporation communication to R.E. Jackson). Surface tension measurements confirm that the critical micellar concentration is considerably less than $1 \%$ for both surfactants (see Table 2.7). Thus, use of a minimum of a $1 \%$ surfactant solution ensures the presence of micelles during remediation.

\subsubsection{Viscosity}

Viscosity measurements were made on $1 \%$ and $2 \%$ solutions of surfactants nos. 18 , 135 , and 154 to ensure that the solutions have a low enough viscosity to permit movement through the aquifer. Examination of the data indicates that the viscosity of the $1 \%$ and $2 \%$ solutions is similar to that of water (see Table 2.8 ) and thus the solutions should flow at approximately the same rate as the ground water.

\subsection{Solubilization Kinetics}

Column studies were conducted to determine the relative solubilization kinetics between TCE and surfactants nos. 18, 135, and 154. The maximum concentration obtained and the number of pore volumes required to reach the maximum concentration were used to measure the solubilization kinetics between the contaminant and the surfactant. 
Examination of the data in Table 2.9 suggests that, of the three target surfactants, no. 18 exhibits the best kinetics. It produced effluent containing 13,600 ppm of dissolved TCE within one pore volume, which is $84 \%$ of the MAC determined in vial tests (@ 16,000 ppm). Surfactant 154 reached 10,000 ppm TCE after 1 pore volume, which is $55 \%$ of the vial MAC (@18,000 ppm). Surfactant 135 had a thick layer of emulsion at the base of the column and there appeared to be some drainage of TCE from the column. Number 135 only attained 3,111 ppm after several pore volumes, which is only $24 \%$ of the vial MAC (@ 13,000 ppm). There are several possible reasons for this. The mobilization of the TCE to the bottom of the column may have resulted in reduced contact time and area for the surfactant, which would lead to lower solubilization. In addition, the presence of an immobile emulsion may have inhibited the solubilization process.

\subsection{Surfactant Selection}

The solubilization data suggest that the following surfactants have solubilization values that exceed 10,000 ppm for TCE and are thus possible candidates for use in the field test:

$$
\text { Surfactant No. } \begin{aligned}
18 & =\text { POE20 Sorbitan Monooleate } \\
119 & =\text { Alkyl Aryl Sulfonate Isopropylamine } \\
121 & =\text { PEG } 25 \text { Soya Sterol } \\
128 & =\text { Aliphatic Phosphate Ester } \\
135 & =\text { C11-C15 Secondary Alcohol } \\
154 & =\text { POE } 7 \text { Oleamide } \\
213 & =\text { PEG } 1100 \text { Castor Oil } \\
249 & =\text { Na Sulfated Ester } \\
250 & =\text { Sulfated Castor Oil } \\
271 & =12 \text { POE Nonylphenol }
\end{aligned}
$$

Examination of the scrption and toxicity data suggested that the best choice for the Paducah field test was a secondary alcohol ethoxylate (surfactant no. 135, commercial name: Tergitol 15-S-12). However, this surfactant proved unsatisfactory to the Commonwealth of Kentucky because of the possibility of its containing unreacted reagent chemicals which are prohibited in Kentucky ground waters. The second choice for the surfactant was a sorbitan monooleate (surfactant no. 18, commercial name: T-MAZ-80). It combines excellent solubilization ability with extremely low toxicity but can have a problem with sorption if the soils contain clays and organic materials. Tables 2.10 through 2.13 summarize the solubilization, IFT, viscosity and retardation factor data for surfactant no. 18 and the other sorbitan monooleates in the study. 
Surfactant no. 18 increases TCE solubility to approximately $16,000 \mathrm{ppm}$ in a $1 \%$ surfactant solution from an aqueous solubility for TCE of $1,100 \mathrm{ppm}$ (see Table 2.10). Table 2.11 shows the interfacial tension between a $1 \%$ solution of surfactant no. 18 and TCE is 11.67 dynes $/ \mathrm{cm}$ which is an order of magnitude greater than the 1 dyne/cm cut-off used in the study. Viscosity measurements made on $1 \%$ and $2 \%$ solutions of surfactant no. 18 are similar to that of water (see Table 2.12). It is a better performer than Tergitol 15-S-12 (surfactant no. 135) in these respects. It is also tolerant of a wide range of water chemistries ranging from brines to fresh water. It was not initially recommended because its sorption is higher than Tergitol; however, studies indicate that the sorption remains low on sediments if clay and organic contents remain low (see Table 2.13). If the characterization data supplied to SUNY is correct and the clay content is indeed below $1 \%$, sorption should be minimal. Analysis of sorbitan monooleate concentration in solution is also easy, since it may be measured directly by UV adsorption. It is a chromophore, so no dye is required. Finally, the deciding factor in view of the objections raised to Tergitol by the State regulators (see Section 1.4.3), sorbitan monooleates are food grade additives as per CFR 21.172.840 and thus have very low toxicity and high biodegradability.

Surfactant no. 154 was our first alternate. It is a good general solubilizer and is tolerant of a wide range of water chemistry. Its sorption should be low if clay contents are < $1 \%$ and it has low toxicity.

The remaining surfactants are unlikely candidates for a variety of reasons. The soya sterol (no. 121) was eliminated because it is a specialty surfactant and its cost is prohibitive. Surfactants no. 119, 213, 249, and 250 precipitate in ground waters with high ionic strengths making them unsuitable for use where water chemistry is unknown. Nonylphenol ethoxylate (surfactant no. 271) may persist for extended periods in the subsurface due to low biodegradability, making them unsuitable for remediation efforts. Phosphate esters such as surfactant no. 128 hydrolyze rapidly, making them unsuitable. 


\subsection{THE FIELD TEST SITE}

\subsection{Contaminant Hydrogeology of WMU-11}

The field test site is known as Waste Management Unit 11 (WMU-11) and is centered on monitor well MW-156, which is located at the southwestern edge of Building C-400 (Figure 3.1). Large volumes of TCE were used in C-400 to degrease electrical equipment. During an excavation in 1986, it was discovered that substantial amounts of TCE had escaped into the subsurface through a broken connection between the C400 sump line and a concrete sewer. Estimates reported by Clausen et al. (1992) indicate that some 10,000 gallons $(40,000 \mathrm{~L})$ of TCE may have leaked through the broken connection. MW-156 is one of a nest of monitor wells installed at WMU-11 to monitor the concentrations of TCE in the ground-water zone beneath Building C400 .

The hydrostratigrahic profile for MW-155, which is adjacent to and somewhat deeper than MW-156, is shown in Figure 3.2 and summarized in Table 3.1. The well screen for MW-156 is plotted on Figure 3.2 and indicates that it is screened over a distance of $2 \mathrm{~m}$ at 19 to $21 \mathrm{~m}$ ( $63 \mathrm{to} 70 \mathrm{ft}$ ) below grade in a zone of gravelly, fine to medium sand. A mean hydraulic conductivity equal to $3 \times 10^{-3} \mathrm{~cm} / \mathrm{s}$ has been measured by $\mathrm{CH} 2 \mathrm{M}$ Hill (1992). The sand pack for MW-156 extends over $4 \mathrm{~m}$ from 18.5 to $22.5 \mathrm{~m}$ ( 61 to $75 \mathrm{ft}$ ) below grade. MW-155 monitors the lower part of the Regional Gravel Aquifer (RGA or HU5) and has a measured hydraulic conductivity of $4.4 \times 10^{-3} \mathrm{~cm} / \mathrm{s}$. MW-156 monitors the upper part of the RGA, while MW-157 is screened in HU2 and has a measured hydraulic conductivity of $2.5 \times 10^{-5} \mathrm{~cm} / \mathrm{s}$. Beneath the RGA is the McNairy formation, which, according to the MW-155 borehole log, is composed of sandy clay that would act as a capillary barrier to penetration of the TCE DNAPL.

The hydrostratigraphy of the surficial sediments beneath C-400 has been analyzed by Phillips (1992) using a number of boreholes (shown in Figure 3.3) together with cross section F-G. The hydrostratigraphic model along the cross section of the subsurface beneath $\mathrm{C}-400$ is shown in Figure 3.4. The basal MCNairy formation is overlain by the RGA, which appears to fine upwards. However, the hydraulic conductivities of MW155 and $M W-156$, as determined by slug testing, are similar, which suggests that fineand medium-grained sands are abundant within the RGA and dictate the measured hydraulic and capillary properties. The lacustrine deposits above the RGA contain interbeds of sand and gravel which may provide part of the vertical pathway for DNAPL migration, although PGDP staff have noted fractures in these deposits which provide a more plausible and direct pathway to the RGA. 
Clausen et al. (1992) have presented a conceptual model of DNAPL distribution beneath C -400 which is reproduced as Figure 3.5. The concentrations of TCE observed beneath WMU-11 are shown in Table 3.2. They indicate significant contamination to the bottom of the RGA. However, both HU 2 and the upper RGA are especially contaminated. The level of contamination in these two zones, being greater than $10 \%$ of the aqueous solubility of TCE, is strongly indicative of the presence of TCE DNAPL zones (EPA, 1992) surrounding the wells. This zone probably is comprised of vertical fingers and horizontal pools of TCE, as shown in Figures 1.1 and 3.5, with the pools perched on capillary barriers and containing large amounts of residual DNAPL and, possibly, some free-phrase TCE. Monitor wells indicate that the RGA is also contaminated with some PCE, indicating that the DNAPL is a multicomponent mixture.

\subsection{Scenarios of TCE in the Regional Gravel Aquifer}

The conceptual model of DNAPL migration beneath C-400 shown in Figure 3.5 appears to be derived from that proposed by Kueper (1991) in a review of the C-400 DNAPL problem. He noted that:

The volumes of DNAPL released at PGDP have the potential to migrate to significant depths below ground surface. The ultimate depth of penetration is dependent upon many factors, most of which cannot be practically determined.

Kueper concluded that ". . . it must be assumed that DNAPL has entered the MCNairy formation unless it can be proven otherwise," and that DNAPL may be pooled in the RGA above the McNairy.

This does not appear to be the case at the C-400 site. Assuming that the McNairy is indeed a sandy clay as the MW-155 log indicates, the entry of DNAPL into the MCNairy would require a DNAPL pool height of at least 4 meters, assuming (very conservatively) a maximum pore throat radius of the sandy clay of $1 \mu \mathrm{m}$ and a TCE/ground-water interfacial tension of 10 dynes $/ \mathrm{cm}(0.01 \mathrm{~N} / \mathrm{m})$. Such a pool would inevitably manifest its presence as free-phase TCE in MW-155. As it is, MW-155, at the base of the RGA, exhibits aqueous TCE concentrations of $2 \mathrm{mg}$ TCE/L, which is too low to allow the nearby presence of substantial amounts of residual TCE DNAPL, let alone a pool of such thickness.

A scenario similar to that of Kueper's was described by McConnell et al. (1994) based on numerical simulation of the C-400 TCE release. McConnell et al. concluded that "... residual TCE in the RGA averages about $5 \%$ and is fairly uniform; however, a 
large pool of TCE which is only a few centimeters thick is formed at the RGA-MCNairy interface." Similar objections must be made to this scenario as to that of Kueper.

Figure 3.6 shows a schematic of the subsurface beneath C-400 which assumes that the pathway of ground-water recharge and DNAPL migration to the RGA is via a network of interconnected fractures. This aspect of the scenario is consistent with the observations made at the nearby PGDP landfill of deep fractures in the silts and clays extending all the way through the Upper Continental Deposits to the top of the RGA (Clausen et al., 1992, p.106) and with the measurement of dissolved oxygen and below neutral pH in MW-155 ground-water samples (see Section 5.8).

Scenario A of Figure 3.6 shows the distribution of TCE DNAPL within the RGA as a zone located upgradient of MW-156 and limited to the upper RGA. Scenario $B$ in Figure 3.6 is that predicted by McConnell et al. (1994). These two scenarios have been simulated using INTERA's version of the UTCHEM multiphase, multicomponent simulator developed by G.A. Pope, K. Sepehrnoori, and colleagues of the Department of Petroleum and Geosystems Engineering of the University of Texas at Austin.

\subsection{Simulation of TCE Scenarios in the Regional Gravel Aquifer}

All the scenarios in this section were performed using UTCHEM (the University of Texas Chemical Flood Simulator (Saad, 1989)) a three-dimensional, multi-phase, multicomponent, finite difference simulator originally designed to model enhanced-oil recovery.

Two scenarios were modeled in an effort to match the aqueous TCE concentration data in MW-155, 156, and 178. Both involved an area of residual TCE saturation that was allowed to dissolve into the surrounding water until steady state was achieved. Figure 3.7 is a schematic of the cross section that was simulated in both scenarios. The only differences between the two scenarios are the location of the DNAPL source and the size of the grid blocks. The cross section consists of four different stratigraphic layers representing the ground-water zone beneath building C-400 in the vicinity of wells MW-155, 156 and 178. The cross section has a length of $229 \mathrm{~m}(750 \mathrm{ft})$ and a

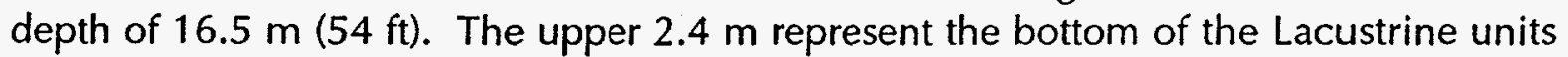
consisting of sandy clay. The next $5.5 \mathrm{~m}$ represent the upper half of the RGA consisting of sand. The next $6.1 \mathrm{~m}$ (20 ft) represent the bottom half of the RGA consisting of

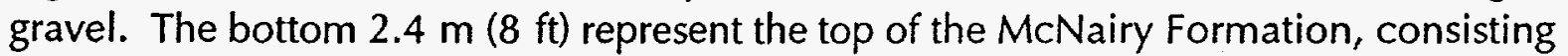
of sandy clay. Three $5-\mathrm{cm}$ (2-inch) diameter wells are completed within this cross section: $M W-155,156$, and 178. The first well, $M W-156$, is screened from -19.2 to $-21.3 \mathrm{~m}(-62$ to $-70 \mathrm{ft})$. The next well, $\mathrm{MW}-155$, located $9 \mathrm{~m}$ to the north, is screened 
from -26 to $-28 \mathrm{~m}$ ( -86 to $-92 \mathrm{ft})$. The final well, $\mathrm{MW}-178$, located $64 \mathrm{~m}$ to the north, is screened from -18.9 to $-20.7 \mathrm{~m}(-62$ to $-68 \mathrm{ft})$. The locations of these wells are shown on Figure 3.3. The DNAPL source for Scenario $A$ is represented by the dark horizontal rectangle within the cross section. Its center is located $27.4 \mathrm{~m} \mathrm{(90} \mathrm{ft)} \mathrm{south}$ of the first well and just within the Upper RGA. Its length is $27.4 \mathrm{~m}$ and its height was $0.6 \mathrm{~m}$. This source consists of DNAPL at a residual saturation of 0.15 (i.e., $15 \%$ of the pore space is occupied by TCE DNAPL), which means there are 268 liters ( 71 gallons) of TCE present in this DNAPL zone. The DNAPL source for Scenario B is represented by the dark vertical rectangle at the south of the schematic. Its center is located 45.7 $\mathrm{m}$ south of the first well and spans the entire RGA. All blocks within this source are at 0.05 residual saturation TCE DNAPL, except for the bottom one, representing a pool $7.6 \mathrm{~cm}$ high, with a residual saturation of 0.40 , containing 591 liters (156 gallons) of TCE. This scenario is similar to that of McConnell et al. (1994).

The $25 \times 27$ block simulation grid for Scenario A is shown in Figure 3.8. The $25 \times 32$ block simulation grid and schematic for Scenario B is shown in Figure 3.9. The model parameters are the same for both scenarios and are shown in Table 3.3. The left and the right boundaries of the model are constant-pressure boundaries which establish a ground-water gradient of $0.00175 \mathrm{~m} / \mathrm{m}$. Ground water entering the boundaries is uncontaminated. The dispersion values were determined by changing the model dispersivities until the aqueous TCE concentrations of the model and the field data were similar.

Both scenarios involved the same simulation, that is, the dissolution of residual or pooled TCE and then the transport through advection and dispersion of the aqueous TCE, creating a plume. When the flow achieved steady state and the plume was no longer growing, the simulation was stopped. The concentration plumes of the two scenarios are shown in Figures 3.10 and 3.11 in units of volume of TCE per unit volume of water. The concentrations at the wells of both scenarios and the field sample concentrations are shown in Table 3.4. Since the well screens covered more than one cell block, the concentrations of all cell blocks used in the well were averaged. As can be seen from Table 3.4, the concentrations of Scenario A are much closer to the measured values than Scenario B's values are, indicating that it is a more likely occurrence. In fact the simulated MW-155 aqueous TCE concentration for Scenario B is two orders of magnitude larger than measured.

It was also determined by numerical simulation that these aqueous TCE concentrations could be simulated with a DNAPL source confined to the Upper Continental Deposits above the RGA. This finding underlines the uncertainty of the knowledge of the DNAPL zone, although Scenario A of Figure 3.6 is the most likely scenario because of the probable presence of through-going fractures in the Upper Continental Deposits. 


\subsection{DESIGN OF FIELD TEST}

The field test that INTERA undertook for DOE at PGDP is based on the concept (Jackson and Pickens, 1994) that DNAPLs can be identified in the subsurface by contacting the DNAPL with a micellar-surfactant solution. This occurs through the enhancement of the effective solubility of the DNAPL chemical by incorporating the DNAPL molecules within surfactant micelles, which are colloidal aggregates of surfactant molecules (see Figure 1.2). By the injection and extraction of micellarsurfactant solutions into a geologic formation, the DNAPL zone is contacted by the solution and the aqueous concentrations of the DNAPL chemicals are raised above their aqueous solubilities. This allows the positive identification of the DNAPL zone around the injection well and also allows the identification of other components in the DNAPL-in this case, PCE, which is suspected of being present in the DNAPL with TCE. This test also provides an excellent means of testing the efficacy of the surfactant for solubilizing the DNAPL, which was the primary purpose of the field test.

The particular configuration chosen for the field test at PGDP was a single-well injection-extraction test using $M W-156$, i.e., surfactants were first injected into the subsurface through $\mathrm{MW}-156$, pushed out 10 feet into the aquifer, and then extracted by back production through the same well. The rate of surfactant injection is a critical issue in that the rate should not cause mobilization of the TCE DNAPL while, at the same time, the surfactant front should migrate a significant distance into the aquifer over a reasonably short period of time. The concern with DNAPL mobilization is that it may result in more DNAPL seeping into the lower RGA than most probably is already present. While this would not seem to make matters much worse than they already are, it was not the intention of the test to promote deeper migration of the DNAPL, and the State of Kentucky demanded assurance that the McNairy formation would not be jeopardized further. Thus, the potential for DNAPL mobilization was addressed before the test.

Computations of DNAPL mobility require the computation of the interfacial, advective, and buoyancy forces affecting the fate of the DNAPL in the porous media. The two dimensionless numbers which measure these three forces are the bond $\left(N_{B}\right)$ and capillary $\left(N_{C}\right)$ numbers, which are (Pennell et al., 1984):

$$
N_{B}=\frac{\Delta \rho g k k_{r w}}{\sigma}
$$




$$
\mathrm{N}_{\mathrm{C}}=\frac{k \rho g i}{\sigma}=\frac{q \mu_{\mathrm{w}}}{\sigma}
$$

where:

$$
\begin{array}{lll}
\mathrm{k} & = & \text { intrinsic permeability of aquifer }\left(\mathrm{cm}^{2}\right) ; \\
k_{\mathrm{w}} & = & \text { relative permeability of aquifer to water (dimensionless); } \\
\rho & = & \text { density of the aqueous phase }\left(\mathrm{g} / \mathrm{cm}^{3}\right) ; \\
\sigma & = & \text { interfacial tension }\left(\text { dynes } / \mathrm{cm} \text { or } \mathrm{g} \mathrm{cm} / \mathrm{s}^{2} \mathrm{~cm}\right) ; \\
\mathrm{g} & = & \text { acceleration due to gravity }\left(\mathrm{cm} / \mathrm{s}^{2}\right) ; \\
\Delta \rho & = & \text { density difference between } \mathrm{DNAPL} \text { and water }\left(\mathrm{g} / \mathrm{cm}^{3}\right) ; \\
\mathrm{i} & = & \text { hydraulic gradient (dimensionless); } \\
\mathrm{q} & = & \text { Darcy velocity }(\mathrm{cm} / \mathrm{s}) ; \text { and } \\
\mu_{w} & = & \text { absolute viscosity of water in centipoise }(\mathrm{g} / \mathrm{s} \mathrm{cm})
\end{array}
$$

Assuming an injection rate of $1 \mathrm{gpm}$, which will produce a Darcy velocity of 530 $\mathrm{cm} /$ day at $M W-156$, and an interfacial tension of TCE (vs. ground water) of 10 dynes $/ \mathrm{cm}$, one obtains $N_{C}=6.2 \times 10^{-6}$. Assuming a density difference between TCE and ground water of $0.46 \mathrm{~g} / \mathrm{cm}^{3}$, an intrinsic permeability of $3 \times 10^{-8} \mathrm{~cm}^{2}\left(\mathrm{~K}=3 \times 10^{-3}\right.$ $\mathrm{cm} / \mathrm{s}$ ), and a relative permeability of 0.1 , one obtains $N_{B}=0.2 \times 10^{-5}$. The introduction of a surfactant solution might change the interfacial tension (IFT) between micellarsurfactant solution and the DNAPL. However, a sorbitan monooleate surfactant solution (T-MAZ 80K) with an IFT of 11 dynes/cm (vs. TCE) was injected, consequently no pronounced changes in either dimensionless number were expected. Even if the IFT had decreased to only 3 dynes $/ \mathrm{cm}$, values of $N_{C}=2.0 \times 10^{-5}$ and $N_{B}=0.6 \times 10^{-5}$ would have been obtained.

Abriola et al. (1993) have shown that PCE, a chlorinated solvent with similar properties to TCE, is initially mobilized in the vertical direction when the sum of the capillary and bond numbers is approximately $2 \times 10^{-4}$ (see Figure 4.1). For coarse sand (i.e., 20-30 mesh), the critical number could be as low as $4 \times 10^{-5}$. Since the sum of the capillary and bond numbers for the $1 \mathrm{gpm}$ surfactant injection-extraction test was approximately $0.8 \times 10^{-5}$, there was a safety factor of about twenty inhibiting vertical mobilization. If it was assumed that the logs of MW-156 were incorrect and that the sand adjacent to the well screen was coarse-grained rather than fine- to medium-grained (as reported and as indicated by the hydraulic conductivity value), then the factor of safety was about ten. Furthermore, it should be appreciated that the most probable consequence of vertical mobilization is the partial desaturation of pores and the redistribution of DNAPL elsewhere in the same formation, not a catastrophic cascading of DNAPL to greater depths. 
Assuming the hydraulic conductivity of the RGA is of the order of $10^{-5} \mathrm{~m} / \mathrm{s}$, the aquifer thickness is $2.1 \mathrm{~m}$ (set equal to the length of the well screen), and an injection rate of $\sim 1 \mathrm{gpm}(3.8 \mathrm{~L} / \mathrm{min})$, it takes approximately 4 days for a dilute surfactant solution to migrate $3 \mathrm{~m}$ radially from $\mathrm{MW}-156$, assuming no significant surfactant sorption. Thus, the volume of injectate was estimated to be $96 \mathrm{hrs} \times 3.8 \mathrm{~L} / \mathrm{min} \times 60 \mathrm{~min} / \mathrm{hr}=21,800 \mathrm{~L}$. Employing a $1 \%$ surfactant solution, approximately 60 gallons of pure surfactant would be injected.

The arrival time of 96 hours was computed using the GTFM code by the equation:

$$
\mathrm{t}=\frac{\pi \mathrm{r}^{2} \mathrm{~b} \theta}{\mathrm{Q}}
$$

where $b=2.1 \mathrm{~m}, \theta=0.35, Q=3.8 \mathrm{~L} / \mathrm{min}$, and $r=3.1 \mathrm{~m}$. The injection pressure was computed using the GTFM code as $1.7 \mathrm{~m}$ using a specific storage of $10^{-5} \mathrm{~m}^{-1}$ and a constant pressure boundary set at $1,500 \mathrm{~m}$.

Two conditions were considered which could contribute to a situation by which the surfactant front would not migrate as far as $3.1 \mathrm{~m}$ radially. In the first case, surfactant sorption and/or precipitation could retard surfactant migration. However, the high dissolved TCE concentrations recorded at MW-156 indicate that DNAPL is quite close to the well. Consequently, should the surfactant have a retardation factor $=1.2$, a migration distance of over $2.4 \mathrm{~m}$ would be attained, which was deemed sufficient for the purposes of this test. In the second case, because the screen length was approximately half the length of the sand pack, it was possible that injected surfactant might not enter the aquifer adjacent to the well screen. However, because of the low injection rate used, this was not deemed particularly likely.

To recover as much injected surfactant as possible for regulatory purposes, it was planned to extract a volume of ground water four times the injected volume, i.e., about $90,840 \mathrm{~L}$. 


\subsection{THE FIELD TEST}

\subsection{The Injection/Extraction System}

The test (see Section 4.0) consisted of a surfactant injection phase followed by an extraction phase in a single well, MW-156. As such, an equipment configuration versatile enough to accommodate both circumstances was required. The function of the injection system was to transfer a surfactant mix stored in tanks at the surface to the well. The function of the extraction system was to back produce the surfactant solution injected and any DNAPL which had been solubilized. Work began on setting up the injection/extraction system on July 27, and continued through August 1, 1994.

Figure 5.1 is a schematic showing the injection configuration. Reference to the figure shows that the surfactant mix was pumped from the tanks by a centrifugal pump located on the surface. Reinforced Teflon hose connected the pump to a drain at the base of each tank. Multiple valves installed in line provided for control of flow and divided the system into segments that could be sealed and individually drained upon disassembly, minimizing the risk of spillage. The surfactant mix was transferred into the well by means of a brass drop pipe installed to a depth of $18 \mathrm{~m}$ below grade, near the top of the screened interval.

Figure 5.2 is a schematic of the extraction system. Reference to the figure shows that the centrifugal pump at the surface of the injection system was replaced by an electric submersible pump downhole and that the metering system (i.e. rotameter and totalizing meter) has been reversed due to the change in direction of flow. The system discharge lines were connected to the top of the discharge tanks. Drop pipes were utilized in the tanks to minimize foaming of the surfactant solution as it was pumped in.

The area immediately around the well head and tank storage area was divided into the exclusion and contaminant reduction zones shown on Figure 5.3. The exclusion zone defined the area where contamination could occur. The contaminant reduction zone provided a transition zone between the exclusion zone and clean area of the site. Personnel entering the exclusion zone were required to have the health and safety training required by 29 CFR 1910.120 , the 40-hour health-and-safety course offered by PGDP, and the level of personnel protection specified by the project Health and Safety Plan.

The exclusion zone was provided with a $20 \mathrm{mil}$ cross laminate high density polyethylene secondary containment liner to guard against possible contamination of the site due to spillage. The liner was laid over a set of forms which created a series 
of secondary containment cells. In addition, a two-inch trash pump was kept on site so that, in the event of a spill, the spillage could be immediately pumped into an empty tank.

The injection/extraction tanks and surfactant drum were stored in the area identified as the Unloading Bay on Figure 5.3. This bay is designed to contain spills. It is constructed of concrete being sloped from both ends to a central drain. Placing the secondary containment liner down in the bay and adding forms to support the liner at each end provided much more spillage containment volume than required. Plywood sheeting was laid over the liner to protect it from the forklift traffic bringing tanks in and out of the bay.

A consideration in the overall design of the plumbing system was that it should maintain integrity, without leaking or rupturing, if a valve was inadvertently closed during operation or a line became clogged. All materials, including the reinforced Teflon hose, were chosen with this criterion in mind. In addition, a submersible pump was chosen which allowed the pumping rate to be controlled by adjusting the speed of revolution of the pump motor rather than running a pump at a constant speed and constricting flow by means of a valve. This assured that even if there was a break in the discharge line, no more than approximately $3.8 \mathrm{~L} / \mathrm{min}$ would be released until the personnel on site could shut the system down.

The rate of injection and extraction was closely monitored and controlled. Both the injection and extraction systems were equipped with a one-gallon-per-minute flow control or dole valve, a rotameter, and a totalizing flow meter. These items were mounted on a vertical panel to facilitate proper function and monitoring. Flow rates were checked and adjusted, if required, at intervals not exceeding an hour during all phases of the test (i.e., pre-test, injection, and extraction).

Power and lighting were supplied by PGDP, as were the 1,200-gallon (4,500-liter) polyethylene tanks used to store the surfactant solution and extraction water. All water extracted was picked up and transferred to tanker trucks by PGDP. Waste Management. The water was then transported to an incinerator at DOE Oak Ridge, Tennessee.

As it was critical that test operations were not interrupted, spare pumps, hose, fittings, and a generator were in place if needed. The only piece of equipment that failed during the test was a centrifugal pump used to inject the surfactant solution. This pump was immediately replaced and operations resumed. 


\subsection{The Pre-Test}

A pre-test of the system was conducted on August 3 and 4, with water being extracted from well $M W-156$. The purpose of the pre-test was to establish background concentrations of dissolved TCE, test the system's operation, and allow the field team to function together under actual test conditions.

A test of system integrity was conducted before initiating injection/extraction operations. The valves at the well head and discharge tank were closed and the system was pressurized with nitrogen gas. The initial test revealed several loose connections which were tightened and the system was repressurized. The system was then monitored for half an hour with no loss of pressure.

A total of $3,796 \mathrm{~L}(1,003$ gallons) of water was extracted between 1030 hours on August 3 and 0243 hours on August 4. The water was directed to a storage tank for handling as described in Section 5.1.

\subsection{Injection Operations}

A total of $19,553 \mathrm{~L}(5,166$ gallons) of surfactant solution was pumped into well $\mathrm{MW}$ 156 , beginning at 1830 hours on August 5 and ending at 0949 hours on August 9. The surfactant, T-MAZ 80K (PPG Industries, Inc.), was prepared as a $1 \%$ solution with drinking quality water obtained at PGDP. A Materials Safety Data Sheet for the surfactant is given in Appendix A. The rate of injection was $3.8 \mathrm{~L} / \mathrm{min}$.

The surfactant mixture was prepared in the injection tanks on site. Figure 5.4 is a schematic showing the mixing apparatus. Once the injection tank was filled with drinking-quality water, surfactant was transferred from the storage drum to a metered feed tank. With the recirculating pump in operation, the surfactant was bled into the system for mixing. The recirculating pump was kept in continuous operation during injection until the fluid level in the tank had been drawn down to the point that the mixing action caused the surfactant solution to foam.

During mixing operations, the flow rate of surfactant into the process was closely monitored. Samples of the mixture were collected at a minimum of hourly intervals by raising the diffuser in the tank and filling the sample vial from a diffuser port. These samples were visually monitored for the presence of surfactant globules. The surfactant mixture in each tank was measured prior to allowing the mixture to be injected into the subsurface. In addition, a sample of the surfactant mixture from each 
tank was captured at the system sampling connection during injection and analyzed. At no time was anything injected other than thoroughly mixed $1 \%$ surfactant solution.

During the course of injection, the rate remained generally steady at one gallon per minute plus or minus a few hundredths of a gallon. Only one significant deviation from this rate occurred during the first day of injection. For a period of less than one hour the average injection rate fell to $2.4 \mathrm{~L} / \mathrm{min}$. The average overall flow rate for the 87.32 hours of injection was $3.73 \mathrm{~L} / \mathrm{min}$.

Although the rate of injection remained constant, the water level in the well increased steadily over the entire period of injection. This was during the same period that the water level in piezometer 109, completed in the same stratigraphic horizon and monitored as a control point, fell. Piezometer 109 is located approximately $450 \mathrm{~m}$ due south of well MW-156. Figure 5.5 shows the injection rate and water levels in well MW-156. The water level in piezometer 109 during this time period is shown in Figure 5.6. The continuous rise in the water level at MW-156 suggests that the hydraulic conductivity of the aquifer/filter pack was progressively degraded. Possible explanations for this degradation are adhesion of the surfactant to the aquifer materials and some of the surfactant coming out of solution in the aquifer. Injection data, including injection rates and water levels, are given in Appendix B.

\subsection{Extraction Operations}

Injection of the surfactant solution ended at 0949 hours on August 9, 1994. At that time, the system was reconfigured for extraction operations. Fluid extraction was initiated at 1400 hours the same day and continued until 1100 hours on August 25, 1994. During that time, a total of 86,949 liters of fluid was removed from the well. This water was directed to polyethylene tanks for temporary storage at the bay area prior to removal. PGDP Waste Management staff periodically retrieved the tanks for transfer and disposal of the water, as described in Section 5.1.

The rate of extraction was verified and adjusted, if required, at a minimum of once an hour during the extraction phase. Although the rate periodically deviated from $3.8 \mathrm{~L}$ per minute, these variations were of short duration. The average extraction rate for the entire test was $3.80 \mathrm{~L} / \mathrm{min}(1.005 \mathrm{gpm})$.

Water-level changes in the well during the first few days of extraction lend support to the possibility that the hydraulic conductivity of the aquifer/filter pack was degraded by injection operations. Figure 5.7 shows the extraction rate and water level in well MW-156. The water level in control piezometer 109 during this period is shown in 
Figure 5.8. Water levels typically respond to the initiation of extraction operations by falling. The level in MW-156 actually rose for the first two days and did not begin to decline steadily until the fifth day. Such behavior would be expected if material in the aquifer/filter pack responsible for a general degradation of hydraulic conductivity were being removed by back production. Water levels at the control point, Piezometer 109, were generally declining during this same period. Extraction phase data, to include extraction rates and water levels, are given in Appendix $C$.

Upon completion of the test, the extraction system was disassembled and all equipment removed to on-site storage facilities. Equipment which had come into contact with the extracted ground water was first scanned for radiation by personnel from the PGDP Health Physics Department and decontaminated at an on-site decontamination pad before storage.

\subsection{Sampling Procedures}

Water samples were collected at MW-156 and MW-155 throughout the test. Samples from MW-156 were analyzed for trichloroethene (TCE), surfactant, technetium-99 (TC-99), temperature, and dichloroethene (DCE). MW-155 samples were analyzed for TCE, surfactant, dissolved oxygen (DO), temperature, and $\mathrm{pH}$. By design, more samples were collected than were analyzed. Water samples were collected from MW-156 and MW-155 as outlined in the Sampling and Analysis Plan. PGDP staff collected the samples from MW-155, and INTERA and PGDP staff collected the samples from MW-156.

The MW-155 samples were collected according to the projected sampling schedule in the Sampling and Analysis Plan, except that two samples per day were collected during the surfactant injection phase also. The number of samples collected from MW-156 also exceeded the number projected in the Sampling and Analysis Plan. This was because of the unanticipated slow recovery of TCE concentrations in MW-156 during the extraction phase. The slow return to background TCE concentrations required an extension of the period during which frequent sampling was needed. Thus, hourly samples were collected during the first 4.5 days of the extraction phase. This period was followed by a 2-day period of bi-hourly sampling before the sampling frequency was lowered to 6 times per day.

INTERA analyzed for TCE and surfactant concentrations in MW-155 and MW-156 samples at the PGDP laboratory trailer (T-17). These samples were collected in $20 \mathrm{~mL}$ glass EPA vials with teflon septa. Triplicate samples from $M W-156$ were collected at least once for every 10 samples collected. All the samples from MW-155 were 
triplicates, but only two triplicates per set were given to INTERA for analysis. The remaining triplicates from $\mathrm{MW}-155$ were analyzed by PGDP.

In addition to these samples, 2 to 6 Tc-99 samples were collected daily from MW-156. These samples were collected in $500 \mathrm{~mL}$ polyethylene bottles containing nitric acid preservative.

Finally, additional samples for "IR Qual," alpha and beta radiation, and volatile organic compounds (VOCs) were collected in containers provided by PGDP. The VOC samples were analyzed by PGDP for TCE, 1,1,1-trichloroethane, and pyrene.

Sampling from MW-156 began by opening the valve on the sample line to allow about one liter of water to flush through the line into a waste bucket. The flow was then maintained at a rate of approximately $100 \mathrm{~mL} / \mathrm{min}$ while sample bottles were filled. The temperature of the sample port purge water was frequently measured and recorded in the sample log book. For VOC samples, the amount of headspace in the bottles was always kept below $0.1 \mathrm{~mL}$ and almost always below about $0.01 \mathrm{~mL}$.

The small amount of headspace allowed in the sample vials has a negligible impact on the concentrations of TCE measured. A headspace of $0.1 \mathrm{~mL}$ can only contain about $0.003 \mathrm{mg}$ TCE as estimated by the following calculations. First, if it is assumed that the water contains TCE at a concentration (C) of $100 \mathrm{mg} / \mathrm{L}$, then according to the Henry's Law constant for TCE $\left(\mathrm{H}_{\text {TCE }}=0.007 \mathrm{~atm}-\mathrm{m}^{3} / \mathrm{mol}\right.$, Schwille, 1988), the partial pressure of TCE in the headspace $\left(P_{\text {TCE }}\right)$ would be

$$
P_{\mathrm{TCE}}=\frac{\mathrm{H}_{\mathrm{TCE}} * \mathrm{C}}{\mathrm{MW}_{\mathrm{TCE}}}=0.0053 \mathrm{~atm}
$$

$\mathrm{MW}_{\text {TCE }}$ is the molecular weight of TCE $(131.5 \mathrm{~g} / \mathrm{mol})$. The mass of TCE in the headspace $\left(M_{\text {hrs }}\right)$ can be estimated from the following equation

$$
M_{\mathrm{hs}}=\frac{P_{\mathrm{TCE}}}{P_{\mathrm{T}}} * G * V_{\mathrm{hs}} * M \mathrm{~W}_{\mathrm{TCE}}=0.003 \mathrm{mg}
$$

where $P_{\mathrm{T}}$ is the total pressure $(1 \mathrm{~atm}), \mathrm{G}$ is the standard molar volume for an ideal gas $(0.0446 \mathrm{~mol} / \mathrm{L})$, and $V_{\mathrm{hs}}$ is the volume of headspace $(0.1 \mathrm{~mL})$. The mass of TCE in the water $\left(M_{\mathrm{aq}}\right)$ is calculated to be 


$$
M_{\mathrm{aq}}=\mathrm{C} * \mathrm{~V}_{\mathrm{aq}}=2 \mathrm{mg}
$$

where $V_{\mathrm{aq}}$ is the volume of water $(20 \mathrm{~mL})$. Comparing $M_{\mathrm{th}}$ to $M_{\mathrm{aq}}$ reveals that $99.85 \%$ of the TCE is in the water. Thus, volatilization of TCE into a very large $0.1 \mathrm{~mL}$ headspace could only decrease the aqueous concentration by $0.15 \%$. Of course, the error would be even smaller in water containing surfactant above the critical micelle concentration. Certainly, the potential error in TCE analyses introduced by a large 0.1 $\mathrm{mL}$ headspace in a $20 \mathrm{~mL}$ vial is negligible compared to the error introduced by the injection of sample to the gas chromatograph (GC), the calibration of the GC, and the detector response. The accuracy and precision of $G C$ analyses is discussed in depth later.

All samples from MW-156 were immediately placed in coolers containing frozen "blueice" packs. Within 24 hours they were transferred either to a refrigerator in the field laboratory trailer or to PGDP. Those transferred to PGDP were accompanied by chainof-custody forms. Samples from MW-155 were transferred to INTERA upon collection and were immediately placed in the field coolers to await delivery to the refrigerator in the field laboratory trailer.

\subsection{Field Analytical Procedures}

The field analytical procedures were outlined in detail in the Sampling and Analysis Plan. Basically, these procedures refer to the analyses performed by INTERA at the field laboratory trailer, i.e., surfactant, TCE, and some DCE analyses.

\subsubsection{TCE and DCE Analysis}

All the field TCE analyses for samples from MW-156 were performed on an SRI 8610 gas chromatograph (GC) equipped with an electrolytic conductivity detector (ELCD). At first, this GC was used to analyze samples from MW-155, but because the TCE detection limit for the ELCD is about $1 \mathrm{mg} / \mathrm{L}$, the backup GC, an SRI 8610a with an electron capture detector (ECD), was used for the remaining samples from MW-155. The 8610 a with ECD was also used to measure DCE concentrations in a few samples from MW-156.

Injections were performed using a 1 microliter Hamilton 7000 series syringe with Chaney adapter. The syringe was cleaned in methanol (5 pumps) and then in deionized rinse water ( 5 pumps) before collecting a microliter of sample. To check the effectiveness of this cleaning procedure, a microliter of the deionized rinse water was frequently injected into the GC. No more than a negligible TCE peak ever resulted. 
The sample was collected by inserting the needle through the teflon septum of the 20 $\mathrm{mL}$ sample vial, pumping five times to remove any air bubbles or residual from the deionized rinse water, and slowly filling the syringe. Within about 5 seconds, the sample was rapidly injected onto the column of the GC.

Before each batch of analyses, the GCs were allowed to warm up and calibration standards were run. Retention times, peak heights, and peak areas were recorded in the laboratory log book. Each calibration standard was run at least twice to ensure reproducible measurements. When the peak area of a repeated injection of a calibration standard differed from the previous measurement by more than $10 \%$, an additional injection was performed for an additional peak area measurement. Drift in GC response was monitored by rerunning standards after about every 10 samples analyzed. When the drift appeared greater than $10 \%$, all of the calibration standards were rerun.

Occasionally, the response of the 8610 with ELCD drifted and/or varied markedly. When this happened, the capillary tubing of the detector was inspected. If the tubing was believed damaged, it was replaced. During the course of the field test, the capillary tubing was replaced three times. The 8610 a with ECD proved more reliable than the 8610 with ELCD. Measurements were always reproducible and drifting was never a problem after the initial warm-up period.

\subsubsection{Surfactant Analysis}

The concentration of surfactant, T-MAZ-80K, was measured using a Hitachi U-2000 UV spectrophotometer and rectangular quartz cuvettes. The spectrophotometer measures the difference in absorbance at a given wavelength between a cuvette containing an aliquot of sample and one containing a blank.

A standard of $0.1 \%$ surfactant in deionized water was used to determine the optimum wavelength for concentration measurements. The scan from 200 to $800 \mathrm{~nm}$ indicated that $232.4 \mathrm{~nm}$ was the optimum wavelength. However, TCE strongly absorbs UV light below $240 \mathrm{~nm}$. As the wavelength increases to $250 \mathrm{~nm}$, the TCE absorbance fades rapidly. Thus, the wavelength for T-MAZ-8OK concentration measurements was chosen to be $245 \mathrm{~nm}$. At this wavelength, the absorbance of about $40 \mathrm{mg} / \mathrm{L}$ TCE was approximately 0.02 while the absorbance of $0.1 \%$ T-MAZ was about 0.64 .

Surfactant analysis of a sample was always performed after the TCE concentration was determined so that possible interference in surfactant concentration measurement could be determined. As it turned out, samples containing high concentrations of surfactant 
(greater than $0.1 \%$ ) had low concentrations of TCE (less than $50 \mathrm{mg} / \mathrm{L}$ ). Also, because all samples with high concentrations of surfactant had to be diluted 9 to 1 with deionized water prior to surfactant analysis, the diluted samples contained less than 5 $\mathrm{mg} / \mathrm{L}$ TCE. Thus, for these samples, no special procedures were necessary to remove TCE prior to surfactant analysis.

When surfactant concentrations were low and TCE concentrations were high, TCE had to be sparged from the sample prior to surfactant analysis. This was done by bubbling nitrogen into the sample for about 10 minutes. The TCE concentration was measured after the sparging to make sure that it was below $40 \mathrm{mg} / \mathrm{L}$.

The UV spectrophotometer provided highly reliable and reproducible measurements as demonstrated by repeated readings of calibration standards. The practical quantitation limit for the surfactant at $245 \mathrm{~nm}$ was around $0.01 \%$.

Surfactant concentrations in MW-156 samples were also measured in the PGDP laboratory. The results, listed in Table 5.3 and plotted in Figure 5.11, closely match the results obtained by INTERA.

\subsubsection{Temperature Measurement}

Thermometers were used to measure the temperature of water flowing out of the sample port from MW-156, coolers, and refrigerators. Special thermometers with data loggers were used to monitor the temperature of the refrigerators at the field laboratory trailer.

Three field thermometers, each having a slightly different range of temperatures, were used at the site. Prior to use they were tested against each other in ice water at about $2.5^{\circ} \mathrm{C}$ and tap water at about $20^{\circ} \mathrm{C}$. The readings from each thermometer were within $0.5^{\circ} \mathrm{C}$ at both temperatures. Temperature measurement simply involved immersing the tip of the thermometer in the fluid being analyzed for at least 30 seconds.

\subsection{MW-156 Results}

MW-156, which is screened in the Upper RGA, was monitored for temperature and concentrations of TCE, surfactant, TC-99, and DCE. The following sections present the results from each type of analysis. 


\subsubsection{TCE Concentrations}

A summary of the qualified TCE concentrations measured by INTERA appears in Table 5.1. After rigorous calibration calculations and QNVQC screening, some of the data collected by INTERA were eliminated due to excessive drift in GC response, manifested by rapidly increasing or decreasing peak areas for given standards over short periods of time. When more than one qualified concentration measurement was available for a given sample, the measurements were averaged. This table contains the qualified and averaged data resulting from the QAVQC screening. The calibration curves, squares of the correlation coefficients ( $R$ Squared), and qualified raw data are included in Appendix D.

The precision of the measurements was determined by calculating $95 \%$ confidence intervals for the field triplicates. Confidence intervals were estimated assuming a Student's t distribution with two degrees of freedom. The estimates are presented in Table 5.2 and plotted in Figure 5.9. Measurements from 15 of the 17 triplicates indicate confidence intervals within $\pm 16 \%$ of the sample mean. Only the 2 sets of triplicates from the pre-test showed $95 \%$ confidence intervals larger than $\pm 16 \%$.

The accuracy of the measurements depends on the calibration standards and the calibration curves. A review of the $R$ Squared values (the squares of the correlation coefficients) in Appendix D reveals that $38 \%$ of the $R$ Square values were 0.999 or higher, $38 \%$ were in the range of 0.995 to 0.999 , and $23 \%$ were in the range of 0.99 to 0.995 . Note that if $R$ Square equals 0.990 , then the correlation coefficient (the square root of $R$ Square) is 0.995 .

A final check on the accuracy of field TCE concentration measurements is provided by the results of the PGDP TCE measurements listed in Table 5.3. The differences in matched pairs were calculated to determine the mean, sample standard deviation, and whether the differences in field and PGDP lab measurements were significantly different at the 5\% significance level. The results are shown in Table 5.4.

The hypothesis test indicated that TCE measurements by the PGDP lab were significantly lower than the field measurements. Table 5.4 indicates that the PGDP measurements were consistently higher than field measurements during the pre-test and consistently lower than the field measurements during last 12 days of the extraction period. While differences are apparent, they are not large considering the differences in analytical equipment and the precision of the measurements; the pairs with the largest differences still agree within a factor of 2. The procedures, equipment, and notes taken during the field and laboratory analyses would need to be closely 
examined to determine which measurements are most credible. However, it should be. noted that the field-measured TCE data (Figure 5.10) indicates that the final TCE concentrations during the extraction phase are about equal to the pre-test values, which is not the case for the laboratory data (Figure 5.11). Because each set of measurements provides clear and unconflicting results regarding the objectives of the test (i.e., the efficacy of the surfactant), there is no need to determine which measurements are more accurate.

A plot of the field TCE concentration measurements from Table 5.1 is shown in Figure 5.10. The PGDP TCE concentration measurements are plotted in Figure 5.11. The measurements are plotted versus time in days since the extraction phase began. Negative time indicates time before the beginning of the extraction phase. The pre-test, surfactant injection phase, and extraction phase are marked on the figure. The TCE concentration measured during the surfactant injection phase is the TCE concentration of the surfactant solution being injected.

According to the field data, the approximate TCE concentration during the pre-test was around $350 \mathrm{mg} / \mathrm{L}$. The concentration dropped to less than $1 \mathrm{mg} / \mathrm{L}$ during the injection phase while clean surfactant solution was injected. Once the extraction phase started, the TCE concentration slowly increased to around $75 \mathrm{mg} / \mathrm{L}$ after 4 days, increased more rapidly in the next 4 days to about $250 \mathrm{mg} / \mathrm{L}$, and then more slowly to about $320 \mathrm{mg} / \mathrm{L}$ by the end of the extraction phase. The apparent dip in TCE concentrations during the ninth day may or may not be real. While the field data shows a dip at this time, the PGDP laboratory data suggests a temporary leveling off instead.

\subsubsection{Surfactant Concentrations}

All surfactant data obtained during the test exceeded QAVC standards and are included in Table 5.1. Unlike the GC, the UV-spectrophotometer was calibrated to calculate concentrations directly, without resorting to calculation of peak areas. The calibration curve was forced through the origin (i.e., $A B S=0$ at $0.000 \%$ surfactant concentration). Calibration was highly consistent throughout the test and the squares of the correlation coefficients always exceeded 0.999. Precision calculations based on triplicates indicate a $95 \%$ confidence interval of about $\pm 4 \%$ of the mean concentration for high surfactant concentrations. The practical detection limit was about $0.01 \%$ due to background interferences and the sensitivity of the detector at $245 \mathrm{~nm}$. The accuracy and precision calculations for the surfactant analyses are included in Appendix E. 
The data are plotted in Figure 5.10. The data in this figure are in units of \% by volume $\left(P_{v N}\right)$ and are calculated from the following equation

$$
P_{v / V}=100 \% * \frac{M_{\text {surf }}}{M_{T}} * \frac{d_{T}}{d_{\text {surf }}}
$$

where $M_{\text {surf }} / M_{T}$ is the weight fraction of surfactant in the solution and $d_{T} / d_{\text {surf }}$ is the ratio of the density of the solution (approximately $1.0 \mathrm{~g} / \mathrm{mL}$ ) to the density of surfactant $(1.09 \mathrm{~g} / \mathrm{mL})$.

The data show that the surfactant was injected at a concentration of around $1 \%$ by volume. However, almost as soon as the extraction phase began, the surfactant concentration in MW-156 started falling. In about 2 days, the surfactant concentration fell to about $0.15 \%$ by volume, and after about 5 days of extraction it was below practical detection limits of $0.01 \%$. Comparing areas under the curve for the surfactant injection and extraction phases indicates that about $34 \%$ of the surfactant injected was recovered.

\subsubsection{Tc-99 Concentrations}

The results of the Tc-99 analyses by PGDP are included in Table 5.3 and plotted in Figure 5.11. The Tc-99 concentration at MW-156 during the pre-test was around $107 \mathrm{pCi} / \mathrm{L}$. Although there was some scatter in the Tc-99 data during the extraction phase, it appears that the Tc-99 concentration dropped to a minimum around 20-40 pCi/L in the first two days of extraction and then slowly recovered to near pretest concentrations after about 7 days of extraction where it leveled off.

\subsubsection{Temperature}

Temperature measurements of extracted ground water at $M W-156$ can be found in Table 5.1. The temperature leveled off around $21^{\circ} \mathrm{C}$ during the latter part of the pretest. Although the temperature of the surfactant solution was never measured by thermometer, solar heating in the mixing tanks caused it to become quite warm compared to fresh ground water. This is further indicated by the high temperatures measured shortly after the extraction phase began. The temperature of the extracted ground water returned to pre-test values within about 4 to 5 days. A graph of the temperature data is shown in Figure 5.12. 


\subsubsection{DCE Concentrations}

The sharp drop in surfactant concentration in MW-156 during the first two days of extraction was curious. An early suggestion was that the surfactant was being degraded by in situ microorganisms. The only indicator variable INTERA was equipped to analyze for was the concentration dichloroethene (DCE), a product of the degradation of TCE. If the microbial activity was stimulated by the surfactant, it could cause increased biodegradation of TCE to DCE.

Samples from the pre-test and the extraction period were analyzed by the $8610 \mathrm{a}$ GC with ECD. Calibration was limited to two standards and a blank because time was limited and the actual concentrations in the samples were not as important as the relative concentrations. Measuring relative concentrations does not require calibration because they are directly reflected in the raw response of the GC.

Figure 5.13 is a plot of the DCE measurements showing the DCE concentration around $1 \mathrm{mg} / \mathrm{L}$ throughout the test. Although only a few measurements were made, it appears that the DCE concentration was slightly higher during the initial part of the extraction phase, suggesting some increased microbial activity. However, considering the high concentrations of TCE, much higher concentrations of DCE would be expected if the microbial activity increased to the level required to degrade a considerable proportion of the injected surfactant. This finding supports the conclusion that microbial activity was not likely the cause of the loss of the bulk of the surfactant injected. The DCE measurements and calibration data can be found in Appendix D.

\subsection{MW-155 Results}

MW-155, which is screened in the lower RGA, was monitored for temperature, $\mathrm{pH}$, and concentrations of TCE, surfactant, and dissolved oxygen. The purpose of monitoring this well was to determine if the injection of a micellar-surfactant solution into a suspected DNAPL zone around MW-156 would cause vertical mobilization of the DNAPL, which would appear, together with surfactants, in MW-155. The following sections present the results from each type of analysis.

\subsubsection{TCE Concentrations}

The measured TCE concentrations at MW-155 are shown in Figure 5.14. They remained around $1.5 \mathrm{mg} / \mathrm{L}$ for the entire test. A slight increase in measured TCE concentration was observed over the course of the experiment. However, the increase is so small that it easily could have occurred naturally regardless of the surfactant test. 
It is also possible that the extended extraction period drew new ground water of slightly different composition into $\mathrm{MW}-155$ from farther outside the testing zone. The data is summarized in Table 5.5.

The MW-155 samples were first analyzed for TCE using the 8610 GC with ELCD, but because the TCE concentrations were near the detection limits of this GC, a switch was made to the $8610 \mathrm{a}$ GC with ECD. The calibration curves and raw data are presented in Appendix $F$. In all cases the square of the correlation coefficient (R Squared) is greater than 0.995 (which implies that the correlation coefficient is always greater than 0.9975).

The best estimate of the precision of the MW-155 TCE measurements is derived by: (1) taking a linear regression of the data collected during the surfactant injection and extraction periods versus time; (2) calculating the standard deviation from this line; and (3) determining the Student's t statistic for the $95 \%$ confidence interval. Although this procedure assumes that the TCE concentration is linearly related to time (as it appears to be), it allows a much larger sample population $(n=39)$ from which to estimate $95 \%$ confidence intervals. The sample standard deviation from the fitted line was calculated to be $0.13 \mathrm{mg} / \mathrm{L}$, giving a Student $t$ test statistic, $t_{0.025}$, of about 2.025 . This value is used to estimate the $95 \%$ confidence interval for each independent TCE concentration measured. The result for this data set is a $95 \%$ confidence interval for each measurement of approximately $\pm 0.26 \mathrm{mg} / \mathrm{L}$ (or approximately $\pm 18 \%$ ).

A few of the MW-155 samples were analyzed by PGDP for TCE concentrations. These results are listed in Table 5.6. These measurements closely match the field measurements by INTERA.

The differences in field and PGDP lab measurements were analyzed by calculating the mean and standard deviation of the differences of matched pairs. These statistics are shown in Table 5.7. A hypothesis test was used to indicate whether the differences in the field and PGDP laboratory measurements are significantly different. Assuming the matched-pair differences can be described by the Student's t distribution, it was found that the field and PGDP TCE measurements for MW-155 are not significantly different.

\subsubsection{Surfactant Concentrations}

Samples analyzed from MW-155 showed no signs of surfactant. Had surfactant reached $M W-155$, its maximum concentration at $M W-155$ would have appeared at the end of the surfactant injection period and the beginning of the extraction period. In addition, TCE concentrations would have increased because the contaminated ground water displaced by the injected surfactant solution would have reached $\mathrm{MW}-155$ before 
the surfactant. The TCE concentration at MW-155 remained around $1.5 \mathrm{mg} / \mathrm{L}$, which is far below the $350 \mathrm{mg} / \mathrm{L}$ TCE concentration in the contaminated ground water in the vicinity of MW-156 prior to the injection of the surfactant solution.

\subsubsection{Dissolved Oxygen Concentrations, Temperature, and $\mathrm{pH}$}

The dissolved oxygen, temperature, and $\mathrm{pH}$ of the $\mathrm{MW}-155$ samples were analyzed by PGDP in the field using a Hydrolab probe with an in-line flow cell. Table 5.6 contains the results. The dissolved oxygen (DO) measurements fluctuated between about 3 and $7 \mathrm{mg} / \mathrm{L}$ with no clear trend during the test. The data is plotted in Figure 5.15.

There appeared to be no real trend in temperature either. The temperature of $\mathrm{MW}-155$ samples was nearly always between 18 and $22^{\circ} \mathrm{C}$. A plot of the temperature versus time is displayed in Figure 5.16.

The $\mathrm{pH}$ was fairly steady during the test except for an increasing trend during days 9 through 12 of the extraction period. Prior to this rise, the $\mathrm{pH}$ was around 6 , and afterwards it appeared to level off at $\mathrm{pH}$ 6.5. The $\mathrm{pH}$ data is shown in Figure 5.17. If this $\mathrm{pH}$ change is real (i.e., not due to analytical error), it could be due to naturally occurring processes. Whether such changes in $\mathrm{pH}$ at $\mathrm{MW}-155$ could result naturally could be determined by examining historical $\mathrm{pH}$ data for $\mathrm{MW}-155$. It is also possible that the extended extraction period drew new ground water of slightly different composition into $\mathrm{MW}-155$ from farther outside the testing zone.

The relatively low $\mathrm{pH}$ values and the presence of significant amounts of $\mathrm{DO}$ in the MW-155 data indicate that the ground waters sampled in MW-155 have not migrated to this part of the RGA by intergranular flow through the Upper Continental Deposits above the RGA (see Figure 3.2). These deposits likely contain substantial amounts of carbonate minerals, in particular calcite and dolomite, as well as considerable amounts of organic matter and other reductants. Intergranular flow through a thick sequence of such common sedimentary materials would result in $\mathrm{pH}$ values greater than neutral and the reduction of DO to non-measurable amounts (e.g., Jackson and Patterson, 1982). Rather, the data argue for a mechanism of rapid recharge of ground water to the RGA through an interconnected network of fractures in the Upper Continental Deposits such as has been postulated for DNAPL migration at the C- 400 site by Clausen et al. (1992). Fracture flow would expose ground-water recharge to lesser amounts of carbonate minerals and organic matter over shorter residence times, such that recharge to the RGA could produce a ground water similar to that observed in MW-155. 


\subsection{Simulation of Test}

The recovery responses of the TCE, TC-99, and surfactant from the field were investigated using numerical simulations. The simulations were performed using the SWIFT II flow-and-transport simulator. The model is a 2-dimensional cylindrical grid of the upper RGA centered on the injection/extraction well MW-156. The model consists of 20 radial grid blocks that extend from the wellbore out to 100 feet and 7 vertical layers which make up the 7-foot completed interval of the well. An infinite aquifer boundary condition at the outer edge of the model grid was applied using the Carter-Tracy method. The model parameters are consistent with the parameters used in Section 3.0 and listed in Table 3.3.

The normalized $(\mathrm{C} / \mathrm{Co})$ recovery responses of the TCE and TC-99 are plotted against the simulated recovery of a conservative tracer in Figure 5.18. The simulation of the conservative tracer response was performed by injecting clean water into formation water which contained the tracer. As in the field test, injection continued for 3.72 days, followed by a static period of 0.17 days, followed by extraction for 16 days. From the extraction-period plot it can be seen that the Tc-99 reacted as a conservative tracer with the exception of very early time. However, the TCE responded nonconservatively.

Figure 5.19 shows the normalized surfactant recovery plotted against the simulated recovery of a conservative tracer. In this simulation, a conservative tracer was injected into clean formation water for 3.72 days, followed by a static period of 0.17 days, followed by extraction for 16 days. The plot shows that the surfactant injected during the field test did not respond conservatively.

The conservative recovery of the Tc-99 and the non-conservative recoveries for the surfactant and TCE suggest that the surfactant may have affected the TCE recovery. The surfactant, had it become immobilized by sorbing onto the RGA soils or precipitating in the pore space, may have increased the available sites for sorption of TCE. This would have caused the responses for both the surfactant and TCE to be nonconservative. 


\subsection{SUMMARY AND CONCLUSIONS}

The specific objectives of this first phase of the project were:

1. to screen surfactants in the laboratory and identify those that will efficiently extract PCE, carbon tetrachloride, and TCE from sand aquifers by micellar solubilization, and then to investigate the physical-chemical properties of the best surfactants; and

2. to test, in situ, the efficacy of one of these surfactants to solubilize a TCE DNAPL (with minor amounts of PCE) by injection and then extraction of the surfactant solution through an existing well set within a sand and gravel aquifer at the Paducah Gaseous Diffusion Plant.

A total of 99 surfactants ( 25 nonionics and 74 anionics) were screened for their ability to solubilize TCE, PCE, and carbon tetrachloride. Ten of the 99 surfactants were capable of solubilizing TCE to concentrations greater than $15,000 \mathrm{mg} / \mathrm{L}$. Four surfactants were identified as good solubilizers of all three DNAPL chemicals: a sorbitan monooleate (T-MAZ-80), an alkylaryl sulfonate isopropylamine, a secondary alcohol ethoxylate (Tergitol 15-S-12), and a polyoxyethylene oleamide.

Tergitol was the first choice because of its excellent solubilizing ability and its low propensity to sorb. However, this secondary alcohol ethoxylate did not meet the Commonwealth of Kentucky's acceptance criteria because of the potential presence of unreacted reagents which are banned for injection into ground waters in Kentucky. Consequently, it was decided to use a surfactant approved for use by the FDA as a food-grade additive, namely, T-MAZ-80K, which is manufactured by PPG Chemicals. As a $1 \%$ micellar-surfactant solution, this sorbitan monooleate has a solubilization capacity of $16,000 \mathrm{mg}$ TCE/L, but has a higher propensity to sorb to clays than has the Tergitol.

After a year of intense field work by PGDP, the first site chosen for in situ testing was found to be unsuitable for conducting a short-term injection-extraction test. Therefore, a second site at PGDP was chosen, the C-400 site, on account of the fact that a particular well at the site (MW-156) had a sufficiently high hydraulic conductivity and had TCE concentrations $>100 \mathrm{mg} / \mathrm{L}$, which suggested a nearby TCE DNAPL zone in this aquifer.

A field test of the efficacy of sorbitan monooleate in solubilizing TCE DNAPL was conducted in August 1994. The injection phase lasted 96 hours, during which time a $1 \%$ surfactant solution was injected at the rate of $3.8 \mathrm{~L} / \mathrm{min}(1 \mathrm{gpm})$. The extraction 
phase lasted 16 days at a rate of $3.8 \mathrm{~L} / \mathrm{min}$. Only one third of the injected surfactant was recovered during the extraction period and, consequently, there was no enhancement in the concentrations of TCE recovered from the well. It is believed that the remainder of the surfactant became sorbed to the aquifer materials or underwent precipitation or liquid crystal formation or some combination of the above. TCE behaved nonconservatively during the early stages of extraction, suggesting that some may have been sorbed to the immobilized surfactant. Therefore, the test has demonstrated that sorbitan monooleate is unsuitable for use as a solubilizer in this aquifer.

It is probable that this result could have been identified in the laboratory beforehand and an alternative surfactant could have been chosen and tested. Paradoxically, these same results demonstrate that the single-well test is a useful method for the in situ testing of surfactants or cosolvents before proceeding to larger-scale field testing or remediation.

PGDP's original conceptual model of DNAPL migration and distribution at the C-400 site (Figure 3.5), which is based on the work of Kueper (1991) and supported by the numerical simulations of McConnell et al. (1994), has been tested by numerical simulation and found to be inconsistent with the aqueous TCE concentrations beneath the site. A more probable conceptual model of DNAPL within the sand and gravel aquifer is presented in this report. This model assumes that DNAPL migrated through a fracture network system in the Upper Continental Deposits and penetrated the sand and gravel aquifer (RGA) beneath. This new scenario of DNAPL distribution indicates that it is advisable to repeat this test, following laboratory studies of the reaction of surfactants with the aquifer materials, by an interwell surfactant test, rather than a single-well test, to raise the probability that the DNAPL zone will be encountered by the injected surfactant solution. 


\subsection{RECOMMENDATIONS}

While it has been shown that the micellar surfactant solution did not perform as intended, the single-well test demonstrated its utility for testing surfactants prior to fullscale SEAR. It is probable that the loss of surfactant could have been identified in laboratory tests, had it been possible to ship core from PGDP to SUNY Buffalo for testing beforehand. Furthermore, some way must be found to allow Sandia National Laboratories to play its designated role in this research. Had this contract been in place, some of the difficulties experienced in the field with the surfactant might have been avoided.

Therefore, we urge that the restrictions placed on the testing of the surfactants with aquifer materials from the RGA be swiftly resolved so that aquifer materials from the RGA can be shipped to SUNY-Buffalo and Sandia National Laboratories. Failing this, it will be necessary to set up a temporary laboratory at PGDP to conduct the necessary tests. The expense of such a solution strongly recommends the resolution of the restrictions.

The understanding of the distribution of DNAPL in the RGA beneath C-400 at PGDP is limited. This is quite typical of sites with DNAPL contamination, because of the complexity of the problem. The anticipated program of drilling and coring planned (WAG-6 program) for 1995 at C-400 should be devised to help test divergent hypotheses of the geometry of the DNAPL zone which have been explored in this report. The application of NAPL partitioning tracer tests and multiphase, multicomponent simulators permit an integrated approach to the characterization of DNAPL zones.

Recommendation 1: $\quad$ The program of drilling and aquifer coring planned by PGDP for WAG-6 1995 should be complemented with field and computational studies to develop a better understanding of the geometry of the DNAPL zones in the Regional Gravel Aquifer and the nature of DNAPL migration at PGDP.

Because of the limited understanding of the DNAPL zone and the loss of the surfactant in situ, it would be advisable to repeat this test as an interwell test rather than a singlewell test, so that a larger volume of the RGA can be tested for the presence and composition of the DNAPL. Figure 7.1 is a schematic showing how an interwell DNAPL solubilization test would be undertaken, assuming that the test zone would contain only a limited thickness of residual DNAPL in the upper RGA. A micellar- 
surfactant solution would be introduced through the injection well and produced at the extraction well. Because the zone of residual TCE DNAPL is much thinner than the thickness of the upper RGA, which is identified as having a hydraulic conductivity of $3 \times 10^{-3} \mathrm{~cm} / \mathrm{s}$, the solubilized TCE will be greatly diluted by uncontaminated ground water. This effect is shown in Figure 7.2, which displays the effluent surfactant and TCE concentrations. The coelution of TCE and surfactant in Figure 7.2 indicates the presence of DNAPL and will permit an in situ evaluation of the efficacy of a particular surfactant solution.

Recommendation 2: $\quad$ Following the re-evaluation of appropriate surfactants for use in the RGA at Paducah and the installation of an additional well at the C-400 site, an interwell DNAPL solubilization test should be undertaken over a distance of at least $10 \mathrm{~m}$ to test the efficacy of DNAPL solubilization by micellar surfactant solutions. 


\subsection{REFERENCES}

Abriola, L.M., G.A. Pope, and W.H. Wade, 1993. Investigation of Surfactant-Enhanced Remediation of Aquifers Contaminated by Dense Non-Aqueous Phase Liquids. Quarterly progress report for the period September 1993 to December 1993 to R.S. Kerr Environmental Research Laboratory, Ada, OK, by the Universities of Michigan and Texas.

$\mathrm{CH} 2 \mathrm{M}$ Hill, 1992. PGDP Phase II Site Investigation. Technical Memorandum No. 6: Aquifer Recovery Slug Testing, prepared by M.K. Dwyer and A. Eddebbarh. $\mathrm{CH} 2 \mathrm{M}$ Hill Southeast Inc., Oak Ridge, TN.

Clausen, J.L., J.W. Douthitt, K.R. Davis, and B.E. Phillips, 1992. Report of the Paducah Gaseous Diffusion Plant, Groundwater Investigation, Phase III, KY/E-150. Martin Marietta Energy Systems, Inc., Paducah, KY.

EPA, 1992. Estimating Potential for Occurrence of DNAPL at Superfund Sites. EPA Publication 9355.4-07FS, RSKERL, Ada, OK.

Fountain, J.C., 1993. Extraction of Organic Pollutants using Enhanced Surfactant Flushing - Part II. Pilot Scale Field Trial at Corpus Christi, Texas. Project Summary. New York State Center for Hazardous Waste Management, SUNY Buffalo, 9 pp.

Fountain, J.C., 1992. Field Tests of Surfactant Flooding: Mobility Control of Dense Nonaqueous-Phase Liquids. In: Transport and Remediation of Subsurface Contaminants, edited by D.A. Sabatini and R. C. Knox. ACS Symposium Series 491, American Chemical Society, Washington, D.C., pp. 182-191.

Fountain, J.C., A. Klimek, M. Beikirch, and T. Middleton, 1991. The Use of Surfactants for In-Situ Extraction of Organic Chemicals from a Contaminated Aquifer, J. Hazard. Mater., 28: 295-311.

Freeze, R.A. and J.A. Cherry, 1979. Groundwater, Prentice Hall Inc., Englewood Cliffs, NJ.

Greff, R.A., E.A. Setzkorn, and W.D. Leslie, 1965. A Colorimetric Method for the Determination of Parts/Million of Nonionic Surfactants. J. Amer. Chem. Soc., 42:180-185.

Grim, R.E., 1968. Clay Mineralogy, 2nd Edition, McGraw-Hill Book Co. 
Jackson, R.E. and J.F. Pickens, 1993. Determining Location and Composition of Liquid Contaminants in Geologic Formations. U.S. Patent allowed, November 1993.

Jackson, R.E., 1993. Surfactant-Enhanced Remediation of DNAPL Zones in Granular Aquifer Systems. Remediation 4(1):77-91.

Jackson, R.E. and R.J. Patterson, 1982. Interpretation of $\mathrm{pH}$ and Eh Trends in a FluvialSand Aquifer System. Water Resources Research 18(4): 1255-1268.

Johnson, R.L. and J.F. Pankow, 1992. Dissolution of Dense Chlorinated Solvents into Groundwater. 2: Source Functions for Pools of Solvents. Environmental Science and Technology 26(5):896-901.

Kueper, B.H., 1991. The Occurrence of Dense, Non-Aqueous Phase Liquids in the Subsurface at the Paducah Gaseous Diffusion Plant. KY/ER/Sub/0815-1015/91/2. Martin Marietta Energy Systems Inc., Paducah, KY, 26 pp.

Lake, L., 1989. Enhanced Oil Recovery. Prentice Hall, Englewood Cliffs, NJ.

McConnell, C.L., D. Numbere, E. Wahidiyat, and A. Erkal, 1994. Determining TCE Distribution and Mobility at the DOE Paducah Gaseous Diffusion Plant without Direct Tracing. Abstract, NGWA Conference on Petroleum Hydrocarbons and Organic Chemicals, Houston, Texas.

Mackay, D.M. and J.A. Cherry, 1989. Groundwater Contamination: Pump-and-Treat Remediation. Environ. Sci. Technol. 23(6):630-636.

Palmer, C. D. and Fish, W. 1992. Chemical Enhancements to Pump and Treat Remediation. EPA/540/S-92/001.

Pennell, K.D., M. Jin, L.M. Abriola, and G.A. Pope, 1994. Surfactant-Enhanced Remediation of Soil Columns Contaminated by Residual Tetrachloroethylene. J. Contaminant Hydrology, 16:35-53.

Phillips, B.E., 1992. Geology of the UF $_{6}$ Cylinder Drop Test Area and the C-400 Trichloroethylene Leak Site at the Paducah Gaseous Diffusion Plant, Paducah, Kentucky. Unpublished report, Environmental Restoration Division, Martin Marietta Energy Systems Inc., Paducah, KY.

Rosen, M.J., 1989. Surfactants and Interfacial Phenomena. 2nd Edition, John Wiley \& Sons, New York. 
Saad, N., 1989. Field Scale Simulations of Chemical Flooding. Ph.D. Dissertation, The University of Texas at Austin, Austin, Texas.

Schwille, F., 1988. Dense Chlorinated Solvents in Porous and Fractured Media. Model Experiments. Lewis Surfactants and Interfacial Phenomena.Publishers English Language Edition, translated by J.F. Pankow, Chelsea, Michigan.

Swisher, R.D., 1987. Surfactant Biodegradation, 2nd Edition, Marcel Dekker, Inc. 
TABLES

112504-2 
Table 2.1: HLB Determination for TCE, PCE, and CTET, Using Tergitol Series (Secondary Linear Alcohol Ethoxylates)

\begin{tabular}{|c|c|c|c|c|}
\hline Surfactant No. & HLB & $\begin{array}{l}\text { TCE } \\
\text { Ppm }\end{array}$ & $\begin{array}{l}\text { PCE } \\
\text { PPI }\end{array}$ & $\begin{array}{l}\text { CTET } \\
\text { ppm }\end{array}$ \\
\hline 133 & 12.4 & & 1,450 & 1,376 \\
\hline 134 & 13.3 & 6,250 & $22,548^{*}$ & 12,220 \\
\hline 135 & 14.7 & $13,322^{*}$ & 5,792 & $17,876^{*}$ \\
\hline 136 & 15.6 & 6,224 & 2,770 & 8,173 \\
\hline 137 & 16.4 & 7,362 & 2,516 & 4,451 \\
\hline 138 & 17.5 & 3,701 & & 1,701 \\
\hline 139 & 18.0 & 2,606 & & \\
\hline
\end{tabular}

* HLB for each compound 
Table 2.2: Solubilization Results for TCE, PCE and CTET in Nonionic Surfactants

\begin{tabular}{|c|c|c|c|c|c|}
\hline $\begin{array}{l}\text { Surfactant } \\
\mathrm{No}\end{array}$ & Surfactant Name. & $\mathrm{HLB}$ & $\begin{array}{l}\text { TCE } \\
\text { (ppm) }\end{array}$ & $\begin{array}{l}\text { PCE } \\
(\text { ppm) }\end{array}$ & $\begin{array}{l}\text { CTET } \\
\text { (ppm) }\end{array}$ \\
\hline $3 / 4$ & POE C12-C15 Linear Alcohol & 14.8 & 3,031 & & 6,308 \\
\hline 9 & Ethoxylated Alcohol & 13 & 3,247 & 11,624 & 2,173 \\
\hline $9 / 10$ & Ethoxylated Alcohol & 14.8 & 2,020 & & 4,571 \\
\hline 10 & Ethoxylated Alcohol & 15.0 & 2,777 & & 3,692 \\
\hline 18 & Sorbitan Monooleate POE 20 & 15.0 & 16,157 & 6,023 & 12,509 \\
\hline 24 & Tridecyl Alcohol POE 12 & 14.5 & 1,602 & & 5,913 \\
\hline 25 & Linear Alcohol Ethoxylate & 14.4 & 3,367 & & 7,513 \\
\hline 37 & PEG Monolaurate & 13.6 & 3,785 & 23,447 & 21,071 \\
\hline $38 / 39$ & PEG Monolaurate & 14.8 & 10,620 & & 3,305 \\
\hline $38 / 39$ & PEG Monolaurate & 14.0 & 1,694 & & \\
\hline 60 & Sorbitan Monooleate POE 20 & 15.0 & 16,338 & 6,734 & 10,595 \\
\hline 121 & PEG 25 Soya Sterol & 17.0 & 29,627 & 7,783 & 19,748 \\
\hline 133 & C11-C15 Secondary Alcohol & 12.4 & & 1,450 & 1,376 \\
\hline 134 & C11-C15 Secondary Alcohol & 13.3 & 6,250 & 22,548 & 12,220 \\
\hline 135 & C11-C15 Secondary Alcohol & 14.7 & 13,322 & 5,792 & 17,876 \\
\hline 136 & C11-C15 Secondary Alcohol & 15.6 & 6,224 & 2,770 & 8,173 \\
\hline 137 & C11-C15 Secondary Alcohol & 16.4 & 7,362 & 2,516 & 4,451 \\
\hline 138 & C11-C15 Secondary Alcohol & 17.5 & 3,701 & & 1,701 \\
\hline 139 & C11-C15 Secondary Alcohol & 18.0 & 2,606 & & \\
\hline $144 / 145$ & 2,6,8 Trimethyl-4 Nonanol & 14.8 & 9,638 & & 6,902 \\
\hline 151 & Nonylphenyl Ethoxylate & 13.5 & 8,407 & 19,063 & 26,018 \\
\hline 154 & POE 7 Oleamide & 14.0 & 18,118 & 32,066 & 36,850 \\
\hline 164 & Octylphenol/Polyethoxy Ethanol & 13.5 & & 9,573 & \\
\hline $170 / 172$ & PEG-20/40 Lanolin Alcohol & 14.9 & 14,669 & & 4,355 \\
\hline 185 & Block Copolymer & $12-18$ & 4,319 & & \\
\hline 213 & PEG 1100 Castor Oil & & 38,358 & 11,396 & 21,187 \\
\hline $234 / 235$ & POE 10/20 Cetyl Ether & 14.9 & 6,674 & & 6,750 \\
\hline 271 & 12 POE Nonylphenol & 14.1 & 14,367 & 5,916 & \\
\hline 272 & 8 POE Nonlyphenol & 12.4 & 1,535 & 534 & \\
\hline
\end{tabular}


Table 2.3: Solubilization Results for TCE, PCE and CTET in Anionic Surfactants

\begin{tabular}{|c|c|c|c|c|}
\hline Surfactant & Surfactant Name & $\frac{\text { TCE }}{(p p m)}$ & $\begin{array}{c}\text { PCE } \\
\text { (ppm) }\end{array}$ & $\begin{array}{l}\text { CTET } \\
\text { (ppm) }\end{array}$ \\
\hline 14 & Aliphatic Phosphate Ester & 13,579 & 1,872 & 7,748 \\
\hline 22 & Phosphated Alkyl Ethoxy K-salt & 6,529 & 732 & 2,843 \\
\hline 31 & Na Dodecylbenzene Sulfonate & 4,339 & 773 & 2,154 \\
\hline 32 & C12-C13 Alcohol Ethoxysulfate & 3,737 & 584 & 2,589 \\
\hline 41 & Aliphatic Phosphate Ester & 8,289 & 863 & 4,896 \\
\hline 45 & POE Fatty Alcohol Phosphate Ester & 7,346 & 1,470 & 7,204 \\
\hline 54 & Phosphate Ester & & 4,472 & 12,253 \\
\hline 57 & Sulfate & & 486 & 2,750 \\
\hline 62 & Phosphate Ester & 4,816 & 5,083 & 23,765 \\
\hline 67 & Anionic/Nonionic Blend & 8,668 & $\begin{array}{l}9,322 \\
8,429 \\
\end{array}$ & 22,452 \\
\hline 72 & Sulfonate/ POE Ether Blend & 15,801 & $\begin{array}{l}9,940 \\
9,809 \\
\end{array}$ & 29,716 \\
\hline 78 & Cyclic Carboxylated Amide & 3,261 & 1,752 & 5,164 \\
\hline 109 & Na Dioctyl Sulfosuccinate & 3,800 & 3,911 & 8,302 \\
\hline 110 & Alkylaryl Polyoxyl Carboxylate & 2,711 & 19,688 & \\
\hline 111 & Alkylaryl Polyoxyl Carboxylate & 1,815 & 1,450 & 3,317 \\
\hline 112 & Alkyl Phenoxyl Ether Sulfate & 2,688 & & 2,732 \\
\hline 113 & Phosphate Ester & 4,526 & 2,490 & 6,055 \\
\hline 118 & $\mathrm{Na} \mathrm{C14-C16}$ Olefin Sulfonate & 3,337 & 758 & 2,176 \\
\hline 119 & Alkyl Aryl Sulfonate Isopropylamine & 19,976 & 3,704 & 26,125 \\
\hline 128 & Aliphatic Phosphate Ester & 27,284 & $\begin{array}{l}16,594 \\
12,089\end{array}$ & 23,279 \\
\hline 177 & Alkyl Aryl Sulfonate/ Nonionic Blend & 21,515 & 15,070 & 25,422 \\
\hline 193 & Benzene, 1,1-oxybis Tetrapropylene Sulfonate & 3,695 & 1,590 & 2,029 \\
\hline 194 & DiNa Dihexa/Hexadecyl Diphenol Disulfonate & 3,592 & 2,180 & 1,800 \\
\hline 195 & Linear Alkylbenzene Sulfonate & 7,411 & 2,001 & 5,745 \\
\hline
\end{tabular}


Table 2.3 (continued): Solubilization Results for TCE, PCE and CTET in Anionic Surfactants

\begin{tabular}{|c|c|c|c|c|}
\hline Surfactant & Surfactant Name & $\begin{array}{l}\text { TCE } \\
(\mathrm{ppm})\end{array}$ & $\begin{array}{l}\text { PCE } \\
(\text { ppm) }\end{array}$ & $\begin{array}{l}\text { 9teT } \\
(p p m)\end{array}$ \\
\hline 196 & Alpha Olefin Sulfonate & 6,189 & 2,226 & 7,872 \\
\hline 197 & Alpha Olefin Sulfonate & 2,298 & 1,197 & 4,959 \\
\hline 198 & Alkyl Aryl Sulfonate & & 284 & 2,414 \\
\hline 199 & Amine Alkylbenzene Sulfonate & 4,154 & $\begin{array}{l}11,078 \\
10,598\end{array}$ & 19,773 \\
\hline 200 & NH3 Alcohol POE(4) Sulfate & 4,469 & 1,057 & 3,312 \\
\hline $205^{\circ}$ & Na Alkyl Sulfonate & 2,891 & 617 & 2,137 \\
\hline 206 & $\mathrm{Na}$ Ethoxylated Alcohol Sulfate & 2,451 & 380 & 1,216 \\
\hline 207 & Na Alkyl Aryl Sulfonate & 2,848 & 494 & 1,900 \\
\hline 208 & Na Alkyl Diphenyl Oxide & $1,770^{(1)}$ & & 2,110 \\
\hline 214 & Na Alkyl Ether Sulfonate & 4,321 & 939 & 2,285 \\
\hline 215 & Na Alkyl Ether Sulfonate & 1,712 & 316 & 2,444 \\
\hline 222 & Dodecyl Benzene Sulfonate & 3,574 & 2,040 & 1,473 \\
\hline 223 & Dodecyl Benzene Sulfonate & 2,358 & 374 & 2,656 \\
\hline 242 & Sulfonated Castor Oil & 10,721 & 6,411 & 7,652 \\
\hline 243 & Natural and Synthetic Sulfonate Blend & 10,475 & 2,636 & 7,217 \\
\hline 244 & Na POE Nonylphenol Sulfate & 3,634 & 378 & 3,085 \\
\hline 245 & $\mathrm{Na}$ Sulfonate of Coconut Oil & 3,578 & 413 & 2,765 \\
\hline 246 & NH3 POE Alcohol Sulfate & 3,464 & 559 & 1,636 \\
\hline 247 & Di-Na Laureth sulfosuccinate & & 1,293 & 2,595 \\
\hline 248 & Sulfated Ester & 3,857 & 624 & 2,681 \\
\hline 249 & Na Sulfated Ester & 22,996 & 3,636 & 11,802 \\
\hline 250 & Sulfated Castor Oil & 14,382 & 4,243 & 8,451 \\
\hline 251 & Sulfated Castor Oil & & & 9,065 \\
\hline
\end{tabular}


Table 2.3 (continued): Solubilization Results for TCE, PCE and CTET in Anionic Surfactants

\begin{tabular}{|c|c|c|c|c|}
\hline Surfactant & Surfactant Name & $\begin{array}{l}\text { TCE } \\
\text { (ppin) }\end{array}$ & $\begin{array}{l}\mathrm{PCE} \\
(\mathrm{ppm})\end{array}$ & $\begin{array}{l}\text { (T) } \\
(\mathbf{p p m}) \\
\end{array}$ \\
\hline 252 & Sulfated Vegetable Oils & & & 7,592 \\
\hline 253 & Sulfonated Tall Oil Fatty Acid & & 3,293 & 4,963 \\
\hline 254 & Sulfated Soybean Oil/Ester & & & 15,171 \\
\hline 255 & Sulfated Glycerol Trioleate & & & 14,895 \\
\hline 256 & Sulfated Castor Oil & 5,390 & 1,501 & 6,317 \\
\hline 257 & Sulfonate/Nonionic Blend & & & 11,921 \\
\hline 258 & Na Linear Alkylate Sulfonate & 4,659 & 2,914 & 4,510 \\
\hline 260 & Alpha Sulfo Methyl Ester & 1,443 & 397 & \\
\hline 261 & C10 Alpha Olefin Sulfonate & 1,854 & 659 & \\
\hline 262 & Linear Alkylaryl Na Sulfonate & 4,504 & 1,312 & \\
\hline 264 & Alkyl Ether Sulfate & 2,448 & 1,051 & \\
\hline 266 & Cetyl/Steryl Alcohol \& Fatty Alcohol Sulfate & & 744 & \\
\hline 267 & Sulfonate & 1,704 & 1,720 & \\
\hline 268 & Sulfated Castor Oil & 7,006 & 7,134 & \\
\hline 269 & $\begin{array}{l}\text { Na C14-C16 Olefin Sulfonate/Na Laureth } \\
\text { Sulfate/Lauramide DEA }\end{array}$ & 5,876 & 2,111 & \\
\hline 270 & $\begin{array}{l}\text { Sodium Lauryl Sulfoacetate/ Di-sodium } \\
\text { Laureth }\end{array}$ & 2,757 & 888 & \\
\hline 273 & Na 1-Octane Sulfonate & 6,293 & 466 & \\
\hline 274 & Sulfated Castor Oil & 2,961 & 3,712 & \\
\hline 275 & Ammonia Neutralized Sulfated Oleic Acid & 8,765 & 6,703 & \\
\hline 277 & Sodium Tridecyl Sulfosuccinate & & 908 & \\
\hline 278 & $\begin{array}{l}\text { Sodium Oleoylisopropanolamide } \\
\text { Sulfosuccinate }\end{array}$ & 827 & 906 & \\
\hline
\end{tabular}


Table 2.3 (continued): Solubilization Results for TCE, PCE and CTET in Anionic Surfactants

\begin{tabular}{|c|c|c|c|c|}
\hline Surfactant? & Surfactant Name & (ppri) & $(\mathrm{ppm})$ & (ppm) \\
\hline 279 & Sodium Dioctyl Sulfosuccinate & 6,088 & 4,277 & \\
\hline 280 & Sodium Ethoxylated Alcohol Sulfosuccinate & 1,598 & 418 & \\
\hline 281 & $\begin{array}{l}\text { Sodium Oleoylisopropanolamide } \\
\text { Sulfosuccinate }\end{array}$ & 2,655 & 992 & \\
\hline 282 & Sodium Octyl Sulfate & 1,828 & 363 & \\
\hline 283 & Sodium Laureth Sulfate & 4,909 & 1,710 & \\
\hline 284 & $\begin{array}{l}\text { Di-sodium Mono-oleamido PEG-2 } \\
\text { sulfosuccinate }\end{array}$ & 1,989 & 653 & \\
\hline 285 & Sodium Myreth Sulfate & 5,147 & 1,482 & \\
\hline 286 & Sodium $n$-decyl Sulfate & 1,616 & 228 & \\
\hline 287 & Sodium 2-ethylhexyl Sulfate & 2,129 & 625 & \\
\hline 288 & $\begin{array}{l}\text { Sodium Dioctyl Sulfosuccinate/ } \\
\text { propylene Glycol }\end{array}$ & 5,444 & $5,200^{(2)}$ & \\
\hline 289 & Sodium Dicyclohexyl Sulfosuccinate & 1,370 & 295 & \\
\hline 290 & Sodium Dihexyl Sulfosuccinate & 1,000 & 300 & \\
\hline 291 & Sodium Diisobutyl Sulfosuccinate & 1,208 & 486 & \\
\hline 292 & Octylphenol Ethoxylate Sulfonate & 3,114 & 796 & \\
\hline 293 & C12-C15 Ethoxylate (EO 15) Sulfonate & 2,418 & 854 & \\
\hline 294 & C12-C15 Ethoxylate (EO 7) Sulfonate & 2,563 & 927 & \\
\hline 295 & $\begin{array}{l}\text { Ammonium Nonylphenoxypoly (ethleneoxy) } \\
\text { Ethanol Sulfate }\end{array}$ & 4,659 & & \\
\hline
\end{tabular}

(1) Surf 208 incorrectly reported as 1,170 previously.

(2) Surf $2885200 \mathrm{ppm}$ is average of duplicate analyses of $5420 \mathrm{ppm}$ and $4980 \mathrm{ppm}$. 
Table 2.4: Percent TCE and PCE Solubilized to Percent TCE and PCE in DNAPL Mixtures

\begin{tabular}{|c|c|c|c|}
\hline Surfactant No. & TCEPCE in Mixture & $\%$ TCE & $\%$ PCE \\
\hline \multirow{4}{*}{$\begin{array}{c}18 \\
\text { Sorbitan } \\
\text { Monooleate }\end{array}$} & $90: 10$ & 89.1 & 10.9 \\
\hline & $75: 25$ & 78.7 & 21.3 \\
\hline & $50: 50$ & 57.8 & 42.2 \\
\hline & $25: 75$ & 30.9 & 69.1 \\
\hline \multirow{4}{*}{$\begin{array}{c}154 \\
\text { POE } 7 \\
\text { Oleamide }\end{array}$} & $90: 10$ & 90.5 & 9.5 \\
\hline & $75: 25$ & 77.2 & 22.8 \\
\hline & $50: 50$ & 51.3 & 48.7 \\
\hline & $25: 75$ & 26.3 & 73.7 \\
\hline \multirow{4}{*}{$\begin{array}{c}135 \\
\text { C11-C15 } \\
\text { Secondary } \\
\text { Alcohol }\end{array}$} & $90: 10$ & 91.2 & 8.8 \\
\hline & $75: 25$ & 79.0 & 21.0 \\
\hline & 50:50 & 52.6 & 47.4 \\
\hline & $25: 75$ & 27.9 & 72.1 \\
\hline
\end{tabular}


Table 2.5: Retardation Factors for Selected Surfactants

\begin{tabular}{|c|c|c|c|c|}
\hline Surfactant. & $\begin{array}{l}\text { Natural soil } \\
\text { with } 10 \% \% \\
\text { smectite } 1 \%\end{array}$ & $\begin{array}{l}\text { Na } \\
\text { smectite } \\
\text { mixtures } \\
\text { (i) }\end{array}$ & 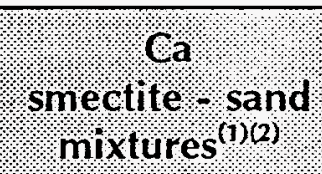 & smectite s sand \\
\hline 18 & 22.05 & $\begin{array}{l}1 \%=1.51 \\
5 \%=13.68 \\
10 \%=20.70 \\
20 \%=19.98\end{array}$ & $\begin{array}{l}1 \%=1.48 \\
5 \%=5.95 \\
10 \%=12.09 \\
20 \%=20.80\end{array}$ & \\
\hline 60 & & & & 2.22 \\
\hline 64 & 20.71 & & & \\
\hline 135 & & & & 3.54 \\
\hline 154 & & & & 4.33 \\
\hline 161 & 21.68 & & & \\
\hline
\end{tabular}

(1) Studies other than DOE.

(2) Percentages indicate fraction of clay in mixture. 
Table 2.6: Interfacial Tension Measurements Between $1 \%$ Surfactant Solutions and PCE, TCE and CTET

\begin{tabular}{|c|c|c|c|}
\hline $\begin{array}{l}\text { Surfactant" No: } \\
\text { and Standards }\end{array}$ & $\begin{array}{l}\text { PCE IFT" } \\
\text { (dynes/cm) }\end{array}$ & $\begin{array}{l}\text { TCE IFT) } \\
\text { (dynes/cm) }\end{array}$ & $\begin{array}{l}\text { CTET IFT } \\
\text { (dynes/cm) }\end{array}$ \\
\hline Referenced value with D.I. water & 44.40 & 34.50 & 45.00 \\
\hline Measured value with D.I. water & 44.43 & 27.49 & 43.48 \\
\hline 18 & 11.08 & 11.67 & 11.10 \\
\hline 37 & 8.86 & $15.85^{(2)}$ & 11.58 \\
\hline 60 & 10.72 & 11.26 & 10.72 \\
\hline 121 & 13.64 & 14.36 & 14.82 \\
\hline 134 & 6.08 & $15.26^{(2)}$ & 10.15 \\
\hline 135 & 5.03 & $14.96^{(2)}$ & 7.01 \\
\hline 151 & 4.08 & $18.55^{(2)}$ & 8.12 \\
\hline 154 & 9.54 & $15.6^{(2)}$ & 13.0 \\
\hline 194 & 10.20 & 9.40 & 11.43 \\
\hline 199 & $1.67^{\mathrm{e}}$ & $1.64^{(2)}$ & $1.03^{\mathrm{e}}$ \\
\hline 213 & 16.32 & 13.16 & 13.42 \\
\hline 222 & 6.84 & 7.04 & 7.23 \\
\hline 242 & 13.06 & 9.9 & 13.62 \\
\hline 249 & 7.62 & 2.46 & $6.88^{e}$ \\
\hline
\end{tabular}

(1) See Tables 2.2 and 2.3 for surfactant names.

(2) An emulsion was present at the interface. 
Table 2.7: Surfactant Critical Micellar Concentration

\begin{tabular}{|c|c|}
\hline 7. Surfactant No. $: ~$ & Surfactant (Volume \%) \\
\hline 18 & 0.012 \\
\hline 135 & 0.011 \\
\hline
\end{tabular}

Table 2.8: Surfactant Solution Viscosities

\begin{tabular}{|l|l|}
\hline 70 & $\begin{array}{c}\text { Viscosity } \\
(\mathrm{kg} / \mathrm{m}-\mathrm{s})\end{array}$ \\
\hline Distilled water & $8.95 \times 10^{-4}$ \\
\hline $1 \%$ Solution No. 18 & $9.38 \times 10^{-4}$ \\
\hline $2 \%$ Solution No. 18 & $1.01 \times 10^{-3}$ \\
\hline $1 \%$ Solution No. 135 & $9.79 \times 10^{-4}$ \\
\hline $2 \%$ Solution No. 135 & $1.05 \times 10^{-3}$ \\
\hline $1 \%$ Solution No. 154 & $2.18 \times 10^{-3}$ \\
\hline $2 \%$ Solution No. 154 & $7.06 \times 10^{-3}$ \\
\hline
\end{tabular}


Table 2.9: Surfactant Solubilization Kinetics

\begin{tabular}{|c|c|c|c|c|}
\hline Surfactant & ml & $\begin{array}{l}\text { Pore } \\
\text { Volumes }\end{array}$ & $\mathrm{ppm} T \mathrm{TCE}$ & $\begin{array}{l}\text { Average MAC } \\
\text { ppm TCE }\end{array}$ \\
\hline $18 \mathrm{~A}$ & 40 & 1 & 3,526 & \\
\hline $18 \mathrm{~A}$ & 57 & 1.4 & 12,620 & 13,136 \\
\hline $18 B$ & 54 & 1 & 3,589 & \\
\hline $18 B$ & 66 & 1.2 & 13,155 & 13,605 \\
\hline 135 & 56.5 & 1 & 806 & \\
\hline 135 & 79.5 & 1.4 & 3,923 & 3,111 \\
\hline 154 & 52 & 1 & 2,499 & \\
\hline 154 & 74.5 & 1.4 & 9,746 & 10,796 \\
\hline
\end{tabular}

* The average MAC value as determined once TCE ppm values had reached a plateau.

Table 2.10: Solubilization Data for $1 \%$ Sorbitan Monooleate Solutions

\begin{tabular}{|c|c|c|c|}
\hline Surfactant No: & TCE ppm & PCE ppm & CTET ppm \\
\hline 18 & 16157 & 6023 & 12509 \\
\hline 60 & 16338 & 6734 & 10595 \\
\hline 64 & $15407^{*}$ & $5161^{*}$ & \\
\hline
\end{tabular}

* From studies other than DOE 
Table 2.11: Interfacial Tension (IFT) Measurements Between $1 \%$ Sorbitan Monooleate Solutions and TCE, PCE, or CTET

\begin{tabular}{|c|c|c|c|}
\hline $\begin{array}{l}\text { Surfactant No: } \\
\text { \% } 7 \text { and Standards. }\end{array}$ & (dynes/cm) & (dynes/cm) & $\begin{array}{l}\text { CTET IFT } \\
\text { (dynes/ } \mathrm{cm} \text { ) }\end{array}$ \\
\hline $\begin{array}{l}\text { Referenced value with } \\
\text { D.I. water }\end{array}$ & 34.50 & 44.40 & 45.00 \\
\hline $\begin{array}{l}\text { Measured value with D.I. } \\
\text { water }\end{array}$ & 27.49 & 44.43 & 43.48 \\
\hline 18 & 11.67 & 11.08 & 11.10 \\
\hline 60 & 11.26 & 10.72 & 10.72 \\
\hline
\end{tabular}

Table 2.12: Viscosity of Sorbitan Monooleates (No. 18)

\begin{tabular}{|c|c|}
\hline 70 & Viscosity \\
\hline (kg/m-s)
\end{tabular}


Table 2.13: Retardation Factors for Sorbitan Monooleates

\begin{tabular}{|c|c|c|c|c|}
\hline $\begin{array}{l}\text { Surfactant } \\
\text { number }\end{array}$ & $\begin{array}{l}\text { Natural soil } \\
\text { with } 10 \% \% \text {. } \\
\text { smectitell }\end{array}$ & 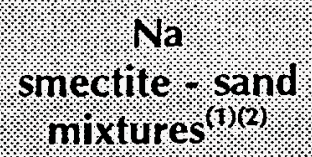 & 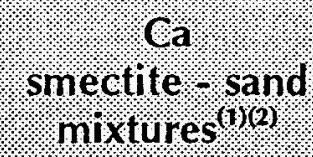 & $\begin{array}{l}3 \% \text { illitel } \\
\text { smectite sand } \\
\text { mixture }\end{array}$ \\
\hline 18 & 22.05 & $\begin{array}{l}1 \%=1.51 \\
5 \%=13.68 \\
10 \%=20.70 \\
20 \%=19.98\end{array}$ & $\begin{array}{l}1 \%=1.48 \\
5 \%=5.95 \\
10 \%=12.09 \\
20 \%=20.80\end{array}$ & \\
\hline 60 & & & & 2.22 \\
\hline 64 & 20.71 & & & \\
\hline 161 & 21.68 & & & \\
\hline
\end{tabular}

(1) Studies other than DOE.

(2) Percentages indicate fraction of clay in mixture. 
Table 3.1: Hydrostratigraphic Data for MW-156 from Phillips (1992)

\begin{tabular}{|c|c|c|}
\hline $\begin{array}{l}\text { Hydrogeologic } \\
\text { Unit }\end{array}$ & $\begin{array}{l}\text { Thickness } \\
\text { (feet) }\end{array}$ & Description \\
\hline HU1 & 21 & Loess; mainly yellow-brown clay \\
\hline HU2 & 16 & Gravel unit, fining upward into a sandy clay \\
\hline HU3 & 17 & Sandy clay \\
\hline HU4 & 6.5 & Sand, fine- to medium-grained \\
\hline HU5 & 32 & $\begin{array}{l}\text { Regional Gravel Aquifer; sandy gravel fining upward } \\
\text { into a gravelly, fine- to medium-grained sand }\end{array}$ \\
\hline - & ? & McNairy Fm.; sandy clay \\
\hline
\end{tabular}

Table 3.2: TCE Contamination in $\mathrm{mg} / \mathrm{L}$ in the WMU-11 Monitor Well Nest

\begin{tabular}{|c|c|c|c|}
\hline $\begin{array}{l}: \\
\text { Date } \\
\text { (month: } \\
\text { and year) }\end{array}$ & : : Screened Intervall: & 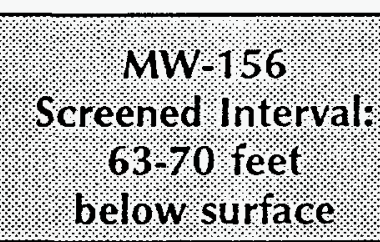 & 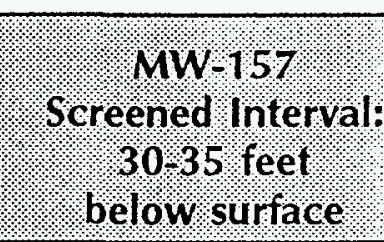 \\
\hline 3.91 & 1.8 & $>300$ & $>900$ \\
\hline 7.91 & 2.4 & 550 & 640 \\
\hline 6.93 & -- & 460 & -- \\
\hline 7.93 & 2.3 & 400 & 100 \\
\hline 8.93 & 1.8 & 380 & 160 \\
\hline 9.93 & 1.9 & 400 & 530 \\
\hline 10.93 & 2.2 & 380 & 550 \\
\hline 11.93 & 1.9 & 370 & 110 \\
\hline
\end{tabular}


Table 3.3: Model Parameters

\begin{tabular}{|c|c|}
\hline Model Parameter : & Value. \\
\hline Grid Dimensions & $750 \mathrm{ft}$ long, $1 \mathrm{ft}$ wide, $54 \mathrm{ft}$ thick \\
\hline Grid Blocks & $\begin{array}{l}\text { Scenario A: } 25 \times 27 \\
\text { Scenario B: } 25 \times 32\end{array}$ \\
\hline Volume of TCE & 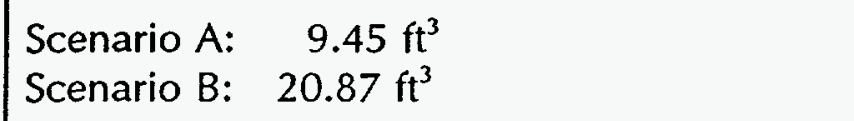 \\
\hline Porosity & 0.35 \\
\hline Hydraulic Conductivity & $\begin{array}{l}\text { Lacustrine Units }-2 \times 10^{-5} \mathrm{~cm} / \mathrm{s} \\
3100 \mathrm{md} \text { Upper RGA }-3 \times 10^{-3} \mathrm{~cm} / \mathrm{s} \\
4132 \mathrm{md} \text { Lower RGA }-4 \times 10^{-3} \mathrm{~cm} / \mathrm{s} \\
1.0 \mathrm{md} \text { McNairy Formation }-1 \times 10^{-6} \mathrm{~cm} / \mathrm{s}\end{array}$ \\
\hline$K / K_{h}$ & 0.1 \\
\hline Hydraulic Gradient & $0.00175 \mathrm{ft} / \mathrm{ft}$ \\
\hline Recharge Rate & $4.7 \mathrm{in} / \mathrm{yr}$ \\
\hline Longitudinal Dispersivity & $1.0 \mathrm{ft}$ \\
\hline Transverse Dispersivity & $0.2 \mathrm{ft}$ \\
\hline Residual Saturation of Water & 0.35 \\
\hline Residual Saturation of TCE & $\begin{array}{l}0.20 \text { in all blocks except for } 0.40 \text { for bottom } \\
\text { of DNAPL source in Scenario B }\end{array}$ \\
\hline Model Dip & $0.0 \mathrm{ft} / \mathrm{ft}$ \\
\hline
\end{tabular}


Table 3.4: Comparison of Averaged Concentrations

\begin{tabular}{|c|c|c|c|c|}
\hline $\begin{array}{l}\text { Well } \\
\text { Number }\end{array}$ & Value (mg/l) & $\begin{array}{l}\text { Measured } \\
\text { Value* } \\
\text { (vollvol) }\end{array}$ & $\begin{array}{l}\text { Scenario A } \\
\text { : Value } \\
\text { (vol/voll }\end{array}$ & $\begin{array}{l}\text { Scenario B } \\
\text { 9 Value } \\
\text { (vol/vol) }\end{array}$ \\
\hline 155 & 2.5 & $1.7 \times 10^{-6}$ & $4.71 \times 10^{-6}$ & $6.7 \times 10^{-4}$ \\
\hline 156 & 320 & $2.2 \times 10^{-4}$ & $3.36 \times 10^{-4}$ & $3.84 \times 10^{-4}$ \\
\hline 178 & 110 & $7.5 \times 10^{-5}$ & $3.62 \times 10^{-5}$ & $4.0 \times 10^{-5}$ \\
\hline
\end{tabular}

* Assumes density of TCE $=1,460 \mathrm{~kg} / \mathrm{m}^{3}$. 
Table 5.1: Results of Field Analyses for MW-156

\begin{tabular}{|c|c|c|c|c|c|c|c|}
\hline $\begin{array}{l}\text { Sample } \\
\text { Number }\end{array}$ & $\begin{array}{l}\text { Day of } \\
\text { Month }\end{array}$ & $\begin{array}{l}\text { Hour } \\
\text { of Day }\end{array}$ & $\begin{array}{c}\text { Time } \\
\text { Since } \\
\text { Extraction } \\
\text { Began } \\
\text { (days) }\end{array}$ & $\begin{array}{l}\text { Avg. } \\
\text { TCE } \\
\text { Conc. } \\
\text { Data } \\
(\mathrm{mg} / \mathrm{L})\end{array}$ & $\begin{array}{l}\text { Surfactant } \\
\text { Conc. } \\
\text { Data } \\
\text { (\% by wt) }\end{array}$ & $\begin{array}{l}\text { Surfactant } \\
\text { Conc. } \\
\text { Data } \\
\text { (\% by vol) }\end{array}$ & $\begin{array}{l}\text { Temp. } \\
\text { ('C) }\end{array}$ \\
\hline 1 & 3 & 11.5 & -6.10 & 353 & & & \\
\hline 4 & 3 & 12.5 & -6.06 & 367 & & & 22 \\
\hline 5 & 3 & 13.5 & -6.02 & 350 & & & 23 \\
\hline 7 & 3 & 14.5 & -5.98 & 322 & & & \\
\hline 8 & 3 & 15.5 & -5.94 & 308 & & & \\
\hline 10 & 3 & 16.5 & -5.90 & 376 & & & \\
\hline 11 & 3 & 17.5 & -5.85 & 348 & & & \\
\hline 12 & 3 & 18.5 & -5.81 & 312 & & & \\
\hline 13 & 3 & 19.5 & -5.77 & 387 & & & \\
\hline 14 & 3 & 20.5 & -5.73 & 300 & & & \\
\hline 15 & 3 & 21.5 & -5.69 & 382 & & & \\
\hline 16 & 3 & 22.5 & -5.65 & 300 & & & 21 \\
\hline 17 & 3 & 23.5 & -5.60 & 356 & & & 21 \\
\hline 18 & 4 & 0.5 & -5.56 & 327 & & & 21 \\
\hline 19 & 4 & 1.5 & -5.52 & 392 & & & \\
\hline 20 & 4 & 2.5 & -5.48 & 359 & & & \\
\hline 24 & 5 & 18.75 & -3.80 & $<1$ & 1.14 & 1.04 & \\
\hline 25 & 6 & 7.83 & -3.26 & $<1$ & 1.15 & 1.06 & \\
\hline 30 & 7 & 11.17 & -2.12 & $<1$ & 1.12 & 1.03 & \\
\hline 32 & 7 & 15.17 & -1.95 & $<1$ & 1.12 & 1.03 & \\
\hline 35 & 8 & 11.25 & -1.11 & $<1$ & 1.13 & 1.04 & \\
\hline 37 & 8 & 16.5 & -0.90 & & 1.09 & 1.00 & \\
\hline 39 & 9 & 9.6 & -0.18 & $<1$ & 1.08 & 0.99 & \\
\hline 40 & 9 & 14.25 & 0.01 & $<1$ & 1.09 & 1.00 & \\
\hline 41 & 9 & 15 & 0.04 & 1 & 1.04 & 0.95 & \\
\hline 43 & 9 & 16 & 0.08 & 1 & 1.05 & 0.96 & \\
\hline 44 & 9 & 17 & 0.13 & 2 & 1.04 & 0.95 & \\
\hline 45 & 9 & 18 & 0.17 & 3 & & & \\
\hline 46 & 9 & 19 & 0.21 & 4 & 0.99 & 0.91 & 27 \\
\hline
\end{tabular}


Table 5.1 (continued): Results of Field Analyses for MW-156

\begin{tabular}{|c|c|c|c|c|c|c|c|}
\hline $\begin{array}{l}\text { Sample } \\
\text { Number }\end{array}$ & $\begin{array}{l}\text { Day of } \\
\text { Month }\end{array}$ & $\begin{array}{l}\text { Hour } \\
\text { of Day }\end{array}$ & $\begin{array}{c}\text { Time } \\
\text { Since } \\
\text { Extraction } \\
\text { Began } \\
\text { (days) }\end{array}$ & $\begin{array}{l}\text { Avg. } \\
\text { TCE } \\
\text { Conc. } \\
\text { Data } \\
(\mathrm{mg} / \mathrm{L})\end{array}$ & $\begin{array}{l}\text { Surfactant } \\
\text { Conc. } \\
\text { Data } \\
\text { (\% by wt) }\end{array}$ & $\begin{array}{l}\text { Surfactant } \\
\text { Conc. } \\
\text { Data } \\
\text { (\% by vol) }\end{array}$ & $\begin{array}{c}\text { Temp. } \\
\text { ('C) }\end{array}$ \\
\hline 48 & 9 & 20 & 0.25 & 4 & & & 27 \\
\hline 49 & 9 & 21 & 0.29 & 5 & 0.96 & 0.88 & 26 \\
\hline 50 & 9 & 22 & 0.33 & 6 & & & 26 \\
\hline 51 & 9 & 23 & 0.38 & 6 & & & 26 \\
\hline 52 & 10 & 0 & 0.42 & 7 & 0.92 & 0.84 & 26 \\
\hline 53 & 10 & 1 & 0.46 & 7 & & & 25 \\
\hline 54 & 10 & 2 & 0.50 & 8 & 0.87 & 0.80 & 25 \\
\hline 55 & 10 & 3 & 0.54 & 8 & & & 25 \\
\hline 56 & 10 & 4 & 0.58 & 9 & 0.85 & 0.78 & 25 \\
\hline 57 & 10 & 5 & 0.63 & 11 & & & 25 \\
\hline 58 & 10 & 6 & 0.67 & 11 & & & 24 \\
\hline 59 & 10 & 7 & 0.71 & 9 & 0.78 & 0.72 & 24 \\
\hline 61 & 10 & 8 & 0.75 & 12 & 0.75 & 0.69 & \\
\hline 62 & 10 & 9 & 0.79 & 11 & & & \\
\hline 63 & 10 & 10 & 0.83 & 11 & & & \\
\hline 64 & 10 & 11 & 0.88 & 11 & 0.69 & 0.63 & \\
\hline 65 & 10 & 12 & 0.92 & 12 & & & \\
\hline 66 & 10 & 13 & 0.96 & 11 & & & \\
\hline 67 & 10 & 14 & 1.00 & 12 & 0.61 & 0.56 & \\
\hline 68 & 10 & 15 & 1.04 & 12 & & & \\
\hline 70 & 10 & 16 & 1.08 & 12 & 0.56 & 0.51 & \\
\hline 71 & 10 & 17 & 1.13 & 15 & & & 26 \\
\hline 72 & 10 & 18 & 1.17 & 14 & & & 25 \\
\hline 73 & 10 & 19 & 1.21 & 15 & 0.48 & 0.44 & 25 \\
\hline 76 & 10 & 22 & 1.33 & 15 & 0.39 & 0.36 & 24 \\
\hline 77 & 11 & 0 & 1.42 & 15 & & & 24 \\
\hline 78 & 11 & 1 & 1.46 & 20 & & & 23 \\
\hline 79 & 11 & 2 & 1.50 & 19 & 0.32 & 0.29 & 23 \\
\hline 80 & 11 & 3 & 1.54 & 24 & & & 23 \\
\hline
\end{tabular}


Table 5.1 (continued): Results of Field Analyses for MW-156

\begin{tabular}{|c|c|c|c|c|c|c|c|}
\hline $\begin{array}{l}\text { Sample } \\
\text { Number }\end{array}$ & $\begin{array}{l}\text { Day of } \\
\text { Month }\end{array}$ & $\begin{array}{l}\text { Hour } \\
\text { of Day }\end{array}$ & $\begin{array}{c}\text { Time } \\
\text { Since } \\
\text { Extraction } \\
\text { Began } \\
\text { (days) }\end{array}$ & $\begin{array}{l}\text { Avg. } \\
\text { TCE } \\
\text { Conc. } \\
\text { Data } \\
(\mathrm{mg} / \mathrm{L})\end{array}$ & $\begin{array}{l}\text { Surfactant } \\
\text { Conc. } \\
\text { Data } \\
\text { (\% by wt) }\end{array}$ & $\begin{array}{l}\text { Surfactant } \\
\text { Conc. } \\
\text { Data } \\
\text { (\% by vol) }\end{array}$ & $\begin{array}{c}\text { Temp. } \\
\text { ('C) }\end{array}$ \\
\hline 81 & 11 & 4 & 1.58 & 24 & & & 23 \\
\hline 82 & 11 & 5 & 1.63 & 27 & & & 23 \\
\hline 83 & 11 & 6 & 1.67 & 26 & 0.25 & 0.23 & 23 \\
\hline 84 & 11 & 7 & 1.71 & 29 & & & 23 \\
\hline 86 & 11 & 8 & 1.75 & 28 & & & 23 \\
\hline 87 & 11 & 9 & 1.79 & 28 & 0.22 & 0.20 & \\
\hline 88 & 11 & 10 & 1.83 & 29 & & & \\
\hline 89 & 11 & 11 & 1.88 & 28 & & & \\
\hline 90 & 11 & 12 & 1.92 & 28 & & & \\
\hline 91 & 11 & 13 & 1.96 & 31 & 0.17 & 0.16 & \\
\hline 92 & 11 & 14 & 2.00 & 32 & & & \\
\hline 93 & 11 & 15 & 2.04 & 34 & & & \\
\hline 95 & 11 & 16 & 2.08 & 36 & 0.15 & 0.14 & \\
\hline 96 & 11 & 17 & 2.13 & 43 & & & 24 \\
\hline 98 & 11 & 19 & 2.21 & 44 & & & 24 \\
\hline 100 & 11 & 21 & 2.29 & 41 & 0.11 & 0.10 & 23 \\
\hline 102 & 11 & 23 & 2.38 & 43 & & & 23 \\
\hline 105 & 12 & 2 & 2.50 & & 0.09 & 0.08 & 22 \\
\hline 107 & 12 & 4 & 2.58 & 50 & & & 22 \\
\hline 109 & 12 & 6 & 2.67 & 53 & 0.06 & 0.06 & 22 \\
\hline 110 & 12 & 7 & 2.71 & 57 & 0.099 & 0.09 & 22 \\
\hline 112 & 12 & 8 & 2.75 & 55 & & & 22 \\
\hline 114 & 12 & 10 & 2.83 & 54 & & & \\
\hline 115 & 12 & 11 & 2.88 & & 0.061 & 0.06 & \\
\hline 116 & 12 & 12 & 2.92 & 60 & & & \\
\hline 118 & 12 & 14 & 3.00 & 63 & & & \\
\hline 120 & 12 & 16 & 3.08 & 65 & 0.049 & 0.04 & 24 \\
\hline 122 & 12 & 17 & 3.13 & 71 & & & 24 \\
\hline 124 & 12 & 19 & 3.21 & 51 & & & 23 \\
\hline
\end{tabular}


Table 5.1 (continued): Results of Field Analyses for MW-156

\begin{tabular}{|c|c|c|c|c|c|c|c|}
\hline $\begin{array}{l}\text { Sample } \\
\text { Number }\end{array}$ & $\begin{array}{l}\text { Day of } \\
\text { Month }\end{array}$ & $\begin{array}{l}\text { Hour } \\
\text { of Day }\end{array}$ & $\begin{array}{c}\text { Time } \\
\text { Since } \\
\text { Extraction } \\
\text { Began } \\
\text { (days) }\end{array}$ & $\begin{array}{l}\text { Avg. } \\
\text { TCE } \\
\text { Conc. } \\
\text { Data } \\
(\mathrm{mg} / \mathrm{L})\end{array}$ & $\begin{array}{l}\text { Surfactant } \\
\text { Conc. } \\
\text { Data } \\
\text { (\% by wt) }\end{array}$ & $\begin{array}{l}\text { Surfactant } \\
\text { Conc. } \\
\text { Data } \\
\text { (\% by vol) }\end{array}$ & $\begin{array}{c}\text { Temp. } \\
\text { ('C) }\end{array}$ \\
\hline 125 & 12 & 20 & 3.25 & & 0.048 & 0.04 & 22.5 \\
\hline 127 & 12 & 22 & 3.33 & 60 & & & 23 \\
\hline 129 & 12 & 24 & 3.42 & 62 & & & 22 \\
\hline 130 & 13 & 1 & 3.46 & & 0.053 & 0.05 & 22 \\
\hline 131 & 13 & 2 & 3.50 & 65 & & & 21 \\
\hline 133 & 13 & 4 & 3.58 & 65. & & & 21 \\
\hline 135 & 13 & 6 & 3.67 & 67 & 0.045 & 0.04 & 21 \\
\hline 138 & 13 & 8 & 3.75 & 75 & & & 22 \\
\hline 140 & 13 & 10 & 3.83 & 73 & 0.039 & 0.04 & 23 \\
\hline 142 & 13 & 12 & 3.92 & 69 & & & \\
\hline 143 & 13 & 13 & 3.96 & 51 & & & 25 \\
\hline 144 & 13 & 14 & 4.00 & 80 & & & \\
\hline 145 & 13 & 15 & 4.04 & 64 & 0.028 & 0.03 & 24 \\
\hline 147 & 13 & 16 & 4.08 & 66 & & & 24 \\
\hline 149 & 13 & 18 & 4.17 & 71 & & & \\
\hline 150 & 13 & 19 & 4.21 & 81 & 0.03 & 0.03 & 22 \\
\hline 153 & 13 & 22 & 4.33 & 85 & & & 22 \\
\hline 154 & 14 & 3.33 & 4.56 & 103 & & & 21 \\
\hline 155 & 14 & 4.33 & 4.60 & & 0.015 & 0.014 & 21 \\
\hline 158 & 14 & 8 & 4.75 & 104 & & & 22 \\
\hline 159 & 14 & 10 & 4.83 & & 0.012 & 0.011 & 22 \\
\hline 160 & 14 & 12 & 4.92 & 101 & & & 22 \\
\hline 163 & 14 & 16 & 5.08 & 160 & & & 22 \\
\hline 164 & 14 & 18 & 5.17 & 158 & 0.01 & 0.009 & 22 \\
\hline 166 & 14 & 22 & 5.33 & 154 & & & 20 \\
\hline 167 & 15 & 7.5 & 5.73 & 207 & & & \\
\hline 169 & 15 & 9.15 & 5.80 & 209 & $<0.01$ & $<0.009$ & \\
\hline 171 & 15 & 13 & 5.96 & 196 & & & 22 \\
\hline 172 & 15 & 15 & 6.04 & & $<0.01$ & $<0.009$ & \\
\hline
\end{tabular}


Table 5.1 (continued): Results of Field Analyses for MW-156

\begin{tabular}{|c|c|c|c|c|c|c|c|}
\hline $\begin{array}{l}\text { Sample } \\
\text { Number }\end{array}$ & $\begin{array}{l}\text { Day of } \\
\text { Month }\end{array}$ & $\begin{array}{l}\text { Hour } \\
\text { of Day }\end{array}$ & $\begin{array}{c}\text { Time } \\
\text { Since } \\
\text { Extraction } \\
\text { Began } \\
\text { (days) }\end{array}$ & $\begin{array}{l}\text { Avg. } \\
\text { TCE } \\
\text { Conc. } \\
\text { Data } \\
(\mathrm{mg} / \mathrm{L})\end{array}$ & $\begin{array}{l}\text { Surfactant } \\
\text { Conc. } \\
\text { Data } \\
\text { (\% by wt) }\end{array}$ & $\begin{array}{l}\text { Surfactant } \\
\text { Conc. } \\
\text { Data } \\
\text { (\% by vol) }\end{array}$ & $\begin{array}{l}\text { Temp. } \\
\text { ('C) }\end{array}$ \\
\hline 174 & 15 & 17 & 6.13 & 218 & & & 21 \\
\hline 176 & 15 & 21 & 6.29 & 214 & & & 20 \\
\hline 178 & 16 & 7 & 6.71 & 230 & & & \\
\hline 180 & 16 & 11 & 6.88 & 246 & & & \\
\hline 182 & 16 & 15 & 7.04 & 225 & & & \\
\hline 184 & 16 & 19 & 7.21 & 250 & & & 21 \\
\hline 185 & 16 & 23 & 7.38 & 250 & & & 20 \\
\hline 187 & 17 & 7.5 & 7.73 & 250 & & & \\
\hline 188 & 17 & 11 & 7.88 & 262 & & & \\
\hline 190 & 17 & 15 & 8.04 & 236 & & & \\
\hline 192 & 17 & 19 & 8.21 & 281 & & & 21 \\
\hline 193 & 17 & 23 & 8.38 & 240 & & & \\
\hline 195 & 18 & 7.5 & 8.73 & 218 & & & \\
\hline 196 & 18 & 11.25 & 8.89 & 209 & & & \\
\hline 198 & 18 & 15 & 9.04 & 227 & & & \\
\hline 200 & 18 & 19 & 9.21 & & & & 21 \\
\hline 201 & 18 & 23 & 9.38 & & & & 20 \\
\hline 204 & 19 & 11 & 9.88 & 249 & & & 23 \\
\hline 208 & 19 & 19 & 10.21 & & & & 21 \\
\hline 209 & 19 & 23 & 10.38 & & & & 20 \\
\hline 211 & 20 & 7.75 & 10.74 & 265 & & & \\
\hline 212 & 20 & 11 & 10.88 & 260 & & & 20.5 \\
\hline 214 & 20 & 15 & 11.04 & 256 & & & \\
\hline 216 & 20 & 19 & 11.21 & & & & 20 \\
\hline 217 & 20 & 23 & 11.38 & & & & 19 \\
\hline 219 & 21 & 7.5 & 11.73 & 275 & & & \\
\hline 220 & 21 & 11 & 11.88 & 289 & & & \\
\hline 222 & 21 & 15 & 12.04 & 303 & & & \\
\hline 224 & 21 & 19 & 12.21 & 315 & & & 20 \\
\hline
\end{tabular}


Table 5.1 (continued): Results of Field Analyses for MW-156

\begin{tabular}{|c|c|c|c|c|c|c|c|}
\hline $\begin{array}{l}\text { Sample } \\
\text { Number }\end{array}$ & $\begin{array}{l}\text { Day of } \\
\text { Month }\end{array}$ & $\begin{array}{l}\text { Hour } \\
\text { of Day }\end{array}$ & $\begin{array}{c}\text { Time } \\
\text { Since } \\
\text { Extraction } \\
\text { Began } \\
\text { (days) }\end{array}$ & $\begin{array}{l}\text { Avg. } \\
\text { TCE } \\
\text { Conc. } \\
\text { Data } \\
(\mathrm{mg} / \mathrm{L})\end{array}$ & $\begin{array}{l}\text { Surfactant } \\
\text { Conc. } \\
\text { Data } \\
\text { (\% by wt) }\end{array}$ & $\begin{array}{l}\text { Surfactant } \\
\text { Conc. } \\
\text { Data } \\
\text { (\% by vol) }\end{array}$ & $\begin{array}{l}\text { Temp. } \\
\text { ('C) }\end{array}$ \\
\hline 225 & 21 & 23 & 12.38 & 275 & & & 19 \\
\hline 227 & 22 & 7.5 & 12.73 & 277 & & & \\
\hline 230 & 22 & 15 & 13.04 & 329 & & & \\
\hline 233 & 22 & 23 & 13.38 & 313 & & & 20 \\
\hline 236 & 23 & 11 & 13.88 & 293 & & & \\
\hline 238 & 23 & 15 & 14.04 & 325 & & & \\
\hline 240 & 23 & 19 & 14.21 & 299 & & & 20 \\
\hline 244 & 24 & 11 & 14.88 & 312 & & & \\
\hline 248 & 24 & 19 & 15.21 & & & & 20.5 \\
\hline 253 & 25 & 10.83 & 15.87 & 312 & & & \\
\hline
\end{tabular}


Table 5.2: Precision Estimates for MW-156 Field TCE Analyses

Sample

Number Area 1 Area 2 Area 3
Student $\mathrm{t}$

95\% Conf. Interval

Sample Sample

Area 1 Area 2 Area 3 Stand. Mean

Conc. Conc. Conc. Dev. Conc.

$(\mathrm{mg} / \mathrm{L}) \quad(\mathrm{mg} / \mathrm{L})(\mathrm{mg} / \mathrm{L}) \quad(\mathrm{mg} / \mathrm{L}) \quad(\mathrm{mg} / \mathrm{L})$

$+1-$

$(\mathrm{mg} / \mathrm{L}) \quad$ (\% of mean)

$\begin{array}{rrrrrrr}11 & 22002 & 18706 & 19028 & 413 & 311 & 321 \\ 17 & 21428 & 19156 & 19887 & 395 & 325 & 347 \\ 44 & 198.8 & 221.5 & 240 & 1.9 & 2.0 & 2.1 \\ 59 & 1271 & 1406 & 1323 & 8.6 & 9.4 & 8.9 \\ 70 & 2215 & 2315 & 2167 & 14 & 14 & 13 \\ 88 & 3142 & 3222 & 3168 & 29 & 30 & 29 \\ 107 & 4790 & 4772 & 4539 & 52 & 52 & 48 \\ 118 & 5151 & 5080 & 5215 & 63 & 62 & 64 \\ 127 & 5945 & 5778 & 5985 & 61 & 58 & 61 \\ 153 & 5066 & 5227 & 5242 & 82 & 87 & 87 \\ 180 & 14355 & 14561 & 14964 & 240 & 245 & 254 \\ 196 & 11574 & 11701 & 11729 & 207 & 210 & 211 \\ 220 & 12902 & 13428 & 12420 & 239 & 252 & 227 \\ 228 & 14563 & 15772 & 14592 & 246 & 273 & 247 \\ 236 & 13684 & 13627 & 12714 & 227 & 226 & 206 \\ 244 & 39772 & 43585 & 40651 & 297 & 334 & 306 \\ 253 & 39456 & 41907 & 42505 & 294 & 318 & 324\end{array}$

$\begin{array}{rr}56.2 & 348.2 \\ 35.9 & 355.8 \\ 0.1 & 2.0 \\ 0.4 & 9.0 \\ 0.5 & 13.8 \\ 0.7 & 29.2 \\ 2.4 & 50.4 \\ 1.2 & 63.1 \\ 1.5 & 60.1 \\ 3.1 & 85.4 \\ 6.9 & 246.0 \\ 2.0 & 209.0 \\ 12.2 & 239.3 \\ 15.2 & 255.6 \\ 12.0 & 219.7 \\ 19.5 & 312.4 \\ 15.8 & 311.9\end{array}$

$\begin{array}{rr}139.6 & 40.1 \% \\ 89.1 & 25.0 \% \\ 0.3 & 16.0 \% \\ 1.1 & 11.8 \% \\ 1.2 & 8.5 \% \\ 1.7 & 5.9 \% \\ 6.1 & 12.1 \% \\ 2.9 & 4.6 \% \\ 3.8 & 6.3 \% \\ 7.8 & 9.1 \% \\ 17.1 & 7.0 \% \\ 5.0 & 2.4 \% \\ 30.4 & 12.7 \% \\ 37.7 & 14.7 \% \\ 29.7 & 13.5 \% \\ 48.5 & 15.5 \% \\ 39.2 & 12.6 \%\end{array}$


Table 5.3: Results of PGDP Analyses for MW-156

\begin{tabular}{|c|c|c|c|c|c|c|}
\hline $\begin{array}{l}\text { Sample } \\
\text { Number }\end{array}$ & $\begin{array}{l}\text { Day of } \\
\text { Month }\end{array}$ & $\begin{array}{l}\text { Hour } \\
\text { of Day }\end{array}$ & $\begin{array}{c}\text { Time } \\
\text { Since } \\
\text { Extraction } \\
\text { Began } \\
\text { (days) }\end{array}$ & $\begin{array}{l}\text { PGDP } \\
\text { TCE } \\
\text { Conc. } \\
\text { Data } \\
(\mathrm{mg} / \mathrm{L})\end{array}$ & $\begin{array}{l}\text { PGDP } \\
\text { Tc-99 } \\
\text { Conc. } \\
\text { Data } \\
(\mathrm{pCi} / \mathrm{L})\end{array}$ & $\begin{array}{c}\text { PGDP } \\
\text { Surfactant } \\
\text { Conc. } \\
\text { Data } \\
(\%)\end{array}$ \\
\hline 1 & 3 & 11.5 & -6.10 & 370 & 120 & 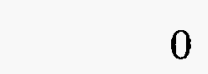 \\
\hline 6 & 3 & 14 & -6.00 & & 107 & \\
\hline 8 & 3 & 15.5 & -5.94 & 390 & & 0 \\
\hline 10 & 3 & 16.5 & -5.90 & & 106 & \\
\hline 13 & 3 & 19.5 & -5.77 & & 109 & \\
\hline 14 & 3 & 20.5 & -5.73 & 400 & & 0 \\
\hline 16 & 3 & 22.5 & -5.65 & & 104 & \\
\hline 20 & 4 & 2.5 & -5.48 & 400 & 109 & 0 \\
\hline 41 & 9 & 15 & 0.04 & 1.3 & 55 & 1.1 \\
\hline 47 & 9 & 19.58 & 0.23 & 5.5 & 79 & 0.99 \\
\hline 49 & 9 & 21 & 0.29 & & 72 & \\
\hline 53 & 10 & 1 & 0.46 & 11. & 117 & 0.92 \\
\hline 57 & 10 & 5 & 0.63 & & 39 & \\
\hline 59 & 10 & 7 & 0.71 & 15 & & 0.86 \\
\hline 62 & 10 & 9 & 0.79 & & 26 & \\
\hline 66 & 10 & 13 & 0.96 & 19 & 33 & 0.58 \\
\hline 71 & 10 & 17 & 1.13 & & 52 & \\
\hline 73 & 10 & 19 & 1.21 & 24 & & 0.53 \\
\hline 75 & 10 & 21 & 1.29 & & 32 & \\
\hline 78 & 11 & 1 & 1.46 & 30 & 33 & 0.35 \\
\hline 82 & 11 & 5 & 1.63 & & 30 & \\
\hline 84 & 11 & 7 & 1.71 & 35 & & 0.23 \\
\hline 87 & 11 & 9 & 1.79 & & 35 & \\
\hline 91 & 11 & 13 & 1.96 & 38 & 21 & 0.23 \\
\hline 96 & 11 & 17 & 2.13 & & 47 & \\
\hline 98 & 11 & 19 & 2.21 & 44 & & 0.17 \\
\hline 100 & 11 & 21 & 2.29 & & 49 & \\
\hline 112 & 12 & 8 & 2.75 & 52 & 65 & 0.09 \\
\hline 115 & 12 & 11 & 2.88 & & 53 & \\
\hline
\end{tabular}


Table 5.3 (continued): Results of PGDP Analyses for MW-156

\begin{tabular}{|c|c|c|c|c|c|c|}
\hline $\begin{array}{l}\text { Sample } \\
\text { Number }\end{array}$ & $\begin{array}{l}\text { Day of } \\
\text { Month }\end{array}$ & $\begin{array}{l}\text { Hour } \\
\text { of Day }\end{array}$ & $\begin{array}{c}\text { Time } \\
\text { Since } \\
\text { Extraction } \\
\text { Began } \\
\text { (days) }\end{array}$ & $\begin{array}{c}\text { PGDP } \\
\text { TCE } \\
\text { Conc. } \\
\text { Data } \\
(\mathrm{mg} / \mathrm{L})\end{array}$ & $\begin{array}{l}\text { PGDP } \\
\text { Tc-99 } \\
\text { Conc. } \\
\text { Data } \\
(\mathrm{pCi} / \mathrm{L})\end{array}$ & $\begin{array}{c}\text { PGDP } \\
\text { Surfactant } \\
\text { Conc. } \\
\text { Data } \\
(\%)\end{array}$ \\
\hline 118 & 12 & 14 & 3.00 & & 67 & \\
\hline 122 & 12 & 17 & 3.13 & & 54 & \\
\hline 123 & 12 & 18 & 3.17 & 59 & & 0.05 \\
\hline 138 & 13 & 8 & 3.75 & 85 & 80 & 0.04 \\
\hline 141 & 13 & 11 & 3.88 & & 84 & \\
\hline 144 & 13 & 14 & 4.00 & & 89 & \\
\hline 148 & 13 & 17 & 4.13 & 80 & 72 & 0.02 \\
\hline 158 & 14 & 8 & 4.75 & 100 & 104 & 0.018 \\
\hline 161 & 14 & 14 & 5.00 & & 86 & \\
\hline 164 & 14 & 18 & 5.17 & 110 & 97 & 0.015 \\
\hline 166 & 14 & 22 & 5.33 & & 93 & \\
\hline 167 & 15 & 7.5 & 5.73 & 130 & 92 & 0 \\
\hline 171 & 15 & 13 & 5.96 & & 95 & \\
\hline 175 & 15 & 19 & 6.21 & 120 & 101 & 0 \\
\hline 177 & 15 & 23 & 6.38 & & 115 & \\
\hline 178 & 16 & 7 & 6.71 & 150 & 94 & 0 \\
\hline 181 & 16 & 13 & 6.96 & & 93 & \\
\hline 184 & 16 & 19 & 7.21 & 150 & 105 & 0 \\
\hline 185 & 16 & 23 & 7.38 & & 88 & \\
\hline 187 & 17 & 7.5 & 7.73 & 210 & 93 & 0 \\
\hline 189 & 17 & 13 & 7.96 & & 100 & \\
\hline 192 & 17 & 19 & 8.21 & 170 & 113 & 0 \\
\hline 193 & 17 & 23 & 8.38 & & 103 & \\
\hline 195 & 18 & 7.5 & 8.73 & 200 & 90 & 0 \\
\hline 197 & 18 & 13 & 8.96 & & 107 & \\
\hline 200 & 18 & 19 & 9.21 & 210 & 106 & 0 \\
\hline 201 & 18 & 23 & 9.38 & & 112 & \\
\hline 203 & 19 & 7.5 & 9.73 & 210 & 107 & 0 \\
\hline 205 & 19 & 13 & 9.96 & & 112 & \\
\hline
\end{tabular}


Table 5.3 (continued): Results of PGDP Analyses for MW-156

\begin{tabular}{|c|c|c|c|c|c|c|}
\hline $\begin{array}{l}\text { Sample } \\
\text { Number }\end{array}$ & $\begin{array}{l}\text { Day of } \\
\text { Month }\end{array}$ & $\begin{array}{l}\text { Hour } \\
\text { of Day }\end{array}$ & $\begin{array}{c}\text { Time } \\
\text { Since } \\
\text { Extraction } \\
\text { Began } \\
\text { (days) }\end{array}$ & $\begin{array}{c}\text { PGDP } \\
\text { TCE } \\
\text { Conc. } \\
\text { Data } \\
(\mathrm{mg} / \mathrm{L})\end{array}$ & $\begin{array}{l}\text { PGDP } \\
\text { Tc-99 } \\
\text { Conc. } \\
\text { Data } \\
(\mathrm{pCi} / \mathrm{L})\end{array}$ & $\begin{array}{c}\text { PGDP } \\
\text { Surfactant } \\
\text { Conc. } \\
\text { Data } \\
(\%)\end{array}$ \\
\hline 208 & 19 & 19 & 10.21 & 210 & 100 & 0 \\
\hline 209 & 19 & 23 & 10.38 & & 94 & \\
\hline 211 & 20 & 7.75 & 10.74 & 190 & 117 & 0 \\
\hline 213 & 20 & 13 & 10.96 & & 108 & \\
\hline 216 & 20 & 19 & 11.21 & 200 & 95 & 0 \\
\hline 217 & 20 & 23 & 11.38 & & 115 & \\
\hline 219 & 21 & 7.5 & 11.73 & 200 & 98 & 0 \\
\hline 221 & 21 & 13 & 11.96 & & 111 & \\
\hline 224 & 21 & 19 & 12.21 & 230 & 102 & 0 \\
\hline 225 & 21 & 23 & 12.38 & & 100 & \\
\hline 227 & 22 & 7.5 & 12.73 & 220 & 107 & 0 \\
\hline 232 & 22 & 19 & 13.21 & 210 & 105 & 0 \\
\hline 233 & 22 & 23 & 13.38 & & 98 & \\
\hline 235 & 23 & 7.33 & 13.72 & 220 & 97 & 0 \\
\hline 237 & 23 & 13 & 13.96 & & 104 & \\
\hline 240 & 23 & 19 & 14.21 & 240 & 111 & 0 \\
\hline 242 & 23 & 23 & 14.38 & & 96 & \\
\hline 243 & 24 & 7.5 & 14.73 & 230 & 95 & 0 \\
\hline 245 & 24 & 13 & 14.96 & & 105 & \\
\hline 248 & 24 & 19 & 15.21 & 220 & 113 & 0 \\
\hline 249 & 24 & 23 & 15.38 & & 109 & \\
\hline 251 & 25 & 7.42 & 15.73 & 210 & 121 & 0 \\
\hline 253 & 25 & 10.83 & 15.87 & 220 & 105 & 0 \\
\hline
\end{tabular}


Table 5.4: Matched-Pairs Analysis of Differences in Field and PGDP Results for MW-156

\begin{tabular}{|c|c|c|c|c|c|}
\hline $\begin{array}{l}\text { Sample } \\
\text { Number }\end{array}$ & $\begin{array}{c}\text { PGDP } \\
\text { TCE } \\
\text { Conc. } \\
\text { Data } \\
(\mathrm{ppm})\end{array}$ & $\begin{array}{c}\text { Field } \\
\text { TCE } \\
\text { Conc. } \\
\text { Data } \\
(\mathrm{mg} / \mathrm{L})\end{array}$ & $\begin{array}{l}\text { Difference } \\
(\mathrm{mg} / \mathrm{L})\end{array}$ & & \\
\hline 1 & 370 & 353 & 17 & & \\
\hline 8 & 390 & 308 & 82 & & \\
\hline 14 & 400 & 300 & 100 & & \\
\hline 20 & 400 & 359 & 41 & & \\
\hline 41 & 1.3 & 1 & 0 & & \\
\hline 53 & 11 & 7 & 4 & & \\
\hline 59 & 15 & 9 & 6 & & . \\
\hline 66 & 19 & 11 & 8 & Student $\mathrm{t}$ & \\
\hline 73 & 24 & 15 & 9 & & \\
\hline 78 & 30 & 20 & 10 & & \\
\hline 84 & 35 & 29 & 6 & Sample Mean Difference & -22 \\
\hline 91 & 38 & 31 & 7 & Sample Standard Deviation & 53 \\
\hline 98 & 44 & 44 & 0 & & \\
\hline 112 & 52 & 55 & -3 & Number of Matched Pairs & 29 \\
\hline 138 & 85 & 75 & 10 & Degrees of Freedom & 28 \\
\hline 158 & 100 & 104 & -4 & & \\
\hline 164 & 110 & 158 & -48 & Critical Value of Test Statistic & \\
\hline 167 & 130 & 207 & -77 & $5 \%$ significance level & -1.70 \\
\hline 178 & 150 & 230 & -80 & & \\
\hline 184 & 150 & 250 & -100 & Actual Value of Test Statistic & -2.19 \\
\hline 187 & 210 & 250 & -40 & & \\
\hline 192 & 170 & 281 & -111 & & \\
\hline 195 & 200 & 218 & -18 & \multirow{2}{*}{ Conclusion } & \\
\hline 211 & 190 & 265 & -75 & & \\
\hline 219 & 200 & 275 & -75 & \multirow{3}{*}{\multicolumn{2}{|c|}{$\begin{array}{l}\text { The PGDP TCE measurements are significantly } \\
\text { lower than the field measurements. }\end{array}$}} \\
\hline 224 & 230 & 315 & -85 & & \\
\hline 227 & 220 & 277 & -57 & & \\
\hline 240 & 240 & 299 & -59 & \multirow{2}{*}{\multicolumn{2}{|c|}{$\begin{array}{l}\text { There is a probability of less than } 5 \% \\
\text { that this conclusion is incorrect. }\end{array}$}} \\
\hline 253 & 220 & 312 & -92 & & \\
\hline
\end{tabular}


Table 5.5: Results of Field Analyses for MW-155

\begin{tabular}{|c|c|c|c|c|c|c|}
\hline $\begin{array}{l}\text { Sample } \\
\text { Number }\end{array}$ & $\begin{array}{l}\text { Day of } \\
\text { Month }\end{array}$ & $\begin{array}{l}\text { Hour } \\
\text { of Day }\end{array}$ & $\begin{array}{c}\text { Time } \\
\text { Since } \\
\text { Extraction } \\
\text { Began } \\
\text { (days) }\end{array}$ & $\begin{array}{c}\text { Average } \\
\text { TCE } \\
\text { Concentration } \\
\text { Measurement } \\
(\mathrm{mg} / \mathrm{L})\end{array}$ & $\begin{array}{c}\text { Surfactant } \\
\text { Concentration } \\
\text { Measurement } \\
\text { (\% by wt) }\end{array}$ & $\begin{array}{c}\text { Surfactant } \\
\text { Concentration } \\
\text { Measurement } \\
\text { (\% by vol) }\end{array}$ \\
\hline 2 & 3 & 11.5 & -6.10 & 1.4 & $<0.01$ & $<0.01$ \\
\hline 9 & 3 & 15.5 & -5.94 & $<1$ & $<0.01$ & $<0.01$ \\
\hline 26 & 6 & 7.0 & -3.29 & $<1$ & $<0.01$ & $<0.01$ \\
\hline 28 & 6 & 15.5 & -2.94 & 1.4 & $<0.01$ & $<0.01$ \\
\hline 29 & 7 & 6.9 & -2.30 & 1.4 & $<0.01$ & $<0.01$ \\
\hline 33 & 7 & 15.8 & -1.92 & 1.5 & $<0.01$ & $<0.01$ \\
\hline 34 & 8 & 7.0 & -1.29 & 1.4 & $<0.01$ & $<0.01$ \\
\hline 36 & 8 & 16.0 & -0.92 & 1.1 & $<0.01$ & $<0.01$ \\
\hline 38 & 9 & 7.0 & -0.29 & 1.3 & $<0.01$ & $<0.01$ \\
\hline 42 & 9 & 15.5 & 0.06 & 1.2 & $<0.01$ & $<0.01$ \\
\hline 60 & 10 & 7.0 & 0.71 & 1.4 & $<0.01$ & $<0.01$ \\
\hline 69 & 10 & 16.0 & 1.08 & 1.4 & $<0.01$ & $<0.01$ \\
\hline 85 & 11 & 7.0 & 1.71 & 1.2 & $<0.01$ & $<0.01$ \\
\hline 94 & 11 & 16.0 & 2.08 & 1.3 & $<0.01$ & $<0.01$ \\
\hline 111 & 12 & 7.0 & 2.71 & 1.4 & & \\
\hline 121 & 12 & 16.0 & 3.08 & 1.2 & & \\
\hline 137 & 13 & 7.0 & 3.71 & 1.3 & & \\
\hline 146 & 13 & 16.0 & 4.08 & 1.5 & & \\
\hline 157 & 14 & 7.0 & 4.71 & 1.4 & & \\
\hline 162 & 14 & 16.0 & 5.08 & 1.5 & & \\
\hline 168 & 15 & 7.0 & 5.71 & 1.4 & & \\
\hline 173 & 15 & 16.0 & 6.08 & 1.4 & & \\
\hline 179 & 16 & 7.0 & 6.71 & 1.5 & & \\
\hline 183 & 16 & 16.0 & 7.08 & 1.5 & & \\
\hline 186 & 17 & 7.0 & 7.71 & 1.5 & & \\
\hline 191 & 17 & 16.0 & 8.08 & 1.3 & & \\
\hline 194 & 18 & 7.0 & 8.71 & 1.7 & & \\
\hline 199 & 18 & 16.0 & 9.08 & 1.6 & & \\
\hline 202 & 19 & 7.0 & 9.71 & 1.7 & & \\
\hline
\end{tabular}


Table 5.5 (continued): Results of Field Analyses for MW-155

\begin{tabular}{|c|c|c|c|c|c|c|}
\hline $\begin{array}{l}\text { Sample } \\
\text { Number }\end{array}$ & $\begin{array}{l}\text { Day of } \\
\text { Month }\end{array}$ & $\begin{array}{l}\text { Hour } \\
\text { of Day }\end{array}$ & $\begin{array}{l}\text { Time } \\
\text { Since } \\
\text { Extraction } \\
\text { Began } \\
\text { (days) }\end{array}$ & $\begin{array}{c}\text { Average } \\
\text { TCE } \\
\text { Concentration } \\
\text { Measurement } \\
\text { (mg/L) }\end{array}$ & $\begin{array}{c}\text { Surfactant } \\
\text { Concentration } \\
\text { Measurement } \\
\text { (\% by wt) }\end{array}$ & $\begin{array}{c}\text { Surfactant } \\
\text { Concentration } \\
\text { Measurement } \\
\text { (\% by vol) }\end{array}$ \\
\hline 207 & 19 & 16.0 & 10.08 & 1.5 & & \\
\hline 210 & 20 & 7.0 & 10.71 & 1.6 & & \\
\hline 215 & 20 & 16.0 & 11.08 & 1.6 & & \\
\hline 218 & 21 & 7.0 & 11.71 & 1.7 & & \\
\hline 223 & 21 & 16.0 & 12.08 & 1.5 & & \\
\hline 226 & 22 & 7.0 & 12.71 & 1.8 & & \\
\hline 231 & 22 & 16.0 & 13.08 & 1.6 & & \\
\hline 234 & 23 & 7.0 & 13.71 & 1.6 & & \\
\hline 239 & 23 & 16.0 & 14.08 & 1.7 & & \\
\hline 241 & 24 & 7.0 & 14.71 & 1.8 & & \\
\hline 247 & 24 & 16.0 & 15.08 & 1.6 & & \\
\hline 250 & 25 & 7.0 & 15.71 & 1.7 & & \\
\hline 252 & 25 & 11.0 & 15.88 & 2.2 & & \\
\hline
\end{tabular}


Table 5.6: Results of PGDP Analyses for MW-155

Time

Since

Extraction Dissolved

Sample Day of Hour

Oxygen

Temp. Temp.

TCE

Numbe Month of Day

$$
\text { (days) }
$$

$(\mathrm{mg} / \mathrm{L})$

('F)

('C)

$\mathrm{pH} \quad(\mathrm{ppm})$

$\begin{array}{rrrrrrrrr}2 & 3 & 11.5 & -6.10 & 3.78 & 67 & 19.4 & 5.7 & 2.0 \\ 9 & 3 & 15.5 & -5.94 & & 77 & 25.0 & 6.4 & \\ 26 & 6 & 7.0 & -3.29 & 5.3 & 65 & 18.3 & 5.2 & \\ 28 & 6 & 15.5 & -2.94 & 3.94 & 67 & 19.4 & 5.3 & \\ 29 & 7 & 6.9 & -2.30 & 4 & 65 & 18.3 & 6.1 & \\ 33 & 7 & 15.8 & -1.92 & 3.94 & 68 & 20.0 & 5.8 & \\ 34 & 8 & 7.0 & -1.29 & 4.54 & 65 & 18.3 & 6.1 & \\ 36 & 8 & 16.0 & -0.92 & 3.74 & 67 & 19.4 & 5.8 & \\ 38 & 9 & 7.0 & -0.29 & 5.56 & 65 & 18.3 & 5.9 & \\ 42 & 9 & 15.5 & 0.06 & 5.62 & 68 & 20.0 & 6 & 1.6 \\ 60 & 10 & 7.0 & 0.71 & 5.11 & 66 & 18.9 & 5.9 & \\ 69 & 10 & 16.0 & 1.08 & 5.45 & 73 & 22.8 & 6.2 & \\ 85 & 11 & 7.0 & 1.71 & 6.06 & 72 & 22.2 & 5.9 & \\ 94 & 11 & 16.0 & 2.08 & 5.22 & 72 & 22.2 & 6.2 & \\ 111 & 12 & 7.0 & 2.71 & 2.45 & 66 & 18.9 & 5.9 & \\ 121 & 12 & 16.0 & 3.08 & 3.87 & 68 & 20.0 & 6 & \\ 137 & 13 & 7.0 & 3.71 & 3.5 & 66 & 18.9 & 6 & \\ 146 & 13 & 16.0 & 4.08 & 3.72 & 68 & 20.0 & 6.1 & \\ 157 & 14 & 7.0 & 4.71 & 3.88 & 66 & 18.9 & 6.1 & \\ 162 & 14 & 16.0 & 5.08 & 4.06 & 66 & 18.9 & 6 & \\ 168 & 15 & 7.0 & 5.71 & 4.65 & 66 & 18.9 & 6.1 & 1.5 \\ 173 & 15 & 16.0 & 6.08 & 6.03 & 72 & 22.2 & 6.1 & \\ 179 & 16 & 7.0 & 6.71 & 6.48 & 65 & 18.3 & 5.7 & \\ 183 & 16 & 16.0 & 7.08 & 5.08 & 68 & 20.0 & 5.9 & \\ 186 & 17 & 7.0 & 7.71 & 5.84 & 67 & 19.4 & 5.7 & \\ 191 & 17 & 16.0 & 8.08 & 4.99 & 70 & 21.1 & 6 & \\ 194 & 18 & 7.0 & 8.71 & 6.62 & 67 & 19.4 & 5.8 & \\ 199 & 18 & 16.0 & 9.08 & 4.88 & 69 & 20.6 & 6.1 & \\ 202 & 19 & 7.0 & 9.71 & 6.27 & 67 & 19.4 & 6.2 & 1.5\end{array}$


Table 5.6 (continued): Results of PGDP Analyses for MW-155

\begin{tabular}{|c|c|c|c|c|c|c|c|c|}
\hline $\begin{array}{l}\text { Sample } \\
\text { Numbe }\end{array}$ & $\begin{array}{l}\text { Day of } \\
\text { Month }\end{array}$ & $\begin{array}{l}\text { Hour } \\
\text { of Day }\end{array}$ & $\begin{array}{c}\text { Time } \\
\text { Since } \\
\text { Extraction } \\
\text { Began } \\
\text { (days) }\end{array}$ & $\begin{array}{c}\text { Dissolved } \\
\text { Oxygen } \\
(\mathrm{mg} / \mathrm{L})\end{array}$ & $\begin{array}{l}\text { Temp. } \\
\text { ('F) }\end{array}$ & $\begin{array}{l}\text { Temp. } \\
\text { ('C) }\end{array}$ & $\mathrm{pH}$ & $\begin{array}{c}\text { TCE } \\
(\mathrm{ppm})\end{array}$ \\
\hline 207 & 19 & 16.0 & 10.08 & 6.12 & 72 & 22.2 & 6.5 & \\
\hline 210 & 20 & 7.0 & 10.71 & 6.73 & 69 & 20.6 & 6.4 & \\
\hline 215 & 20 & 16.0 & 11.08 & 6.33 & 69 & 20.6 & 6.3 & \\
\hline 218 & 21 & 7.0 & 11.71 & 5.78 & 65 & 18.3 & 6.3 & \\
\hline 223 & 21 & 16.0 & 12.08 & 6.13 & 70 & 21.1 & 6.4 & \\
\hline 226 & 22 & 7.0 & 12.71 & 6.37 & 66 & 18.9 & 6.5 & \\
\hline 231 & 22 & $16: 0$ & 13.08 & 4.82 & 67 & 19.4 & 6.5 & \\
\hline 234 & 23 & 7.0 & 13.71 & 5.61 & 66 & 18.9 & 6.5 & \\
\hline 239 & 23 & 16.0 & 14.08 & & & & & \\
\hline 241 & 24 & 7.0 & 14.71 & 6.12 & 67 & 19.4 & 6.5 & \\
\hline 247 & 24 & 16.0 & 15.08 & 5.26 & 71 & 21.7 & 6.6 & \\
\hline 250 & 25 & 7.0 & 15.71 & 6.2 & 71 & 21.7 & 6.5 & 1.6 \\
\hline 252 & 25 & 11.0 & 15.88 & 4.97 & 76 & 24.4 & 6.5 & 1.6 \\
\hline
\end{tabular}


Table 5.7: Matched-Pairs Analysis of Differences in Field and PGDP Results for MW-155

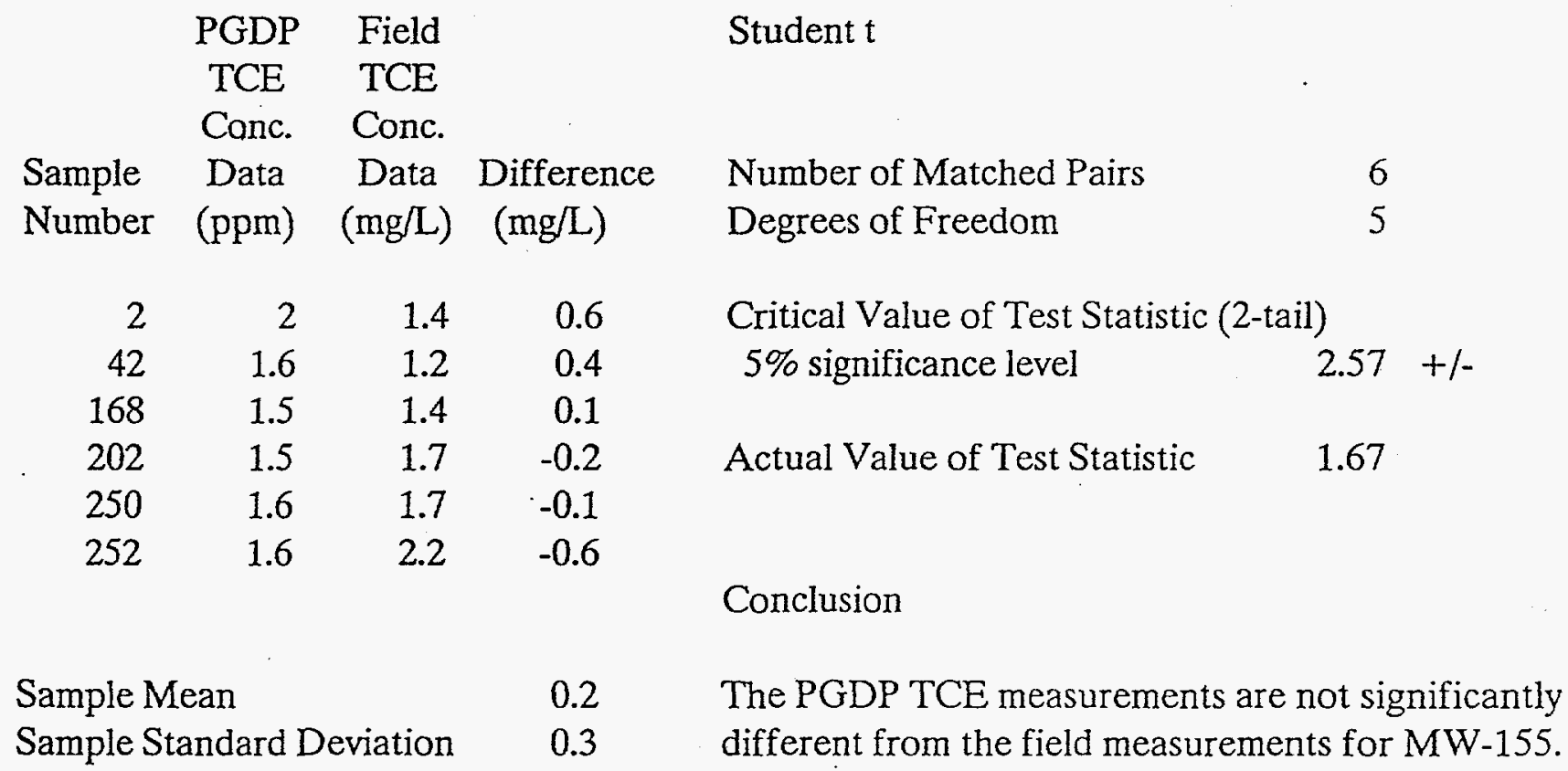


FIGURES

$112504-2$ 


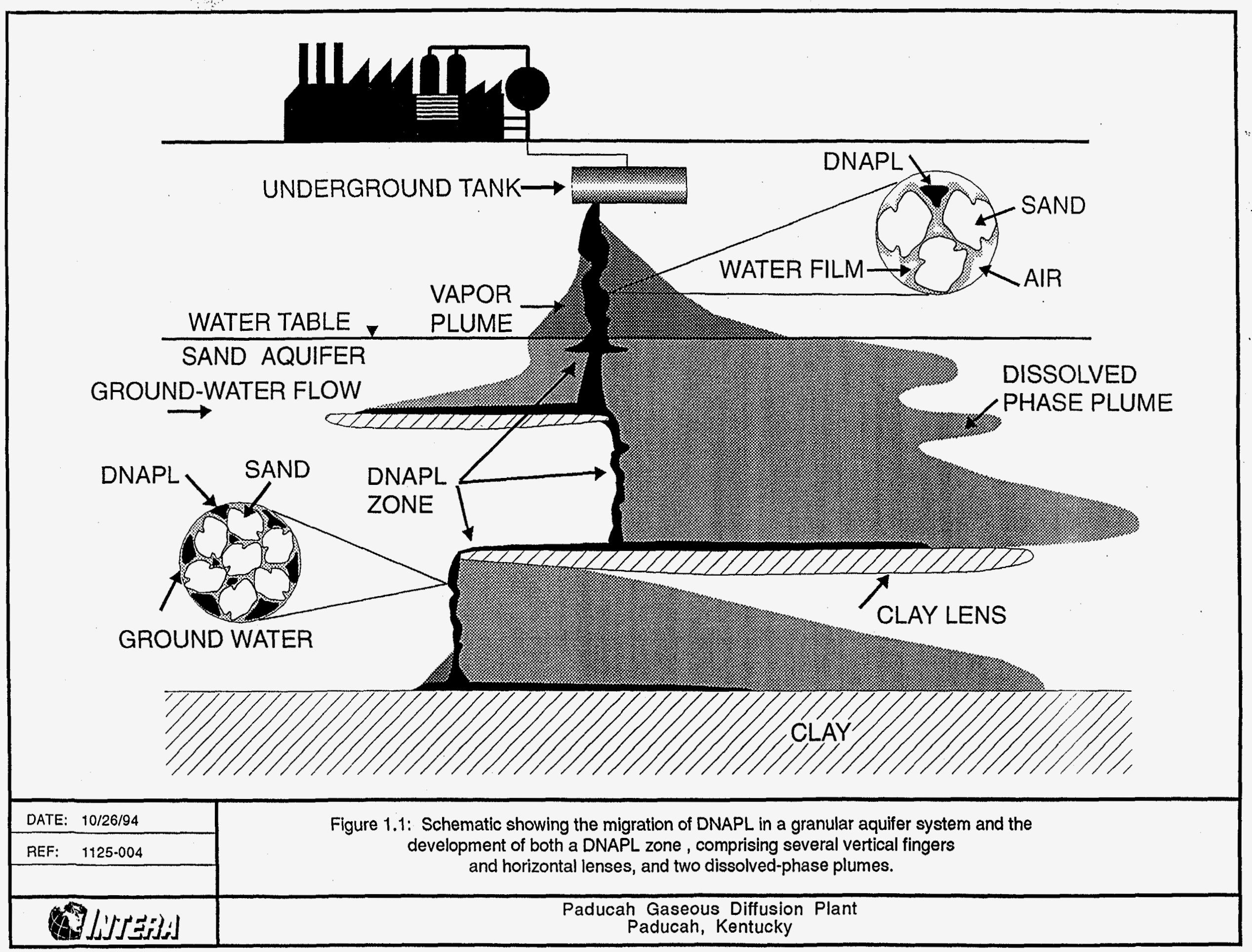




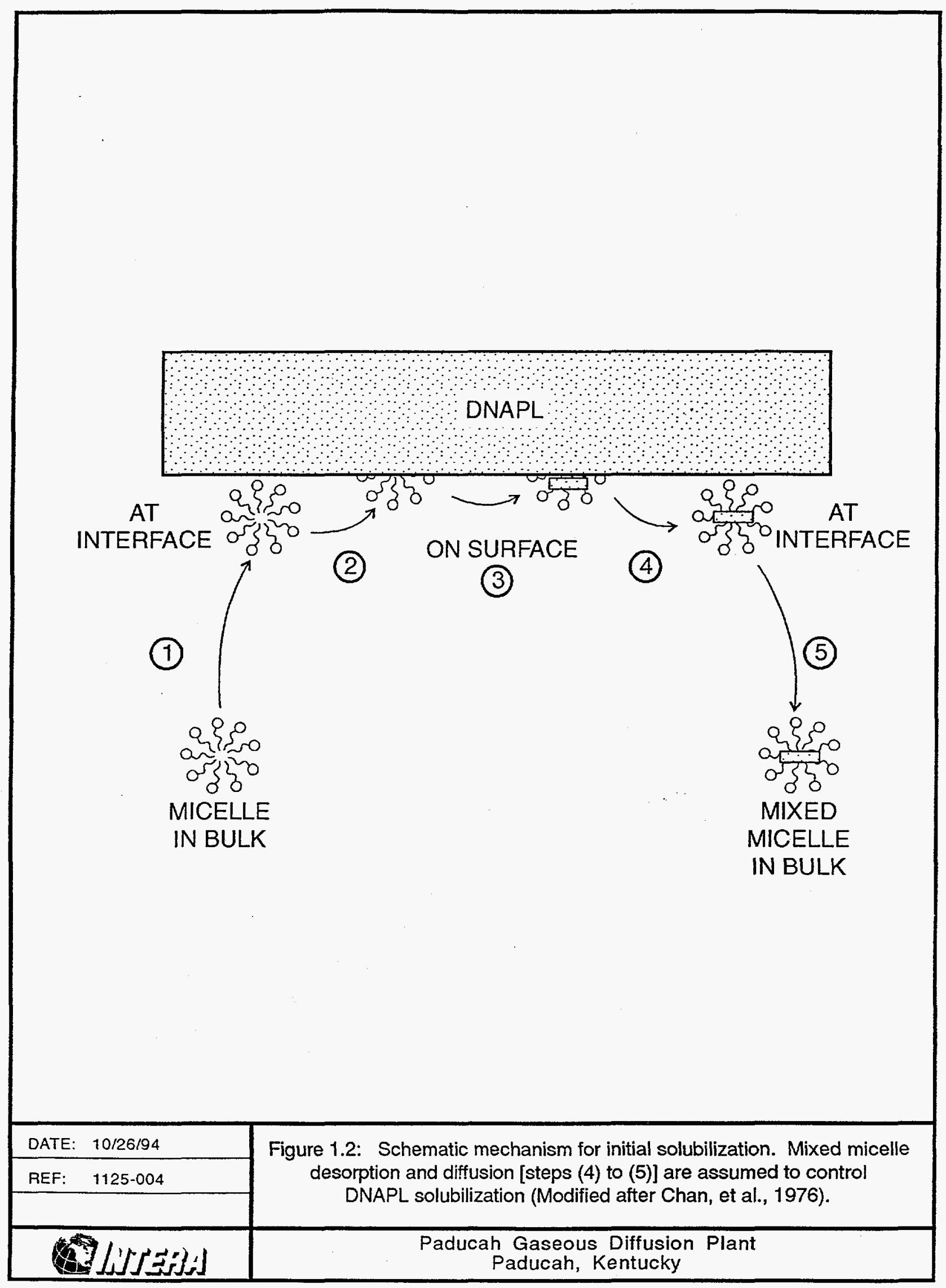




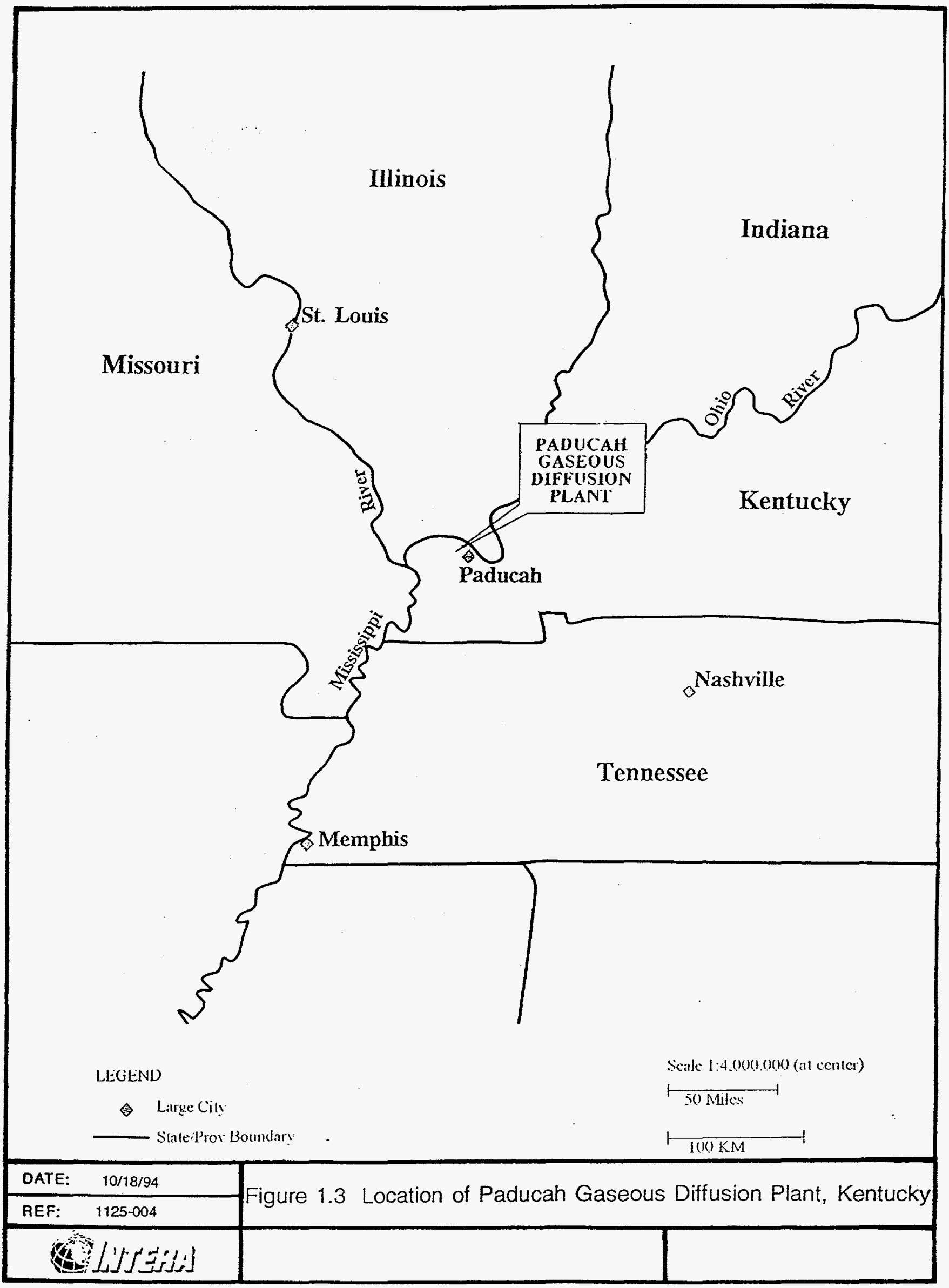




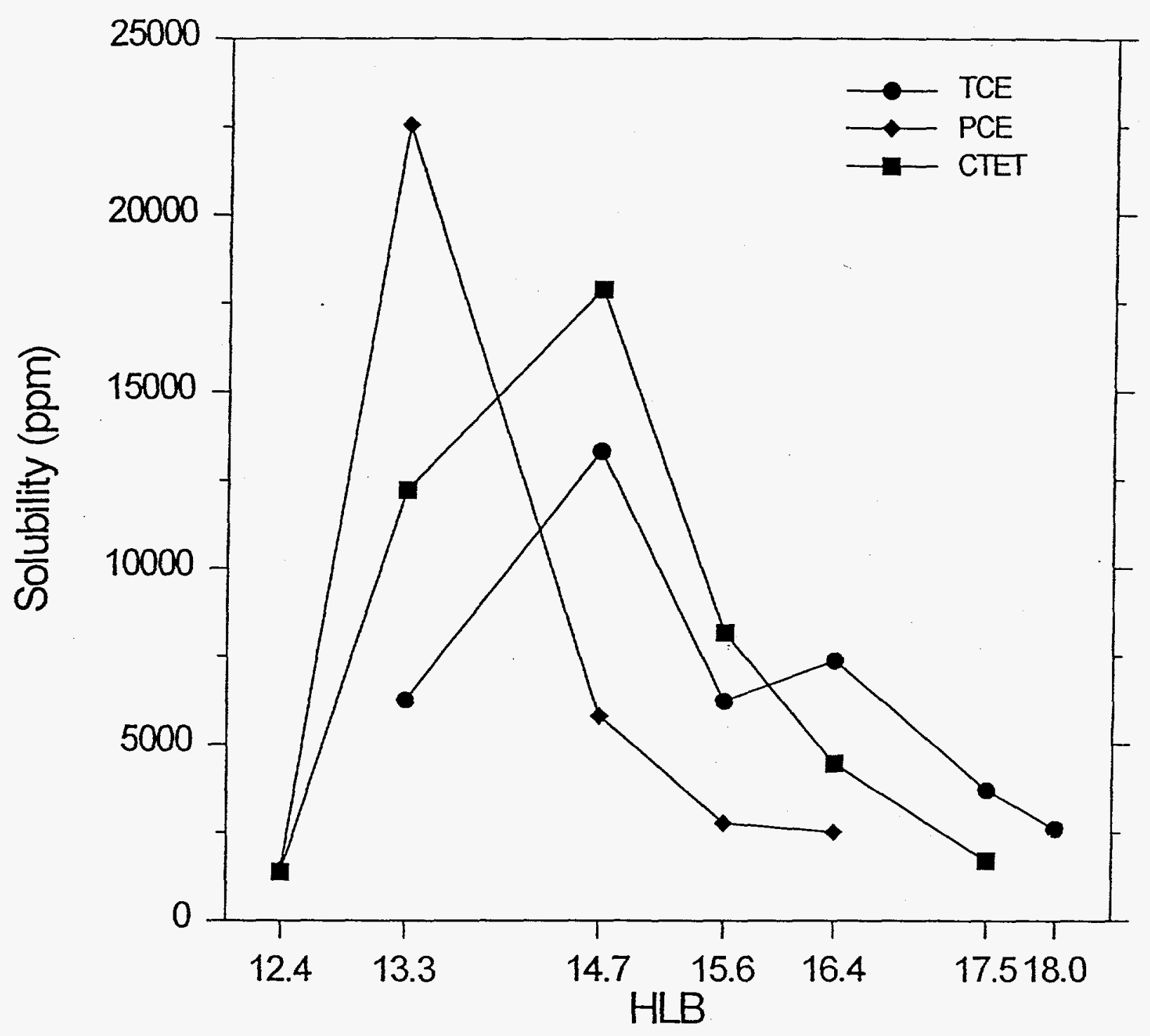




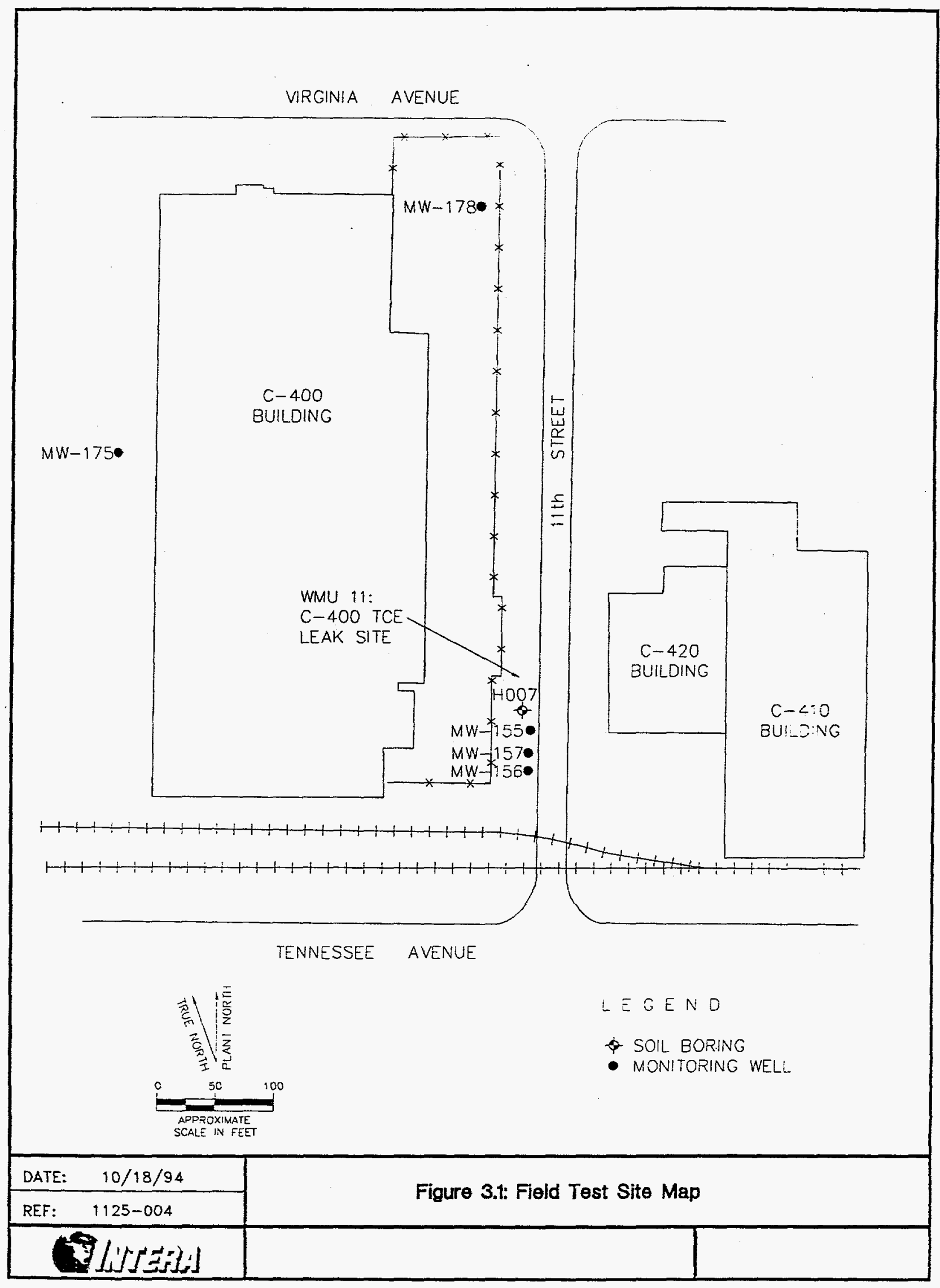




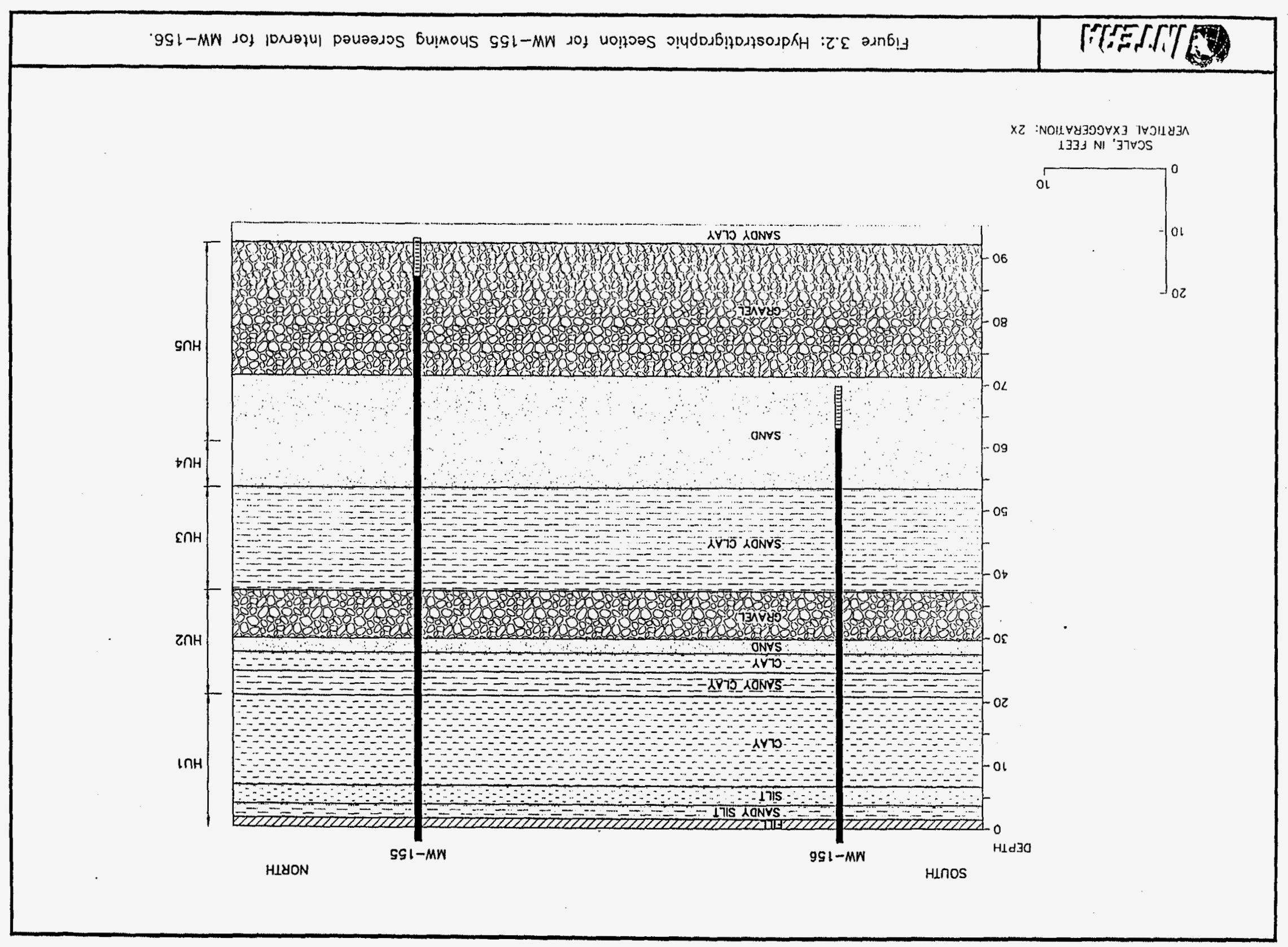




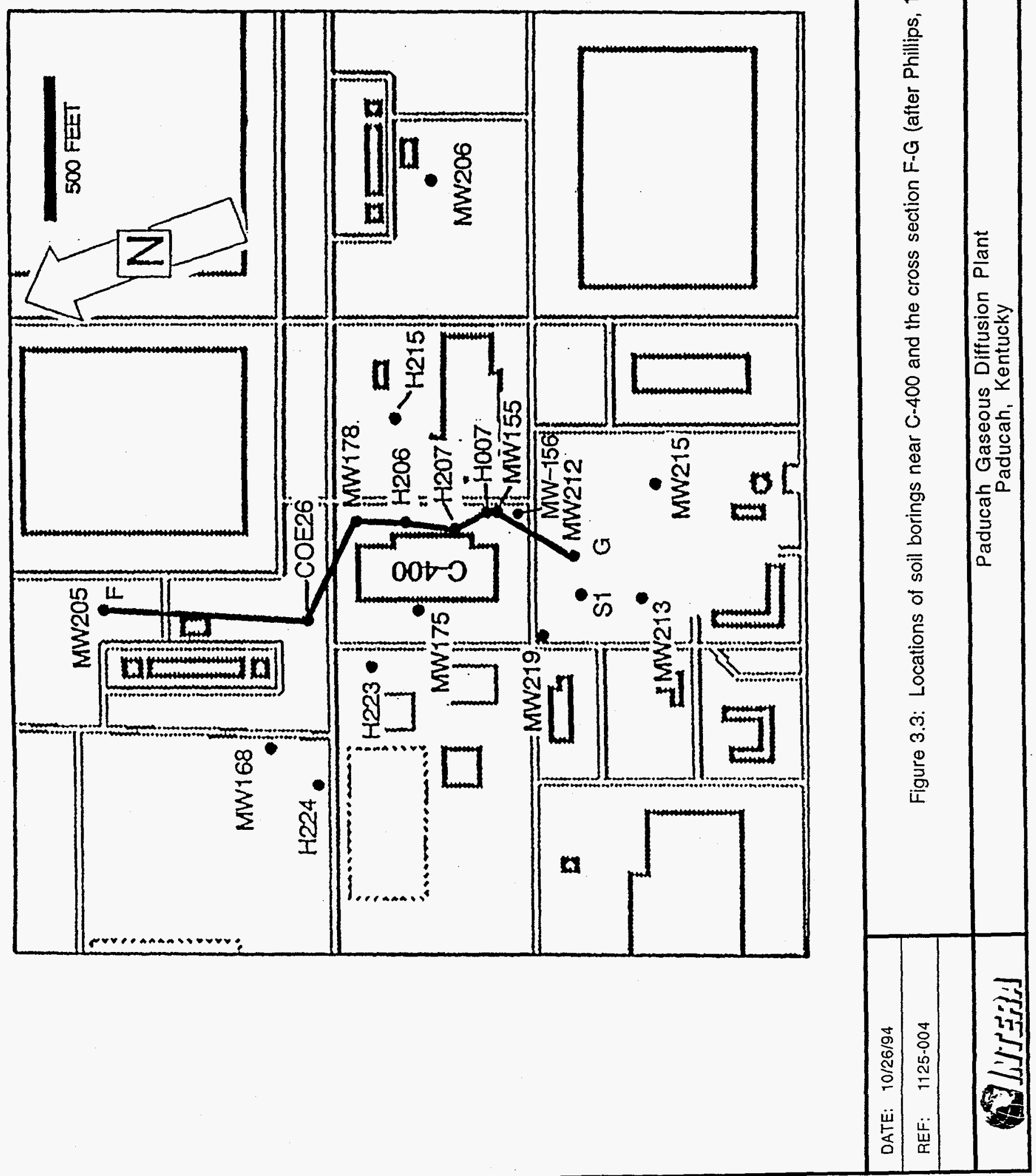




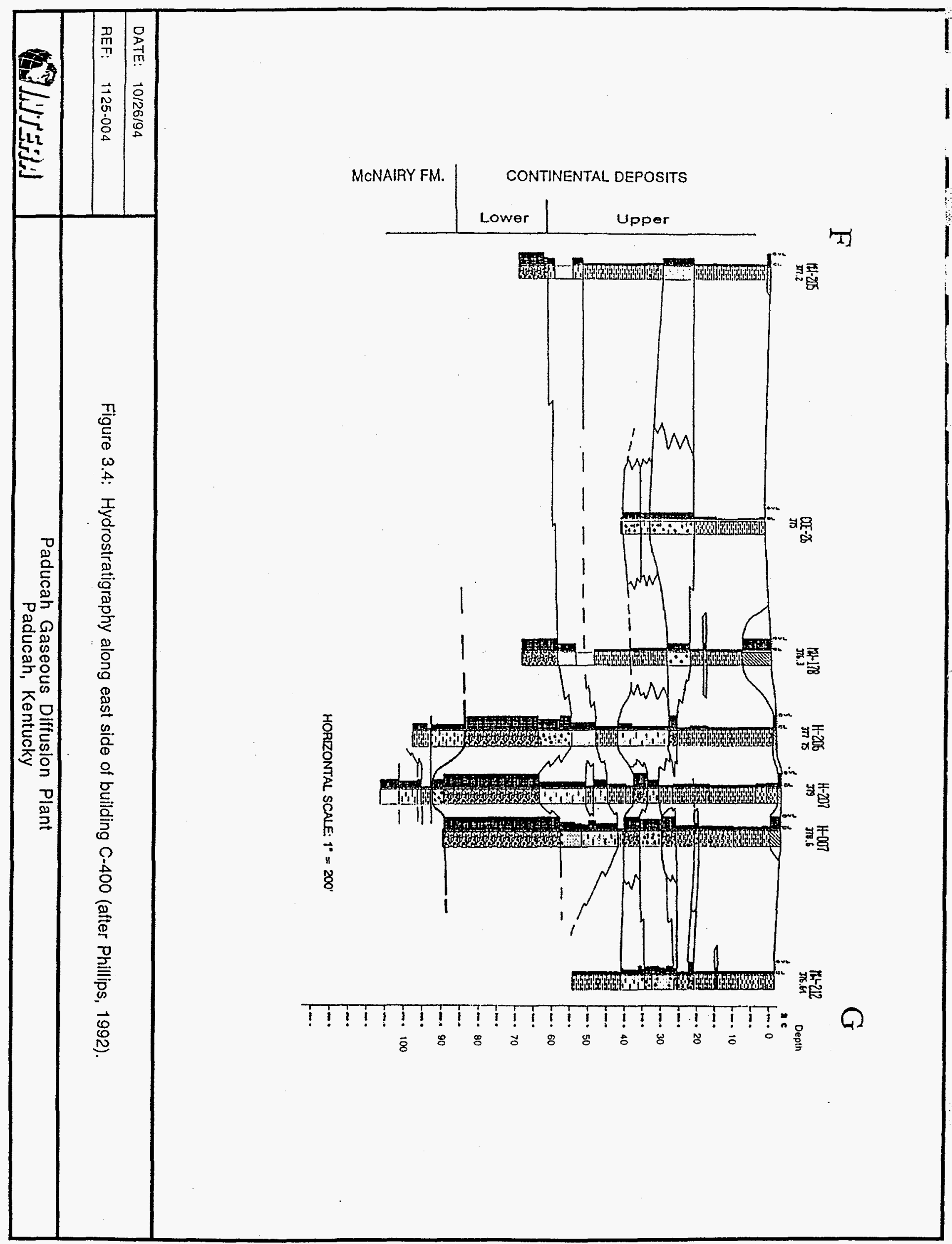




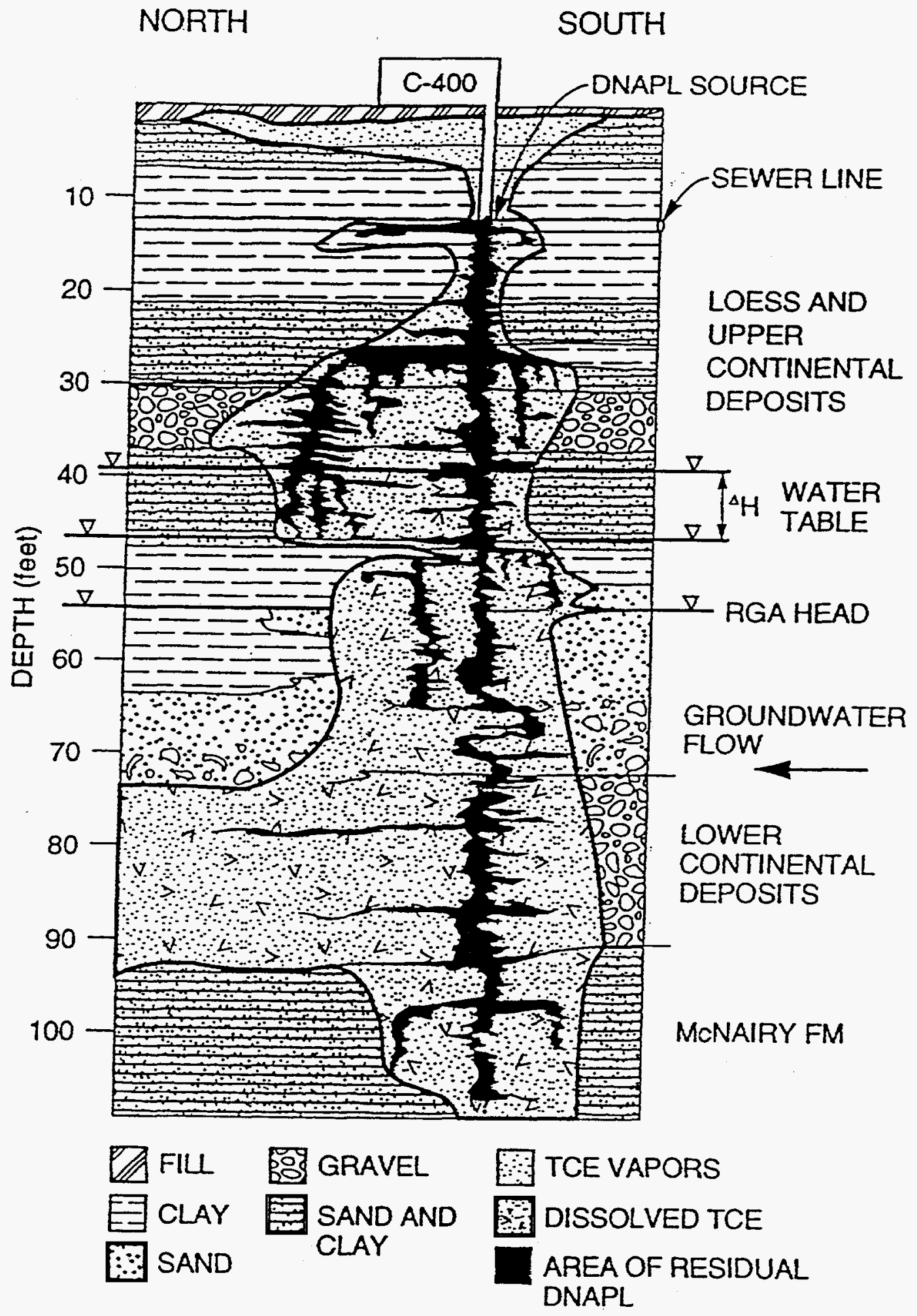

\begin{tabular}{|l|c|}
\hline DATE: $10 / 26 / 94$ & Figure 3.5: Conceptual model of DNAPL distribution in the subsurface beneath the \\
C-400 building at PGDP (from Clausen et at., 1992).
\end{tabular}




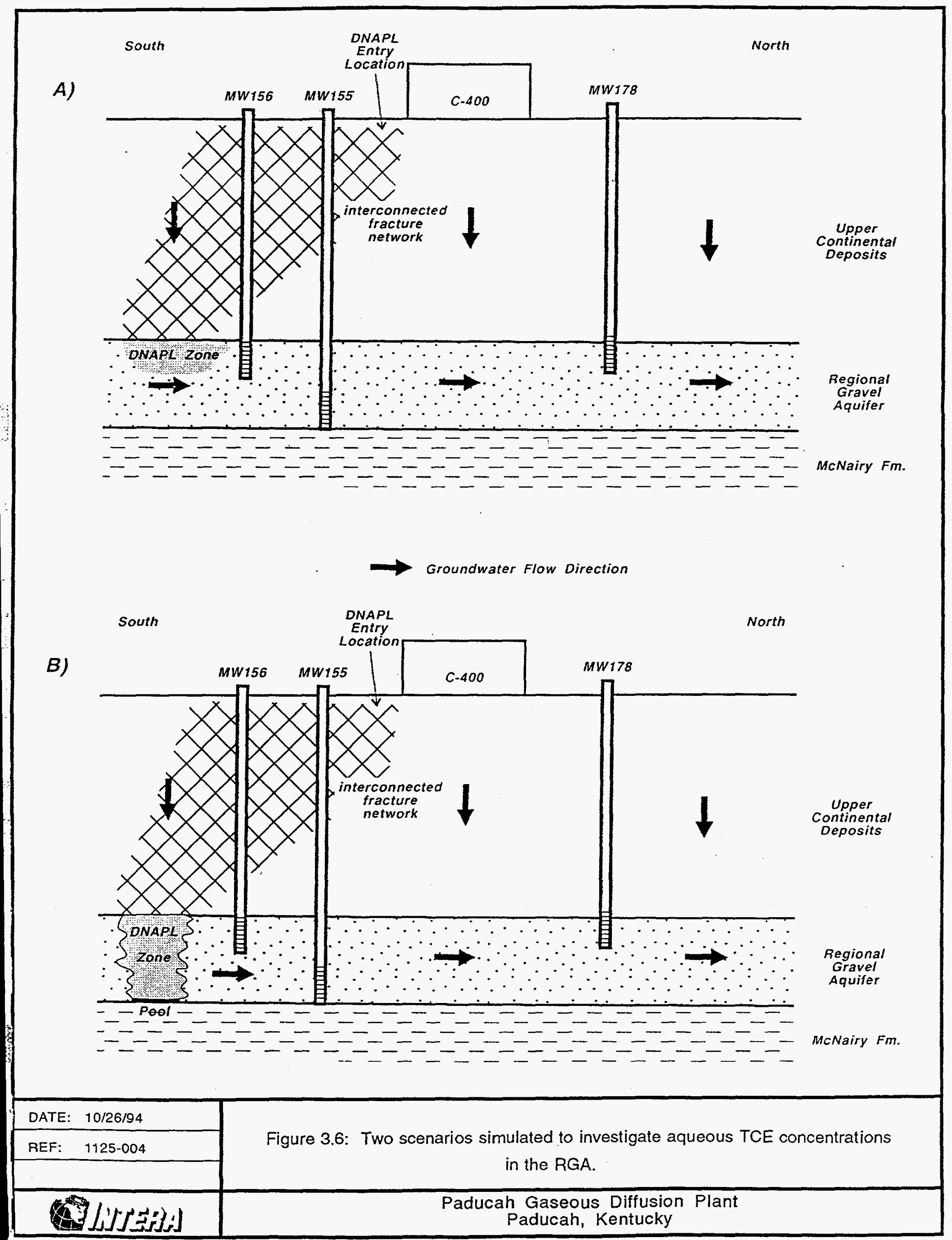




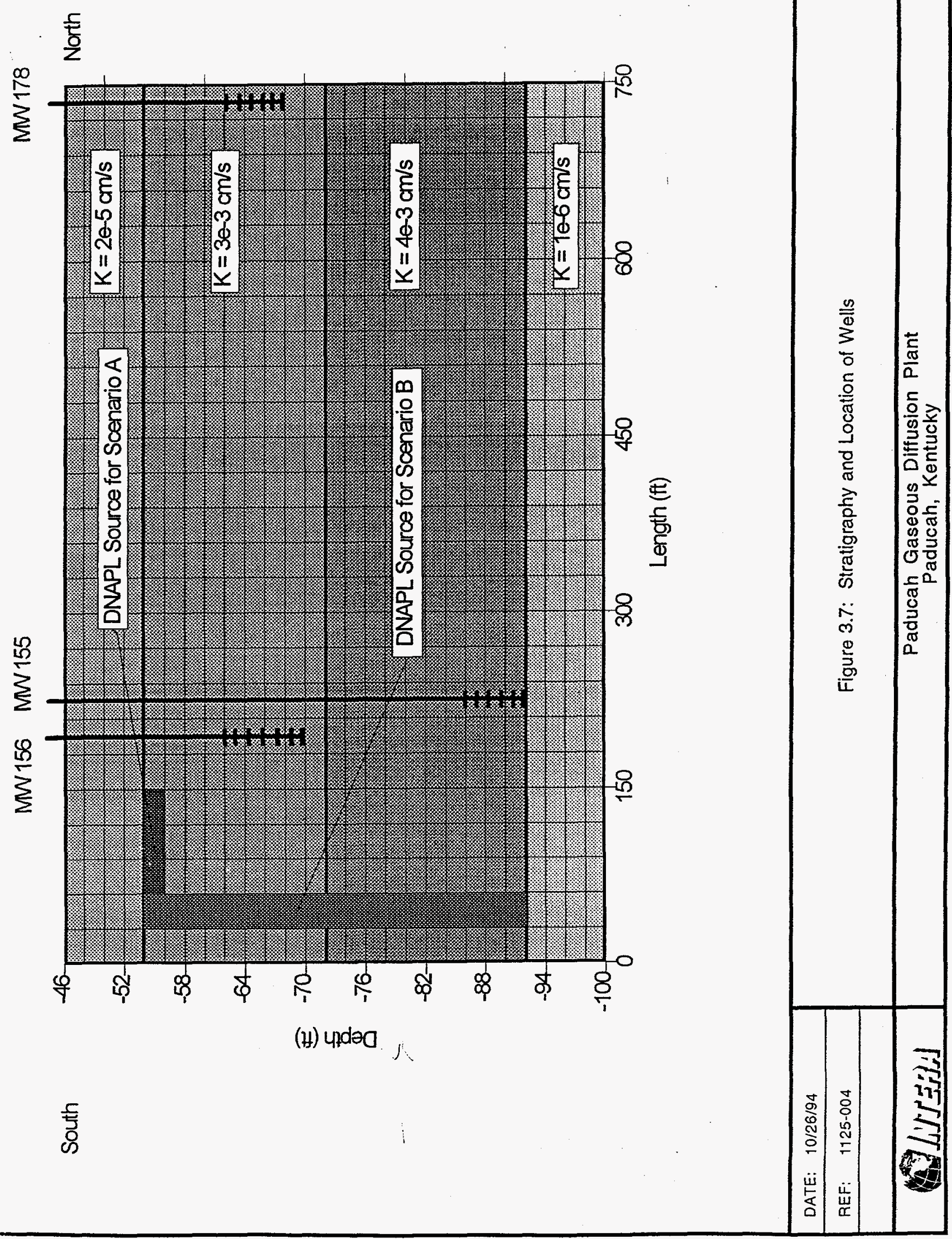




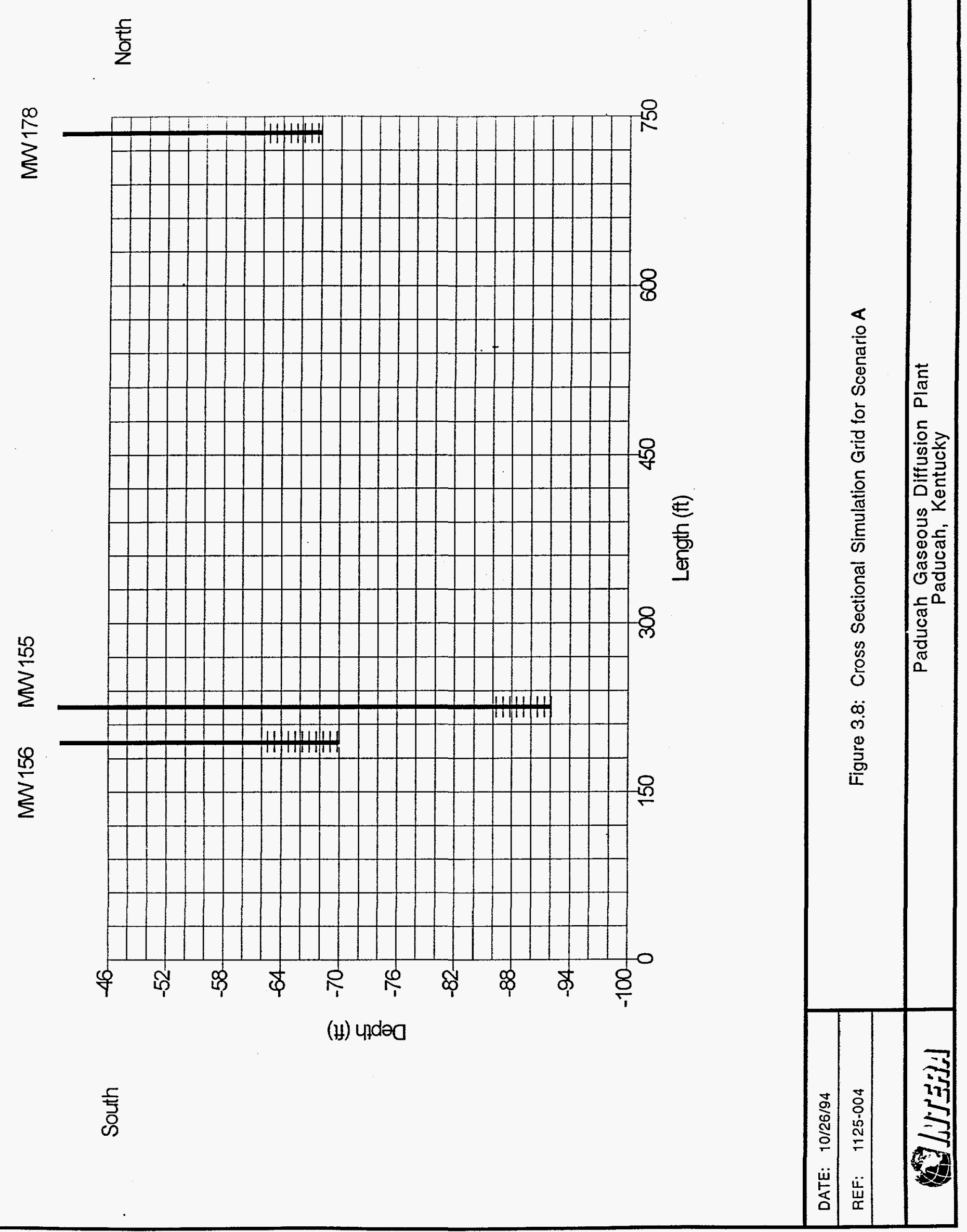




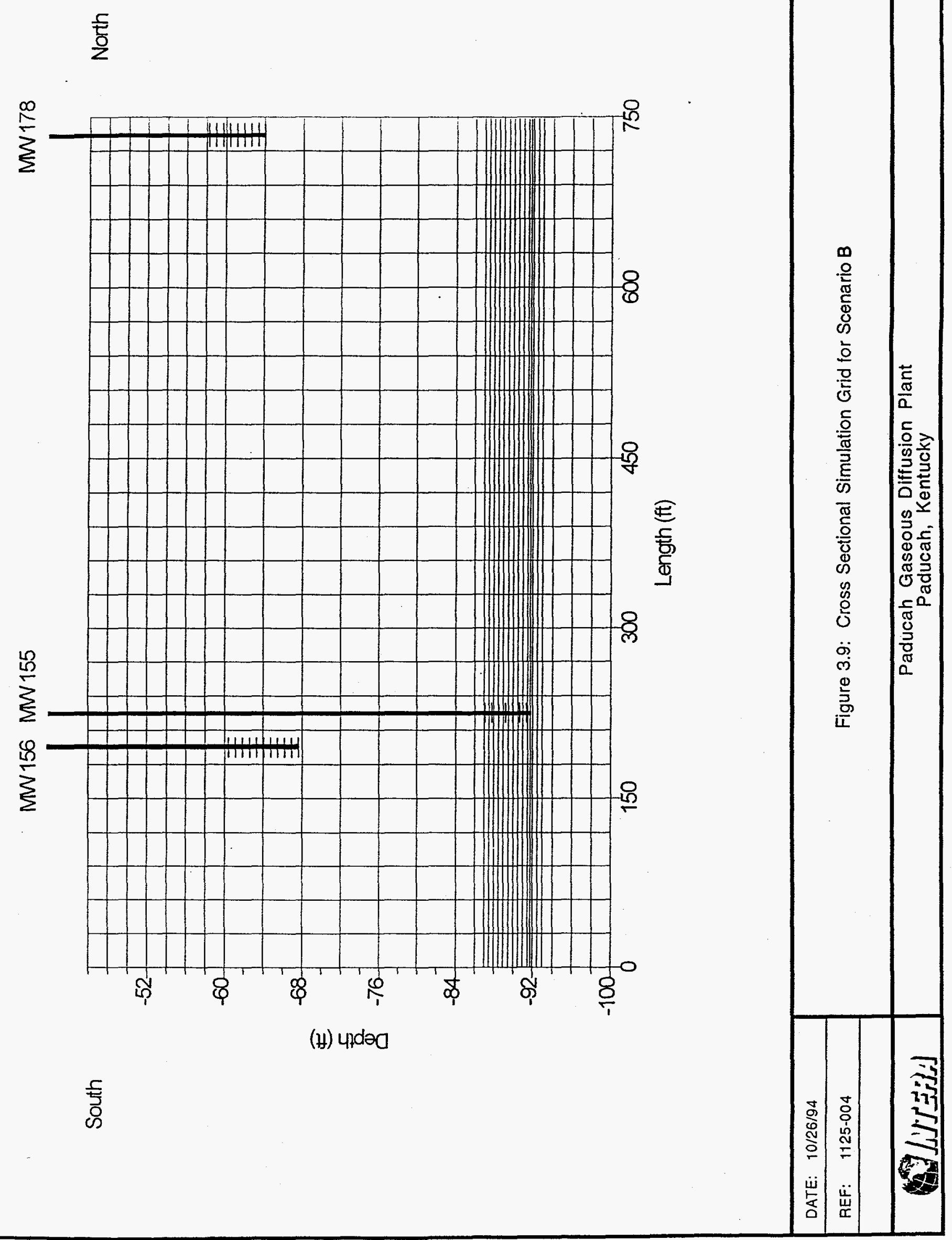




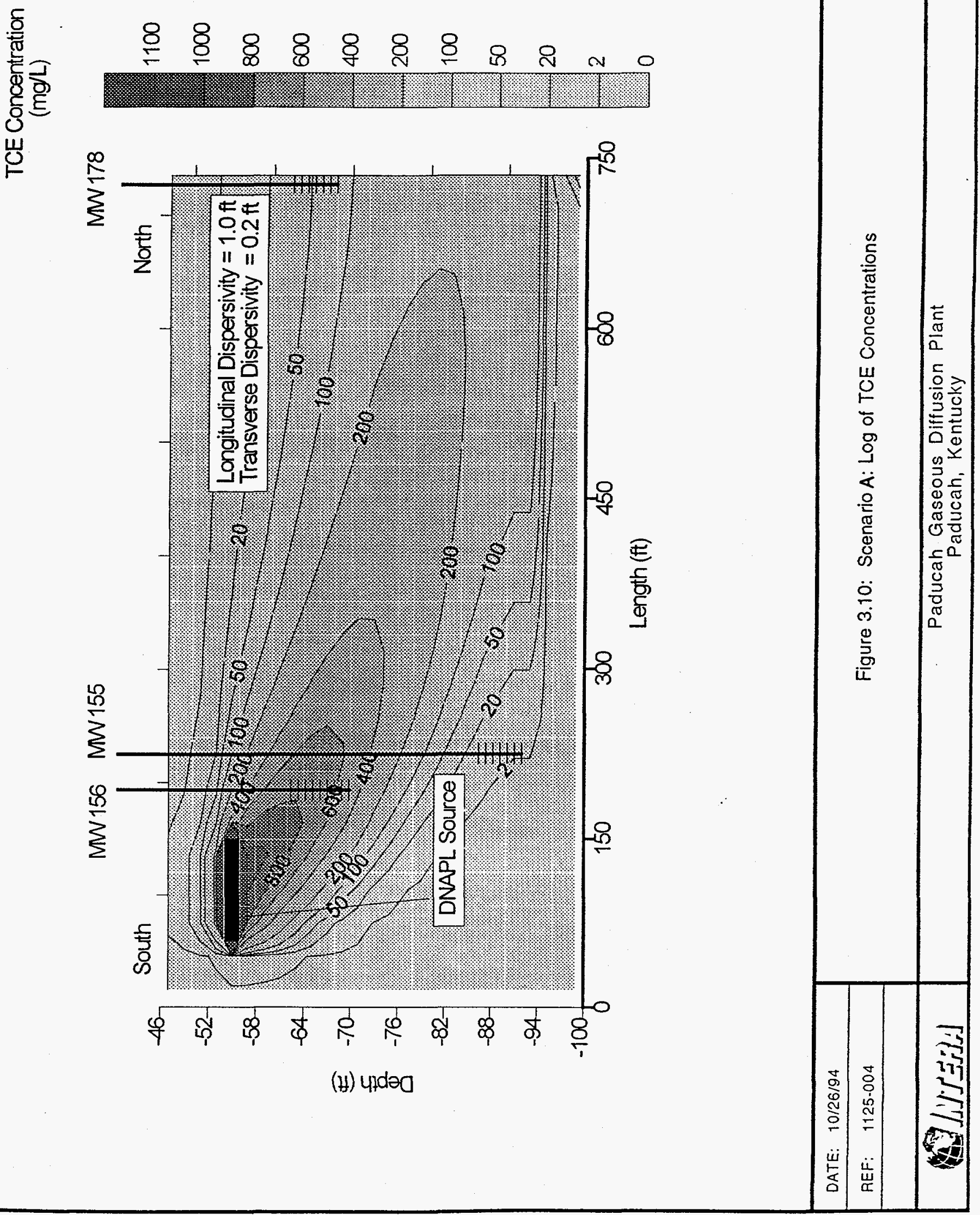




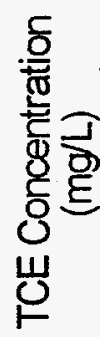
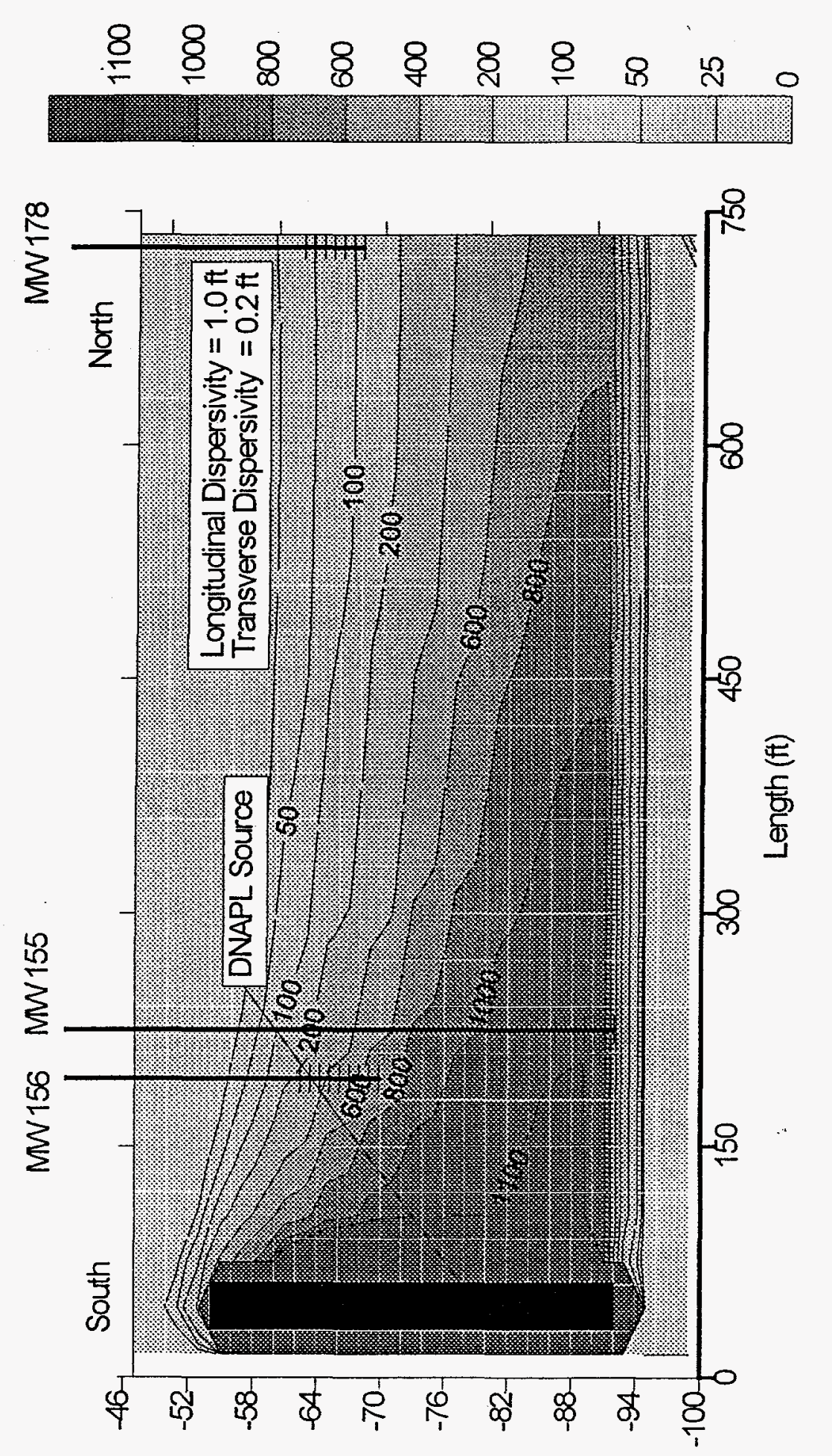

(甘) undaO

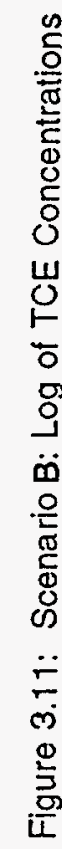




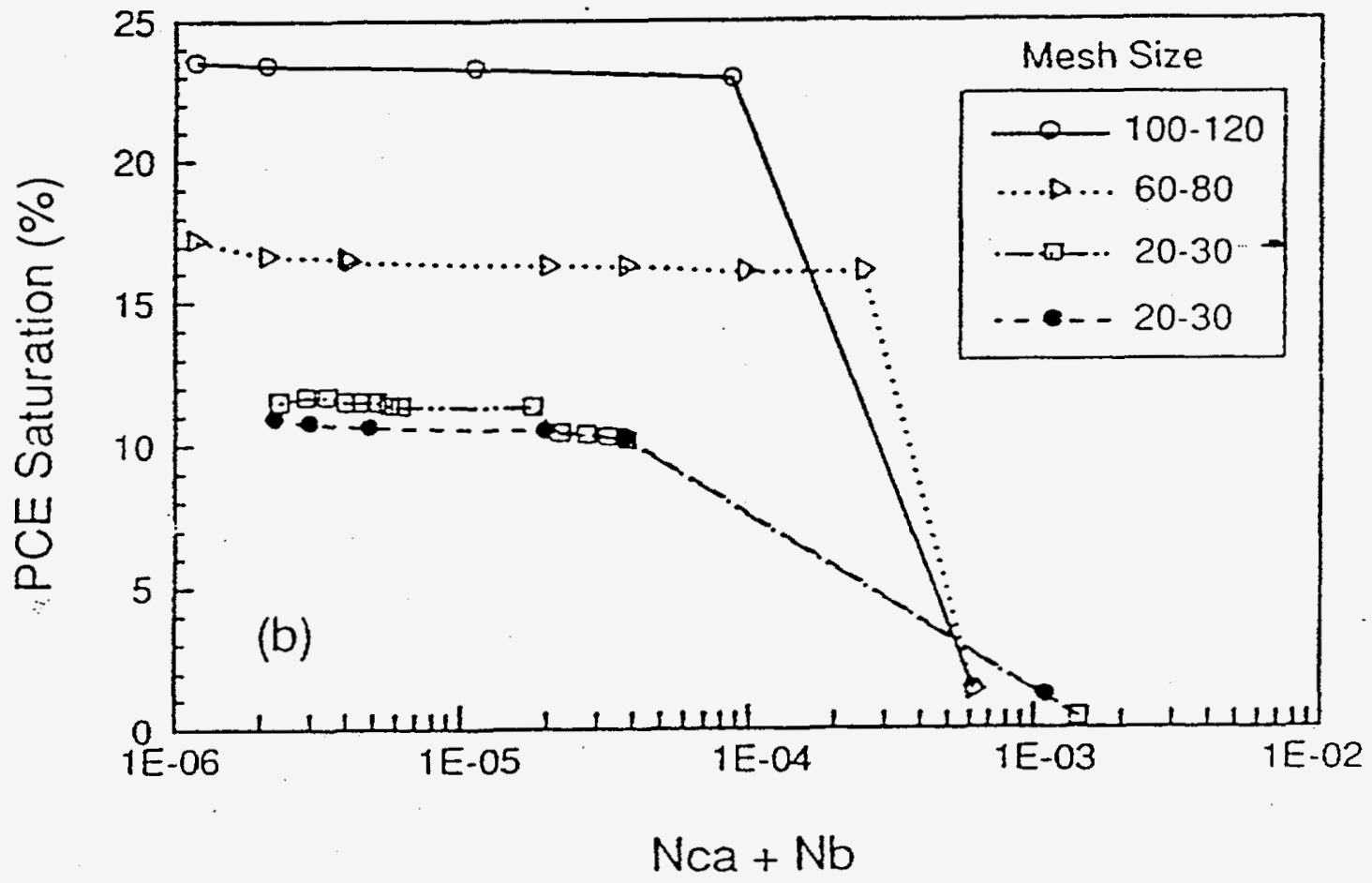

DATE: $\quad 10 / 26 / 94$

REF: $1125-004$
Figure 4.1: PCE desaturation curves following the injection of water and surfactant solutions into soil columns containing different size fractions of Ottawa sand.

(after Abriola et al., 1993). 


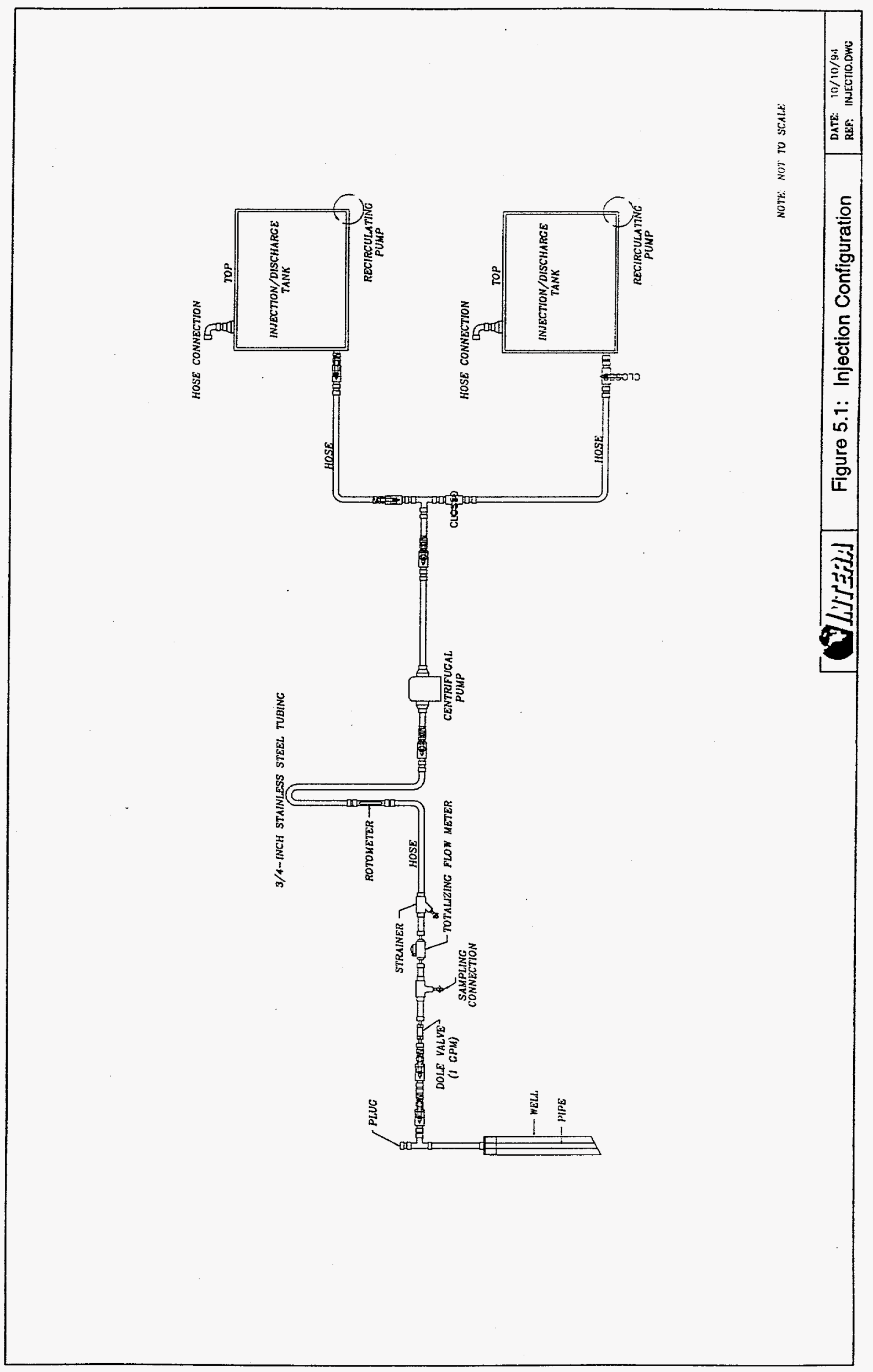




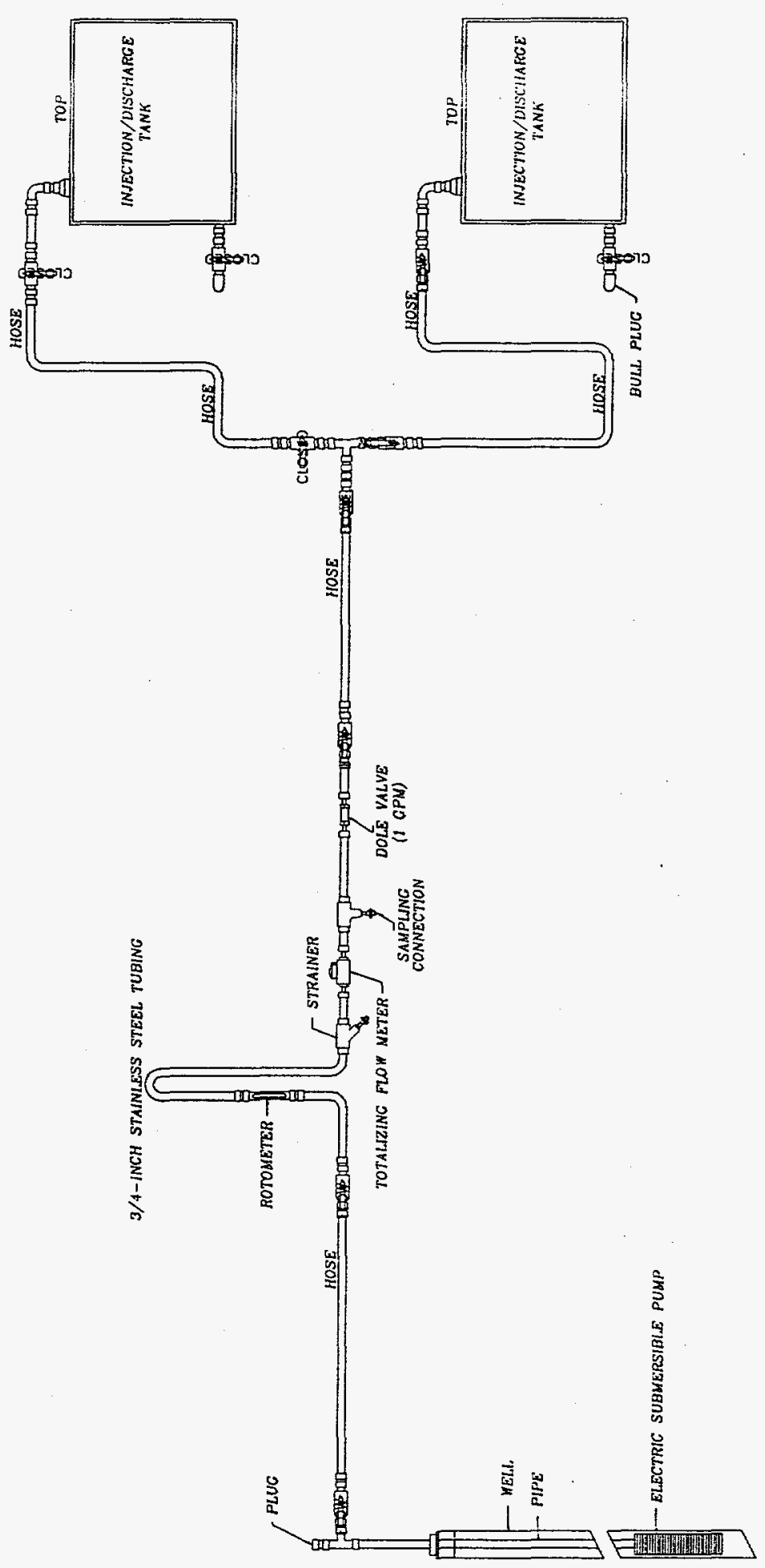

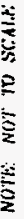




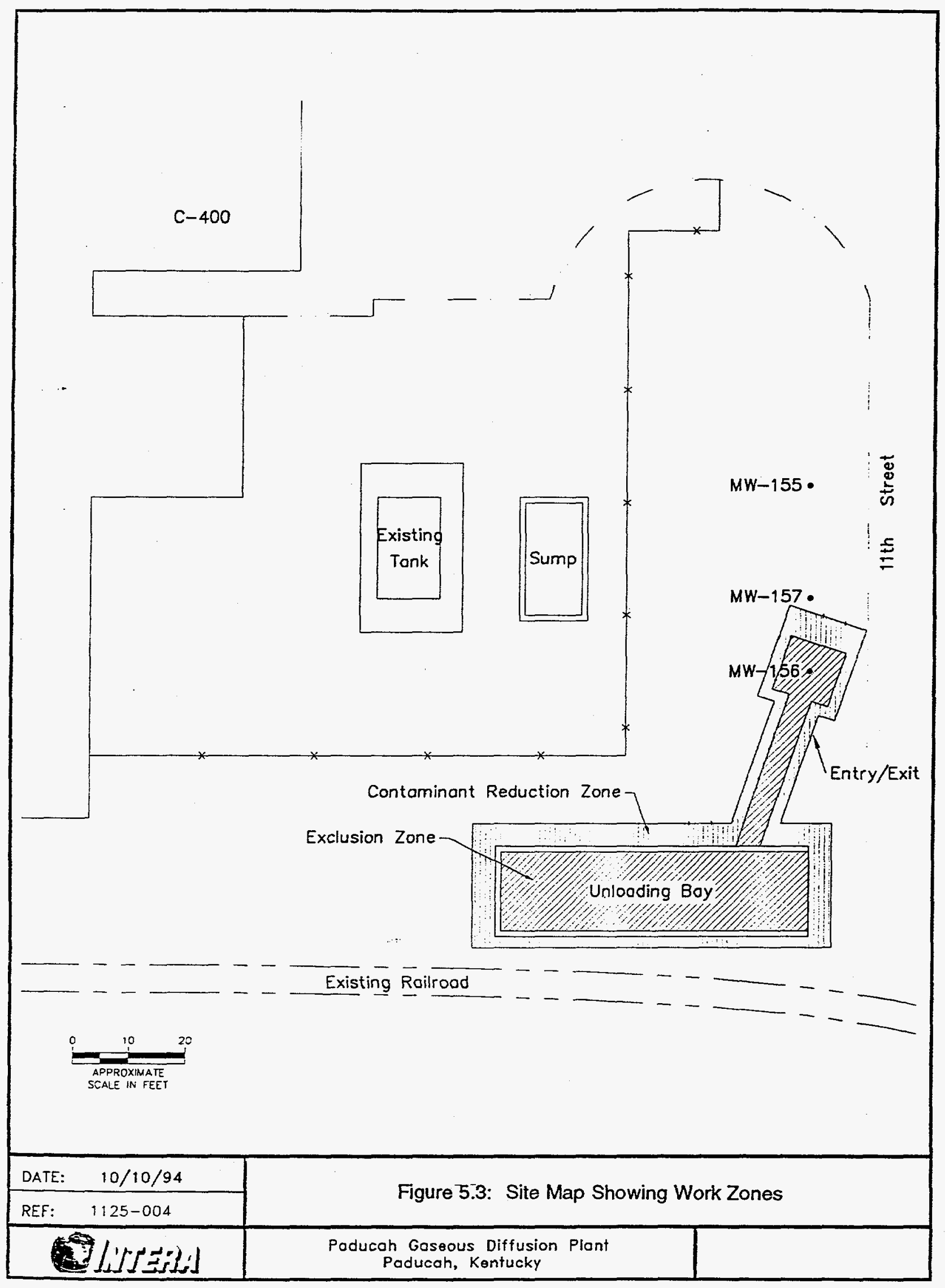




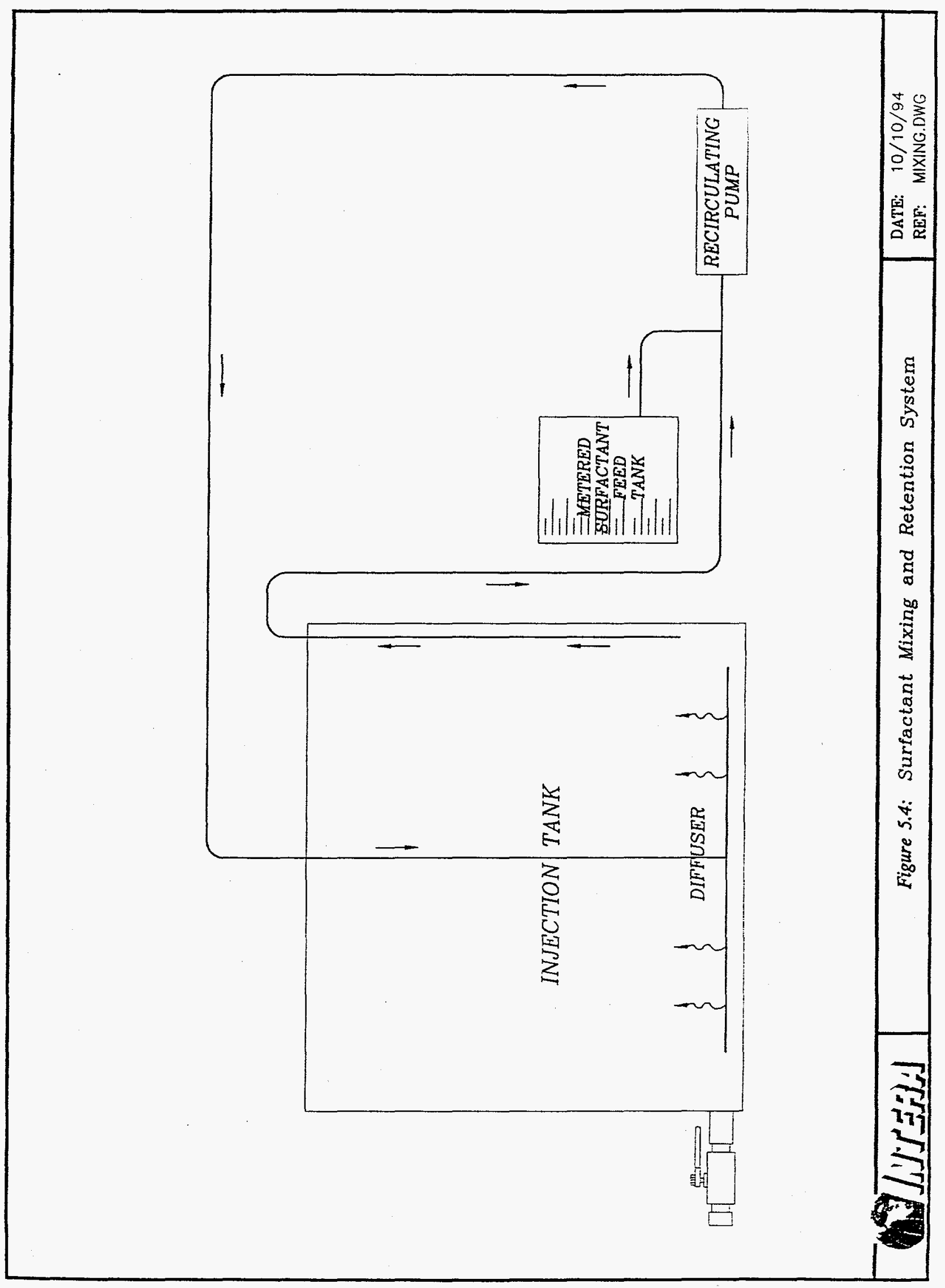




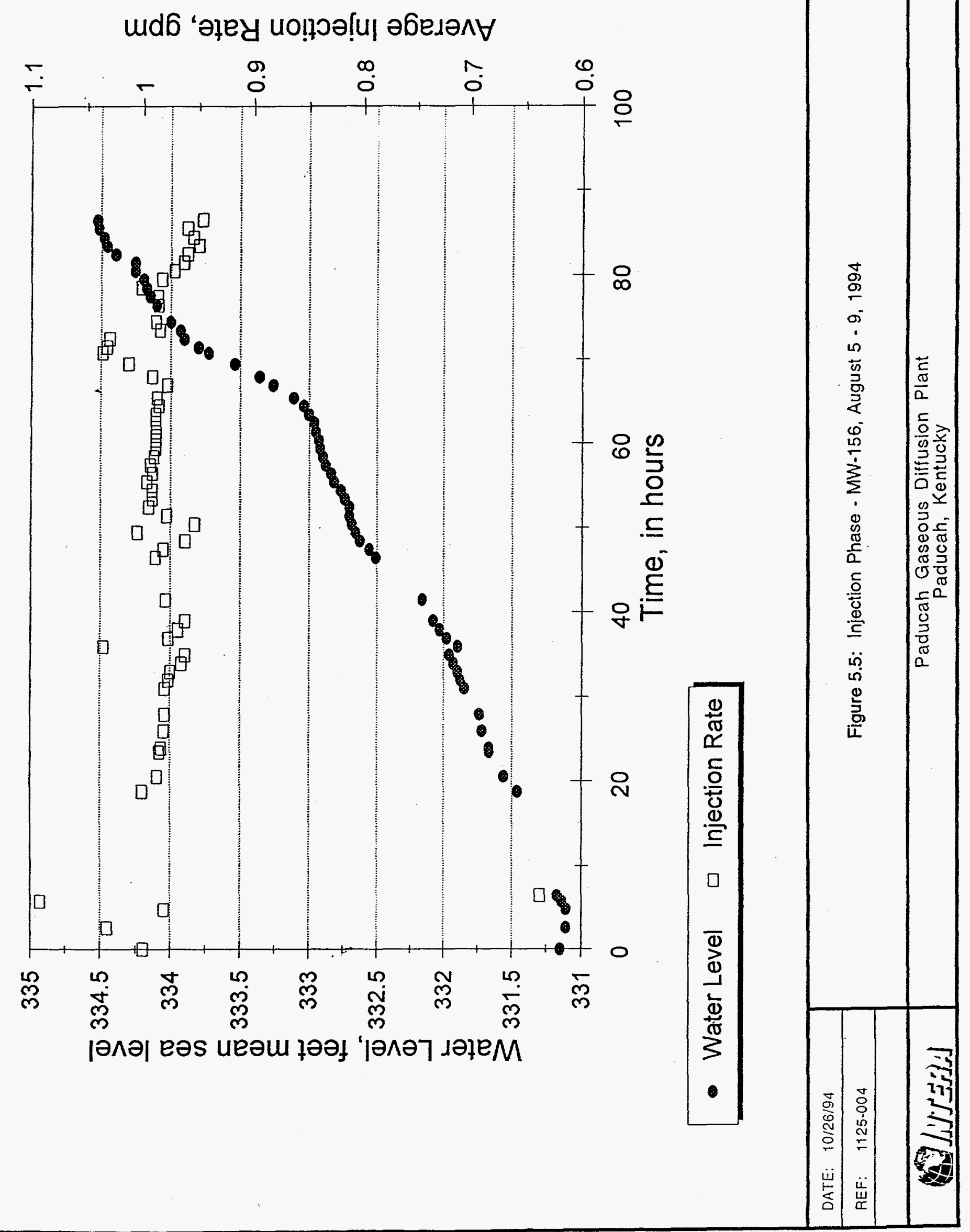




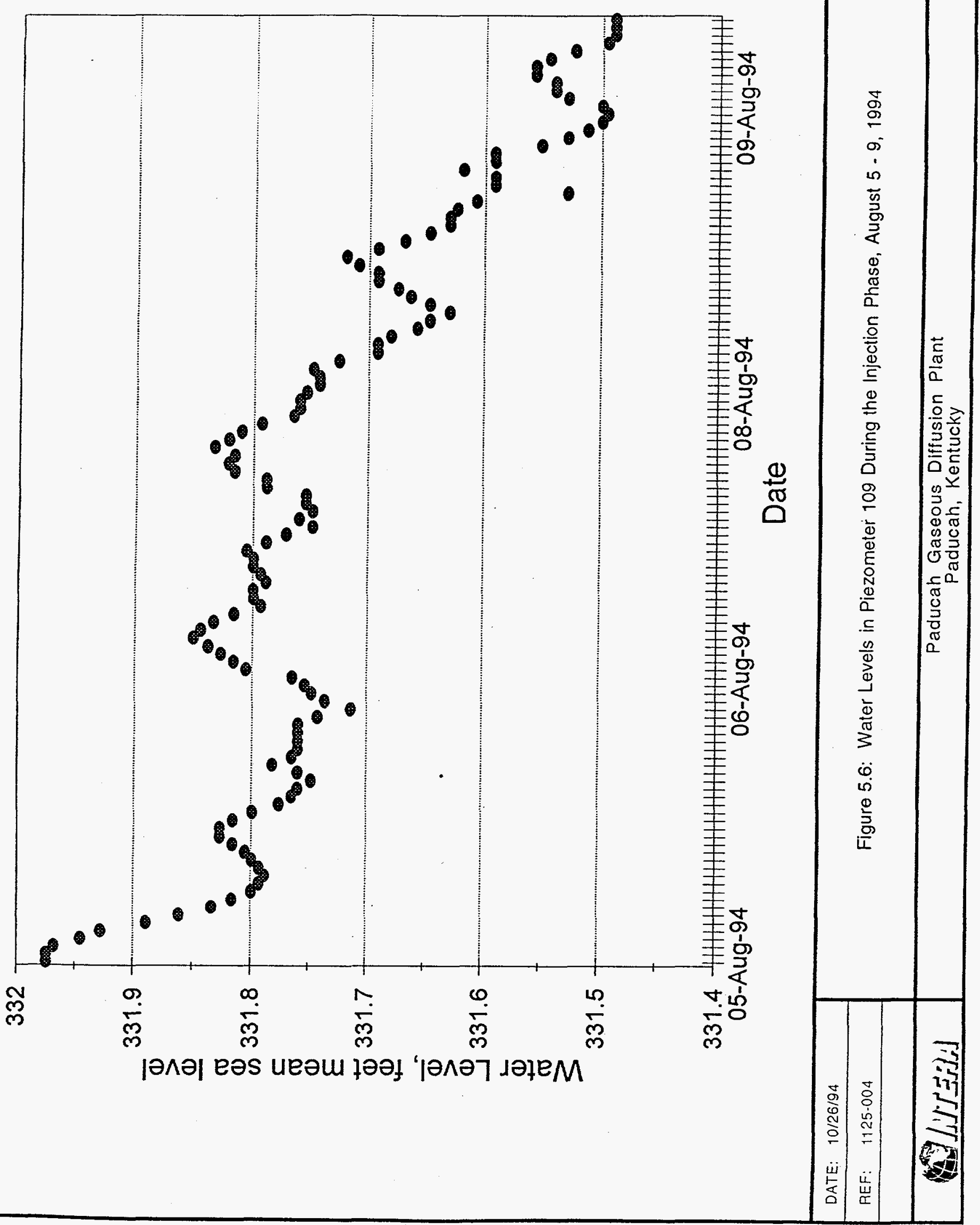




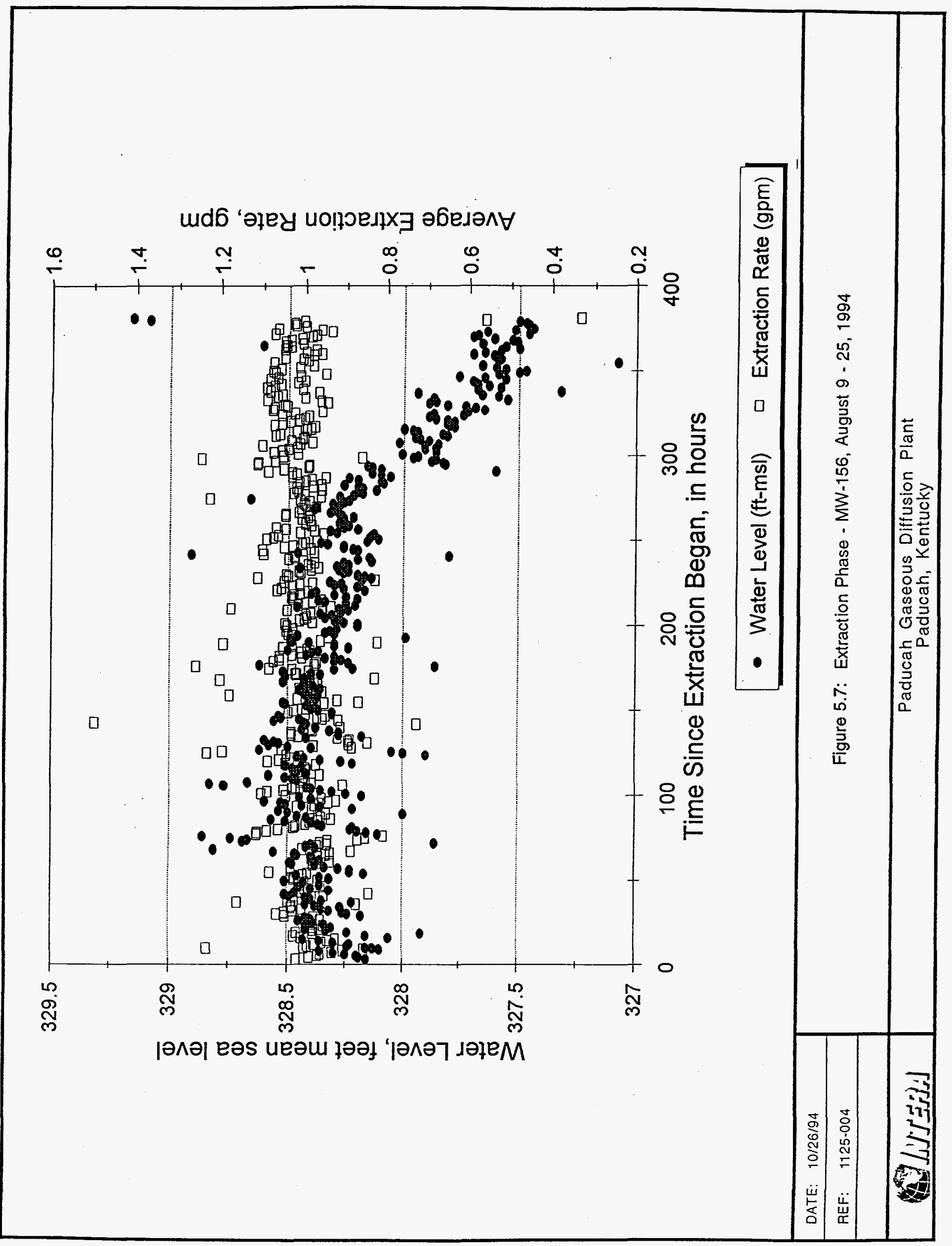




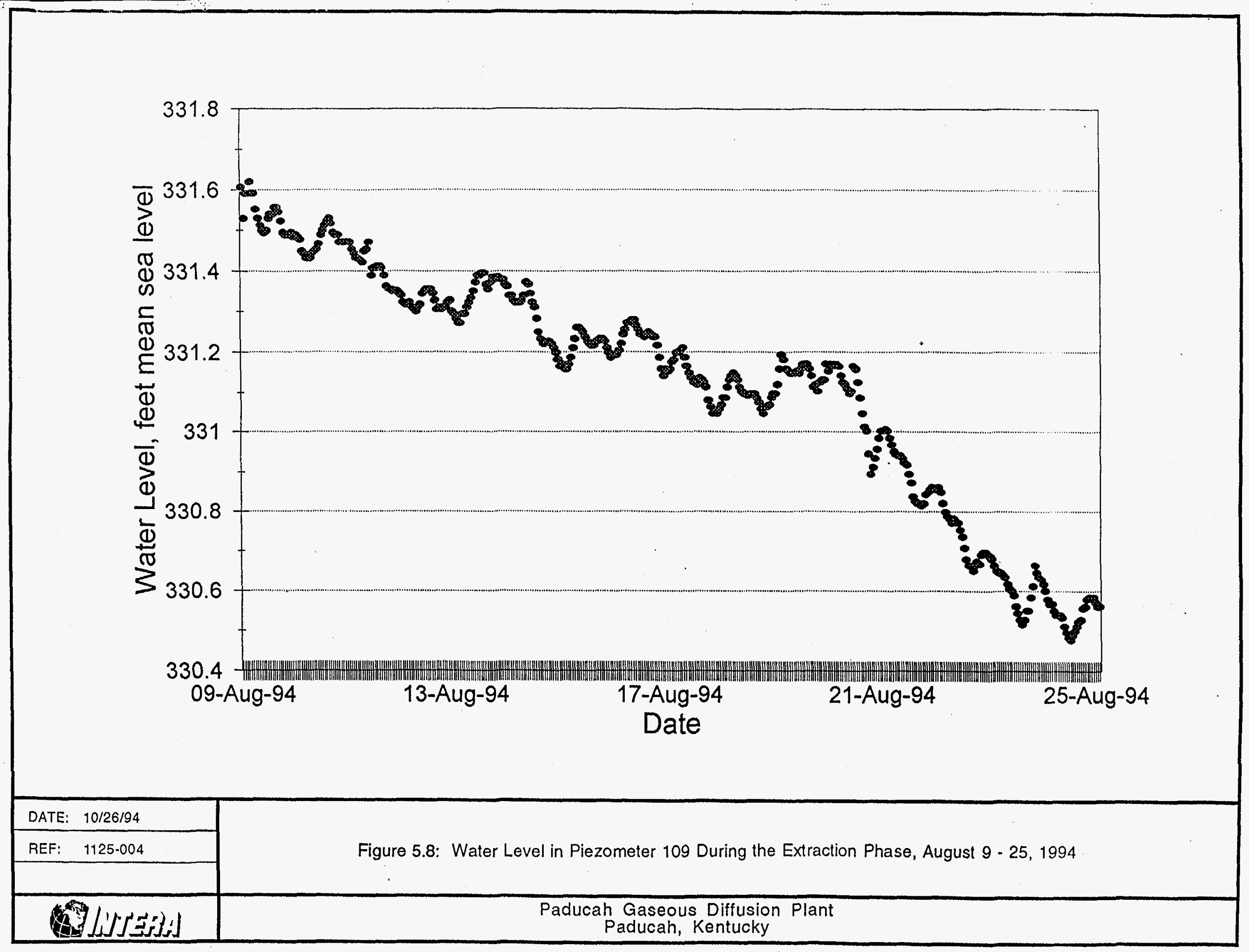




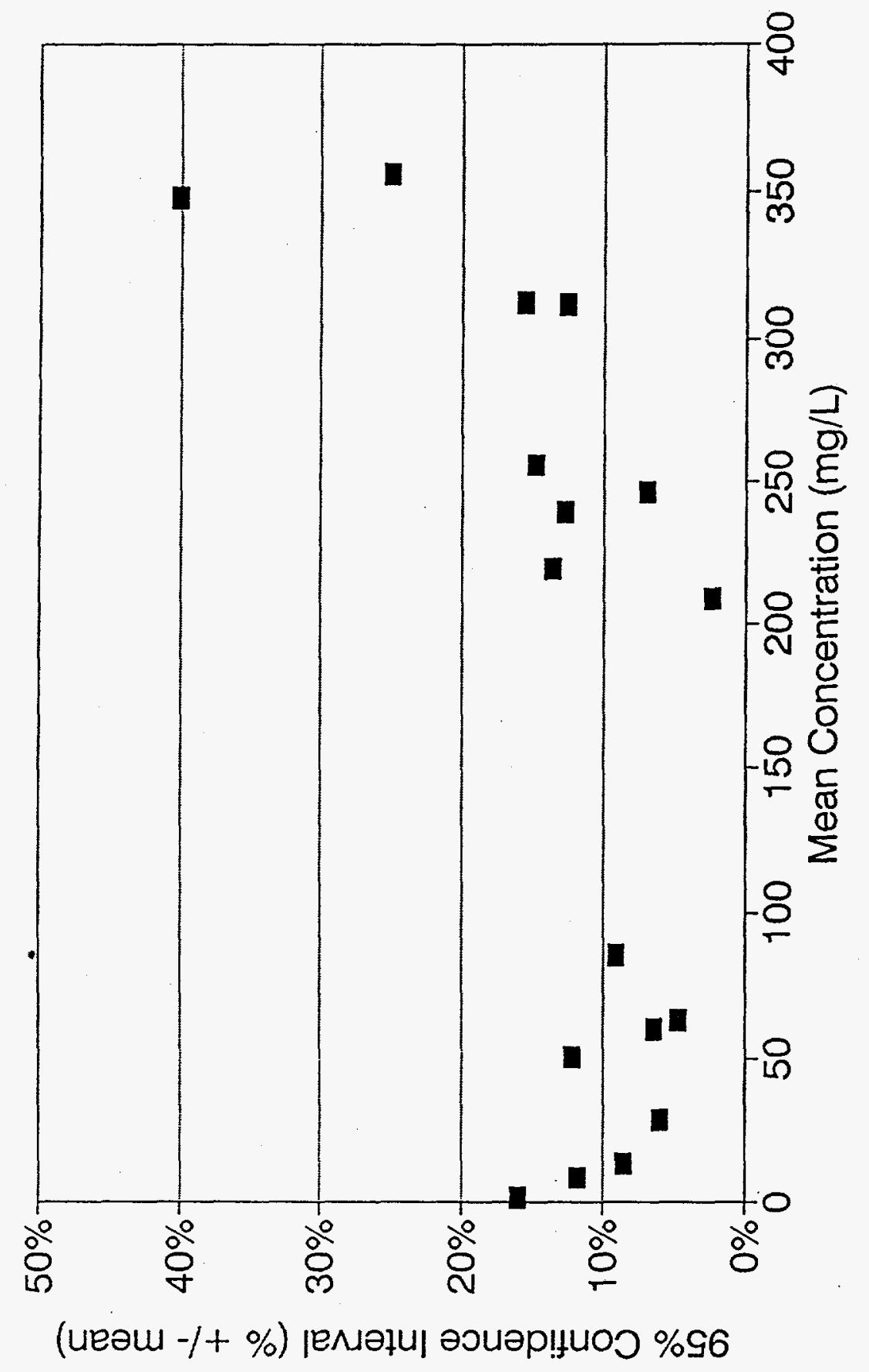

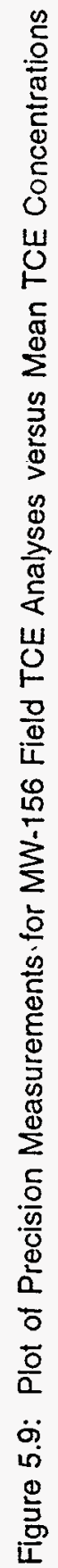




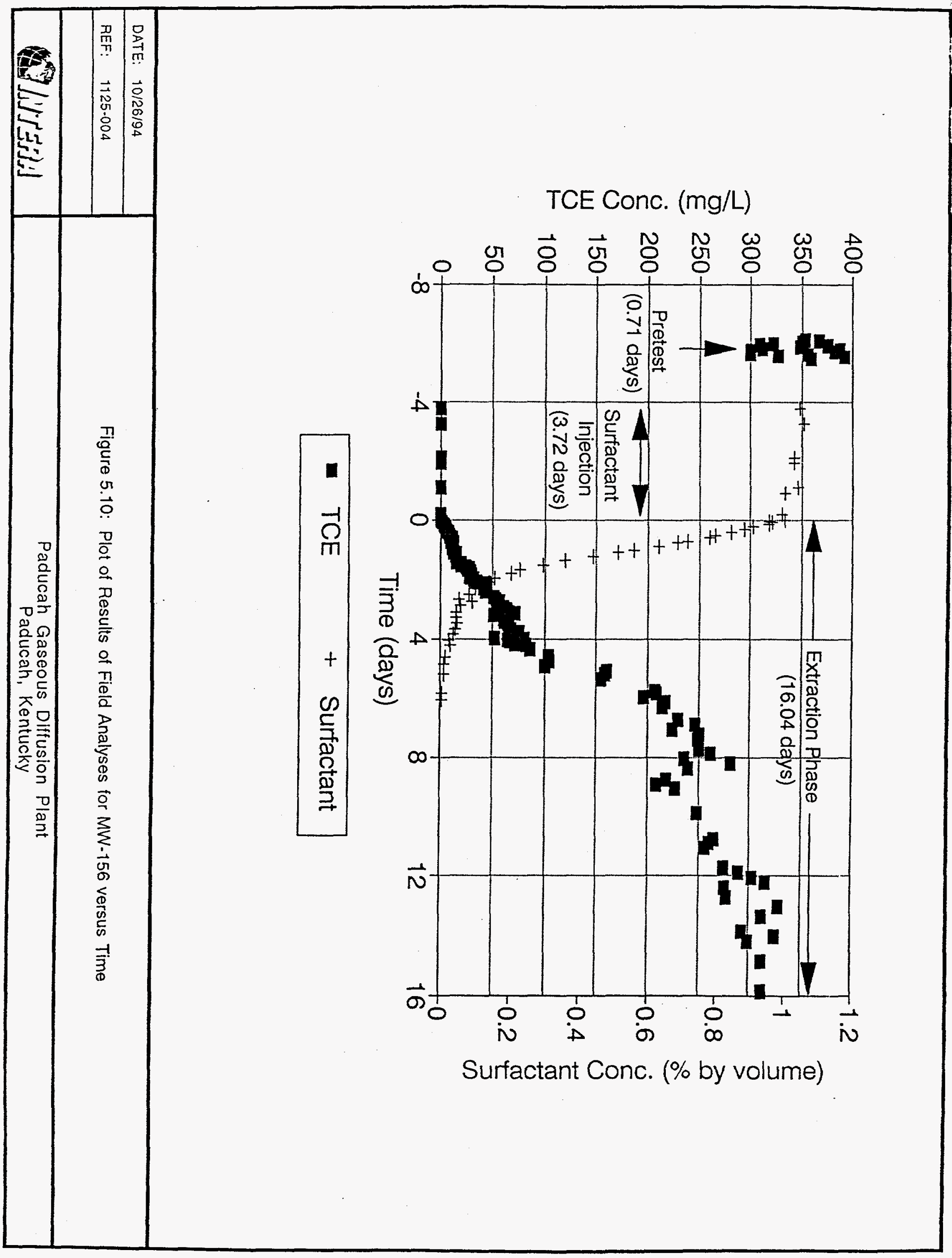




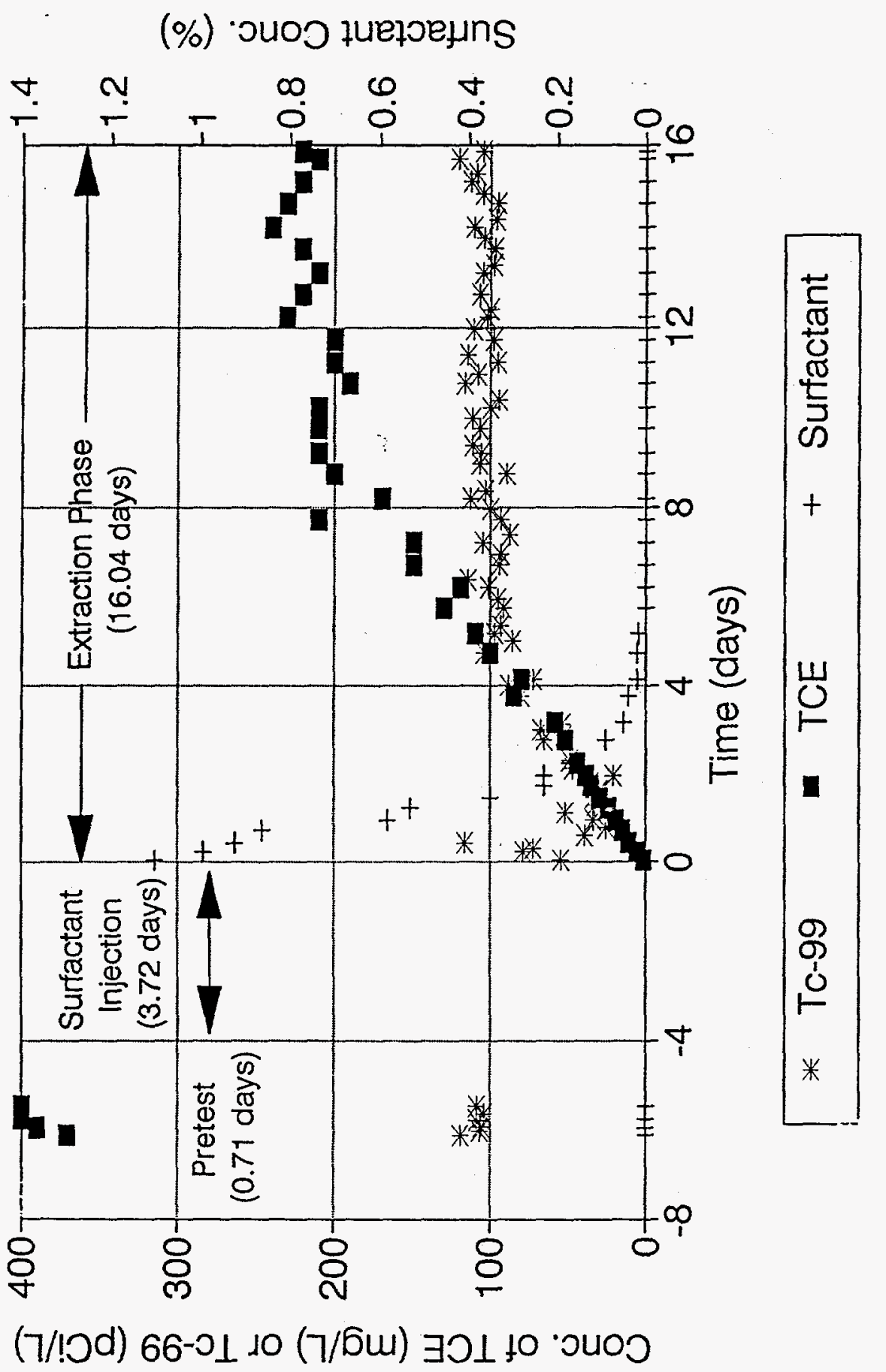

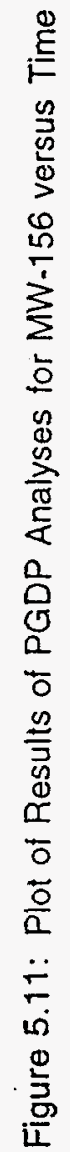

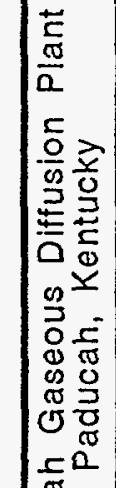
政 궁 0 


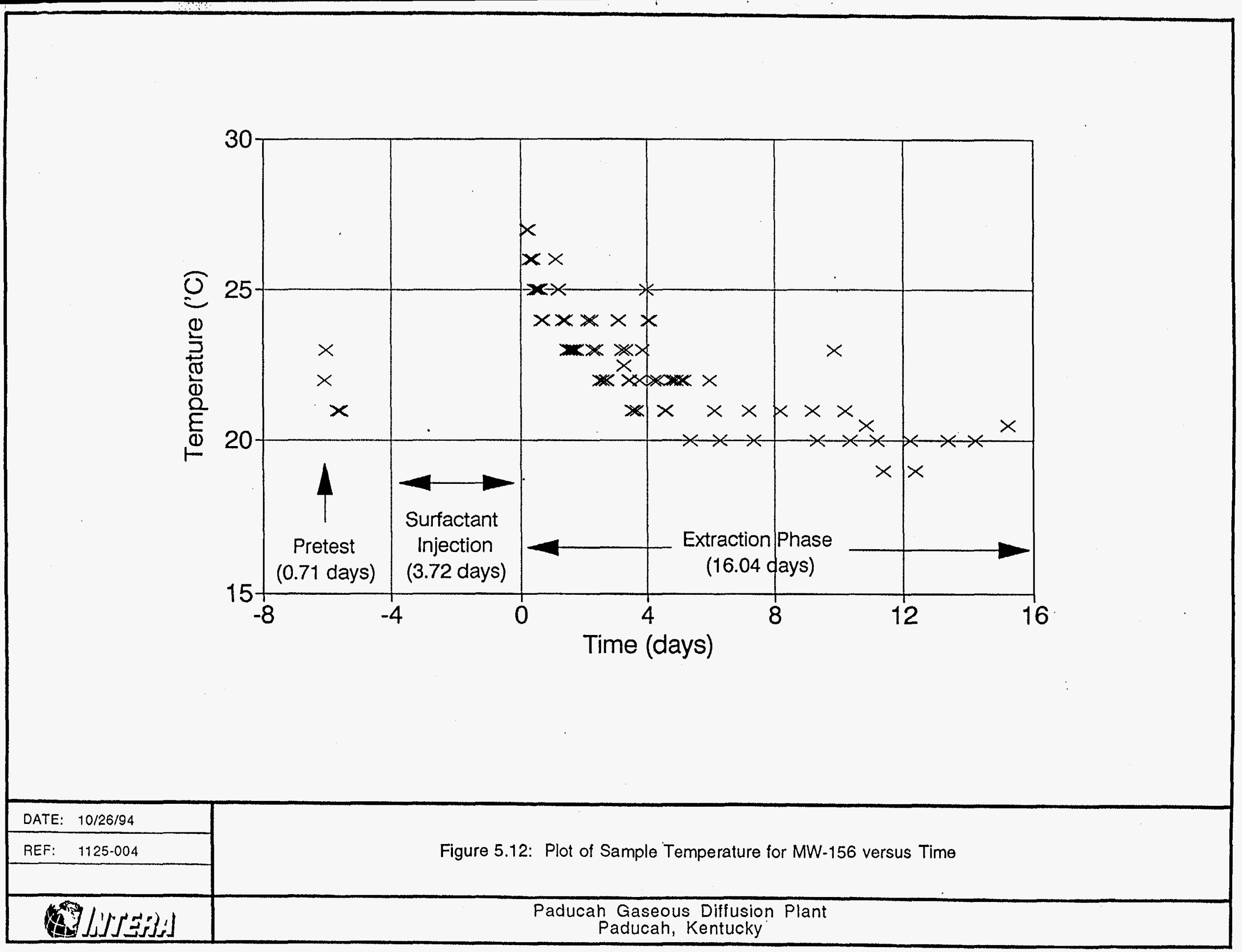




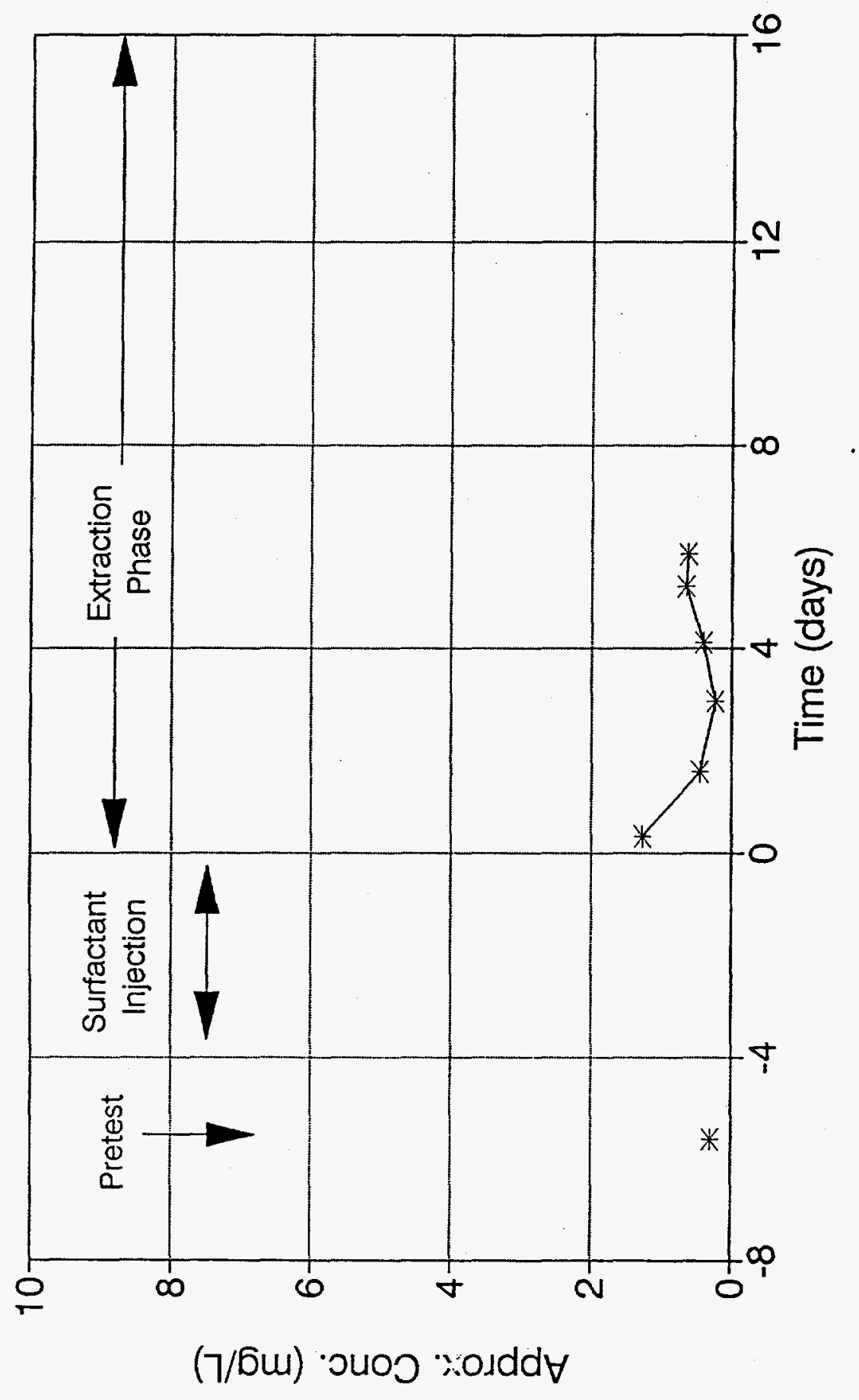




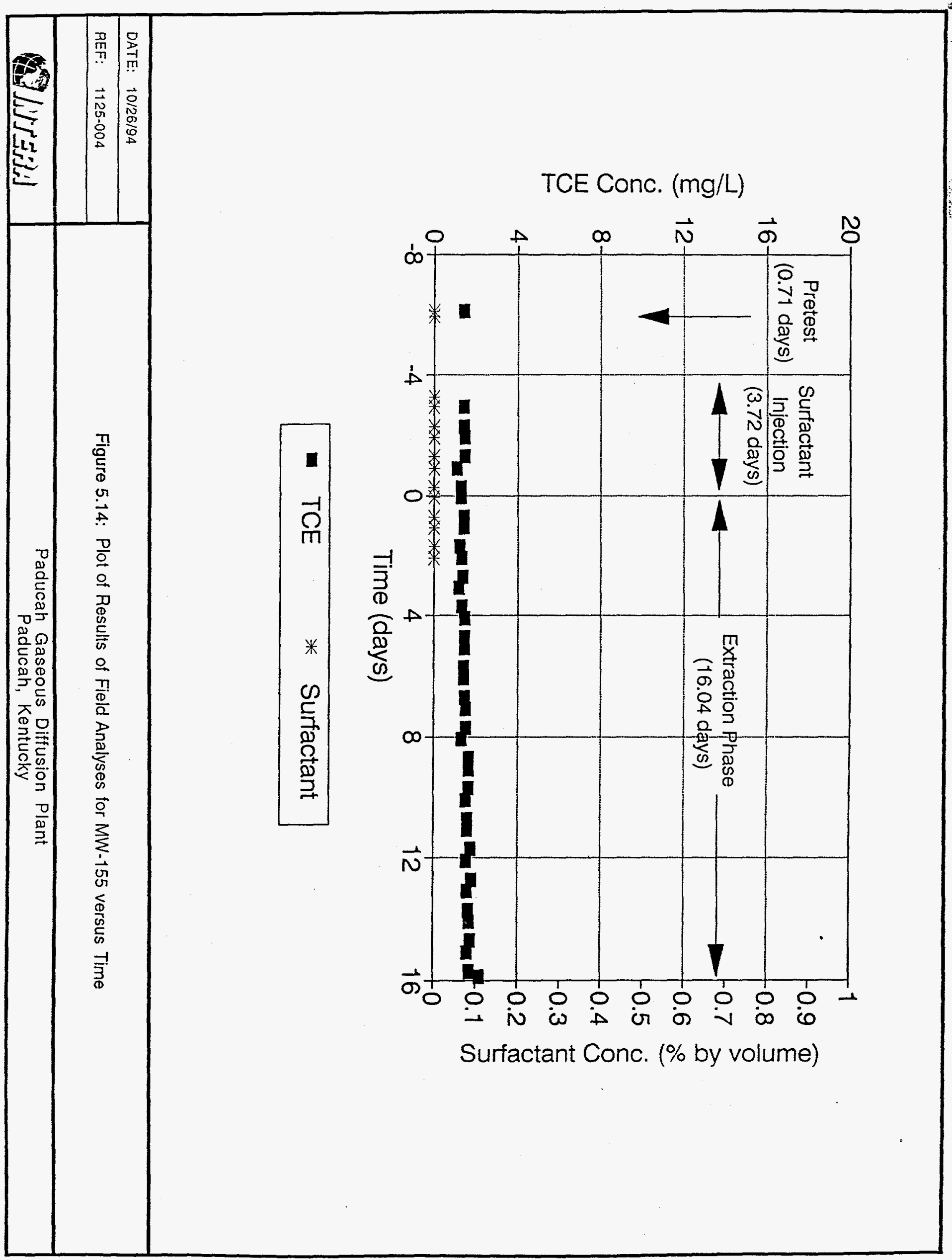




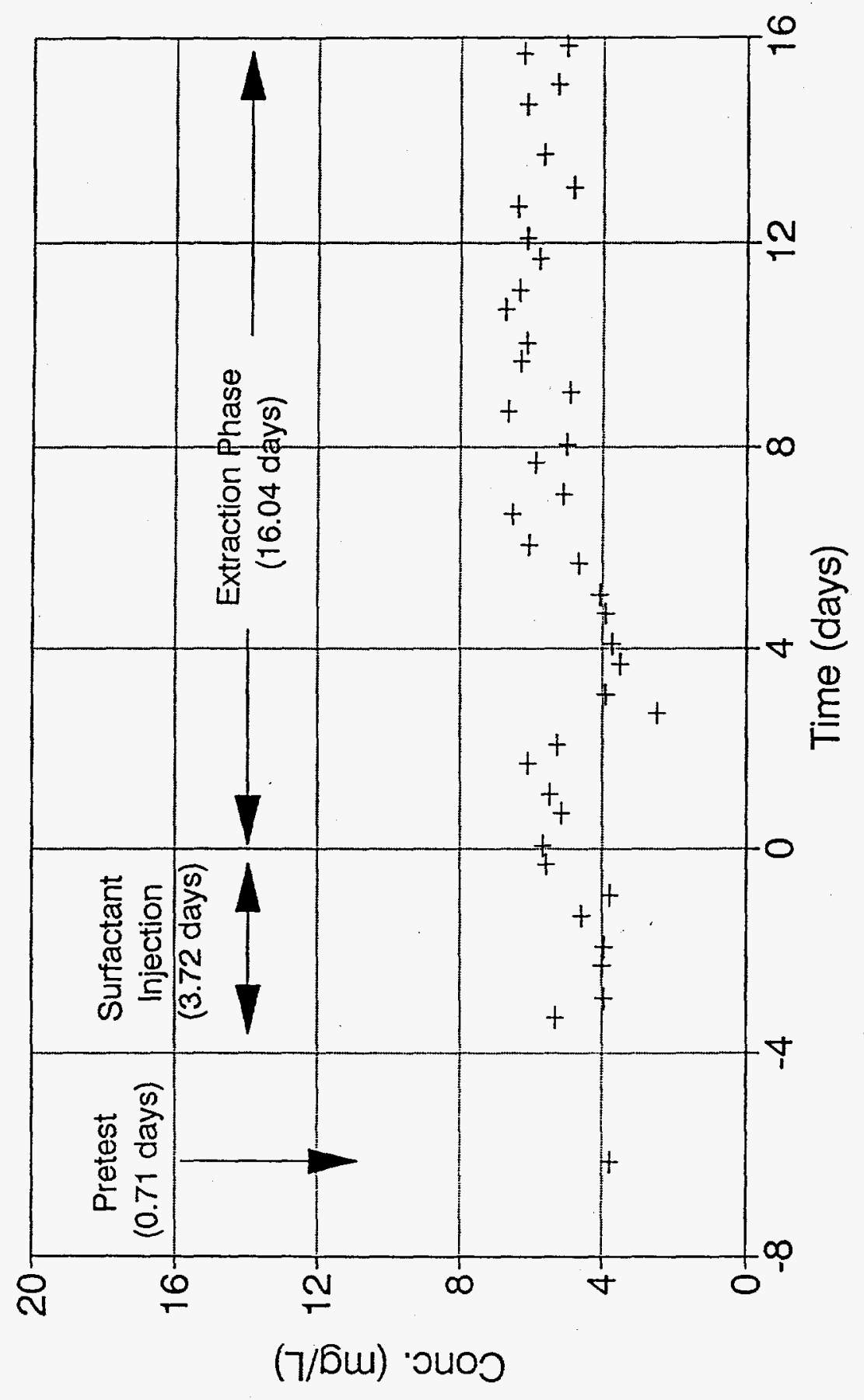

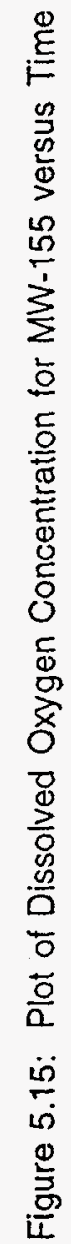




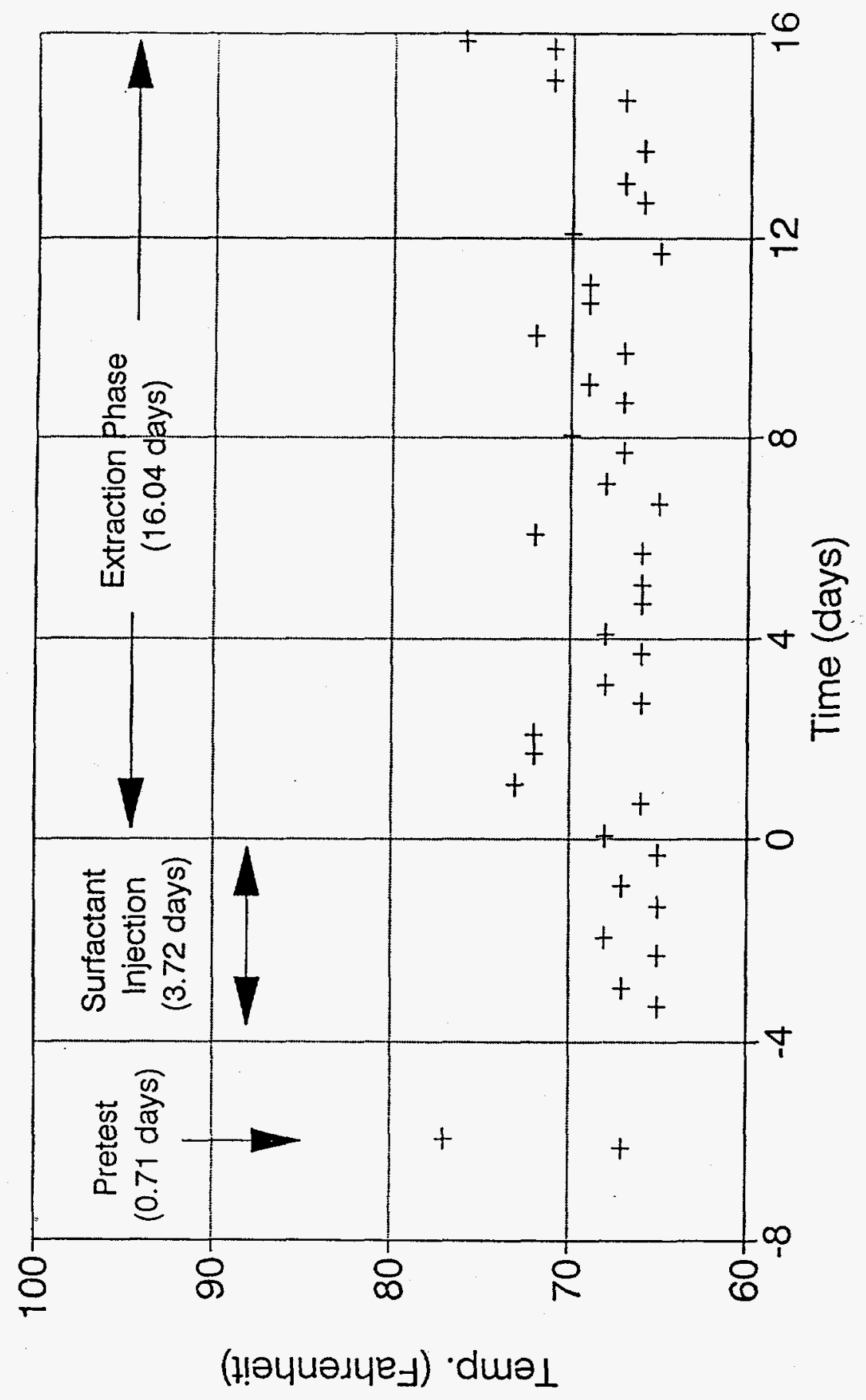

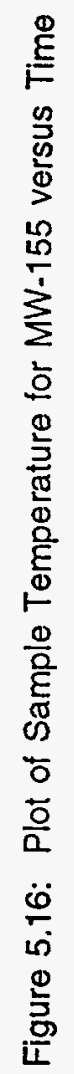

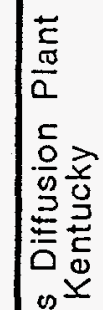
= \% 象等 $0 \frac{\pi}{0}$ =0

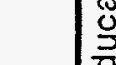
त 


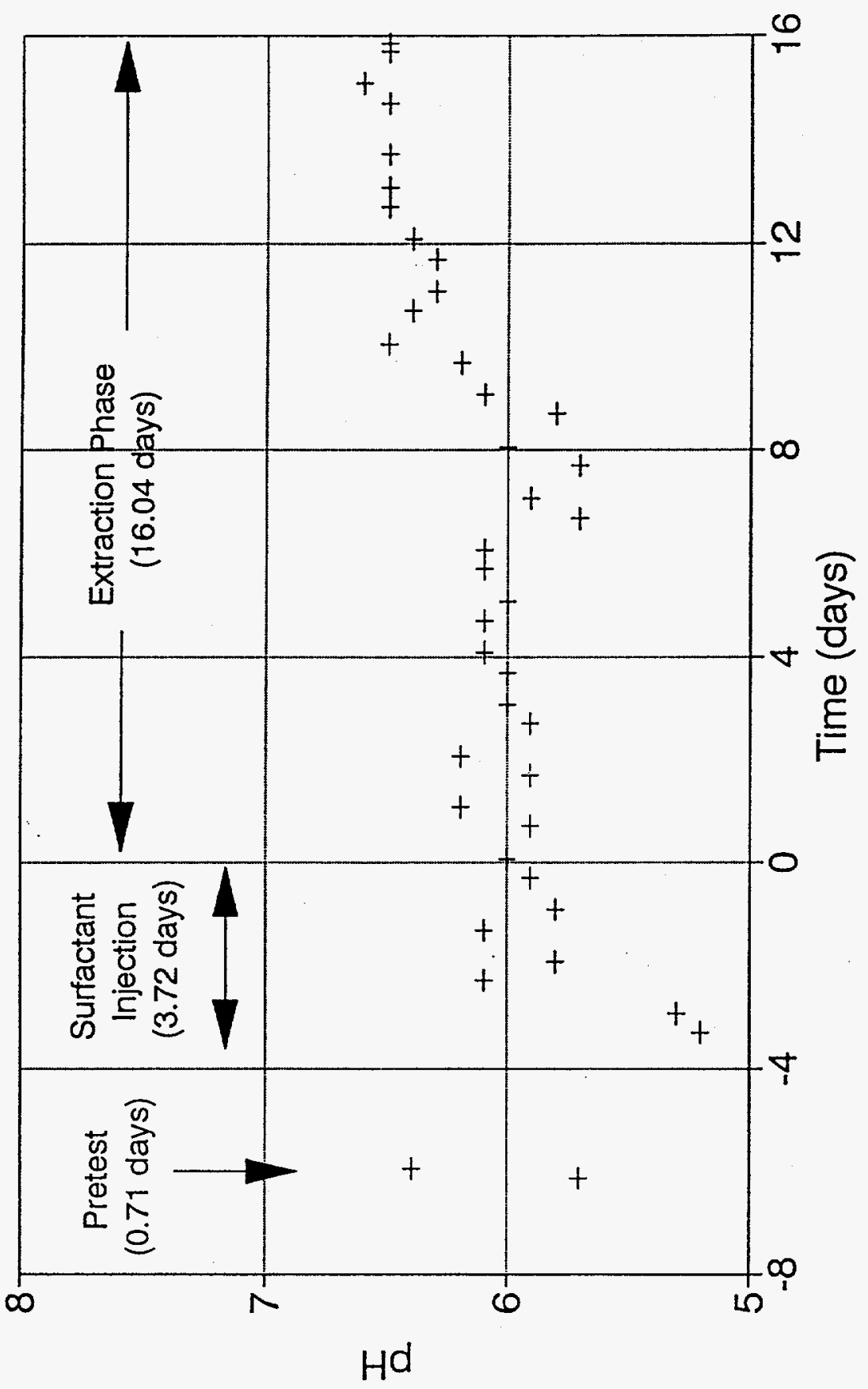

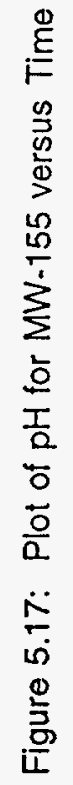




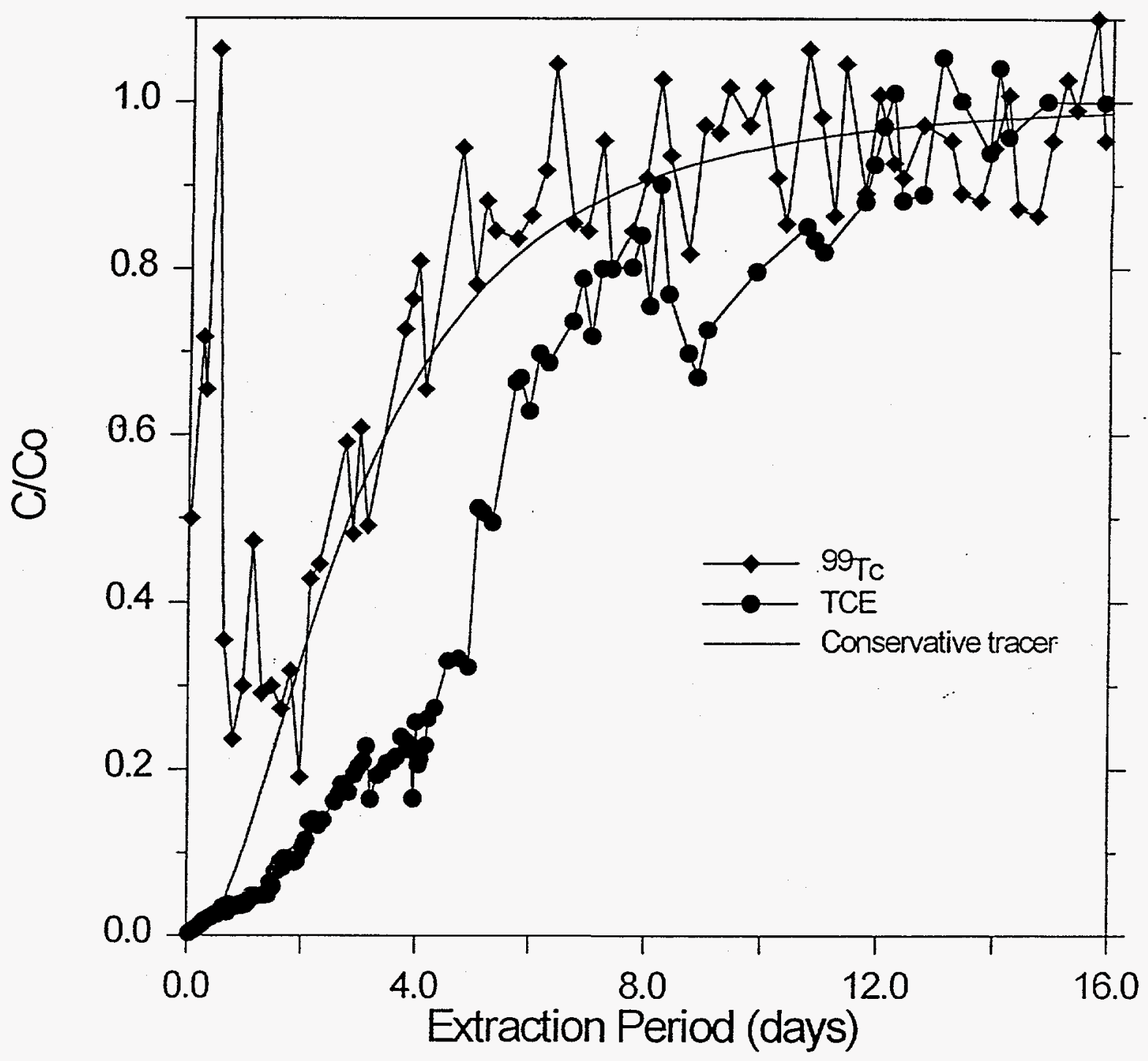

DATE: $10 / 26 / 94$

REF: $\quad 1125-004$

Figure 5.18: ${ }^{99} \mathrm{Tc}$ and TCE Response During Extraction Phase in MW-156

Paducah Gaseous Diffusion Plant Paducah, Kentucky 


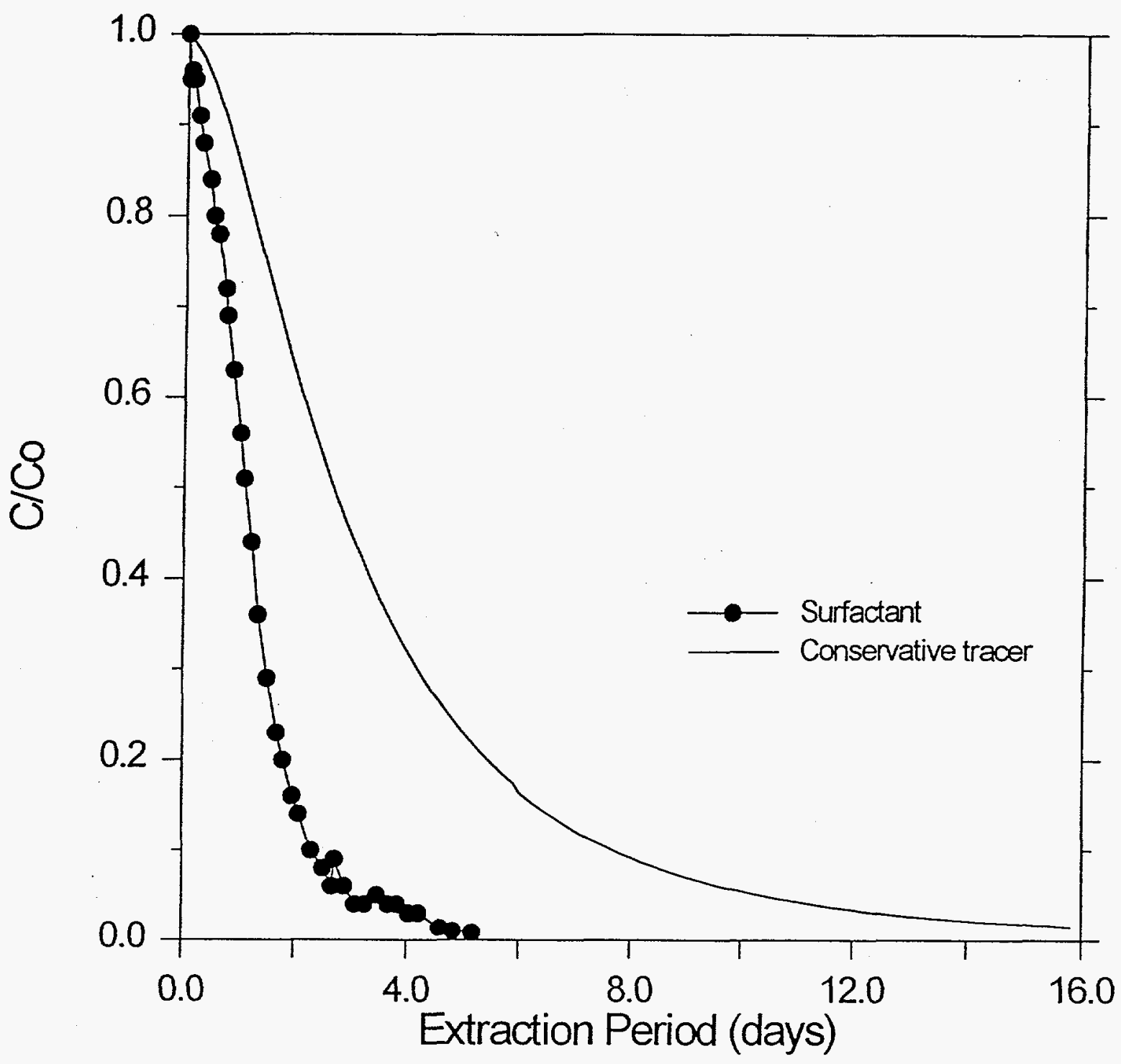

DATE: $10 / 26 / 94$

REF: $\quad 1125-004$

Figure 5.19: Surfactant recovery during extraction phase compared with that of a conservative tracer.

Paducah Gaseous Diffusion Plant Paducah, Kentucky 


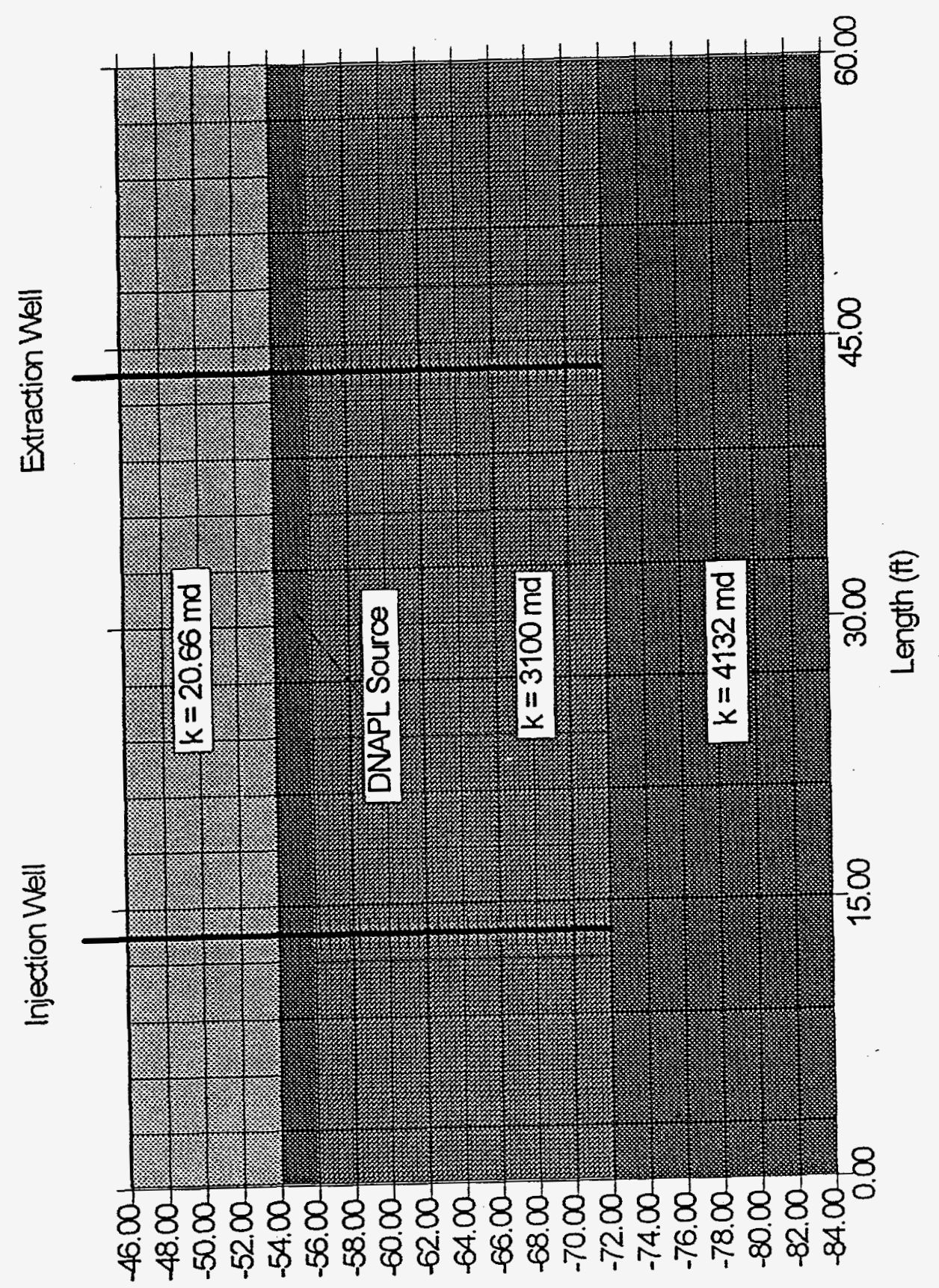

(अ) पida 


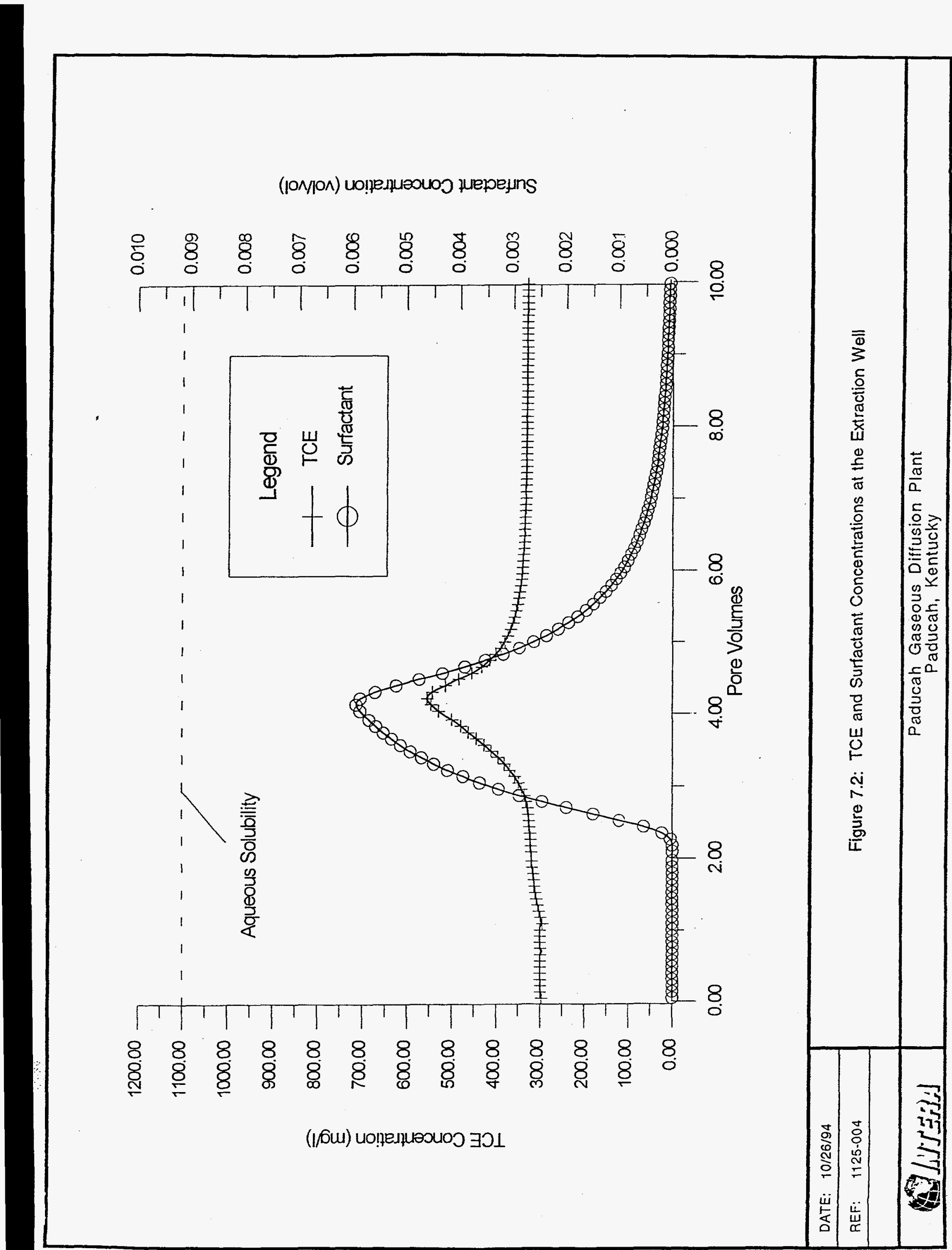


Appendix A

T-MAZ 80K
Material Safety Data Sheet 


\section{echnical bulleti T-MAZ ${ }^{\circledR} 80 \mathrm{~K}$ POLYSORBATE $80 \mathrm{~K}$}

\section{GENERAL STATEMENT:}

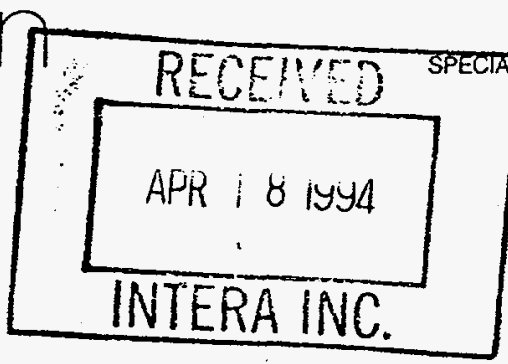

PPG INDUSTRIES. INC

CALS, CHEMICALS GROUP 3938 PORETT DRIVE TEL: (708) 244-3410 TELEX: 25-3310 FAX: (708) 244-9633

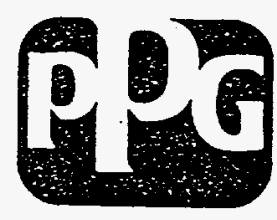

T-MAZ $80 \mathrm{~K}$ is a sorbitan monooleate which has been ethoxylated with approximately 20 moles of ethylene oxide to give a water soluble, oil and water emulsifier. This product is one of a group of ethoxylated sorbitan fatty acid esters which are often referred to as Polysorbates. These surfactants are mixtures of partial esters of sorbitol and its anhydrides made from fatty acids, such as, tall oil, lauric, palmitic, stearic and oleic, which are then reacted with ethylene oxide, to make them hydrophilic in nature. Some T-MAZ products are designated with an "FG" in the product name, which means they are food grade. This product is marked " $K$ ". which means it is food grade with Kosher $U$ Certification.

\section{APPLICATIONS:}

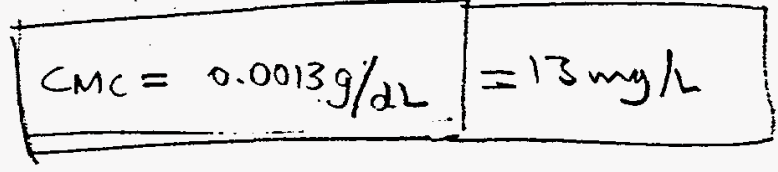

T-MAZ $80 \mathrm{~K}$ can be used as a solubilizer and emulsifier of essential oils and fragrances, as a wetting agent, viscosity modifier, anti-stat, stabilizer and dispersing agent. Typical applications are found in baby shampoos because of very low eye irritation, cosmetics and toiletries and ointments. T-MAZ surfactants can also be used in the food, pharmaceutical, textile, and metalworking industries.

\section{SOLUBILITIES:}

T-MAZ surfactants are generally soluble or dispersible in water, and, soluble in varying degrees in organic liquids. They are used for oil-in-water emulsions, dispersions or solubilizing oils and to make anhydrous ointments water soluble or washable. Frequently, the T-MAZ surfactants are combined with similarly numbered S-MAZ surfactants to promote emulsion stability.

\section{SALES SPECIFICATIONS}

\author{
ACID VALUE \\ SAPONIFICATION VALUE \\ HYDROXYL VALUE \\ WATER, $\%$ \\ RESIDUE ON IGNITION, $\%$ \\ POE, \% \\ APPEARANCE @ $25 \mathrm{C}$ \\ PPm, 1,4 DIOXANE \\ ARSENIC, PPM \\ HEAVY METALS, $\%$
}

$2 \operatorname{MAX}$

45-55

$65-80$

3 MAX

0.25 MAX

65-69.3

CLEAR YELLOW LIQUID

1 MAX

$1 \operatorname{MAX}$

0.001 MAX

\footnotetext{
This product is available in bulk, drum, and 5 gallon pail quantities

last revised 01 DEC 1993 DBM/RGL Technical Service Dept.
}

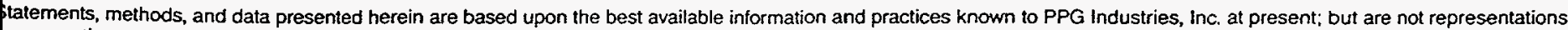

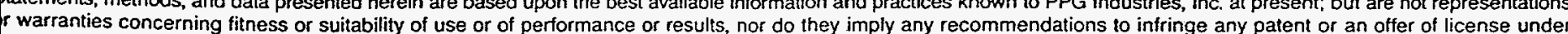
y patent.

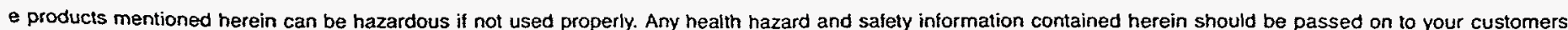

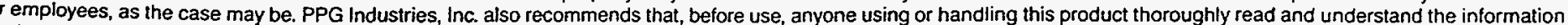
nd precautions on the label as well as in other product safety publications, such as the Material Safety Data Sheet.

e all potentially hazardous materials, this product must be kept out of the reach of children. 
PPG ${ }^{\circledR}$ INDUSTRIES, INC.

Specialty Chemicals

3938 Porett Drive Gurnee, IL 60031

informational phone number: (800) 552-1912

24 hour emergency phone number: (304) 843-1300

\section{MATERIAL SAFETY DATA SHEET}

\section{PRODUCT INFORMATION}

Trade Name: T-MAZ $80 \mathrm{~K}$

Name and/or Family or Description: POLYSORBATE $80 \mathrm{~K}$

DOT Hazard Classification: NON-HAZARDOUS

DOT:

NFPA:HEALTH HAZARD-0-NORMAL MATERIAL; FLAMMABILITY-1-ABOVE 200 DEG F.; REACTIVITY-0-STABLE

CAS NUMBER:

RCRA HAZARD CLASS: (IF DISCARDED)

$9005-65-6$

EPA PRIORITY POLLUTANTS

SARA TITLE III (SeC. 313) HAZARDOUS MATERIAL

NON-HAZARDOUS

NONE

NONE

\section{HAZARDOUS INGREDIENTS}

(This material contains no ingredients which are known by PPG Industries to be hazardous unless listed below).

\section{MATERIAL OR COMPONENT}

NONE KNOWN

ILV (UNITS)

APPROX $\%$

As established by the American Conference of Governmental Industrial Hygienists and/or standards promulgated by the Occupational Safety and Health Administration.

\section{PHYSICAL DATA}

BOILING POINT, OF

SOLUBILITY IN WATER @ $25^{\circ} \mathrm{C}$

SPECIFIC GRAVITY@ $25^{\circ} \mathrm{C}$

VAPOR PRESSURE, $\mathrm{mm} \mathrm{Hg}$ ¿ $25^{\circ} \mathrm{C}$

VAPOR DENSITY, $(A I R=1)$

VOLATILES, \%, BY VOLUME

APPEARANCE @ $25^{\circ} \mathrm{C}$

ODOR

FLASH POINT, PMCC, OF
$>300$

SOLUBLE

1.09

$<1$

$>1$

$<4$

CLEAR YELLOW LIQUID

BLAND

$>300$

\section{FIRE AND EXPLOSION HAZARD DATA}

Flash Point: (See PHYSICAL DATA section)

Flammable Limits in Air, \& by Volume: Unknown LOWER: Undetermined UPPER: Undetermined

Extinguishing Media: Use Carbon Dioxide or Dry Chemical on small fires. Use foam (alcohol, polymer or ordinary) and water spray for large fires.

Special Fire Fighting Procedures: Self-contained breathing apparatus and protective clothing should be worn in fighting fires involving chemicals.

Unusual Fire \& Explosion Hazards: None Known to PPG Industries. 


\section{HEALTH HAZARD DATA}

Threshold Limit Value: Not 1 isted by OSHA or ACGIH.

Effects of Overexposure: Contact with skin or eyes not expected to cause irritation.

Effects of. a Single Overexposure:

Swallowing: No evidence of adverse effects from available information.

Skin Absorption: No evidence of adverse effects from available information.

Skin Contact: No evidence of adverse effects from available information.

Eye Contact: No evidence of adverse effects from available information.

Inhalation: No evidence of adverse effects from available information.

Effects of Repeated Overexposure: No evidence of adverse effects from

available information.

Emergency and First Aid Procedures: Flush eyes with copious amounts of water for a minimum of 15 minutes. Wash contacted skin areas with soap and water. If irritation develops, consult a physician. Soaked clothing should be changed immediately! Remove to fresh air.

Medical Conditions Aggravated by Overexposure: A knowledge of available toxicology information and of the physical and chemical properties of the material suggests that overexposure is unlikely to aggravate existing medical conditions.

Significant Laboratory Data with Possible Relevance to Human Health Hazard Evaluation: None currently known unless listed below.

Oral, LD50, rat

Oral, LD50, mouse

Ocular irritation, rabbit

Dermal irritation, rabbit

Dermal, human patch test

Intraperitoneal, LD50, rat

Intraperitoneal, LD50, mouse

Intravenous, LD50, rat

Comedogenicity

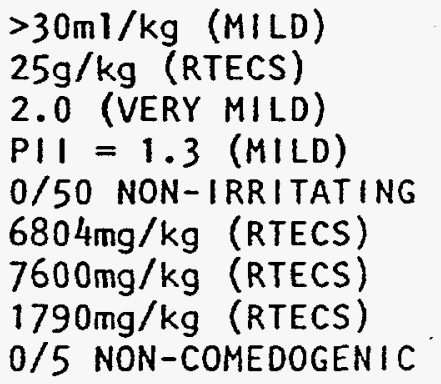

\section{REACTIVITY DATA}

Stability: Stable [X] Unstable [ ]

Incompatabilities: (Materials to Avoid) Strong oxidizing material can cause a reaction. Hazardous Decomposition Products: Thermal decomposition may produce carbon. mono/dioxides. Hazardous Polymerization: May Occur [ ] Will not occur [X]

Conditions to Avoid: See above statements.

\section{SPILL, LEAK AND DISPOSAL PROCEDURES}

Action to take for spills: (Use appropriate Safety Equipment) Use absorbent material to collect and contain for disposal. Contain large spills and pump into a suitable tank. Wash area with suitable detergent and thoroughly rinse.

Disposal Method: All Local, State and Federal Regulations concerning health and pollution should be reviewed to determine approved disposal procedures. 


\section{SPECIAL HANDLING INFORMATION}

Ventilation:

1. Local Exhaust: None should be needed

2. Mechanical (general): Recommended

3. Respiratory Protection (type): None should be needed (for emergency, use a canister for organic vapors such as GMA from Mine Safety Appliance Co.)

Protective Clothing: Clean, body-covering clothing. In addition, rubber gloves, boots, and apron, depending upon the exposure likely, or as required by your company. Eye Protection: Chemical Workers Goggles recommended.

Other Protective Equipment: Eye Fountain and Safety Shower in work area.

\section{PRECAUTIONS TO BE TAKEN IN HANDLING AND STORAGE}

Store in well ventilated areas at temperatures below $120^{\circ} \mathrm{F}$.

last revised 20 OCT $1993 \mathrm{MJC} / \mathrm{TBH}$ Compliance Department 
Appendix B

\author{
Injection Data \\ (Rates and Heads)
}


Paducah Gaseous Diffusion Plant Paducah, Kentucky

DNAPL Solubilization Test - Well MW-156, SE Corner of Building C-400 Injection Phase Data - August 5-9,1994

\begin{tabular}{|c|c|c|c|c|c|c|}
\hline Time & Minutes & Solinst & Hours & Ground Water & Totalizer & Average \\
\hline & Between Readings & TOC DTW & into Test & Elevation & Total Gallons & Injection Rate \\
\hline & & (feet) & & (feet msl) & Pumped & (gallons/minute) \\
\hline & & & & & & \\
\hline 06:30 PM & & 50.91 & 0.00 & 331.15 & 1174 & 1.00 \\
\hline 09:07 PM & 157 & 50.95 & 2.62 & 331.11 & 1336 & 1.03 \\
\hline $11: 17 \mathrm{PM}$ & 130 & 50.95 & 4.78 & 331.11 & 1463.5 & 0.98 \\
\hline 12:17 AM & 60 & 50.92 & 5.78 & 331.14 & 1529 & 1.09 \\
\hline 01:00 AM & 43 & 50.89 & 6.50 & 331.17 & 1556.4 & 0.64 \\
\hline 01:22 PM & 742 & 50.6 & 18.87 & 331.46 & 2299 & 1.00 \\
\hline 03:07 PM & 105 & 50.5 & 20.62 & 331.56 & 2402.62 & 0.99 \\
\hline 06:00 PM & 173 & 50.39 & 23.50 & 331.67 & 2573 & 0.98 \\
\hline 06:30 PM & 30 & 50.39 & 24.00 & 331.67 & 2602.5 & 0.98 \\
\hline 08:30 PM & 120 & 50.34 & 26.00 & 331.72 & 2720.2 & 0.98 \\
\hline 10:30 PM & 120 & 50.32 & 28.00 & 331.74 & 2837.8 & 0.98 \\
\hline 01:30 AM & 180 & 50.21 & 31.00 & 331.85 & 3014.2 & 0.98 \\
\hline 02:30 AM & 60 & 50.18 & 32.00 & 331.88 & 3072.8 & 0.98 \\
\hline 03:30 AM & 60 & 50.16 & 33.00 & 331.9 & 3131.3 & 0.97 \\
\hline 04:30 AM & 60 & 50.13 & 34.00 & 331.93 & 3189.2 & 0.96 \\
\hline 05:30 AM & 60 & 50.1 & 35.00 & 331.96 & 3246.9 & 0.96 \\
\hline 06:30 AM & 60 & 50.16 & 36.00 & 331.9 & 3309 & 1.03 \\
\hline 07:30 AM & 60 & 50.08 & 37.00 & 331.98 & 3367.6 & 0.98 \\
\hline $08: 30$ AM & 60 & 50.03 & 38.00 & 332.03 & 3425.7 & 0.97 \\
\hline 09:30 AM & 60 & 49.98 & 39.00 & 332.08 & 3483.4 & 0.96 \\
\hline 12:00 PM & 150 & 49.9 & 41.50 & 332.16 & 3630.3 & 0.98 \\
\hline $05: 00 \mathrm{PM}$ & 300 & 49.55 & 46.50 & 332.51 & 3926.8 & 0.99 \\
\hline 06:00 PM & 60 & 49.5 & 47.50 & 332.56 & 3985.7 & 0.98 \\
\hline 07:00 PM & 60 & 49.43 & 48.50 & 332.63 & 4043.4 & 0.96 \\
\hline 08:00 PM & 60 & 49.4 & 49.50 & 332.66 & 4103.7 & 1.00 \\
\hline 09:00 PM & 60 & 49.37 & 50.50 & 332.69 & 4160.9 & 0.95 \\
\hline 10:00 PM & 60 & 49.35 & 51.50 & 332.71 & 4219.6 & 0.98 \\
\hline 11:00 PM & 60 & 49.35 & 52.50 & 332.71 & 4279.3 & 0.99 \\
\hline 12:00 AM & 60 & 49.32 & 53.50 & 332.74 & 4338.8 & 0.99 \\
\hline 01:00 AM & 60 & 49.29 & 54.50 & 332.77 & 4398.3 & 0.99 \\
\hline $02: 00 \mathrm{AM}$ & 60 & 49.24 & 55.50 & 332.82 & 4458.1 & 1.00 \\
\hline 03:00 AM & 60 & 49.22 & 56.50 & 332.84 & 4517.6 & 0.99 \\
\hline 04:00 AM & 60 & 49.18 & 57.50 & 332.88 & 4577.2 & 0.99 \\
\hline 05:00 AM & 60 & 49.16 & 58.50 & 332.9 & 4636.6 & 0.99 \\
\hline 06:00 AM & 60 & 49.14 & 59.50 & 332.92 & 4695.9 & 0.99 \\
\hline $07: 00 \mathrm{AM}$ & 60 & 49.13 & 60.50 & 332.93 & 4755.2 & 0.99 \\
\hline 08:00 AM & 60 & 49.11 & 61.50 & 332.95 & 4814.5 & 0.99 \\
\hline 09:00 AM & 60 & 49.1 & 62.50 & 332.96 & 4873.8 & 0.99 \\
\hline $10: 00 \mathrm{AM}$ & 60 & 49.06 & 63.50 & 333 & 4933.1 & 0.99 \\
\hline 11:03 AM & 63 & 49.02 & 64.55 & 333.04 & 4995.2 & 0.99 \\
\hline 12:00 PM & 57 & 48.95 & 65.50 & 333.11 & 5051.5 & 0.99 \\
\hline 01:30 PM & 90 & 48.8 & 67.00 & 333.26 & 5139.5 & 0.98 \\
\hline 02:30 PM & 60 & 48.7 & 68.00 & 333.36 & 5199 & 0.99 \\
\hline 04:00 PM & 90 & 48.52 & 69.50 & 333.54 & 5290.2 & 1.01 \\
\hline 05:20 PM & 80 & 48.33 & 70.83 & 333.73 & 5373.1 & 1.04 \\
\hline 06:00 PM & 40 & 48.26 & 71.50 & 333.8 & 5414.4 & 1.03 \\
\hline
\end{tabular}




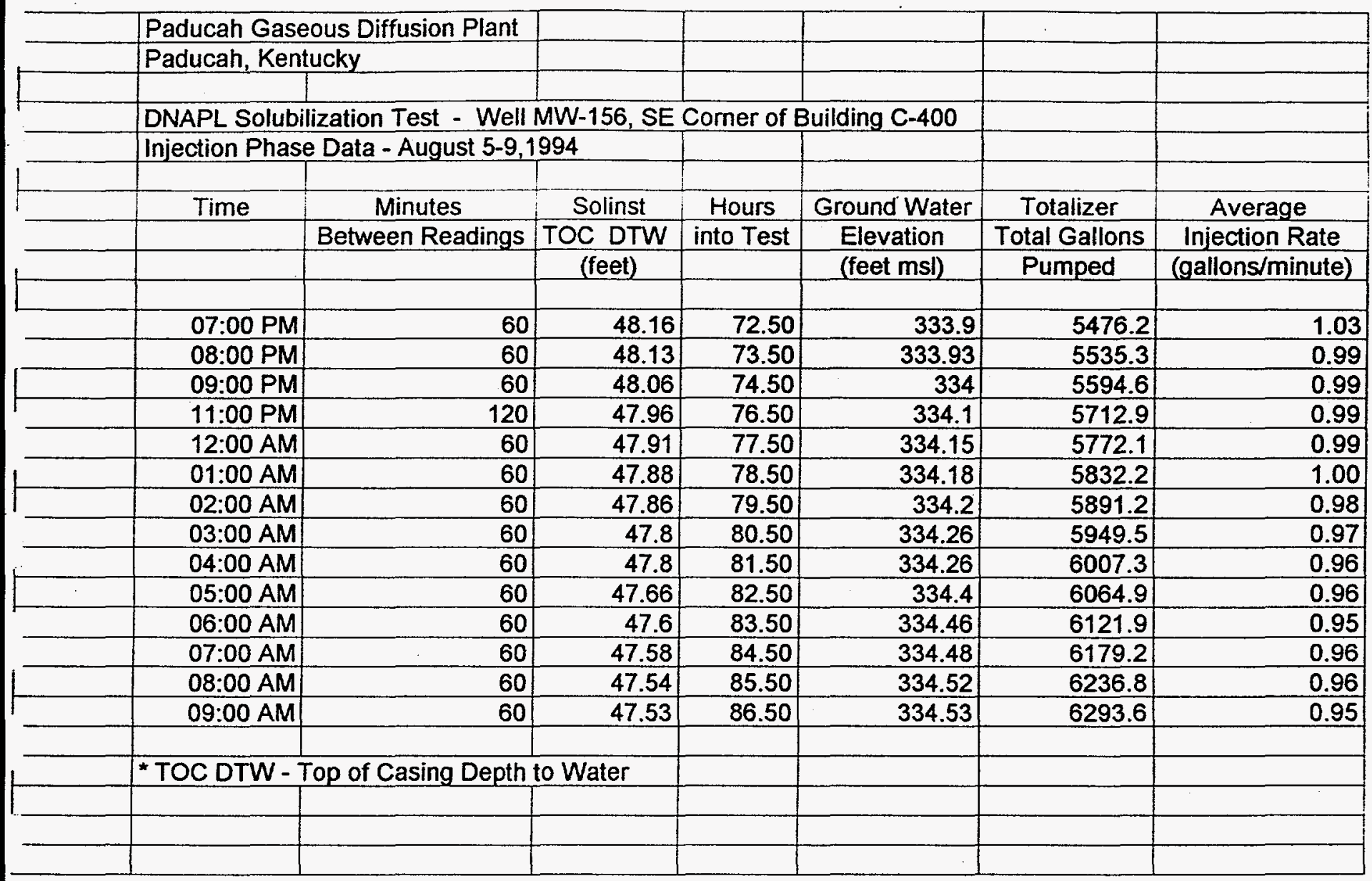


Paducah Gaseous Diffusion Plant DNAPL Solubilization Test

Water Level in Control Piezometer 109

During the Injection Phase

August 5-9, 1994

Date

Time

Ground Water

Elevation

(feet, msl)

05-Aug-94

05-Aug-94

05-Aug-94

05-Aug-94

05-Aug-94

05-Aug-94

05-Aug-94

05-Aug-94

05-Aug-94

05-Aug-94

05-Aug-94

05-Aug-94

05-Aug-94

05-Aug-94

05-Aug-94

05-Aug-94

05-Aug-94

05-Aug-94

05-Aug-94

05-Aug-94

05-Aug-94

05-Aug-94

05-Aug-94

05-Aug-94

06-Aug-94

06-Aug-94

06-Aug-94

06-Aug-94

06-Aug-94

06-Aug-94

06-Aug-94

06-Aug-94

06-Aug-94

06-Aug-94

06-Aug-94

06-Aug-94

06-Aug-94

06-Aug-94

06-Aug-94

06-Aug-94

06-Aug-94

06-Aug-94

06-Aug-94

$\begin{array}{lr}\text { 12:00 AM } & 331.974 \\ \text { 01:00 AM } & 331.974 \\ \text { 02:00 AM } & 331.968 \\ \text { 03:00 AM } & 331.945 \\ \text { 04:00 AM } & 331.928 \\ \text { 05:00 AM } & 331.889 \\ \text { 06:00 AM } & 331.861 \\ \text { 07:00 AM } & 331.833 \\ \text { 08:00 AM } & 331.816 \\ \text { 09:00 AM } & 331.799 \\ \text { 10:00 AM } & 331.793 \\ \text { 11:00 AM } & 331.788 \\ \text { 12:00 PM } & 331.793 \\ \text { 01:00 PM } & 331.799 \\ \text { 02:00 PM } & 331.805 \\ \text { 03:00 PM } & 331.816 \\ \text { 04:00 PM } & 331.827 \\ \text { 05:00 PM } & 331.827 \\ \text { 06:00 PM } & 331.816 \\ \text { 07:00 PM } & 331.799 \\ \text { 08:00 PM } & 331.776 \\ \text { 09:00 PM } & 331.765 \\ \text { 10:00 PM } & 331.76 \\ \text { 11:00 PM } & 331.748 \\ \text { 12:00 PM } & 331.76 \\ \text { 01:00 AM } & 331.782 \\ \text { 02:00 AM } & 331.765 \\ \text { 03:00 AM } & 331.76 \\ \text { 04:00 AM } & 331.76 \\ \text { 05:00 AM } & 331.76 \\ \text { 06:00 AM } & 331.76 \\ \text { 07:00 AM } & 331.743 \\ 08: 00 \text { AM } & 331.714 \\ \text { 09:00 AM } & 331.737 \\ \text { 10:00 AM } & 331.748 \\ \text { 11:00 AM } & 331.754 \\ \text { 12:00 PM } & 331.765 \\ \text { 01:00 PM } & 331.805 \\ \text { 02:00 PM } & 331.816 \\ 03: 00 \text { PM } & 331.827 \\ 04: 00 \text { PM } & 331.838 \\ \text { 05:00 PM } & 331.85 \\ \text { 06:00 PM } & 331.844\end{array}$


Date Time Ground Water

Elevation

(feet, msl)

\begin{tabular}{|c|c|c|}
\hline 06-Aug-94 & 02:00 PM & 331.816 \\
\hline 06-Aug-94 & 03:00 PM & 331.827 \\
\hline 06-Aug-94 & 04:00 PM & 331.838 \\
\hline 06-Aug-94 & 05:00 PM & 331.85 \\
\hline 06-Aug-94 & 06:00 PM & 331.844 \\
\hline 06-Aug-94 & 07:00 PM & 331.833 \\
\hline 06-Aug-94 & 08:00 PM & 331.816 \\
\hline 06-Aug-94 & 09:00 PM & 331.793 \\
\hline 06-Aug-94 & 10:00 PM & 331.799 \\
\hline 06-Aug-94 & 11:00 PM & 331.799 \\
\hline 07-Aug-94 & $12: 00 \mathrm{AM}$ & 331.788 \\
\hline 07-Aug-94 & 01:00 AM & 331.793 \\
\hline 07-Aug-94 & 02:00 AM & 331.799 \\
\hline 07-Aug-94 & 03:00 AM & 331.799 \\
\hline 07-Aug-94 & 04:00 AM & 331.805 \\
\hline 07-Aug-94 & 05:00 AM & 331.788 \\
\hline 07-Aug-94 & 06:00 AM & 331.771 \\
\hline 07-Aug-94 & 07:00 AM & 331.748 \\
\hline 07-Aug-94 & 08:00 AM & 331.76 \\
\hline 07-Aug-94 & 09:00 AM & 331.748 \\
\hline 07-Aug-94 & 10:00 AM & 331.754 \\
\hline 07-Aug-94 & 11:00 AM & 331.754 \\
\hline 07-Aug-94 & 12:00 PM & 331.788 \\
\hline 07-Aug-94 & 01:00 PM & 331.788 \\
\hline 07-Aug-94 & 02:00 PM & 331.816 \\
\hline 07-Aug-94 & 03:00 PM & 331.821 \\
\hline 07-Aug-94 & 04:00 PM & 331.816 \\
\hline 07-Aug-94 & 05:00 PM & 331.833 \\
\hline 07-Aug-94 & 06:00 PM & 331.821 \\
\hline 07-Aug-94 & 07:00 PM & 331.81 \\
\hline 07-Aug-94 & 08:00 PM & 331.793 \\
\hline 07-Aug-94 & 09:00 PM & 331.765 \\
\hline 07-Aug-94 & 10:00 PM & 331.76 \\
\hline 07-Aug-94 & $11: 00$ PM & 331.76 \\
\hline 08-Aug-94 & $12: 00$ PM & 331.754 \\
\hline 08-Aug-94 & 01:00 AM & 331.743 \\
\hline 08-Aug-94 & $02: 00 \mathrm{AM}$ & 331.743 \\
\hline 08-Aug-94 & 03:00 AM & 331.748 \\
\hline 08-Aug-94 & 04:00 AM & 331.726 \\
\hline 08-Aug-94 & 05:00 AM & 331.692 \\
\hline 08-Aug-94 & 06:00 AM & 331.692 \\
\hline 08-Aug-94 & 07:00 AM & 331.681 \\
\hline 08-Aug-94 & 08:00 AM & 331.658 \\
\hline 08-Aug-94 & 09:00 AM & 331.647 \\
\hline 08-Aug-94 & $10: 00 \mathrm{AM}$ & 331.63 \\
\hline 08-Aug-94 & 11:00 AM & 331.647 \\
\hline 08-Aug-94 & 12:00 PM & 331.664 \\
\hline 08-Aug-94 & 01:00 PM & 331.675 \\
\hline 08-Aug-94 & 02:00 PM & 331.692 \\
\hline 08-Aug-94 & 03:00 PM & 331.692 \\
\hline 08-Aug-94 & 04:00 PM & 331.709 \\
\hline
\end{tabular}




\begin{tabular}{|c|c|c|}
\hline Date & Time & $\begin{array}{c}\text { Ground Water } \\
\text { Elevation } \\
\text { (feet, msl) }\end{array}$ \\
\hline 08-Aug-94 & 05:00 PM & 331.72 \\
\hline 08-Aug-94 & 06:00 PM & 331.692 \\
\hline 08-Aug-94 & 0.7:00 PM & 331.669 \\
\hline 08-Aug-94 & 08:00 PM & 331.647 \\
\hline 08-Aug-94 & 09:00 PM & 331.63 \\
\hline 08-Aug-94 & 10:00 PM & 331.63 \\
\hline 08-Aug-94 & 11:00 PM & 331.624 \\
\hline 09-Aug-94 & 12:00 PM & 331.607 \\
\hline 09-Aug-94 & 01:00 AM & 331.529 \\
\hline 09-Aug-94 & 02:00 AM & 331.591 \\
\hline 09-Aug-94 & 03:00 AM & 331.591 \\
\hline 09-Aug-94 & 04:00 AM & 331.619 \\
\hline 09-Aug-94 & 05:00 AM & 331.591 \\
\hline 09-Aug-94 & 06:00 AM & 331.591 \\
\hline 09-Aug-94 & 07:00 AM & 331.551 \\
\hline 09-Aug-94 & $08: 00 \mathrm{AM}$ & 331.529 \\
\hline 09-Aug-94 & $09: 00 \mathrm{AM}$ & 331.512 \\
\hline 09-Aug-94 & $10: 00 \mathrm{AM}$ & 331.5 \\
\hline 09-Aug-94 & $11: 00 \mathrm{AM}$ & 331.495 \\
\hline 09-Aug-94 & 12:00 PM & 331.5 \\
\hline 09-Aug-94 & 01:00 PM & 331.529 \\
\hline 09-Aug-94 & 02:00 PM & 331.54 \\
\hline 09-Aug-94 & 03:00 PM & 331.54 \\
\hline 09-Aug-94 & 04:00 PM & 331.557 \\
\hline 09-Aug-94 & 05:00 PM & 331.557 \\
\hline 09-Aug-94 & 06:00 PM & 331.545 \\
\hline 09-Aug-94 & 07:00 PM & 331.523 \\
\hline 09-Aug-94 & 08:00 PM & 331.495 \\
\hline 09-Aug-94 & 09:00 PM & 331.489 \\
\hline 09-Aug-94 & 10:00 PM & 331.489 \\
\hline 09-Aug-94 & $11: 00 \mathrm{PM}$ & 331.489 \\
\hline
\end{tabular}


Appendix C

Extraction Data

(Rates and Heads) 


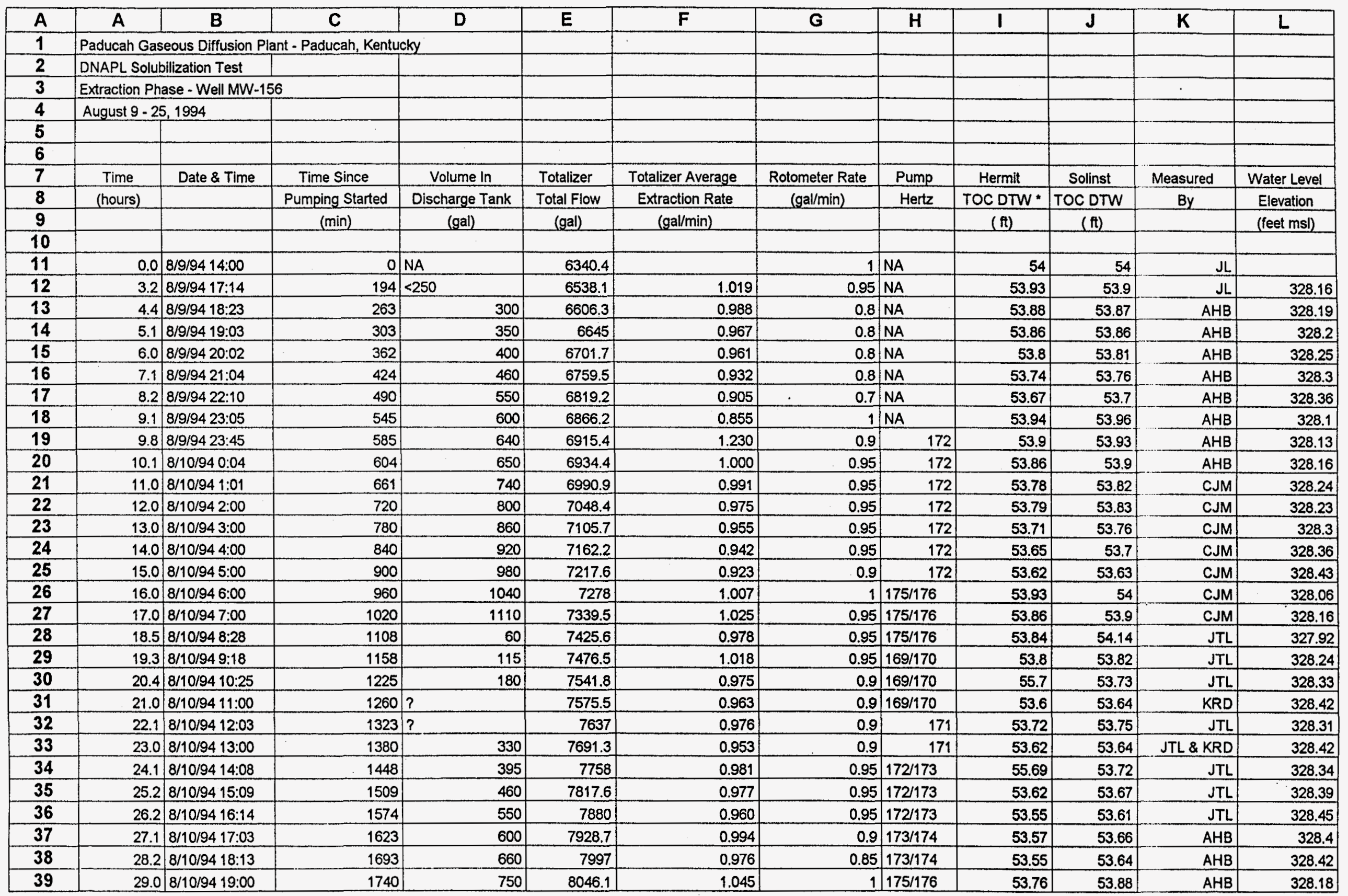




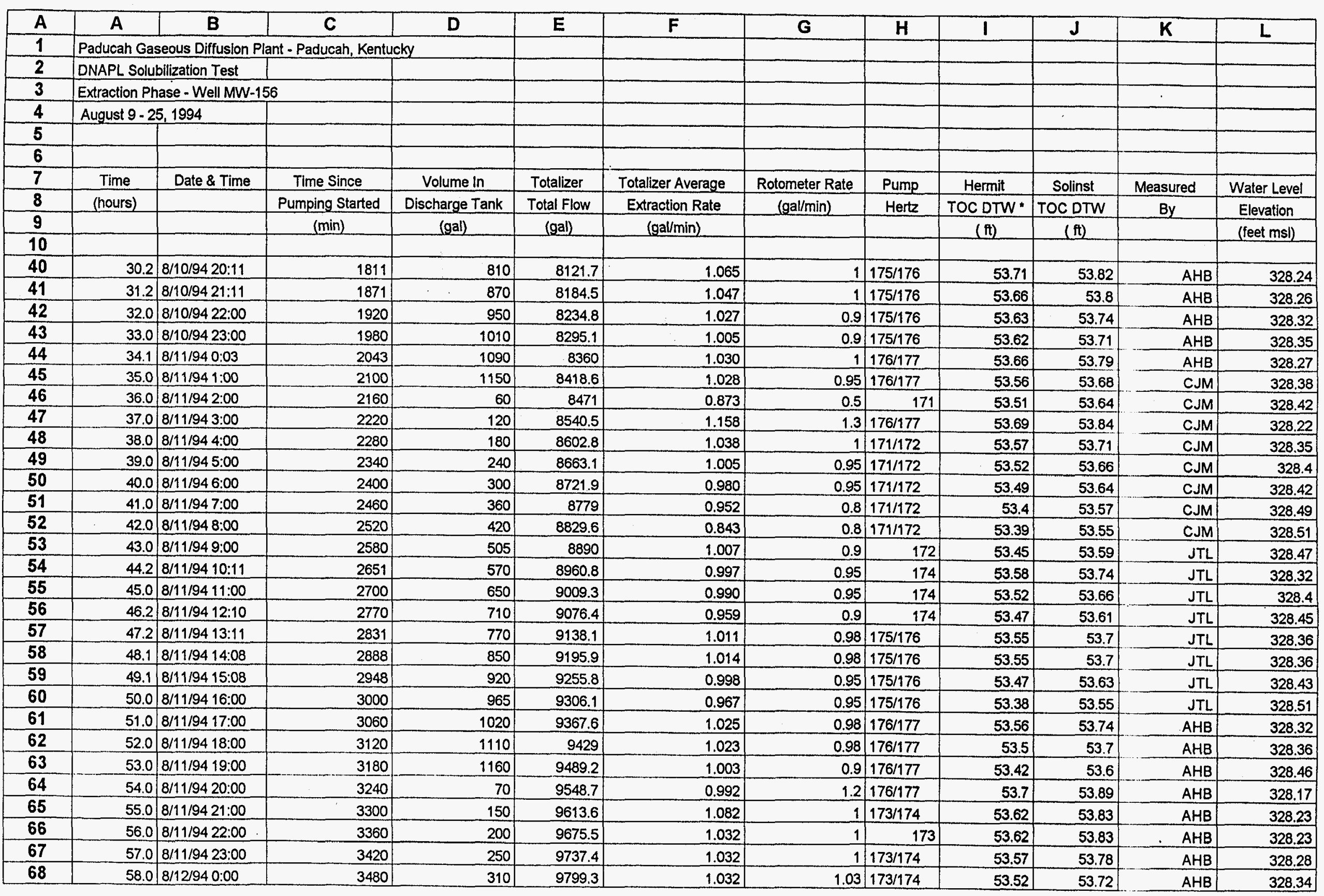




\begin{tabular}{|c|c|c|c|c|c|c|c|c|c|c|c|c|}
\hline A & A & $\mathbf{B}$ & $\mathbf{C}$ & D & $\mathbf{E}$ & $\mathbf{F}$ & $\mathbf{G}$ & $\mathrm{H}$ & 1 & $\mathbf{J}$ & $\mathrm{K}$ & $\mathbf{L}$ \\
\hline 1 & \multicolumn{4}{|c|}{ Paducah Gaseous Diffusion Plant - Paducah, Kentucky } & & & & & & & & \\
\hline 2 & \multirow{2}{*}{\multicolumn{3}{|c|}{ Extraction Phase - Well MW-156 }} & & & & & & & & & \\
\hline 3 & & & & & & & & & & & $\cdot$ & \\
\hline 4 & \multicolumn{2}{|c|}{ August $9-25,1994$} & & & & & & & & & & \\
\hline 5 & & & & & & & & & & & & \\
\hline 6 & & & & & & & & & & & & \\
\hline 7 & Time & Date \& Time & Time Since & Volume in & Totalizer & Totalizer Average & Rotometer Rate & Pump & Hermit & Solinst & Measured & Water Level \\
\hline 8 & (hours) & & Pumping Started & Discharge Tank & Total Flow & Extraction Rate & (gal/min) & Hertz & TOC DTW * & TOCDTW & By & Elevation \\
\hline 9 & & & (min) & (gal) & (gal) & (gal/min) & & & (ft) & $(\mathrm{ft})$ & & (feet msl) \\
\hline 10 & & & & & & & & & & & & \\
\hline 69 & 59.0 & $8 / 12 / 941: 00$ & 3540 & 380 & 9858 & 0.978 & 0.95 & $173 / 174$ & 53.48 & 53.68 & CJM & 328.38 \\
\hline 70 & 60.0 & 8/12/942:00 & 3600 & 440 & 9915.4 & 0.957 & 0.9 & 173 & 53.38 & 53.58 & CJM & 328.48 \\
\hline 71 & 61.0 & $8 / 12 / 943: 00$ & 3660 & 500 & 9971.6 & 0.937 & 0.9 & 173 & 53.37 & 53.57 & $\mathrm{CJM}$ & 328.49 \\
\hline 72 & 62.0 & $8 / 12 / 944: 00$ & 3720 & 560 & 10030.3 & 0.978 & 0.95 & $174 / 175$ & 53.5 & 53.7 & CJM & 328.36 \\
\hline 73 & 63.0 & 8/12/945:00 & 3780 & 620 & 10089.2 & 0.982 & 0.95 & $174 / 175$ & 53.47 & 53.67 & CJM & 328.39 \\
\hline 74 & 64.0 & $8 / 12 / 946: 00$ & 3840 & 720 & 10147.1 & 0.965 & 0.95 & $174 / 175$ & 53.45 & 53.66 & C.JM & 328.4 \\
\hline 75 & 65.0 & $8 / 12 / 947: 00$ & 3900 & 785 & 10204 & 0.948 & 0.9 & $174 / 175$ & 53.37 & 53.6 & CJM & 328.46 \\
\hline 76 & 66.0 & 8/12/948:00 & 3960 & 850 & 10260.2 & 0.937 & 0.9 & $174 / 175$ & 53.39 & 53.59 & C.JM & 328.47 \\
\hline 77 & 67.2 & 8/12/949:10 & 4030 & 920 & 10322.3 & 0.887 & 0.9 & $174 / 175$ & 53.3 & 53.5 & $\mathrm{JTL}$ & 328.56 \\
\hline 78 & 68.2 & $8 / 12 / 9410: 11$ & 4091 & 990 & 10383.6 & 1.005 & 1 & $176 / 177$ & 53.56 & 53.25 & JTL & 328.81 \\
\hline 79 & 69.2 & 8/12/94 11:11 & 4151 & 1050 & 10442.5 & 0.982 & 0.98 & $176 / 177$ & 53.5 & 53.68 & JTL & 328.38 \\
\hline 80 & 70.0 & $8 / 12 / 9412: 00$ & 4200 & 1100 & 10490 & 0.969 & 0.95 & $176 / 177$ & 53.43 & 53.64 & JTL & 328.42 \\
\hline 81 & 71.0 & $8 / 12 / 9413: 00$ & 4260 & 1150 & 10546.7 & 0.945 & 0.95 & $176 / 177$ & 53.48 & 53.66 & JTL & 328.4 \\
\hline 82 & 72.0 & $8 / 12 / 9414: 00$ & 4320 & $<100$ & 10604.4 & 0.962 & 1.25 & $176 / 177$ & 53.9 & 54.2 & $\mathrm{JTL}$ & 327.86 \\
\hline 83 & 73.0 & $8 / 12 / 9415: 00$ & 4380 & 100 & 10661 & 0.943 & 0.75 & $169 / 170$ & 53.1 & 53.37 & $\mathrm{AHB}$ & 328.69 \\
\hline 84 & 74.0 & $8 / 12 / 9416: 00$ & 4440 & $>100$ & 10713.2 & 0.870 & 0.75 & 170 & 53.14 & 53.39 & AHB & 328.67 \\
\hline 85 & 75.0 & $8 / 12 / 9417: 00$ & 4500 & $>100$ & 10764.3 & 0.852 & 0.75 & $169 / 170$ & 53.09 & 53.32 & $\mathrm{AHB}$ & 328.74 \\
\hline 86 & 76.0 & $8 / 12 / 9418: 01$ & 4561 & 300 & 10813.6 & 0.808 & 0.7 & $169 / 170$ & 52.97 & 53.2 & $\mathrm{AHB}$ & 328.86 \\
\hline 87 & 77.0 & $8 / 12 / 9419: 00$ & 4620 & 360 & 10879.3 & 1.114 & 1.1 & $175 / 176$ & 53.67 & 53.95 & $\mathrm{AHB}$ & 328.11 \\
\hline 88 & 78.0 & $8 / 12 / 9420: 00$ & 4680 & 440 & 10946.1 & 1.113 & 1.1 & 176 & 53.63 & 53.9 & $\mathrm{AHB}$ & 328.16 \\
\hline 89 & 79.0 & $8 / 12 / 9421: 00$ & 4740 & 530 & 11011.5 & 1.090 & 1.1 & 176 & 53.58 & 53.86 & $\mathrm{AHB}$ & 328.2 \\
\hline 90 & 80.0 & $8 / 12 / 9422: 00$ & 4800 & 600 & 11075.3 & 1.063 & 1.1 & 176 & 53.55 & 53.83 & $\mathrm{AHB}$ & 328.23 \\
\hline 91 & 81.0 & $8 / 12 / 9423: 00$ & 4860 & $>600$ & 11136.9 & 1.027 & 1 & $175 / 176$ & 53.55 & 53.84 & $\mathrm{AHB}$ & 328.22 \\
\hline 92 & 82.0 & $8 / 13 / 940: 00$ & 4920 & 720 & 11198.2 & 1.022 & 1 & $175 / 176$ & 53.42 & 53.71 & KRD & 328.35 \\
\hline 93 & 83.0 & $8 / 13 / 941: 00$ & 4980 & 800 & 11258 & 0.997 & 1 & $175 / 176$ & 53.42 & 53.69 & KRD & 328.37 \\
\hline 94 & 84.0 & $8 / 13 / 942: 00$ & 5040 & 850 & 11317.2 & 0.987 & 1 & $175 / 176$ & 53.37 & 53.66 & KRD & 328.4 \\
\hline 95 & 85.0 & $8 / 13 / 943: 00$ & 5100 & 915 & 11375.1 & 0.965 & 0.95 & $175 / 176$ & 53.27 & 53.55 & $\mathrm{KRD}$ & 328.51 \\
\hline 96 & 86.0 & $8 / 13 / 944: 00$ & 5160 & 990 & 11431.2 & 0.935 & 0.95 & $175 / 176$ & 53.23 & 53.49 & KRD & 328.57 \\
\hline 97 & 87.0 & $8 / 13 / 945: 00$ & 5220 & 1030 & 11488.8 & 0.960 & 1 & $177 / 178$ & 53.36 & 53.64 & KRD & 328.42 \\
\hline
\end{tabular}




\begin{tabular}{|c|c|c|c|c|c|c|c|c|c|c|c|c|}
\hline A & A & $\mathbf{B}$ & C & D & $\mathbf{E}$ & $\mathbf{F}$ & $\mathbf{G}$ & $\mathrm{H}$ & $\vec{I}$ & $\mathbf{J}$ & $\mathbf{K}$ & $\mathbf{L}$ \\
\hline 1 & \multicolumn{4}{|c|}{ Paducah Gaseous Diffusion Plant - Paducah, Kentucky } & & & & & & & & \\
\hline 2 & \multicolumn{2}{|c|}{ DNAPL Solubilization Test } & & & & & & & & & & \\
\hline 3 & \multicolumn{3}{|c|}{ Extraction Phase - Well MW-156 } & & & & & & & & & \\
\hline 4 & \multicolumn{2}{|c|}{ August $9-25,1994$} & & & & & & & & & & \\
\hline 5 & & & & & & & & & & & & \\
\hline 6 & & & & & & & & & & & & \\
\hline 7 & Time & Date \& Time & Time Since & Volume In & Totalizer & Totalizer Average & Rotometer Rate & Pump & Hermit & Solinst & Measured & Water Level \\
\hline 8 & (hours) & & Pumping Started & Discharge Tank & Total Flow & Extraction Rate & (gal/min) & Hertz & TOC DTW & TOC DTW & By & Elevation \\
\hline 9 & & & $(\min )$ & (gal) & (gal) & (gal/min) & & & (ft) & (ft) & & (feet msi) \\
\hline 10 & & & & & & & & & & & & \\
\hline 98 & 88.0 & 8/13/946:00 & 5280 & 1105 & 11546.8 & 0.967 & 0.98 & 177 & 53.33 & 53.6 & KRD & 328.46 \\
\hline 99 & 89.2 & $8 / 13 / 947: 11$ & 5351 & 60 & 11614.1 & 0.948 & 1.15 & 177 & 53.75 & 54.06 & KRD & 328 \\
\hline 100 & 90.4 & $8 / 13 / 948: 25$ & 5425 & 130 & NA & 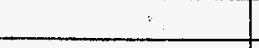 & 0.95 & NA & 53.26 & 53.56 & KRD & 328.5 \\
\hline 101 & 91.2 & 8/13/949:11 & 5471 & 180 & 11728.1 & & 0.9 & NA & 53.24 & 53.52 & KRD & 328.54 \\
\hline 102 & 92.1 & $8 / 13 / 9410: 07$ & 5527 & NA & 11783.1 & 0.982 & 1.05 & NA & 53.56 & 53.84 & PEM & 328.22 \\
\hline 103 & 93.2 & $8 / 13 / 9411: 12$ & 5592 & 300 & 11849.3 & 1.018 & 1 & NA & 53.39 & 53.7 & PEM & 328.36 \\
\hline 104 & 94.1 & $8 / 13 / 9412: 07$ & 5647 & 350 & 11902.9 & 0.975 & 1 & NA & 53.32 & 53.62 & PEM & 328.44 \\
\hline 105 & 95.1 & $8 / 13 / 9413: 03$ & 5703 & 410 & 11956.9 & 0.964 & 0.95 & $173 / 174$ & 53.24 & 53.55 & PEM & 328.51 \\
\hline 106 & 96.0 & $8 / 13 / 9414: 00$ & 5760 & 470 & 12010.6 & 0.942 & 0.95 & $173 / 174$ & 53.21 & 53.53 & $\mathrm{AHB}$ & 328.53 \\
\hline 107 & 97.0 & $8 / 13 / 9415: 00$ & 5820 & 540 & 12066 & 0.923 & 0.95 & $173 / 174$ & 53.14 & 53.46 & $\mathrm{AHB}$ & 328.6 \\
\hline 108 & 98.0 & $8 / 13 / 9416: 00$ & 5880 & 610 & 12123.5 & 0.958 & 1 & $175 / 176$ & 53.34 & 53.66 & $\mathrm{AHB}$ & 328.4 \\
\hline 109 & 99.0 & $8 / 13 / 9417: 00$ & 5940 & 670 & 12183.2 & 0.995 & 1 & $175 / 176$ & 53.3 & 53.61 & $\mathrm{AHB}$ & 328.45 \\
\hline 110 & 100.0 & $8 / 13 / 9418: 02$ & 6002 & 740 & 12248 & 1.045 & 1.15 & $178 / 179$ & 53.52 & 53.88 & $\mathrm{AHB}$ & 328.18 \\
\hline 111 & 101.0 & $8 / 13 / 9419: 01$ & 6061 & 820 & 12313.1 & 1.103 & 1.15 & $178 / 179$ & 53.48 & 53.81 & $\mathrm{AHB}$ & 328.25 \\
\hline 112 & 102.1 & $8 / 13 / 9420: 08$ & 6128 & 920 & 12386.1 & 1.090 & 1.15 & $178 / 179$ & 53.4 & 53.75 & $\mathrm{AHB}$ & 328.31 \\
\hline 113 & 103.0 & $8 / 13 / 9421: 02$ & 6182 & 960 & 12442.8 & 1.050 & 1.15 & $178 / 179$ & 53.36 & 53.7 & $\mathrm{AHB}$ & 328.36 \\
\hline 114 & 104.0 & 8/13/94 22:00 & 6240 & 1020 & 12502.5 & 1.029 & 1.15 & $178 / 179$ & 53.32 & 53.66 & $\mathrm{AHB}$ & 328.4 \\
\hline 115 & 105.0 & $8 / 13 / 9423: 00$ & 6300 & 1095 & 12563.8 & 1.022 & 1.05 & $178 / 179$ & 53.33 & 53.64 & KRD & 328.42 \\
\hline 116 & 106.0 & $8 / 14 / 940: 00$ & 6360 & 1145 & 12618.2 & 0.907 & 0.9 & $176 / 177$ & 52.98 & 53.29 & KRD & 328.77 \\
\hline 117 & 107.0 & $8 / 14 / 941: 00$ & 6420 & 75 & 12677.2 & 0.983 & 1.4 & $180 / 181$ & 53.88 & 53.23 & KRD & 328.83 \\
\hline 118 & 108.0 & $8 / 14 / 942: 00$ & 6480 & 140 & 12737.8 & 1.010 & 0.92 & 172 & 53.06 & 53.39 & KRD & 328.67 \\
\hline 119 & 109.0 & 8/14/94 3:00 & 6540 & 225 & 12798.1 & 1.005 & 1 & $174 / 175$ & 53.26 & 53.6 & KRD & 328.46 \\
\hline 120 & 110.2 & $8 / 14 / 944: 10$ & 6610 & 280 & 12867.8 & 0.996 & 1 & $174 / 175$ & 53.24 & 53.58 & KRD & 328.48 \\
\hline 121 & 111.0 & $8 / 14 / 945: 00$ & 6660 & 320 & 12917.8 & 1.000 & 1 & $174 / 175$ & 53.23 & 53.55 & KRD & 328.51 \\
\hline 122 & 112.0 & $8 / 14 / 946: 00$ & 6720 & 380 & 12975.6 & 0.963 & 0.95 & $174 / 175$ & 53.14 & 53.48 & KRD & 328.58 \\
\hline 123 & 113.0 & $8 / 14 / 947: 00$ & 6780 & 450 & 13035.9 & 1.005 & 1.05 & $176 / 177$ & 53.32 & 53.64 & KRD & 328.42 \\
\hline 124 & 114.0 & $8 / 14 / 948: 00$ & 6840 & 535 & 13096.2 & 1.005 & 1 & $176 / 177$ & 53.27 & 53.6 & KRD & 328.46 \\
\hline 125 & 115.0 & $8 / 14 / 949: 00$ & 6900 & NA & 13155.9 & 0.995 & 1 & $176 / 177$ & 53.28 & 53.6 & PEM & 328.46 \\
\hline 126 & 116.0 & $8 / 14 / 9410: 00$ & 6960 & 660 & 13215.7 & 0.997 & 1 & $176 / 177$ & 53.25 & 53.58 & PEM & 328.48 \\
\hline
\end{tabular}




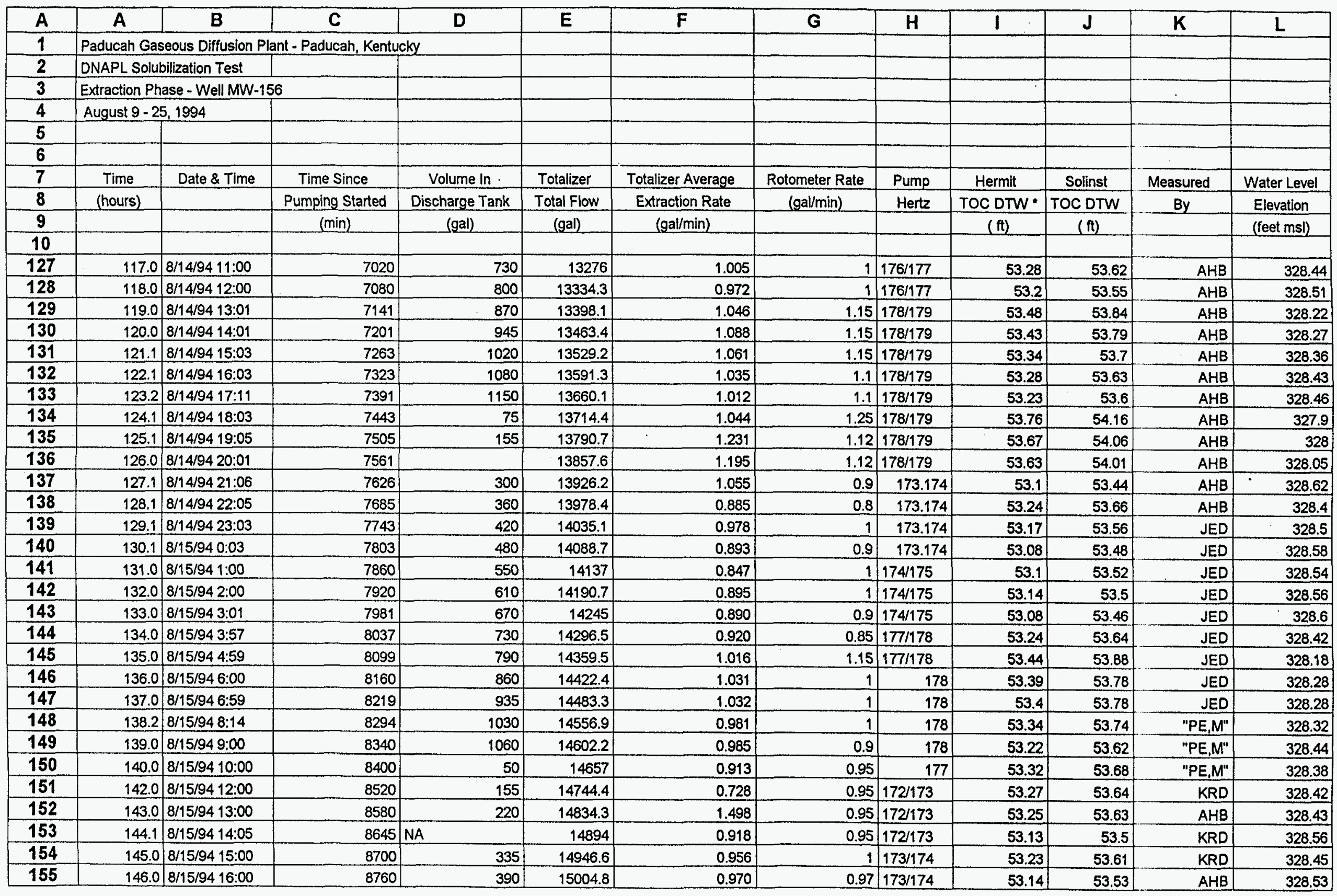




\begin{tabular}{|c|c|c|c|c|c|c|c|c|c|c|c|c|}
\hline $\bar{A}$ & A & $\mathbf{B}$ & C & D & $E$ & $\mathbf{F}$ & $\mathbf{G}$ & $\mathrm{H}$ & 1 & $\mathbf{J}$ & $\mathbf{K}$ & $L$ \\
\hline 1 & \multicolumn{4}{|c|}{ Paducah Gaseous Diffusion Plant - Paducah, Kentucky } & & & & & & & & \\
\hline 2 & \multicolumn{2}{|c|}{ DNAPL Solubilization Test } & & & & & & & & & & \\
\hline 3 & \multicolumn{3}{|c|}{ Extraction Phase - Well MW-156 } & & & & & & & & & \\
\hline 4 & \multicolumn{2}{|c|}{ August $9-25,1994$} & & & & & & & & & & \\
\hline 5 & & & & & & & & & & & & \\
\hline \multicolumn{10}{|l|}{6} & & & \\
\hline 7 & Time & Date \& Time & Time Since & Volume In & Totalizer & Totalizer Average & Rotometer Rate & Pump & Hermit & Solinst & Measured & Water Level \\
\hline 8 & (hours) & & Pumping Started & Discharge Tank & Total Flow & Extraction Rate & $(\mathrm{gal} / \mathrm{min})$ & Hertz & TOC DTW * & TOC DTW & By & Elevation \\
\hline 9 & & & $(\min )$ & (gal) & (gal) & (gal/min) & & & $(\mathrm{ft})$ & $(f)$ & & (feet msl) \\
\hline \multicolumn{13}{|l|}{10} \\
\hline 156 & 147.0 & $8 / 15 / 9417: 00$ & 8820 & 450 & 15061.8 & 0.950 & 0.98 & $173 / 174$ & 53.14 & 53.52 & $\mathrm{AHB}$ & 328.54 \\
\hline 157 & 148.0 & $8 / 15 / 9418: 00$ & 8880 & 530 & 15121.6 & 0.997 & 1.01 & $176 / 177$ & 53.36 & 53.75 & $\mathrm{AHB}$ & 328.31 \\
\hline 158 & 149.0 & $8 / 15 / 9419: 01$ & 8941 & 600 & 15185 & 1.039 & 1 & $176 / 177$ & 53.33 & 53.75 & $\mathrm{AHB}$ & 328.31 \\
\hline 159 & 150.1 & $8 / 15 / 9420: 05$ & 9005 & 700 & 15250.7 & 1.027 & 1 & $176 / 177$ & 53.29 & 53.69 & $\mathrm{AHB}$ & 328.37 \\
\hline 160 & 151.0 & $8 / 15 / 9421: 01$ & 9061 & 750 & 15306.5 & 0.996 & 1 & $176 / 177$ & 53.26 & 53.66 & $\mathrm{AHB}$ & 328.4 \\
\hline 161 & 152.0 & $8 / 15 / 9422: 00$ & 9120 & 800 & 15364.4 & 0.981 & 1 & $176 / 177$ & 53.27 & 53.68 & $\mathrm{AHB}$ & 328.38 \\
\hline 162 & 153.0 & 8/15/94 23:00 & 9180 & 880 & 15422.6 & 0.970 & 1 & $175 / 176$ & 53.22 & 53.64 & JED \& KRD & 328.42 \\
\hline 163 & 154.2 & $8 / 16 / 940: 10$ & 9250 & 940 & 15489.3 & 0.953 & 1 & $175 / 176$ & 53.16 & 53.55 & JED \& KRD & 328.51 \\
\hline 164 & 155.0 & $8 / 16 / 941: 02$ & 9302 & 1000 & 15534.5 & 0.869 & 0.95 & $175 / 176$ & 53.12 & 53.54 & JED \& RDS & 328.52 \\
\hline 165 & 156.1 & $8 / 16 / 942: 08$ & 9368 & 1070 & 15595.3 & 0.921 & 1 & $177 / 178$ & 53.22 & 53.65 & JED \& RDS & 328.41 \\
\hline 166 & 157.0 & $8 / 16 / 943: 00$ & 9420 & 1130 & 15648.2 & 1.017 & 1 & $177 / 178$ & 53.26 & 53.68 & JED \& RDS & 328.38 \\
\hline 167 & 158.0 & $8 / 16 / 944: 01$ & 9481 & 55 & 15708.4 & 0.987 & 1 & $177 / 178$ & 53.23 & 53.66 & JED \& RDS & 328.4 \\
\hline 168 & 159.0 & $8 / 16 / 944: 59$ & 9539 & 130 & 15776.7 & 1.178 & 1.5 & $171 / 172$ & 53.26 & 53.69 & JED \& RDS & 328.37 \\
\hline 169 & 160.0 & $8 / 16 / 945: 59$ & 9599 & 200 & 15835.1 & 0.973 & 1 & $171 / 172$ & 53.2 & 53.63 & JED \& RDS & 328.43 \\
\hline 170 & 161.0 & 8/16/94 7:00 & 9660 & 250 & 15893.5 & 0.957 & 1 & $172 / 173$ & 53.22 & 53.64 & JED \& RDS & 328.42 \\
\hline 171 & 162.3 & $8 / 16 / 948: 20$ & 9740 & 350 & 15972.9 & 0.992 & 0.95 & $172 / 173$ & 53.18 & 53.61 & KRD & 328.45 \\
\hline 172 & 163.0 & 8/16/949:00 & 9780 & 390 & 16013.4 & 1.013 & 1 & $174 / 175$ & 53.3 & 53.7 & $\mathrm{JTL}$ & 328.36 \\
\hline 173 & 164.0 & $8 / 16 / 9410: 00$ & 9840 & 450 & 16073.5 & 1.002 & 1 & $174 / 175$ & 53.25 & 53.67 & $\mathrm{JTL}$ & 328.39 \\
\hline 174 & 165.3 & $8 / 16 / 9411: 15$ & 9915 & 550 & 16147.6 & 0.988 & 1 & $174 / 175$ & 53.24 & 53.64 & $\mathrm{JTL}$ & 328.42 \\
\hline 175 & 166.0 & $8 / 16 / 9412: 00$ & 9960 & 600 & 16191.5 & 0.976 & 1 & 175 & 53.22 & 53.63 & KRD & 328.43 \\
\hline 176 & 167.2 & $8 / 16 / 9413: 10$ & 10030 & 700 & 16259.2 & 0.967 & 0.95 & 175 & 53.1 & 53.54 & JTL & 328.52 \\
\hline 177 & 168.0 & $8 / 16 / 9414: 00$ & 10080 & 730 & 16319.2 & 1.200 & 1 & 176 & 53.24 & 53.65 & JTL & 328.41 \\
\hline 178 & 169.0 & $8 / 16 / 9415: 00$ & 10140 & 790 & 16369 & 0.830 & 1 & 176 & 53.22 & 53.63 & JTL & 328.43 \\
\hline 179 & 170.1 & $8 / 16 / 9416: 05$ & 10205 & 855 & 16433.1 & 0.986 & 0.95 & 176 & 53.12 & 53.55 & $\mathrm{AHB}$ & 328.51 \\
\hline 180 & 171.3 & $8 / 16 / 9417: 20$ & 10280 & 950 & 16509.5 & 1.019 & 1 & $177 / 178$ & 53.25 & 53.7 & $\mathrm{AHB}$ & 328.36 \\
\hline 181 & 172.0 & $8 / 16 / 9418: 00$ & 10320 & 1000 & 16550.4 & 1.023 & 1 & $177 / 178$ & 53.22 & 53.66 & $\mathrm{AHB}$ & 328.4 \\
\hline 182 & 173.0 & $8 / 16 / 9419: 00$ & 10380 & 1060 & 16609.8 & 0.990 & 0.98 & $177 / 178$ & 53.1 & 53.54 & $\mathrm{AHB}$ & 328.52 \\
\hline 183 & 174.2 & $8 / 16 / 9420: 14$ & 10454 & NA & 16686 & 1.030 & 1.05 & $178 / 179$ & 53.31 & 53.76 & $\mathrm{AHB}$ & 328.3 \\
\hline 184 & 175.0 & $8 / 16 / 9421: 00$ & 10500 & 1150 & 16735.9 & 1.085 & 1.1 & 179 & 53.38 & 53.84 & $\mathrm{AHB}$ & 328.22 \\
\hline
\end{tabular}




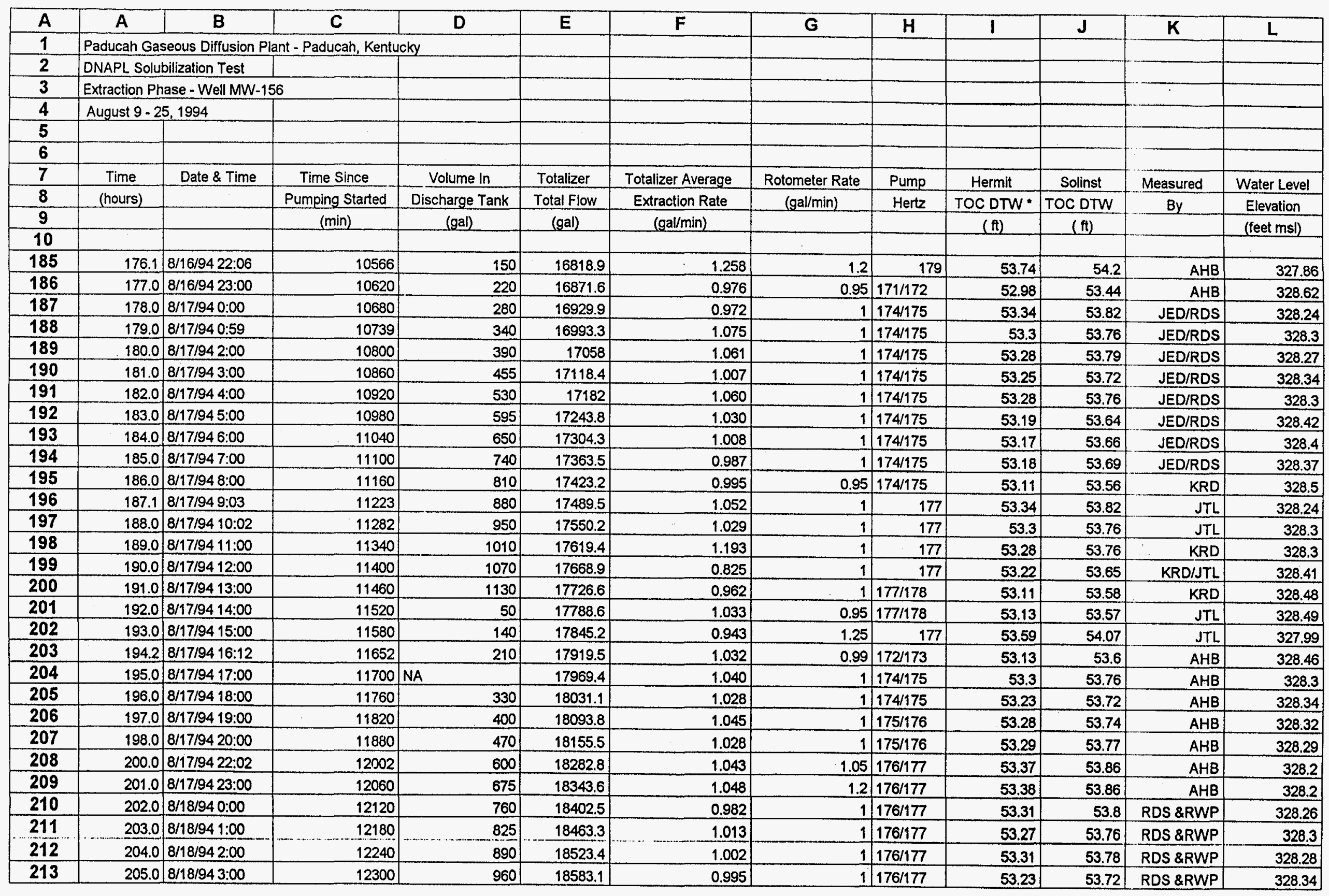




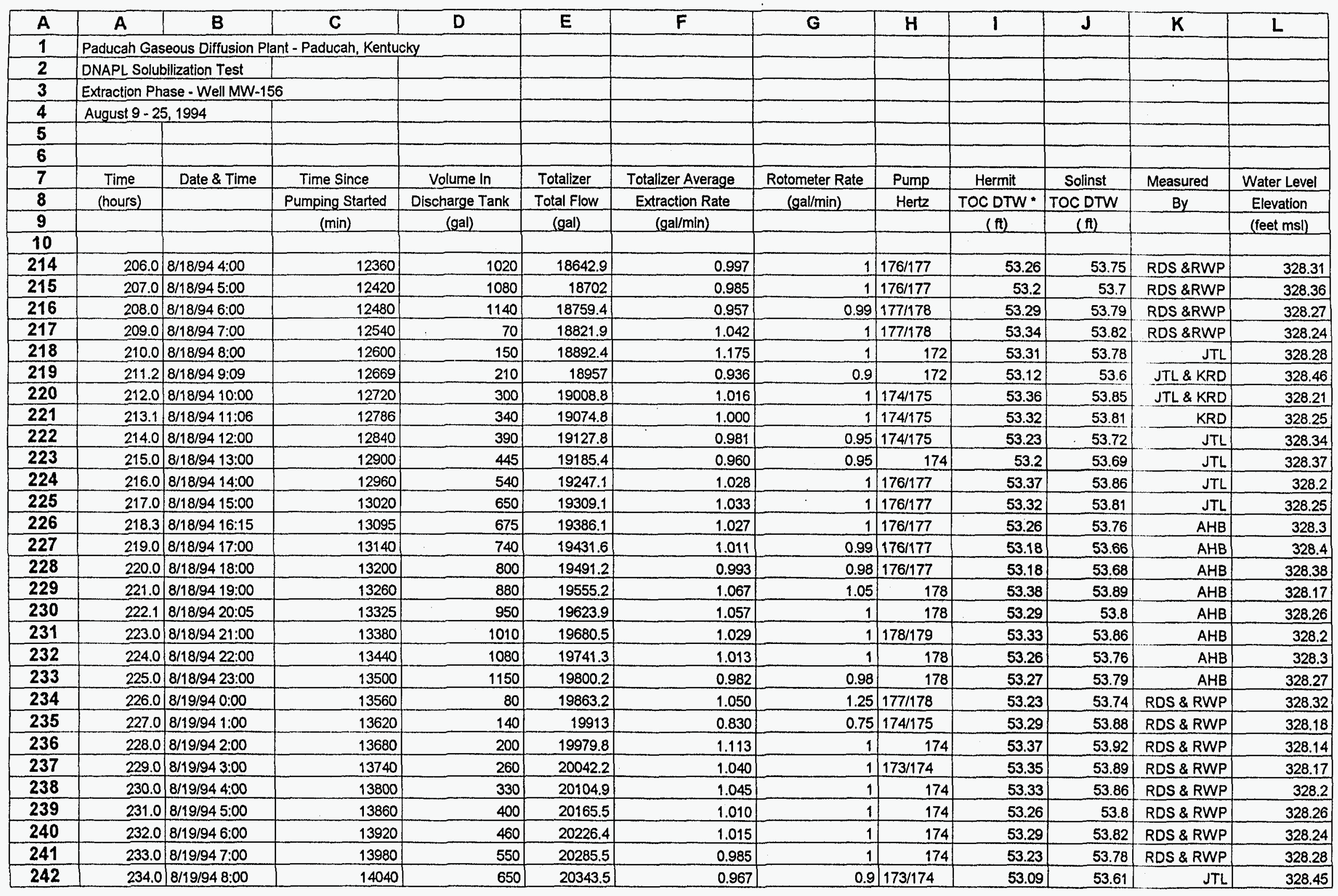




\begin{tabular}{|c|c|c|c|c|c|c|c|c|c|c|c|c|}
\hline $\mathbf{A}$ & A & B & C & D & $\mathbf{E}$ & $\mathbf{F}$ & $\mathbf{G}$ & $\mathrm{H}$ & 1 & $J$ & $\mathbf{K}$ & $\mathbf{L}$ \\
\hline 1 & \multicolumn{4}{|c|}{ Paducah Gaseous Diffusion Plant - Paducah, Kentucky } & & & & & & & & \\
\hline 2 & \multicolumn{2}{|c|}{ DNAPL Solubilization Test } & & & & & & & & & & \\
\hline 3 & \multicolumn{3}{|c|}{ Extraction Phase - Well MW-156 } & & & & & & & & . & \\
\hline 4 & \multicolumn{2}{|c|}{ August $9-25,1994$} & & & & & & & & & & \\
\hline 5 & & & & & & & & & & & & \\
\hline 6 & & & & & & & & & & & & \\
\hline 7 & Time & Date \& Time & Time Since & Volume in & Totalizer & Totalizer Average & Rotometer Rate & Pump & Hermit & Solinst & Measured & Water Level \\
\hline 8 & (hours) & & Pumping Started & Discharge Tank & Total Flow & Extraction Rate & (gal/min) & Hertz & TOC DTW & TOC DTW & By & Elevation \\
\hline 9 & & & $(\min )$ & (gal) & (gal) & (gal/min) & & & (ft) & (ft) & & (feet msl) \\
\hline 10 & & & & & & & & & & & & \\
\hline 243 & 235.0 & $8 / 19 / 949: 00$ & 14100 & 670 & 20402.6 & 0.985 & 0.98 & 175 & 53.26 & 53.77 & JTL & 328.29 \\
\hline 244 & 236.0 & $8 / 19 / 9410: 00$ & 14160 & 745 & 20462.2 & 0.993 & 0.98 & $176 / 177$ & 53.28 & 53.82 & KRD & 328.24 \\
\hline 245 & 237.0 & $8 / 19 / 9411: 00$ & 14220 & 805 & 20520.8 & 0.977 & 1 & $176 / 177$ & 53.26 & 53.8 & KRD & 328.26 \\
\hline 246 & 238.0 & $8 / 19 / 9412: 00$ & 14280 & 880 & 20581.1 & 1.005 & 1 & $177 / 178$ & 53.38 & 53.92 & $\mathrm{JTL}$ & 328.14 \\
\hline 247 & 239.0 & $8 / 19 / 9413: 00$ & 14340 & 950 & 20643.5 & 1.040 & 1 & $177 / 178$ & 53.32 & 53.86 & JTL & 328.2 \\
\hline 248 & 240.0 & $8 / 19 / 9414: 00$ & 14400 & 1010 & 20705 & 1.025 & 1 & 178 & 53.27 & 53.91 & JTL & 328.15 \\
\hline 249 & 241.0 & $8 / 19 / 9415: 00$ & 14460 & NA & 20766.6 & 1.027 & 1.25 & 178 & 53.7 & 54.26 & JTL & 327.8 \\
\hline 250 & 242.0 & $8 / 19 / 9416: 00$ & 14520 & 175 & 20832.6 & 1.100 & 0.98 & 173 & 53.7 & 53.15 & $\mathrm{AHB}$ & 328.91 \\
\hline 251 & 243.1 & $8 / 19 / 9417: 03$ & 14583 & $N A$ & 20894.2 & 0.978 & 0.95 & $172 / 173$ & 53.06 & 53.6 & $\mathrm{AHB}$ & 328.46 \\
\hline 252 & 244.5 & $8 / 19 / 9418: 31$ & 14671 & NA & 20991.2 & 1.102 & 1.01 & $175 / 176$ & 53.31 & 53.86 & $\mathrm{AHB}$ & 328.2 \\
\hline 253 & 245.0 & $8 / 19 / 9419: 00$ & 14700 & 350 & 21019.8 & 0.986 & 1.01 & $175 / 176$ & 53.28 & 53.84 & $\mathrm{AHB}$ & 328.22 \\
\hline 254 & 246.2 & $8 / 19 / 9420: 10$ & 14770 & 430 & 21093.3 & 1.050 & 1 & $175 / 176$ & 53.23 & 53.8 & $\mathrm{AHB}$ & 328.26 \\
\hline 255 & 247.0 & $8 / 19 / 9421: 00$ & 14820 & 500 & 21144.8 & 1.030 & 1 & $175 / 176$ & 53.23 & 53.8 & $\mathrm{AHB}$ & 328.26 \\
\hline 256 & 248.0 & $8 / 19 / 9422: 00$ & 14880 & 570 & 21205.2 & 1.007 & 1 & $175 / 176$ & 53.16 & 53.73 & AHB & 328.33 \\
\hline 257 & 249.0 & $8 / 19 / 9423: 00$ & 14940 & NA & 21265.2 & 1.000 & 1 & $175 / 176$ & 53.14 & 53.7 & AHB & 328.36 \\
\hline 258 & 250.0 & $8 / 20 / 940: 00$ & 15000 & 700 & 21323.5 & 0.972 & 1 & $177 / 178$ & 53.28 & 53.9 & JWD & 328.16 \\
\hline 259 & 251.0 & $8 / 20 / 941: 00$ & 15060 & 752 & 21389 & 1.092 & 1.01 & $177 / 178$ & 53.3 & 53.95 & EFJ & 328.11 \\
\hline 260 & 252.0 & $8 / 20 / 942: 00$ & 15120 & 840 & 21453.6 & 1.077 & 1 & 178 & 53.3 & 53.91 & $E F J$ & 328.15 \\
\hline 261 & 253.0 & $8 / 20 / 943: 00$ & 15180 & 915 & 21517.5 & 1.065 & 1 & $176 / 178$ & 53.3 & 53.92 & EFJ \& JWD & 328.14 \\
\hline 262 & 254.0 & $8 / 20 / 944: 00$ & 15240 & 970 & 21574.8 & 0.955 & 0.98 & 176 & 53.02 & 53.93 & EFJ \& JWD & 328.13 \\
\hline 263 & 255.0 & 8/20/945:00 & 15300 & 1030 & 21635.5 & 1.012 & 1 & $177 / 178$ & 53.13 & 53.77 & EFJ \& JWD & 328.29 \\
\hline 264 & 256.0 & $8 / 20 / 946: 00$ & 15360 & 1110 & 21694.2 & 0.978 & 0.98 & 177 & 53.09 & 53.74 & EFJ \& JWD & 328.32 \\
\hline 265 & 257.0 & $8 / 20 / 947: 00$ & 15420 & 70 & 21757 & 1.047 & 1 & 179 & 53.27 & 53.86 & EFJ \& JWD & 328.2 \\
\hline 266 & 258.0 & $8 / 20 / 948: 00$ & 15480 & 145 & 21821.2 & 1.070 & 0.98 & $173 / 174$ & 53.2 & 53.8 & KRD \& JTL & 328.26 \\
\hline 267 & 259.0 & 8/20/949:00 & 15540 & 220 & 21880.3 & 0.985 & 0.98 & $173 / 174$ & 53.21 & 53.82 & JTL & 328.24 \\
\hline 268 & 260.0 & $8 / 20 / 9410: 00$ & 15600 & 300 & 21940.3 & 1.000 & 1 & $173 / 174$ & 53.2 & 53.78 & $\mathrm{JTL}$ & 328.28 \\
\hline 269 & 261.0 & $8 / 20 / 9411: 00$ & 15660 & 330 & 22000.3 & 1.000 & 1 & $174 / 175$ & 53.22 & 53.78 & KRD & 328.28 \\
\hline 270 & 262.0 & $8 / 20 / 9412: 00$ & 15720 & 400 & 22059.6 & 0.988 & 1 & $174 / 175$ & 53.16 & 53.8 & JTL & 328.26 \\
\hline 271 & 263.0 & $8 / 20 / 9413: 00$ & 15780 & 460 & 22120.1 & 1.008 & 0.99 & $175 / 176$ & 53.25 & 53.8 & JTL & 328.26 \\
\hline
\end{tabular}




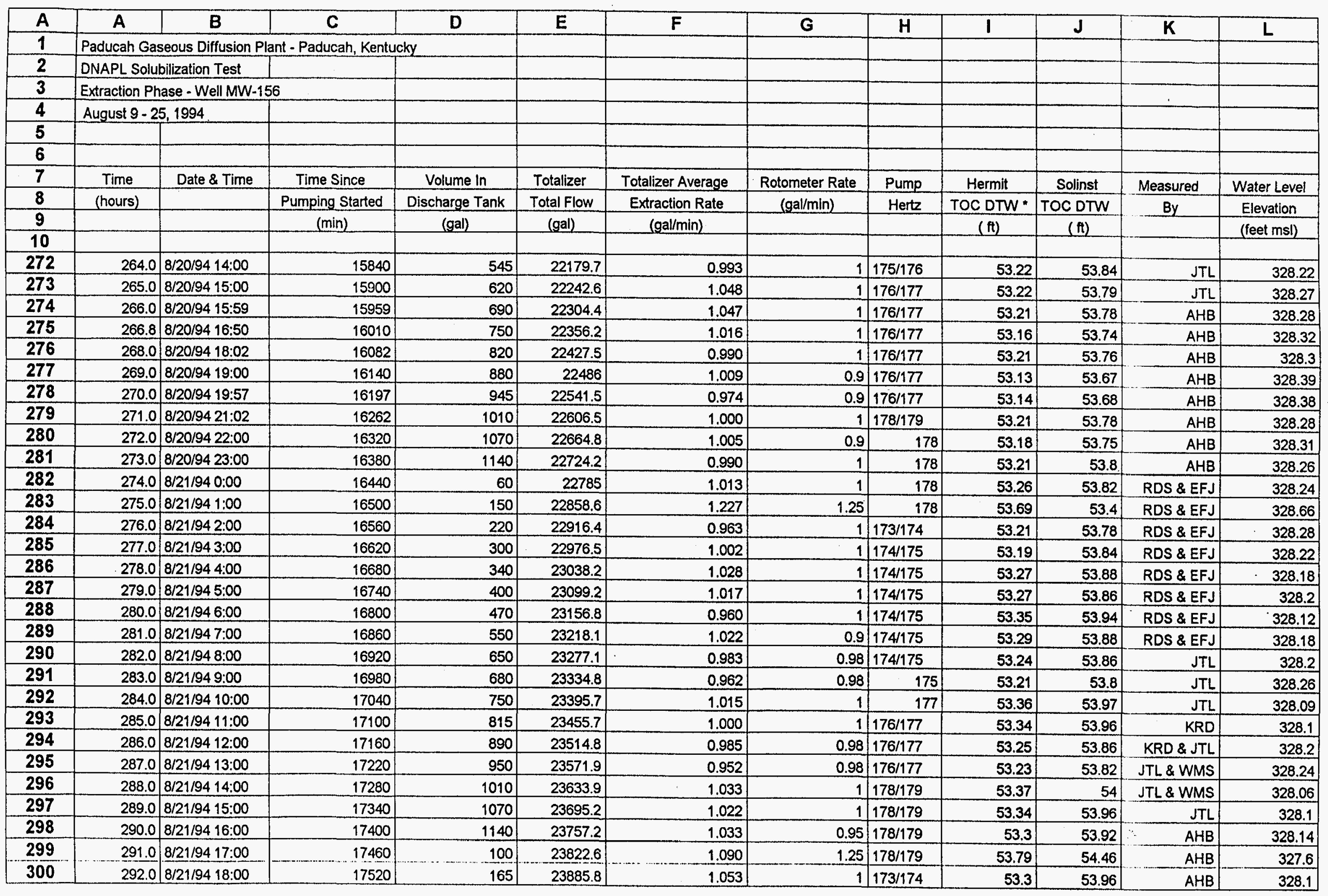




\begin{tabular}{|c|c|c|c|c|c|c|c|c|c|c|c|c|}
\hline A & A & B & $\mathbf{C}$ & D & $\mathbf{E}$ & $\mathbf{F}$ & $\mathbf{G}$ & $\mathrm{H}$ & I & $\mathrm{J}$ & $\mathbf{K}$ & $L$ \\
\hline 1 & \multicolumn{12}{|c|}{ Paducah Gaseous Diffusion Plant - Paducah, Kentucky } \\
\hline 2 & \multirow{2}{*}{\multicolumn{12}{|c|}{ Extraction Phase - Well MW-156 }} \\
\hline 3 & & & & & & & & & & & & \\
\hline 4 & \multicolumn{2}{|c|}{ August $9-25,1994$} & & & & & & & & & & \\
\hline 5 & & & & & & & & & & & & \\
\hline 6 & & & & & & & & & & & & \\
\hline 7 & Time & Date \& Time & Time Since & Volume in & Totalizer & Totalizer Average & Rotometer Rate & Pump & Hermit & Solinst & Measured & Water Level \\
\hline 9 & & & $(\min )$ & (gal) & (gal) & (gal/min) & & & (fi) & $(\mathrm{ft})$ & & (feet msl) \\
\hline 10 & & & & & & & & & & & & \\
\hline 301 & 293.3 & $8 / 21 / 3419: 17$ & 17597 & 220 & 23962.3 & 0.994 & 0.9 & $173 / 174$ & 53.28 & 53.92 & $\mathrm{AHB}$ & 328.14 \\
\hline 302 & 294.2 & $8 / 21 / 9420: 12$ & 17652 & 300 & 24016.8 & 0.991 & 0.9 & $173 / 174$ & 53.26 & 53.9 & AHB & 328.16 \\
\hline 303 & 295.0 & 8/21/94 21:00 & 17700 & 350 & 24070.3 & 1.115 & 1.15 & 177 & 53.56 & 54.24 & $\mathrm{AHB}$ & 327.82 \\
\hline 304 & 296.0 & 8/21/94 22:02 & 17762 & 430 & 24139.3 & 1.113 & 1.12 & 177 & 53.54 & 54.23 & $\mathrm{AHB}$ & 327.83 \\
\hline 305 & 297.0 & $8 / 21 / 9423: 00$ & 17820 & 510 & 24201.6 & 1.074 & 1.12 & 177 & 53.48 & 54.18 & $\mathrm{AHB}$ & 327.88 \\
\hline 306 & 298.0 & $8 / 22 / 940: 00$ & 17880 & 600 & 24276.4 & 1.247 & 1.11 & 177 & 53.47 & 54.2 & SJK & 327.86 \\
\hline 308 & 300.0 & $8 / 22 / 942: 02$ & 18002 & 725 & 24393 & 1.054 & 1 & 177 & 53.41 & 54.12 & SJK & 327.94 \\
\hline 309 & 301.0 & 8/22/943:01 & 18061 & 800 & 24453.1 & 1.019 & 0.98 & 177 & 53.34 & 54.05 & SJK & 328.01 \\
\hline 310 & 302.0 & $8 / 22 / 944: 00$ & 18120 & 870 & 24516.7 & 1.078 & 1.15 & 178 & 53.52 & 54.2 & SJK & 327.86 \\
\hline 311 & 303.0 & $8 / 22 / 945: 00$ & 18180 & 950 & 24580.1 & 1.057 & 1. & 178 & 53.48 & 54.2 & S.JK & 327.86 \\
\hline 312 & 304.0 & $8 / 22 / 946: 00$ & 18240 & 1020 & 24642.6 & 1.042 & 1 & 178 & 53.46 & 54.15 & SJK & 327.91 \\
\hline 313 & 305.0 & $8 / 22 / 947: 01$ & 18301 & 1075 & 24704.8 & 1.020 & 0.98 & 178 & 53.41 & 54.2 & SJK & 327.86 \\
\hline 314 & 306.0 & 8/22/948:00 & 18360 & 1145 & 24769.9 & 1.103 & 1 & $178 / 179$ & 53.45 & 54.15 & JTL & 327.91 \\
\hline 315 & 307.0 & $8 / 22 / 949: 02$ & 18422 & 90 & 24832.7 & 1.013 & 1 & $173 / 174$ & 53.55 & 54.21 & JTL & 327.85 \\
\hline 316 & 308.0 & $8 / 22 / 9410: 00$ & 18480 & 150 & 24889.8 & 0.984 & 0.95 & $173 / 174$ & 53.37 & 54.04 & JTL \& WMS & 328.02 \\
\hline 317 & 309.0 & $8 / 22 / 9411: 00$ & 18540 & 210 & 24951.9 & 1.035 & 1 & $174 / 175$ & 53.5 & 54.17 & KRD & 327.89 \\
\hline 318 & 310.0 & $8 / 22 / 9412: 01$ & 18601 & 300 & 25013.3 & 1.007 & 1 & 175 & 53.43 & 54.13 & $\mathrm{JTL}$ & 327.93 \\
\hline 319 & 311.0 & $8 / 22 / 9413: 00$ & 18660 & 340 & 25072.5 & 1.003 & 0.99 & 175 & 53.4 & 54.11 & JTL & 327.95 \\
\hline 320 & 312.0 & $8 / 22 / 9414: 00$ & 18720 & 400 & 25136.8 & 1.072 & 1.01 & $176 / 177$ & 53.55 & 54.25 & JTL & 327.81 \\
\hline 321 & 313.0 & $8 / 22 / 9415: 00$ & 18780 & 475 & 25200.5 & 1.062 & 1.01 & $176 / 177$ & 53.49 & 54.23 & JTL \& WMS & 327.83 \\
\hline 322 & 314.0 & $8 / 22 / 9416: 00$ & 18840 & 560 & 25261.8 & 1.022 & 1 & $176 / 177$ & 53.45 & 54.12 & $\mathrm{AHB}$ & 327.94 \\
\hline 323 & 315.0 & $8 / 22 / 9417: 00$ & 18900 & 620 & 25321.6 & 0.997 & 0.98 & $176 / 177$ & 53.35 & 54.1 & AHB & 327.96 \\
\hline 326 & 318.0 & $8 / 22 / 9420: 00$ & 19080 & 825 & 25503.5 & 1.075 & 1.01 & $178 / 179$ & 53.54 & 54.26 & $\mathrm{AHB}$ & 327.8 \\
\hline 327 & 319.0 & 8/22/94 21:00 & 19140 & 900 & 25567 & 1.058 & 1 & $178 / 179$ & 53.52 & 54.25 & $\mathrm{AHB}$ & 327.81 \\
\hline 328 & 320.0 & $8 / 22 / 9422: 02$ & 19202 & 975 & 25631.3 & 1.037 & 1 & $178 / 179$ & 53.54 & 54.28 & $\mathrm{AHB}$ & 327.78 \\
\hline 329 & 321.0 & $8 / 22 / 9423: 00$ & 19260 & 1030 & 25690.2 & 1.016 & 1 & $178 / 179$ & 53.51 & 54.25 & $\mathrm{AHB}$ & 327.81 \\
\hline
\end{tabular}




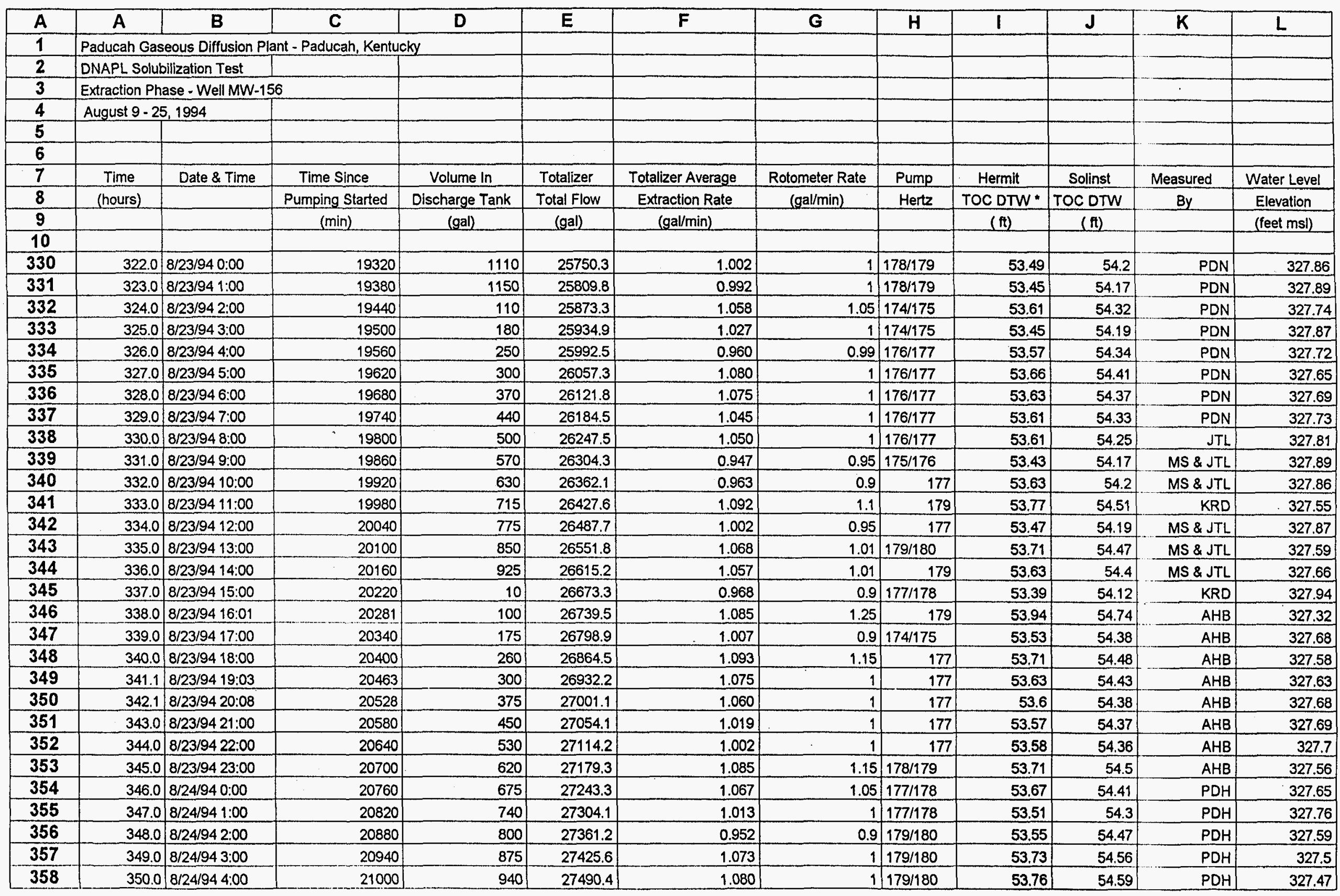




\begin{tabular}{|c|c|c|c|c|c|c|c|c|c|c|c|c|}
\hline $\mathbf{A}$ & A & B & $\mathbf{C}$ & D & $\mathbf{E}$ & $\mathbf{F}$ & $\mathbf{G}$ & $\mathrm{H}$ & $\mathbf{I}$ & $\mathbf{J}$ & $\mathbf{K}$ & $L$ \\
\hline 1 & \multicolumn{4}{|c|}{ Paducah Gaseous Diffusion Plant - Paducah, Kentucky } & & & & & & & & \\
\hline 2 & \multicolumn{2}{|c|}{ DNAPL Solubilization Test } & & & & & & & & & & \\
\hline 3 & \multicolumn{3}{|c|}{ Extraction Phase - Well MW-156 } & & & & & & & & & \\
\hline 4 & \multicolumn{2}{|c|}{ August $9-25,1994$} & & & & & & & & & & \\
\hline \multicolumn{13}{|c|}{ 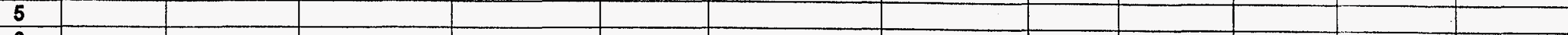 } \\
\hline \multicolumn{13}{|l|}{6} \\
\hline 7 & Time & Date \& Time & Time Since & Volume in & Totalizer & Totalizer Average & Rotometer Rate & Pump & Hermit & Solinst & Measured & Water Level \\
\hline 8 & (hours) & & Pumping Started & Discharge Tank & Total Flow & Extraction Rate & (gal/min) & Hertz & TOC DTW * & TOC DTW & By & Elevation \\
\hline 9 & & & $(\min )$ & (gal) & (gal) & (gal/min) & & & $(\mathrm{f})$ & (ft) & & (feet $\mathrm{msl}$ ) \\
\hline \multicolumn{13}{|l|}{10} \\
\hline 359 & 351.0 & 8/24/945:00 & 21060 & 1025 & 27554 & 1.060 & 1 & $179 / 180$ & 53.67 & 54.5 & $\mathrm{PDH}$ & 327.56 \\
\hline 360 & 352.0 & 8/24/946:00 & 21120 & 1090 & 27614.9 & 1.015 & 1 & $179 / 180$ & 53.61 & 54.46 & $\mathrm{PDH}$ & 327.6 \\
\hline 361 & 353.0 & 8/24/947:00 & 21180 & 1140 & 27673.8 & 0.982 & 1 & $179 / 180$ & 53.61 & 54.4 & $\mathrm{PDH}$ & 327.66 \\
\hline 362 & 355.0 & $8 / 24 / 949: 00$ & 21300 & 110 & 27803.1 & 1.077 & 1.25 & $179 / 180$ & 54.14 & 54.98 & JTL & 327.08 \\
\hline 363 & 356.1 & $8 / 24 / 9410: 06$ & 21366 & 180 & 27868.8 & 0.995 & 0.99 & $174 / 175$ & 53.63 & 54.47 & MS \& JTL & 327.59 \\
\hline 364 & 357.0 & $8 / 24 / 9411: 00$ & 21420 & 250 & 27923.2 & 1.007 & 1 & $175 / 176$ & 53.66 & 54.48 & MS \& JTL & 327.58 \\
\hline 365 & 358.0 & $8 / 24 / 9412: 00$ & 21480 & 300 & 27986.2 & 1.050 & 0.98 & $175 / 176$ & 53.64 & 54.46 & KRD \& JTL & 327.6 \\
\hline 366 & 359.0 & $8 / 24 / 9413: 00$ & 21540 & 365 & 28045.1 & 0.982 & 1 & $175 / 176$ & 53.62 & 54.45 & KRD & 327.61 \\
\hline 367 & 360.0 & $8 / 24 / 9414: 00$ & 21600 & 430 & 28102.8 & 0.962 & 0.98 & $175 / 176$ & 53.52 & 54.36 & MS \& JTL & 327.7 \\
\hline 368 & 361.0 & $8 / 24 / 9415: 00$ & 21660 & 495 & 28162.8 & 1.000 & 0.98 & $176 / 177$ & 53.59 & 54.41 & KRD & 327.65 \\
\hline 369 & 362,1 & $8 / 24 / 9416: 04$ & 21724 & 560 & 28225.2 & 0.975 & 0.95 & $176 / 177$ & 53.5 & 54.48 & AHB & 327.58 \\
\hline 370 & 363.0 & $8 / 24 / 9417: 01$ & 21781 & 650 & 28285.1 & 1.051 & 1 & $178 / 179$ & 53.7 & 54.56 & $\mathrm{AHB}$ & 327.5 \\
\hline 371 & 364.0 & $8 / 24 / 9418: 00$ & 21840 & 720 & 28346.2 & 1.036 & 1 & $178 / 179$ & 53.65 & 54.5 & $\mathrm{AHB}$ & 327.56 \\
\hline 372 & 365.0 & $8 / 24 / 9419: 00$ & 21900 & 770 & 28409 & 1.047 & 0.99 & $178 / 179$ & 53.58 & 53.45 & $\mathrm{AHB}$ & 328.61 \\
\hline 373 & 366.0 & $8 / 24 / 9420: 00$ & 21960 & 850 & 28469.4 & 1.007 & 0.98 & $178 / 179$ & 53.53 & 54.4 & $\mathrm{AHB}$ & 327.66 \\
\hline 374 & 367.0 & $8 / 24 / 9421: 00$ & 22020 & 910 & 28532.4 & 1.050 & 1 & $179 / 180$ & 53.67 & 54.55 & $\mathrm{AHB}$ & 327.51 \\
\hline 375 & 368.0 & $8 / 24 / 9422: 00$ & 22080 & 1000 & 28594.6 & 1.037 & 1 & & 53.64 & 54.53 & $\mathrm{AHB}$ & 327.53 \\
\hline 376 & 369.0 & 8/24/94 23:00 & 22140 & 1060 & 28655.2 & 1.010 & 0.99 & & 53.55 & 54.45 & $\mathrm{AHB}$ & 327.61 \\
\hline 377 & 370.0 & $8 / 25 / 940: 00$ & 22200 & 1125 & 28714.3 & 0.985 & 0.99 & & 53.49 & 54.36 & RS \& RP & 327.7 \\
\hline 378 & 371.0 & $8 / 25 / 941: 00$ & 22260 & 60 & 28772.8 & 0.975 & 0.99 & & 53.51 & 54.38 & RS \& RP & 327.68 \\
\hline 379 & 372.0 & 8/25/94 2:00 & 22320 & 100 & 28837.3 & 1.075 & 1.25 & & 53.73 & 54,6 & RS \& RP & 327.46 \\
\hline 380 & 373.0 & 8/25/943:00 & 22380 & 175 & 28893.5 & 0.937 & 0.99 & & 53.54 & 54.42 & RS \& RP & 327.64 \\
\hline 381 & 374.0 & 8/25/944:00 & 22440 & 245 & 28951.2 & 0.962 & 0.9 & & 53.62 & 54.54 & RS \& RP & 327.52 \\
\hline 382 & 375.0 & 8/25/945:00 & 22500 & 300 & 29015.2 & 1.067 & 1 & & 53.71 & 54.62 & RS \& RP & 327.44 \\
\hline 383 & 376.0 & 8/25/946:00 & 22560 & 370 & 29075.2 & 1.000 & 1 & & 53.7 & 54.6 & RS \& RP & 327.46 \\
\hline 384 & 377.0 & $8 / 25 / 947: 00$ & 22620 & 440 & 29136.7 & 1.025 & 1 & & 53.67 & 54.6 & RS \& RP & 327.46 \\
\hline 385 & 378.0 & 8/25/94 8:00 & 22680 & 510 & 29198.4 & 1.028 & 1 & & 53.69 & .54 .59 & KRD \& JTL & 327.47 \\
\hline 386 & 379.0 & 8/25/94 9:00 & 22740 & 650 & 29258.7 & 1.005 & 0.99 & & 53.66 & 54.56 & KRD \& JTL & 327.5 \\
\hline 387 & 380.0 & $8 / 25 / 9410: 00$ & 22800 & 650 & 29292.4 & 0.562 & 0.3 & & 52.04 & 52.97 & KRD \& JTL & 329.09 \\
\hline
\end{tabular}




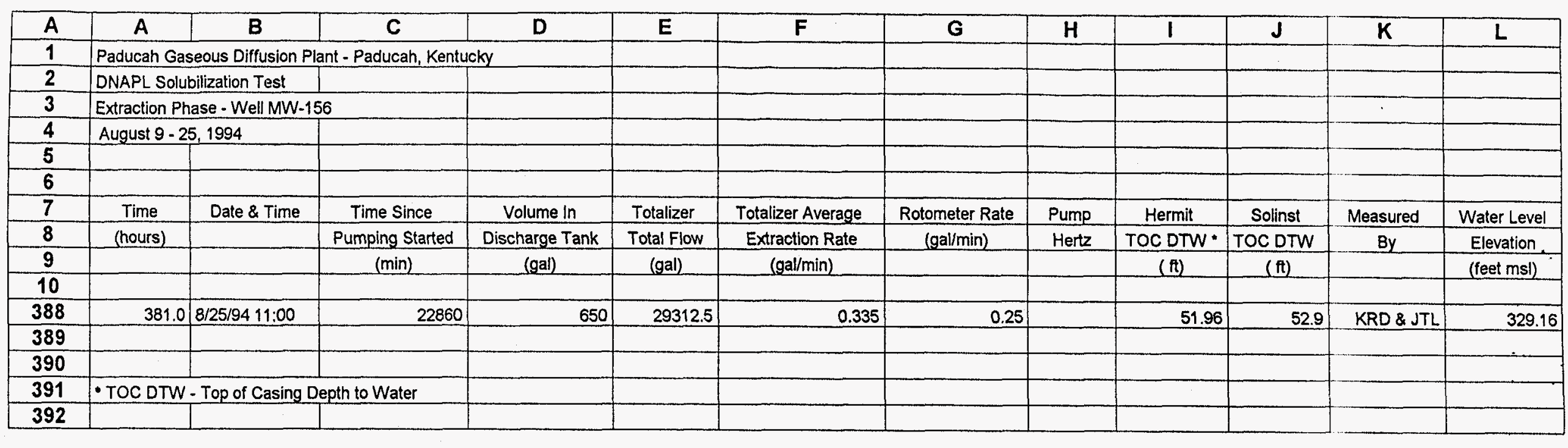


Paducah Gaseous Diffusion Plant

DNAPL Solubilization Test

Water Level in Control Piezometer 109

During the Extraction Phase

August 9 - 25. 1994

\begin{tabular}{llr} 
Date & Time & $\begin{array}{c}\text { Ground Water } \\
\text { Elevation } \\
\text { (feet, } \mathrm{msI}\end{array}$ \\
\hline & & \\
\hline & & \\
\hline 09-Aug-94 & $12: 00 \mathrm{AM}$ & 331.607 \\
09-Aug-94 & $01: 00 \mathrm{AM}$ & 331.529 \\
09-Aug-94 & 02:00 AM & 331.591 \\
09-Aug-94 & $03: 00 \mathrm{AM}$ & 331.591 \\
09-Aug-94 & $04: 00 \mathrm{AM}$ & 331.619 \\
09-Aug-94 & $05: 00 \mathrm{AM}$ & 331.591 \\
09-Aug-94 & $06: 00 \mathrm{AM}$ & 331.591 \\
09-Aug-94 & $07: 00 \mathrm{AM}$ & 331.551 \\
09-Aug-94 & $08: 00 \mathrm{AM}$ & 331.529 \\
09-Aug-94 & $09: 00 \mathrm{AM}$ & 331.512 \\
09-Aug-94 & $10: 00 \mathrm{AM}$ & 331.5 \\
09-Aug-94 & $11: 00 \mathrm{AM}$ & 331.495 \\
09-Aug-94 & $12: 00 \mathrm{PM}$ & 331.5 \\
09-Aug-94 & $01: 00 \mathrm{PM}$ & 331.529 \\
09-Aug-94 & $02: 00 \mathrm{PM}$ & 331.54 \\
09-Aug-94 & $03: 00 \mathrm{PM}$ & 331.54 \\
09-Aug-94 & $04: 00 \mathrm{PM}$ & 331.557 \\
09-Aug-94 & $05: 00 \mathrm{PM}$ & 331.557 \\
09-Aug-94 & $06: 00 \mathrm{PM}$ & 331.545 \\
09-Aug-94 & $07: 00 \mathrm{PM}$ & 331.523 \\
09-Aug-94 & $08: 00 \mathrm{PM}$ & 331.495 \\
09-Aug-94 & $09: 00 \mathrm{PM}$ & 331.489 \\
09-Aug-94 & $10: 00 \mathrm{PM}$ & 331.489 \\
09-Aug-94 & $11: 00 \mathrm{PM}$ & 331.489 \\
10-Aug-94 & $12: 00 \mathrm{PM}$ & 331.495 \\
10-Aug-94 & $01: 00 \mathrm{AM}$ & 331.484 \\
10-Aug-94 & $02: 00 \mathrm{AM}$ & 331.489 \\
10-Aug-94 & $03: 00 \mathrm{AM}$ & 331.484 \\
10-Aug-94 & $04: 00 \mathrm{AM}$ & 331.478 \\
10-Aug-94 & $05: 00 \mathrm{AM}$ & 331.45 \\
10-Aug-94 & $06: 00 \mathrm{AM}$ & 331.444 \\
10-Aug-94 & $07: 00 \mathrm{AM}$ & 331.433 \\
10-Aug-94 & $08: 00 \mathrm{AM}$ & 331.433 \\
10-Aug-94 & $09: 00 \mathrm{AM}$ & 331.433 \\
10-Aug-94 & $10: 00 \mathrm{AM}$ & 331.444 \\
10-Aug-94 & $11: 00 \mathrm{AM}$ & 331.45 \\
10-Aug-94 & $12: 00 \mathrm{PM}$ & 331.455 \\
10-Aug-94 & $01: 00 \mathrm{PM}$ & 331.467 \\
10-Aug-94 & $02: 00 \mathrm{PM}$ & 331.489 \\
10-Aug-94 & $03: 00 \mathrm{PM}$ & 331.5 \\
10-Aug-94 & $04: 00 \mathrm{PM}$ & 331.512 \\
10-Aug-94 & $05: 00 \mathrm{PM}$ & 331.523 \\
10-Aug-94 & $06: 00 \mathrm{PM}$ & 331.529
\end{tabular}


Date Time Ground Water

Elevation

(feet, msl)

\begin{tabular}{|c|c|c|}
\hline 10-Aug-94 & 02:00 PM & 331.489 \\
\hline 10-Aug-94 & 03:00 PM & 331.5 \\
\hline 10-Aug-94 & 04:00 PM & 331.512 \\
\hline 10-Aug-94 & 05:00 PM & 331.523 \\
\hline 10-Aug-94 & 06:00 PM & 331.529 \\
\hline 10-Aug-94 & 07:00 PM & 331.517 \\
\hline 10-Aug-94 & 08:00 PM & 331.495 \\
\hline 10-Aug-94 & 09:00 PM & 331.489 \\
\hline 10-Aug-94 & 10:00 PM & 331.489 \\
\hline 10-Aug-94 & $11: 00 \mathrm{PM}$ & 331.472 \\
\hline 11-Aug-94 & 12:00 AM & 331.472 \\
\hline 11-Aug-94 & 01:00 AM & 331.472 \\
\hline 11-Aug-94 & 02:00 AM & 331.472 \\
\hline 11-Aug-94 & 03:00 AM & 331.472 \\
\hline 11-Aug-94 & 04:00 AM & 331.472 \\
\hline 11-Aug-94 & 05:00 AM & 331.455 \\
\hline 11-Aug-94 & $06: 00 \mathrm{AM}$ & 331.444 \\
\hline 11-Aug-94 & 07:00 AM & 331.433 \\
\hline 11-Aug-94 & 08:00 AM & 331.433 \\
\hline 11-Aug-94 & 09:00 AM & 331.427 \\
\hline 11-Aug-94 & 10:00 AM & 331.422 \\
\hline 11-Aug-94 & $11: 00 \mathrm{AM}$ & 331.45 \\
\hline 11-Aug-94 & 12:00 PM & 331.455 \\
\hline 11-Aug-94 & 01:00 PM & 331.472 \\
\hline 11-Aug-94 & 02:00 PM & 331.39 \\
\hline 11-Aug-94 & 03:00 PM & 331.407 \\
\hline 11-Aug-94 & 04:00 PM & 331.407 \\
\hline 11-Aug-94 & 05:00 PM & 331.413 \\
\hline 11-Aug-94 & 06:00 PM & 331.413 \\
\hline 11-Aug-94 & 07:00 PM & 331.407 \\
\hline 11-Aug-94 & 08:00 PM & 331.39 \\
\hline 11-Aug-94 & 09:00 PM & 331.362 \\
\hline 11-Aug-94 & 10:00 PM & 331.356 \\
\hline 11-Aug-94 & 11:00 PM & 331.356 \\
\hline 12-Aug-94 & $12: 00 \mathrm{PM}$ & 331.351 \\
\hline 12-Aug-94 & 01:00 AM & 331.351 \\
\hline 12-Aug-94 & 02:00 AM & 331.351 \\
\hline 12-Aug-94 & 03:00 AM & $331: 345$ \\
\hline 12-Aug-94 & 04:00 AM & 331.339 \\
\hline 12-Aug-94 & 05:00 AM & 331.323 \\
\hline 12-Aug-94 & 06:00 AM & 331.317 \\
\hline 12-Aug-94 & 07:00 AM & 331.317 \\
\hline 12-Aug-94 & 08:00 AM & 331.323 \\
\hline 12-Aug-94 & 09:00 AM & 331.311 \\
\hline 12-Aug-94 & $10: 00 \mathrm{AM}$ & 331.306 \\
\hline 12-Aug-94 & 11:00 AM & 331.3 \\
\hline 12-Aug-94 & 12:00 PM & 331.311 \\
\hline 12-Aug-94 & 01:00 PM & 331.317 \\
\hline 12-Aug-94 & 02:00 PM & 331.345 \\
\hline 12-Aug-94 & 03:00 PM & 331.351 \\
\hline 12-Aug-94 & 04:00 PM & 331.356 \\
\hline
\end{tabular}


Date Time Ground Water

Elevation

(feet, $\mathrm{msl}$ )

\begin{tabular}{|c|c|c|}
\hline 12-Aug-94 & 05:00 PM & 331.356 \\
\hline 12-Aug-94 & 06:00 PM & 331.356 \\
\hline 12-Aug-94 & 07:00 PM & 331.345 \\
\hline 12-Aug-94 & 08:00 PM & 331.328 \\
\hline 12-Aug-94 & 09:00 PM & 331.306 \\
\hline 12-Aug-94 & 10:00 PM & 331.311 \\
\hline 12-Aug-94 & $11: 00 \mathrm{PM}$ & 331.306 \\
\hline 13-Aug-94 & 12:00 PM & 331.311 \\
\hline 13-Aug-94 & $01: 00 \mathrm{AM}$ & 331.311 \\
\hline 13-Aug-94 & 02:00 AM & 331.323 \\
\hline 13-Aug-94 & $03: 00 \mathrm{AM}$ & 331.328 \\
\hline 13-Aug-94 & 04:00 AM & 331.3 \\
\hline 13-Aug-94 & 05:00 AM & 331.294 \\
\hline 13-Aug-94 & 06:00 AM & 331.283 \\
\hline 13-Aug-94 & 07:00 AM & 331.272 \\
\hline 13-Aug-94 & 08:00 AM & 331.272 \\
\hline 13-Aug-94 & 09:00 AM & 331.294 \\
\hline 13-Aug-94 & $10: 00 \mathrm{AM}$ & 331.294 \\
\hline 13-Aug-94 & $11: 00 \mathrm{AM}$ & 331.311 \\
\hline 13-Aug-94 & 12:00 PM & 331.323 \\
\hline 13-Aug-94 & 01:00 PM & 331.334 \\
\hline 13-Aug-94 & 02:00 PM & 331.351 \\
\hline 13-Aug-94 & 03:00 PM & 331.373 \\
\hline 13-Aug-94 & 04:00 PM & 331.39 \\
\hline 13-Aug-94 & 05:00 PM & 331.39 \\
\hline 13-Aug-94 & 06:00 PM & 331.396 \\
\hline 13-Aug-94 & 07:00 PM & 331.396 \\
\hline 13-Aug-94 & 08:00 PM & 331.368 \\
\hline 13-Aug-94 & 09:00 PM & 331.356 \\
\hline 13-Aug-94 & 10:00 PM & 331.373 \\
\hline 13-Aug-94 & 11:00 PM & 331.385 \\
\hline 14-Aug-94 & 12:00 AM & 331.379 \\
\hline 14-Aug-94 & 01:00 AM & 331.385 \\
\hline 14-Aug-94 & 02:00 AM & 331.385 \\
\hline 14-Aug-94 & 03:00 AM & 331.379 \\
\hline 14-Aug-94 & 04:00 AM & 331.379 \\
\hline 14-Aug-94 & 05:00 AM & 331.368 \\
\hline 14-Aug-94 & $06: 00 \mathrm{AM}$ & 331.362 \\
\hline 14-Aug-94 & 07:00 AM & 331.339 \\
\hline 14-Aug-94 & 08:00 AM & 331.339 \\
\hline 14-Aug-94 & 09:00 AM & 331.328 \\
\hline 14-Aug-94 & $10: 00 \mathrm{AM}$ & 331.323 \\
\hline 14-Aug-94 & $11: 00$ AM & 331.323 \\
\hline 14-Aug-94 & 12:00 PM & 331.323 \\
\hline 14-Aug-94 & 01:00 PM & 331.328 \\
\hline 14-Aug-94 & 02:00 PM & 331.339 \\
\hline 14-Aug-94 & 03:00 PM & 331.373 \\
\hline 14-Aug-94 & 04:00 PM & 331.368 \\
\hline 14-Aug-94 & 05:00 PM & 331.345 \\
\hline 14-Aug-94 & 06:00 PM & 331.323 \\
\hline 14-Aug-94 & 07:00 PM & 331.311 \\
\hline
\end{tabular}




\begin{tabular}{|c|c|c|}
\hline Date & Time & $\begin{array}{c}\text { Ground Water } \\
\text { Elevation } \\
\text { (feet, msl) }\end{array}$ \\
\hline 14-Aug-94 & 08:00 PM & 331.283 \\
\hline 14-Aug-94 & 09:00 PM & 331.249 \\
\hline 14-Aug-94 & $10: 00 \mathrm{PM}$ & 331.232 \\
\hline 14-Aug-94 & 11:00 PM & 331.221 \\
\hline 15-Aug-94 & $12: 00 \mathrm{AM}$ & 331.221 \\
\hline 15-Aug-94 & $01: 00 \mathrm{AM}$ & 331.227 \\
\hline 15-Aug-94 & 02:00 AM & 331.227 \\
\hline 15-Aug-94 & 03:00 AM & 331.221 \\
\hline 15-Aug-94 & 04:00 AM & 331.21 \\
\hline 15-Aug-94 & 05:00 AM & 331.199 \\
\hline 15-Aug-94 & 06:00 AM & 331.182 \\
\hline 15-Aug-94 & 07:00 AM & 331.165 \\
\hline 15-Aug-94 & 08:00 AM & 331.17 \\
\hline 15-Aug-94 & 09:00 AM & 331.159 \\
\hline 15-Aug-94 & $10: 00 \mathrm{AM}$ & 331.159 \\
\hline 15-Aug-94 & $11: 00 \mathrm{AM}$ & 331.17 \\
\hline 15-Aug-94 & $12: 00 \mathrm{PM}$ & 331.187 \\
\hline 15-Aug-94 & 01:00 PM & 331.21 \\
\hline 15-Aug-94 & 02:00 PM & 331.232 \\
\hline 15-Aug-94 & 03:00 PM & 331.261 \\
\hline 15-Aug-94 & 04:00 PM & 331.261 \\
\hline 15-Aug-94 & 05:00 PM & 331.255 \\
\hline 15-Aug-94 & 06:00 PM & 331.249 \\
\hline 15-Aug-94 & 07:00 PM & 331.238 \\
\hline 15-Aug-94 & 08:00 PM & 331.227 \\
\hline 15-Aug-94 & 09:00 PM & 331.221 \\
\hline 15-Aug-94 & $10: 00 \mathrm{PM}$ & 331.216 \\
\hline 15-Aug-94 & 11:00 PM & 331.216 \\
\hline 16-Aug-94 & $12: 00 \mathrm{AM}$ & 331.227 \\
\hline 16-Aug-94 & 01:00 AM & 331.227 \\
\hline 16-Aug-94 & $02: 00 \mathrm{AM}$ & 331.232 \\
\hline 16-Aug-94 & $03: 00 \mathrm{AM}$ & 331.232 \\
\hline 16-Aug-94 & 04:00 AM & 331.227 \\
\hline 16-Aug-94 & 05:00 AM & 331.21 \\
\hline 16-Aug-94 & 06:00 AM & 331.199 \\
\hline 16-Aug-94 & 07:00 AM & 331.187 \\
\hline 16-Aug-94 & 08:00 AM & 331.193 \\
\hline 16-Aug-94 & 09:00 AM & 331.193 \\
\hline 16-Aug-94 & $10: 00 \mathrm{AM}$ & 331.193 \\
\hline 16-Aug-94 & $11: 00 \mathrm{AM}$ & 331.204 \\
\hline 16-Aug-94 & $12: 00 \mathrm{PM}$ & 331.221 \\
\hline 16-Aug-94 & 01:00 PM & 331.244 \\
\hline 16-Aug-94 & 02:00 PM & 331.255 \\
\hline 16-Aug-94 & 03:00 PM & 331.272 \\
\hline 16-Aug-94 & 04:00 PM & 331.272 \\
\hline 16-Aug-94 & 05:00 PM & 331.278 \\
\hline 16-Aug-94 & $06: 00$ PM & 331.278 \\
\hline 16-Aug-94 & 07:00 PM & 331.266 \\
\hline 16-Aug-94 & 08:00 PM & 331.255 \\
\hline 16-Aug-94 & 09:00 PM & 331.244 \\
\hline 16-Aug-94 & 10:00 PM & 331.244 \\
\hline
\end{tabular}


Date Time Ground Water

Elevation

(feet, msl)

16-Aug-94

17-Aug-94

17-Aug-94

17-Aug-94

17-Aug-94

17-Aug-94

17-Aug-94

17-Aug-94

17-Aug-94

17-Aug-94

17-Aug-94

17-Aug-94

17-Aug-94

17-Aug-94

17-Aug-94

17-Aug-94

17-Aug-94

17-Aug-94

17-Aug-94

17-Aug-94

17-Aug-94

17-Aug-94

17-Aug-94

17-Aug-94

17-Aug-94

18-Aug-94

18-Aug-94

18-Aug-94

18-Aug-94

18-Aug-94

18-Aug-94

18-Aug-94

18-Aug-94

18-Aug-94

18-Aug-94

18-Aug-94

18-Aug-94

18-Aug-94

18-Aug-94

18-Aug-94

18-Aug-94

18-Aug-94

18-Aug-94

18-Aug-94

18-Aug-94

18-Aug-94

18-Aug-94

18-Aug-94

18-Aug-94

19-Aug-94

19-Aug-94

11:00 PM

331.238

12:00 AM

331.244

01:00 AM

331.249

02:00 AM

331.244

03:00 AM

331.238

331.238

04:00 AM

331.216

05:00 AM

331.187

331.159

07:00 AM

08:00 AM

331.142

09:00 AM

10:00 AM

331.159

331.154

331.159

331.176

331.182

331.199

331.199

331.204

331.21

331.187

331.165

331.148

331.137

331.125

331.125

331.12

331.137

331.131

331.125

331.114

331.08

331.063

331.047

331.052

331.047

331.058

331.069

331.086

331.086

331.114

331.131

331.142

331.148

331.142

331.131

331.114

331.103

331.097

331.097

331.092

331.097 
Date Time Ground Water

Elevation

(feet, $\mathrm{msl}$ )

\begin{tabular}{|c|c|c|}
\hline 19-Aug-94 & $02: 00 \mathrm{AM}$ & 331.097 \\
\hline 19-Aug-94 & $03: 00 \mathrm{AM}$ & 331.097 \\
\hline 19-Aug-94 & $04: 00 \mathrm{AM}$ & 331.086 \\
\hline 19-Aug-94 & 05:00 AM & 331.075 \\
\hline 19-Aug-94 & 06:00 AM & 331.058 \\
\hline 19-Aug-94 & 07:00 AM & 331.047 \\
\hline 19-Aug-94 & 08:00 AM & 331.063 \\
\hline 19-Aug-94 & 09:00 AM & 331.063 \\
\hline 19-Aug-94 & $10: 00 \mathrm{AM}$ & 331.069 \\
\hline 19-Aug-94 & $11: 00 \mathrm{AM}$ & 331.086 \\
\hline 19-Aug-94 & $12: 00 \mathrm{PM}$ & 331.097 \\
\hline 19-Aug-94 & 01:00 PM & 331.097 \\
\hline 19-Aug-94 & 02:00 PM & 331.12 \\
\hline 19-Aug-94 & 03:00 PM & 331.159 \\
\hline 19-Aug-94 & 04:00 PM & 331.193 \\
\hline 19-Aug-94 & 05:00 PM & 331.182 \\
\hline 19-Aug-94 & 06:00 PM & 331.159 \\
\hline 19-Aug-94 & 07:00 PM & 331.154 \\
\hline 19-Aug-94 & 08:00 PM & 331.148 \\
\hline 19-Aug-94 & 09:00 PM & 331.148 \\
\hline 19-Aug-94 & 10:00 PM & 331.148 \\
\hline 19-Aug-94 & 11:00 PM & 331.154 \\
\hline 20-Aug-94 & 12:00 PM & 331.148 \\
\hline 20-Aug-94 & $01: 00 \mathrm{AM}$ & 331.159 \\
\hline 20-Aug-94 & $02: 00 \mathrm{AM}$ & 331.17 \\
\hline 20-Aug-94 & 03:00 AM & 331.17 \\
\hline 20-Aug-94 & $04: 00 \mathrm{AM}$ & 331.17 \\
\hline 20-Aug-94 & $05: 00 \mathrm{AM}$ & 331.159 \\
\hline 20-Aug-94 & $06: 00 \mathrm{AM}$ & 331.142 \\
\hline 20-Aug-94 & 07:00 AM & 331.114 \\
\hline 20-Aug-94 & $08: 00 \mathrm{AM}$ & 331.12 \\
\hline 20-Aug-94 & $09: 00 \mathrm{AM}$ & 331.103 \\
\hline 20-Aug-94 & $10: 00 \mathrm{AM}$ & 331.125 \\
\hline 20-Aug-94 & $11: 00 \mathrm{AM}$ & 331.131 \\
\hline 20-Aug-94 & 12:00 PM & 331.131 \\
\hline 20-Aug-94 & 01:00 PM & 331.17 \\
\hline 20-Aug-94 & 02:00 PM & 331.154 \\
\hline 20-Aug-94 & 03:00 PM & 331.17 \\
\hline 20-Aug-94 & 04:00 PM & 331.165 \\
\hline 20-Aug-94 & 05:00 PM & 331.17 \\
\hline 20-Aug-94 & 06:00 PM & 331.17 \\
\hline 20-Aug-94 & 07:00 PM & 331.165 \\
\hline 20-Aug-94 & 08:00 PM & 331.142 \\
\hline 20-Aug-94 & 09:00 PM & 331.125 \\
\hline 20-Aug-94 & 10:00 PM & 331.12 \\
\hline 20-Aug-94 & $11: 00$ PM & 331.109 \\
\hline 21-Aug-94 & $12: 00 \mathrm{PM}$ & 331.097 \\
\hline 21-Aug-94 & 01:00 AM & 331.103 \\
\hline 21-Aug-94 & 02:00 AM & 331.165 \\
\hline 21-Aug-94 & 03:00 AM & 331.159 \\
\hline 21-Aug-94 & $04: 00 \mathrm{AM}$ & 331.125 \\
\hline
\end{tabular}


Date Time Ground Water

Elevation

(feet, $\mathrm{msl}$ )

21-Aug-94

21-Aug-94

21-Aug-94

21-Aug-94

21-Aug-94

21-Aug-94

21-Aug-94

21-Aug-94

21-Aug-94

21-Aug-94

21-Aug-94

21-Aug-94

21-Aug-94

21-Aug-94

21-Aug-94

21-Aug-94

21-Aug-94

21-Aug-94

21-Aug-94

22-Aug-94

22-Aug-94

22-Aug-94

22-Aug-94

22-Aug-94

22-Aug-94

22-Aug-94

22-Aug-94

22-Aug-94

22-Aug-94

22-Aug-94

22-Aug-94

22-Aug-94

22-Aug-94

22-Aug-94

22-Aug-94

22-Aug-94

22-Aug-94

22-Aug-94

22-Aug-94

22-Aug-94

22-Aug-94

22-Aug-94

22-Aug-94

23-Aug-94

23-Aug-94

23-Aug-94

23-Aug-94

23-Aug-94

23-Aug-94

23-Aug-94

23-Aug-94
05:00 AM

06:00 AM

07:00 AM

08:00 AM

09:00 AM

10:00 AM

11:00 AM

12:00 PM

01:00 PM

02:00 PM

03:00 PM

04:00 PM

05:00 PM

06:00 PM

07:00 PM

08:00 PM

09:00 PM

10:00 PM

11:00 PM

12:00 PM

01:00 AM

02:00 AM

03:00 AM

04:00 AM

05:00 AM

06:00 AM

07:00 AM

08:00 AM

09:00 AM

10:00 AM

11:00 AM

12:00 PM

01:00 PM

02:00 PM

03:00 PM

04:00 PM

05:00 PM

06:00 PM

07:00 PM

08:00 PM

09:00 PM

10:00 PM

11:00 PM

12:00 PM

01:00 AM

02:00 AM

03:00 AM

04:00 AM

05:00 AM

06:00 AM

07:00 AM
331.086

331.047

331.013

331.002

330.945

330.894

330.911

330.934

330.956

330.985

331.002

331.002

331.007

331.002

330.985

330.968

330.951

330.945

330.94

330.94

330.934

330.923

330.917

330.894

330.872

330.838

330.827

330.821

330.821

330.816

330.821

330.844

330.849

330.855

330.861

330.855

330.855

330.861

330.849

330.821

330.799

330.787

330.782

330.771

330.782

330.771

330.771

330.754

330.737

330.709

330.68 
Date Time Ground Water

Elevation

(feet, msl)

\begin{tabular}{|c|c|c|}
\hline 23-Aug-94 & 08:00 AM & 330.664 \\
\hline 23-Aug-94 & 09:00 AM & 330.664 \\
\hline 23-Aug-94 & $10: 00 \mathrm{AM}$ & 330.652 \\
\hline 23-Aug-94 & 11:00 AM & 330.664 \\
\hline 23-Aug-94 & 12:00 PM & 330.675 \\
\hline 23-Aug-94 & 01:00 PM & 330.669 \\
\hline 23-Aug-94 & 02:00 PM & 330.692 \\
\hline 23-Aug-94 & 03:00 PM & 330.697 \\
\hline 23-Aug-94 & 04:00 PM & 330.697 \\
\hline 23-Aug-94 & 05:00 PM & 330.692 \\
\hline 23-Aug-94 & 06:00 PM & 330.686 \\
\hline 23-Aug-94 & 07:00 PM & 330.68 \\
\hline 23-Aug-94 & 08:00 PM & 330.664 \\
\hline 23-Aug-94 & 09:00 PM & 330.652 \\
\hline 23-Aug-94 & 10:00 PM & 330.647 \\
\hline 23-Aug-94 & 11:00 PM & 330.647 \\
\hline 24-Aug-94 & 12:00 PM & 330.641 \\
\hline 24-Aug-94 & $01: 00 \mathrm{AM}$ & 330.635 \\
\hline 24-Aug-94 & 02:00 AM & 330.618 \\
\hline 24-Aug-94 & 03:00 AM & $330: 607$ \\
\hline 24-Aug-94 & 04:00 AM & 330.602 \\
\hline 24-Aug-94 & 05:00 AM & 330.59 \\
\hline 24-Aug-94 & 06:00 AM & 330.562 \\
\hline 24-Aug-94 & 07:00 AM & 330.545 \\
\hline 24-Aug-94 & 08:00 AM & 330.528 \\
\hline 24-Aug-94 & 09:00 AM & 330.517 \\
\hline 24-Aug-94 & 10:00 AM & 330.528 \\
\hline 24-Aug-94 & 11:00 AM & 330.551 \\
\hline 24-Aug-94 & 12:00 PM & 330.551 \\
\hline 24-Aug-94 & 01:00 PM & 330.585 \\
\hline 24-Aug-94 & 02:00 PM & 330.613 \\
\hline 24-Aug-94 & 03:00 PM & 330.664 \\
\hline 24-Aug-94 & 04:00 PM & 3.30 .647 \\
\hline 24-Aug-94 & 05:00 PM & 330.635 \\
\hline 24-Aug-94 & 06:00 PM & 330.63 \\
\hline 24-Aug-94 & 07:00 PM & 330.618 \\
\hline 24-Aug-94 & 08:00 PM & 330.602 \\
\hline 24-Aug-94 & 09:00 PM & 330.579 \\
\hline 24-Aug-94 & 10:00 PM & 330.568 \\
\hline 24-Aug-94 & $11: 00$ PM & 330.568 \\
\hline 25-Aug-94 & 12:00 PM & 330.551 \\
\hline 25-Aug-94 & 01:00 AM & 330.54 \\
\hline 25-Aug-94 & 02:00 AM & 330.54 \\
\hline 25-Aug-94 & 03:00 AM & 330.54 \\
\hline 25-Aug-94 & 04:00 AM & 330.534 \\
\hline 25-Aug-94 & 05:00 AM & 330.511 \\
\hline 25-Aug-94 & 06:00 AM & 330.495 \\
\hline 25-Aug-94 & 07:00 AM & 330.483 \\
\hline 25-Aug-94 & 08:00 AM & 330.478 \\
\hline 25-Aug-94 & 09:00 AM & 330.489 \\
\hline 25-Aug-94 & 10:00 AM & 330.5 \\
\hline
\end{tabular}




\begin{tabular}{ccc} 
Date & Time & $\begin{array}{c}\text { Ground Water } \\
\text { Elevation } \\
\text { (feet, msl) }\end{array}$ \\
\hline & & \\
\hline 25-Aug-94 & $11: 00$ AM & 330.511 \\
25-Aug-94 & $12: 00$ PM & 330.523 \\
25-Aug-94 & 01:00 PM & 330.528 \\
25-Aug-94 & 02:00 PM & 330.557 \\
25-Aug-94 & 03:00 PM & 330.562 \\
25-Aug-94 & 04:00 PM & 330.579 \\
25-Aug-94 & $05: 00$ PM & 330.585 \\
25-Aug-94 & 06:00 PM & 330.585 \\
25-Aug-94 & $07: 00$ PM & 330.585 \\
25-Aug-94 & $08: 00$ PM & 330.573 \\
25-Aug-94 & $09: 00$ PM & 330.562 \\
25-Aug-94 & $10: 00$ PM & 330.562
\end{tabular}




\title{
Appendix D
}

\author{
MW-156 \\ Gas Chromatograph Data
}


8-4-94 MW156

Stand

Conc

$(\mathrm{mg} / \mathrm{L})$ Area 1

0

$\begin{array}{lll}150 & 13350 & 13568\end{array}$

$\begin{array}{lll}371 & 21339 & 21110\end{array}$

$131546096 \quad 52493$

$1947 \quad 70198 \quad 74570$
Fit

Avg. Conc

$(\mathrm{mg} / \mathrm{L}) \quad$ Std Err of $Y$ Est

$R$ Squared

No. of Observations

$13459 \quad 149 \quad$ Degrees of Freedom

$21225 \quad 389$

$49857 \quad 1274$

$72384 \quad 1971$
Regression Output:

8653

1155

0.999

4

2
Sample

Numbe Area 1

$1 \quad 19971$

422198

$5 \quad 19982$

717900

81909018158

$10 \quad 20799$

1122002

1218733

$13 \quad 21175$

$14 \quad 18338$

1520997

$16 \quad 18356$

$\begin{array}{lll}17 & 21428 & 19156\end{array}$

$18 \quad 19232$

$\begin{array}{lll}19 & 22646 & 20008\end{array}$

$20 \quad 18105 \quad 22421$
Avg. Conc.

Area 2 Area 3 Area (mg/L)

$20164 \quad 20068 \quad 353$

$\begin{array}{llll}19141 & 20183 & 20507 & 367\end{array}$

$19982 \quad 350$

$19069 \quad 322$

$18624 \quad 308$

$20799 \quad 376$

$19912 \quad 348$

$18733 \quad 312$

$21175 \quad 387$

$18338 \quad 300$

$20997 \quad 382$

$18356 \quad 300$

$20157 \quad 356$

$19232 \quad 327$

$21327 \quad 392$

$20263 \quad 359$
$X$ Coefficient(s) $\quad 32.33$

Std Err of Coef. $\quad 0.796$ 
Stand

Conc

(mg/L) Area 1 Area 2 Area 3

0

$\begin{array}{lll}0.9 & 49.1 & 45.5\end{array}$

$\begin{array}{lll}3.3 & 402.9 & 432.6\end{array}$

$\begin{array}{lll}15.0 & 2301.7 & 2299.6\end{array}$
Fit

Avg. Conc

Area $(\mathrm{mg} / \mathrm{L})$

47
418
2301

Regression Output:

Constan

Std Err of Y Est

$-101.12$

12.0214

$R$ Squared

0.99995

No. of Observations

Degrees of Freedom

1
Sample

Numbe Area 1 Area 2 Area 3 40 too small

$41 \quad 42.2$

$43 \quad 114$

$44 \quad 198.8$

$45 \quad 382$

$\begin{array}{ll}46 & 460.7\end{array}$

$48 \quad 561$

$49 \quad 729$

$50 \quad 826$

$51 \quad 902$

$52 \quad 1002$

$53 \quad 1076$

$54 \quad 1185$

$55 \quad 1192$

$56 \quad 1344$

$57 \quad 1628$

$58 \quad 1706$

$59 \quad 1271$

$61 \quad 1780$

$62 \quad 1655$

$63 \quad 1623$

$\begin{array}{ll}64 & 1659.8\end{array}$

$\begin{array}{ll}65 & 1782\end{array}$

$\begin{array}{ll}66 & 1689\end{array}$

$\begin{array}{ll}67 & 1874\end{array}$

$68 \quad 1763$

$70 \quad 1664$
Avg. Conc.

Area (mg/L)

$0<1$

$42 \quad 1$

$114 \quad 1$

$\begin{array}{llll}221.5 & 240 & 220 & 2\end{array}$

$382 \quad 3$

$461 \quad 4$

561.4

$729 \quad 5$

$826 \quad 6$

9026

$1002 \quad 7$

$1076 \quad 7$

$1185-8$

11928

134499

$1628 \quad 11$

$1706 . \quad 11$

$\begin{array}{llll}1406 & 1323 & 1333 & 9\end{array}$

$1780 \quad 12$

$1655 \quad 11$

$1623 \quad 11$

$1660 \quad 11$

$1782 \quad 12$

$1689 \quad 11$

$1874 \quad 12$

$1763 \quad 12$

$1664 \quad 11$

Std Err of Coef. $\quad 1.126$ 
8-11-94 MW156

Stand

Conc

(mg/L) Area 1 Area 2

0

$\begin{array}{lll}0.9 & 141 & 141.8\end{array}$

$\begin{array}{llll}3.3 & 579.3 & 574.7\end{array}$

$\begin{array}{lll}15.0 & 2435 & 2389.8\end{array}$
Fit

Avg. Conc

Area 3 Area (mg/L)

141

577

2412
Regression Output:

23.3665

35.4041

0.99957

R Squared

No. of Observations

Degrees of Freedom
Sample

Numbe

70

71

72

$73 \quad 2398$

$76 \quad 2438$

$77 \quad 2470$
Avg. Conc.

Area 2 Area 3 Area $(\mathrm{mg} / \mathrm{L})$

$\begin{array}{llll}2315 & 2167 & 2232 & 14\end{array}$

$2410 \quad 15$

$2329 \quad 14$

$2398 \quad 15$

$2438 \quad 15$

$2470 \quad 15$
$X$ Coefficient(s) $\quad 159.6$

Std Err of Coef. $\quad 3.315$ 
Stand

Conc

(mg/L) Area 1 Area 2 Area 3

0.0

$15.0 \quad 2050 \quad 2066$

$59.2 \quad 5370 \quad 5362$

$\begin{array}{lll}150.0 & 10135 & 10121\end{array}$
Fit

Avg. Conc

Area (mg/L)
Constant

Std Err of $Y$ Est

$R$ Squared

No. of Observations

Degrees of Freedom

$2058 \quad 10$

$5366 \quad 66 \quad \times$ Coefficient(s)

$10128 \quad 148 \quad$ Std Err of Coef.
1464.85

533.157

0.99136

Sample

Avg. Conc.

Numbe Area 1 Area 2 Area 3 Area (mg/L)

$78 \quad 2632$

$2632 \quad 20$

$79 \quad 2552$

$2552 \quad 19$

$80 \quad 2878$

$2878 \quad 24$

$81 \quad 2888$

$2888 \quad 24$

$82 \quad 3069$

$3069 \quad 27$

$83 \quad 2972$

$2972 \quad 26$

$84 \quad 3169$

$3169 \quad 29$

$86 \quad 3091$

$3091 \quad 28$

$87 \quad 3118$

$3118 \quad 28$

$88 \quad 3142$

$3177 \quad 29$

$89 \quad 3082$

$3082 \quad 28$

$3133 \quad 28$

$3297 \quad 31$

$3334 \quad 32$

$3156 \quad 29$

$3407 \quad 33$ 
8-12-94 MW156

Stand

Conc

(mg/L) Area 1

0.0

$\begin{array}{lll}15.0 & 2311 & 2411\end{array}$

$59.2 \quad 5622 \quad 5732$

$150.0 \quad 10423 \quad 10056$
Fit

Avg.

Conc

(mg/L)

Constant

Std Err of $Y$ Est

$R$ Squared

No. of Observations

Degrees of Freedom

$2361 \quad 9$

$5677 \quad 67 \quad X$ Coefficient(s)

10240147 Std Err of Coef.
1821

589.8

0.989
Sample

Numbe

$\begin{array}{rrr}93 & 4078 & \\ 95 & 4020 & \\ 96 & 4261 & \\ 98 & 4323 & \\ 100 & 4185 & \\ 102 & 4300 & \\ 107 & 4790 & 4772 \\ 109 & 4858 & \\ 110 & 5072 & \end{array}$

Avg. Conc.

Area (mg/L)

$4078 \quad 39$

$4020 \quad 38$

$4261 \quad 43$

$4323 \quad 44$

$4185 \quad 41$

$4300 \quad 43$

$4700 \quad 50$

$4858 \quad 53$

$5072 \quad 57$ 
8-12-94 MW156

Stand

Conc

$(\mathrm{mg} / \mathrm{L})$ Area 1 Area 2 Area 3 Area

0.0

$15.0 \quad 2312 \quad 2165$

$59.2 \quad 5160 \quad 5149.7$

$150.0 \quad 10329 \quad 9785$

Avg.
Fit

Conc

Conc

$(\mathrm{mg} / \mathrm{L})$

Constant

Regression Output:

Std Err of Y Est

$R$ Squared

No. of Observations

Degrees of Freedom

$2239 \quad 12$

$5155 \quad 63$

$10057 \quad 149$
1532

285.5

0.997

3

1
Sample

Numbe Area 1 Area 2 Area 3

1124675

$114 \quad 4614$

$116 \quad 4998$

$118 \quad 5151$

$120 \quad 5280$

$122 \quad 5727$
Avg. Conc.

Area (mg/L)

$4675 \quad 55$

$4614 \quad 54$

$4998 \quad 60$

$5149 \quad 63$

$5280 \quad 65$

$5609 \quad 71$ 
8-13-94 MW156

Stand

Conc

$(\mathrm{mg} / \mathrm{L})$ Area 1 Area 2 Area 3

0.0

$\begin{array}{lll}15.0 & 2426 \quad 2463\end{array}$

$\begin{array}{lll}59.2 & 6279.5 & 6078\end{array}$

$150.0 \quad 12294 \quad 12160$
Fit

Avg. Conc

(mg/L)

Constant

Regression Output:

Area

Sample

Numbe Area 1 Area 2

124

127

129

131

133

5262

5945

6017

6232

6288

135

6420

$138 \quad 6944$

$140 \quad 6819$

$142 \quad 6568$
2445

6179

12227
Std Err of Y Est

$R$ Squared

No. of Observations

Degrees of Freedom

12

64

148
$X$ Coefficient(s) $\quad 71.59$

Std Err of Coef. $\quad 4.372$

Avg. Conc.

Area (mg/L)

$5262 \quad 51$

$5903 \quad 60$

$6017 \quad 62$

$6232 \quad 65$

$6288 \quad 65$

$6420 \quad 67$

$6944 \quad 75$

$6819 \quad 73$

$6568 \quad 69$
1600

425.5

0.996

3 
Stand

Conc

(mg/L) Area 1

0.0

0.88

3.3

15.0
Fit

Avg. Conc

Area 2 Area 3 Area

(mg/L)

Constant

Std Err of $Y$ Est

$R$ Squared

No. of Observations

Degrees of Freedom

0.7

161

615

2438
3.5 X Coefficient(s)

15.0 Std Err of Coef.
51.4455

48.709

0.99918

3

1

Sample

Avg. Conc.

Numbe Area 1 Area 2 Area 3 Area (mg/L)

$\begin{array}{rcrr}24 & 48 & 48 & <1 \\ 25 & \text { no TCE peak } & 0 & <1 \\ 30 & \text { no TCE peak } & 0 & <1 \\ 32 & \text { no TCE peak } & 0 & <1 \\ 35 & \text { no TCE peak } & 0 & <1 \\ 39 & \text { no TCE peak } & 0 & <1\end{array}$


8-14-94 MW156

Stand

Conc

(mg/L) Area 1 Area 2 Area 3 Area 4 Area 5

0.0

59.2

59.
150.0

371.0

Sample

Numbe Area 1 Area 2 Area 3

$143 \quad 4115$

$144 \quad 5009$

$145 \quad 4520$

$147 \quad 4580$

$149 \quad 4738$

$150 \quad 5053$

$153 \quad 5066$

$154 \quad 5724$

$158 \quad 5749$

$160 \quad 5653$

\section{$5227 \quad 5242$}

Avg. Conc.

Area $(\mathrm{mg} / \mathrm{L})$

Constant

Regression Output:

$4115 \quad 51 \quad$ Std Err of $Y$ Est

$5009 \quad 80 \quad$ R Squared

4520

4580

4738

5053

64

No. of Observations

Degrees of Freedom

71

5178

5724

5749

5653

81

$X$ Coefficient(s)

85 Std Err of Coef.
Fit

Conc

(mg/L)

$\begin{array}{rr}4077 & 50 \\ 7592 & 163 \\ 13980 & 367\end{array}$ 
Stand

Conc

(mg/L) Area 1 Area 2 Area 3 Area

0.0

$\begin{array}{rrr}72.2 & 6224 & 6163\end{array}$

$\begin{array}{llll}135.0 & 10566 & 10050 & 10364\end{array}$

$\begin{array}{lll}617.0 & 30920 & 31548\end{array}$
Fit

Avg. Conc

(mg/L)

$6194 \quad 59$

$10327 \quad 150$

$31234 \quad 615$
Regression Output:

Constant

3560

Std Err of $Y$ Est

930.3

0.998

$R$ Squared

\section{3}

Degrees of Freedom

1
Sample

Numbe. Area 1

16310788

$164 \quad 10670$

$\begin{array}{ll}166 & 10507\end{array}$

$\begin{array}{ll}167 & 12871\end{array}$

$\begin{array}{lll}169 & 12948\end{array}$

$171 \quad 12376$

$174 \quad 13359$

$176 \quad 13203$

$178 \quad 13905$

$180 \quad 14355$

18213660

$184 \quad 14801$

$185 \quad 14800$

$187 \quad 17256$

$188 \quad 15353$

$190 \quad 16077$

$192 \quad 16213$

$193 \quad 15488$
Avg. Conc.

Area 2 Area 3 Area (mg/L)

$10719 \quad 10754 \quad 160$

$10670 \quad 158$

$10507 \quad 154$

$12871 \quad 207$

$12948 \quad 209$

$12376 \quad 196$

$13359 \quad 218$

$13203 \quad 214$

$13905 \quad 230$

$\begin{array}{llll}14561 & 14964 & 14627 & 246\end{array}$

$13660 \quad 225$

$14801 \quad 250$

$14800 \quad 250$

$17256 \quad 304$

$15353 \quad 262$

$16077 \quad 278$

$16213 \quad 281$

$15488 \quad 265$
$X$ Coefficient(s) $\quad 44.98$

Std Err of Coef. $\quad 2.207$ 
8-23-94 MW156

Stand

Conc

(mg/L)

L)

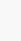

\begin{tabular}{|c|c|c|c|c|c|c|c|c|}
\hline \multirow{4}{*}{$\begin{array}{l}\text { Stand } \\
\text { Conc } \\
(\mathrm{mg} / \mathrm{L})\end{array}$} & \multirow{4}{*}{ Area 1} & \multirow{4}{*}{ Area 2} & \multirow{4}{*}{ Area 3} & \multirow{3}{*}{\multicolumn{2}{|c|}{$\begin{array}{l}\text { Fit } \\
\text { Conc } \\
(\mathrm{mg} / \mathrm{L})\end{array}$}} & \multicolumn{3}{|c|}{ Regression Output: } \\
\hline & & & & & & Constant & & 3047.1 \\
\hline & & & & & & Std Err of $Y$ Est & & 899.74 \\
\hline & & & & & & R Squared & & 0.9959 \\
\hline & & & & & & No. of Observations & & 3 \\
\hline 0.0 & & & & & & Degrees of Freedom & & 1 \\
\hline 135.0 & 8337 & 8094 & 8288 & 8240 & 126 & & & \\
\hline 371.0 & 18581 & 19583 & & 19082 & 389 & $X$ Coefficient(s) & 41.24 & \\
\hline 617.0 & 28459 & 27807 & & 28133 & 608 & Std Err of Coef. & 2.64 & \\
\hline
\end{tabular}

Sample

Numbe Area 1

$187 \quad 11138$

$\begin{array}{lll}190 & 11354 & 10705\end{array}$

$193 \quad 11922$

$\begin{array}{lll}195 & 12013 & 12072\end{array}$

$\begin{array}{lll}196 & 11574 & 11701\end{array}$

$198 \quad 12405$

20413301

$211 \quad 13989$

$212 \quad 13785$

$214 \quad 13604$

$219 \quad 14381$

$220 \quad 12902$

$222 \quad 13828$

$225 \quad 14404$

$227 \quad 13493$
Avg. Conc.

Area 2 Area 3 Area (mg/L)

$11138 \quad 196$

$11030 \quad 194$

$11922 \quad 215$

$12043 \quad 218$

$11668 \quad 209$

$12405 \quad 227$

$13301 \quad 249$

$13989 \quad 265$

$13785 \quad 260$

$13604 \quad 256$

$14381 \quad 275$

$\begin{array}{llll}13428 & 12420 & 12917 & 239\end{array}$

$13828 \quad 261$

$14404 \quad 275$

$13493 \quad 253$ 
8-25-94 MW156

Stand

Conc

$(\mathrm{mg} / \mathrm{L})$ Area 1 Area 2 Area 3 Area

0.0

135.0

$\begin{array}{lll}371.0 & 47887 & 51320\end{array}$

$617.0 \quad 72325 \quad 70523$
Fit

Avg. Conc (mg/L)

Constant

Regression Output:

Std Err of $Y$ Est

$R$ Squared

No. of Observations

Degrees of Freedom

119

402

602

$X$ Coefficient(s)

Std Err of Coef.

106.6

71424
7285

4057

0.988

3

$\begin{array}{cccccc}\begin{array}{c}\text { Sample } \\ \text { Numbe }\end{array} & \text { Area 1 } & \text { Area 2 } & \text { Area 3 } & \begin{array}{l}\text { Avg. } \\ \text { Area }\end{array} & \begin{array}{r}\text { Conc. } \\ \text { (mg/L) }\end{array} \\ 243 & 42081 & 41287 & & 41684 & 323 \\ 246 & 36623 & 37410 & & 37017 & 279 \\ 248 & 37962 & 34295 & 39028 & 37095 & 280 \\ 249 & 35859 & 38887 & & 37373 & 282 \\ 251 & 40717 & 43506 & & 42112 & 327\end{array}$


8-25-94

MW156

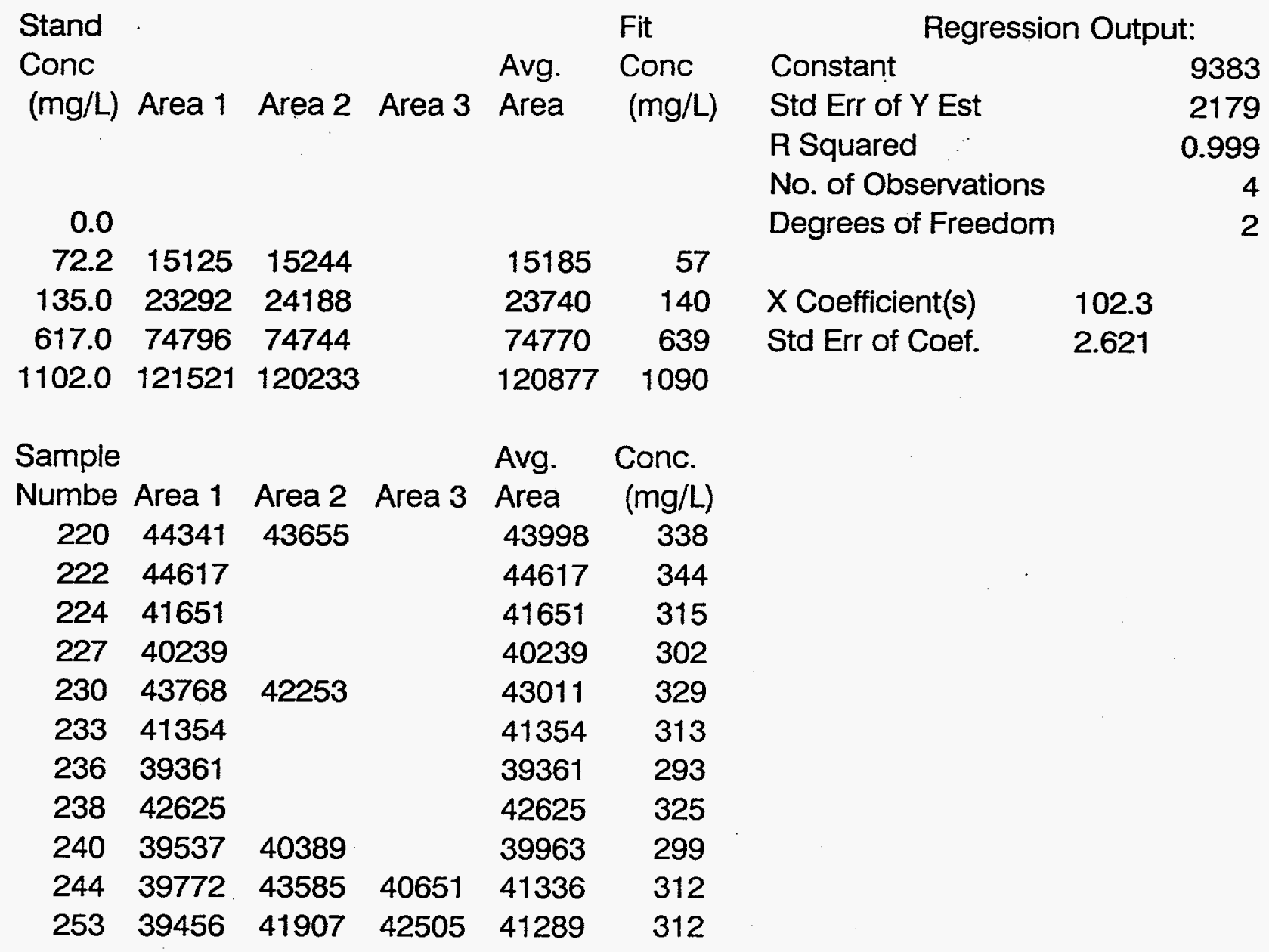


8-15-94 MW156 DCE Concentration Measurements

\begin{tabular}{|c|c|c|c|c|c|c|c|c|}
\hline \multirow{4}{*}{$\begin{array}{l}\text { Stand } \\
\text { Conc } \\
\text { (mg/L) }\end{array}$} & \multirow{4}{*}{ Area 1} & \multirow{4}{*}{ Area 2} & \multirow{4}{*}{ Area 3} & \multirow{3}{*}{\multicolumn{2}{|c|}{$\begin{array}{l}\text { Fit } \\
\text { Conc } \\
\text { (mg/L) }\end{array}$}} & \multicolumn{3}{|c|}{ Regression Output: } \\
\hline & & & & & & Constant & & 46.5505 \\
\hline & & & & & & Std Err of $Y$ Est & & 66.3439 \\
\hline & & & & & & $\begin{array}{l}\text { lared } \\
\text { f Observations }\end{array}$ & & 0.9999 \\
\hline 0.00 & & & & 0 & -0.09 & Degrees of Freedom & & \\
\hline 0.46 & 277 & 379 & 368.5 & 342 & 0.55 & & & \\
\hline 30.40 & 16263 & 16566 & & 16415 & 30.40 & $\begin{array}{l}\text { X Coefficient(s) } \\
\text { Std Err of Coeff }\end{array}$ & $\begin{array}{l}538.4 \\
2.693\end{array}$ & \\
\hline
\end{tabular}

$\begin{array}{rrrrrrr}\begin{array}{l}\text { Sample } \\ \text { Numbe }\end{array} & \text { Area 1 } & \text { Area 2 } & \text { Area 3 } & \begin{array}{c}\text { Avg. } \\ \text { Area }\end{array} & \begin{array}{c}\text { Approx. } \\ \text { Conc. } \\ \text { (mg/L) }\end{array} \\ 17 & 103 & 302 & & 203 & 0.3 \\ 50 & 845 & 765 & 556 & 722 & 1.3 \\ 81 & 284 & & & 284 & 0.4 \\ 117 & 175 & & & 175 & 0.2 \\ 148 & 356 & 176 & & 266 & 0.4 \\ 165 & 390 & & & 390 & 0.6 \\ 170 & 323 & 411 & 412 & 382 & 0.6\end{array}$

Approx.

$\begin{array}{rrrcc} & & \begin{array}{c}\text { Time } \\ \text { Since } \\ \text { Extraction } \\ \text { Segun }\end{array} & \begin{array}{c}\text { Approximate } \\ \text { DCE } \\ \text { Concentration } \\ \text { Numbe Day of } \\ \text { Measurement } \\ \text { (days) }\end{array} & \begin{array}{c}\text { Hour } \\ \text { (mg/L) }\end{array} \\ 50 & 3 & 23.5 & -5.60 & 0.3 \\ 81 & 11 & 22 & 0.33 & 1.3 \\ 117 & 12 & 4 & 1.58 & 0.4 \\ 148 & 13 & 13 & 2.96 & 0.2 \\ 165 & 14 & 20 & 5.13 & 0.4 \\ 170 & 15 & 11 & 5.88 & 0.6 \\ & & & & 0.6\end{array}$


Appendix E

\section{Calibration, Precision, and Regression Statistics for Field Surfactant Analyses}


Surfactant Concentration Calibration Curves

8-12-94

\begin{tabular}{|c|c|c|}
\hline $\begin{array}{l}\text { Stand } \\
\text { Conc } \\
\text { (\% by wt) }\end{array}$ & ABS & $\begin{array}{l}\text { Fit } \\
\text { Conc } \\
\text { (\% by wt) }\end{array}$ \\
\hline $0.000 \%$ & -0.008 & $-0.000 \%$ \\
\hline $0.015 \%$ & 0.079 & $0.013 \%$ \\
\hline $0.038 \%$ & 0.249 & $0.040 \%$ \\
\hline $0.112 \%$ & 0.698 & $0.111 \%$ \\
\hline
\end{tabular}

Regression Output:

Constant

$-0.0062$

Std Err of $Y$ Est

0.01174

$R$ Squared

0.99907

No. of Observations

4

Degrees of Freedom

2

$X$ Coefficient(s) $\quad 631.935$

Std Err of Coef. 13.6351

8-13-94

\begin{tabular}{lrr}
$\begin{array}{l}\text { Stand } \\
\text { Conc } \\
\text { (\% by wt) }\end{array}$ & ABS & \multicolumn{2}{l}{$\begin{array}{l}\text { Fit } \\
\text { Conc } \\
\text { (\% by wt) }\end{array}$} \\
& & \\
$0.000 \%$ & -0.006 & $-0.000 \%$ \\
$0.015 \%$ & 0.085 & $0.014 \%$ \\
$0.038 \%$ & 0.254 & $0.040 \%$ \\
$0.112 \%$ & 0.708 & $0.111 \%$
\end{tabular}

Regression Output:

Constant

$-0.0029$

Std Err of $Y$ Est

0.01094

$R$ Squared

0.99921

No. of Observations

4

Degrees of Freedom

2

$X$ Coefficient(s) $\quad 638.017$

Std Err of Coef. 12.7042

8-14-94

\begin{tabular}{|c|c|c|}
\hline Stand & & Fit \\
\hline $\begin{array}{l}\text { Conc } \\
\text { (\% by wt) }\end{array}$ & ABS & $\begin{array}{l}\text { Conc } \\
\text { (\% by wt) }\end{array}$ \\
\hline $0.000 \%$ & -0.009 & $-0.001 \%$ \\
\hline $0.015 \%$ & 0.084 & $0.014 \%$ \\
\hline $0.038 \%$ & 0.257 & $0.040 \%$ \\
\hline $0.112 \%$ & 0.720 & $0.111 \%$ \\
\hline
\end{tabular}

Regression Output:

Constant

$-0.0057$

Std Err of $Y$ Est

0.01147

$R$ Squared

0.99916

No. of Observations

Degrees of Freedom

$X$ Coefficient(s) $\quad 651.367$

Std Err of Coef. 13.3182

$8-21-94$

\begin{tabular}{|c|c|c|}
\hline $\begin{array}{l}\text { Stand } \\
\text { Conc } \\
\text { (\% by wt) }\end{array}$ & ABS & $\begin{array}{l}\text { Fit } \\
\text { Conc } \\
\text { (\% by wt) }\end{array}$ \\
\hline $0.000 \%$ & -0.004 & $-0.000 \%$ \\
\hline $0.009 \%$ & 0.052 & $0.008 \%$ \\
\hline $0.015 \%$ & 0.087 & $0.014 \%$ \\
\hline $0.038 \%$ & 0.260 & $0.041 \%$ \\
\hline $0.112 \%$ & 0.718 & $0.111 \%$ \\
\hline
\end{tabular}

Regression Output:

Constant

$-0.0022$

Std Err of $Y$ Est

0.00999

$R$ Squared

0.99913

No. of Observations

Degrees of Freedom

$X$ Coefficient(s) $\quad 646.676$

Std Err of Coef. $\quad 10.9979$ 
Precision Calculations

Field Surfactant Triplicates

\begin{tabular}{|c|c|c|c|c|c|c|c|}
\hline & & & & & & $\begin{array}{l}\text { Student t } \\
95 \% \text { Confio }\end{array}$ & dence Interval \\
\hline $\begin{array}{l}\text { Sample } \\
\text { Number }\end{array}$ & $\begin{array}{l}\text { Conc. } \\
\text { (\% by wt) }\end{array}$ & $\begin{array}{l}\text { Conc. } \\
\text { (\% by wt) }\end{array}$ & $\begin{array}{l}\text { Conc. } \\
\text { (\% by wt) }\end{array}$ & $\begin{array}{l}\text { Sample } \\
\text { Standard } \\
\text { Deviation } \\
\text { (\% by wt) }\end{array}$ & $\begin{array}{l}\text { Sample } \\
\text { Mean } \\
\text { Conc. } \\
\text { (\% by wt) }\end{array}$ & $\begin{array}{c}+/- \\
(\% \text { by wt) }\end{array}$ & $\begin{array}{c}+/- \\
(\% \text { of mean })\end{array}$ \\
\hline 44 & $1.050 \%$ & $1.020 \%$ & $1.050 \%$ & $0.017 \%$ & $1.040 \%$ & $0.043 \%$ & $4.1 \%$ \\
\hline 70 & $0.550 \%$ & $0.570 \%$ & $0.560 \%$ & $0.010 \%$ & $0.560 \%$ & $0.025 \%$ & $4.4 \%$ \\
\hline 172 & $0.005 \%$ & $0.006 \%$ & $0.007 \%$ & $0.001 \%$ & $0.006 \%$ & $0.002 \%$ & $41.4 \%$ \\
\hline
\end{tabular}




\title{
Appendix $F$
}

\author{
MW-155 \\ Gas Chromatograph Data
}


MW-155

Stand

Conc

(mg/L)

0.0

$\begin{array}{llll}0.88 & 156.4 & 159.4\end{array}$

$\begin{array}{lll}3.3 & 582.8 & 573.7\end{array}$

$\begin{array}{lll}15.0 & 2338 & 2442\end{array}$
Fit

Avg. Conc

Area 1 Area 2 Area 3 Area (mg/L)
Regression Output:

Constant

37.941

28.852

0.9997

R Squared

No. of Observations

Degrees of Freedom
Sample

Numbe Area 1

$\begin{array}{rr}2 & 259 \\ 9 & 78 \\ 26 & 59\end{array}$
158

578

2390
0.8

3.4

$X$ Coefficient(s)

Std Err of Coef.
157.1

2.702

8-7-94

Avg. Conc.

Area 2 Area 3 Area (mg/L)

$259 \quad 1.4$

$78<1$

$72<1$

Stand

MW-155

Conc

Fit

Avg. Conc

Constant

Regression Output:

(mg/L)

Area 1 Area 2

Area 3 Area

0.0

0.88

55.8

55

(mg/L)

Std Err of $Y$ Est

$-92.95$

$R$ Squared

48.214

No. of Observations

0.9988

Degrees of Freedom

3.3

309

1.1

1908

3.0

$X$ Coefficient(s)

133

$\begin{array}{ll}15.0 & 1907.7\end{array}$

15.0

Std Err of Coef.

4.515

Sample

Numbe $28 \quad 90.2$

$29 \quad 16.4$
Avg. Conc.

Area 2 Area 3 Area (mg/L)

$90 \quad 1.4$

$16<1$ 
Stand

Conc

(mg/L) Area 1 Area 2 Area 3

0.0

0.88

3.3

15.0
10241016.5 $\begin{array}{rr}53.6 & 66 \\ 245.5 & 242\end{array}$
64.3

61

244

1020
Fit

Avg.

Conc

(mg/L)

Constant

Std Err of $Y$ Est

$R$ Squared

No. of Observations

Degrees of Freedom

0.8

3.5

3.5
15.0
$X$ Coefficient(s)

Std Err of Coef.
Regression Output:

10.706

13.815

0.9996

\section{3}

1
Sample

Numbe Area 1 Area 2 Area 3 33 45

34
Avg. Conc.

Area $(\mathrm{mg} / \mathrm{L})$

$45 "<1$

$46<1$
67.42

1.294

8-9-94

MW-155

Stand

Fit

Conc

Avg.

Conc

Constant

Regression Output:

$(\mathrm{mg} / \mathrm{L})$ Area 1 Area 2 Area 3

Area

$\begin{array}{rrr}0.0 & & \\ 0.88 & 52.5 & 56.8 \\ 3.3 & 308 & 322.8 \\ 15.0 & 1492 & 1465\end{array}$
55
315

(mg/L)

Std Err of Y Est

$-25.62$

$R$ Squared

12.763

No. of Observations

0.9999

Degrees of Freedom

Sample

0.8

3.4

$X$ Coefficient(s)

100.4

1479

15.0

Std Err of Coef.

1.195

Numbe

Avg. Conc.

36

Area 1 Area 2 Area 3

Area

(mg/L)

38 too low for integration
$<1$
$<1$


8-10-94

MW-155

Stand

Conc

(mg/L)

(mg/L)

0

$\begin{array}{lll}0.9 & 49.1 & 45.5\end{array}$

$\begin{array}{lll}3.3 & 402.9 & 432.6\end{array}$

$\begin{array}{lll}15.0 & 2301.7 & 2299.6\end{array}$
Fit

Avg. Conc

Area 3 Area (mg/L)

Regression Output:

Constant

Std Err of $Y$ Est

$-101.12$

$R$ Squared

12.0214

0.99995

No. of Observations

Degrees of Freedom

1

$418 \quad 3$

$2301 \quad 15$

$X$ Coefficient(s)

160

Std Err of Coef.

1.126

Sample

Numbe Area

$\begin{array}{rr}42 & 92.6 \\ 60 & 127 \\ 69 & 125\end{array}$

$69 \quad 125$
Avg. Conc.

Area 2 Area 3 Area $(\mathrm{mg} / \mathrm{L})$

$93 \quad 1.2$

$127 \quad 1.4$

$125 \quad 1.4$

8-11-94

MW-155

Stand

Conc

(mg/L) Area 1 Area 2 Area 3 Area 4 Area 5

Avg.

Fit

Area

Conc

0.0

$0.88 \quad 124 \quad 106$

$\begin{array}{lllll}3.3 & 442 & 499 & 499 & 454\end{array}$

$\begin{array}{rr}115 & 0.8 \\ 474 & 3.4 \\ 2034 & 15.0\end{array}$

$\begin{array}{llll}15.0 & 1987 & 2050 & 2066\end{array}$

Avg. Conc.

Sample

Area (mg/L)

Regression Output:

Numbe

154

1.1

Constant

10.3556

$\begin{array}{ll}85 & 154 \\ 94 & 171\end{array}$

171

1.2

Std Err of $Y$ Est

22.5574

$R$ Squared

0.99976

No. of Observations

Degrees of Freedom

$X$ Coefficient(s)

Std Err of Coef. 
Stand

Conc

(mg/L)

0.0

0.88

3.3

52

61

382

$\begin{array}{rrr}15.0 & 1871 \quad 1829\end{array}$
Fit

Avg. Conc

Area 3 Area (mg/L)
Constant

Std Err of $Y$ Est

$R$ Squared

No. of Observations

Degrees of Freedom
$-47.982$

8.42754

0.99996

61.3

58

0.8

376

3.4

$X$ Coefficient(s)

126.6

1850

Std Err of Coef.

0.789

Sample

Numbe

111
Area

115
Avg. Conc.

Area 2 Area 3 Area $(\mathrm{mg} / \mathrm{L})$

$115 \quad 1.3$

8-13-94

MW-155

Stand

Conc

(mg/L)

(mg/L)

0.0

0.88

3.3

15.0
149

621

2424

$$
168
$$

166

609

2426

2463
Fit

Avg.

Area
161

615

Conc

(mg/L)

2438

0.7
3.5 X Coefficient(s) 159.5

15.0 Std Err of Coef.

159.5
4.561
Regression Output:

Constant

51.4455

48.709

$R$ Squared

0.99918

No. of Observations

Degrees of Freedom
Sample

Numbe Area

121

137

146
169

148

164
Avg. Conc.

Area (mg/L)

$169<1$

$148<1$

$164<1$ 


\section{$\log$}

Stand Stand

Conc Conc

$(\mathrm{mg} / \mathrm{L}) \quad(\mathrm{mg} / \mathrm{L}) \quad$ Area 1 Area 2 Area 3

0.0

$\begin{array}{rrrr}0.92 & -0.036 & 23264 & 24629 \\ 1.9 & 0.279 & 35506 & 35593 \\ 4.9 & 0.690 & 53364 & 53393 \\ 0.88 & -0.056 & 24191 & 23754 \\ 3.3 & 0.519 & 46485 & 46341\end{array}$

Sample

Numbe Area 1

$34 \quad 30171$

$36 \quad 26185$

$38 \quad 28510$

$42 \quad 28678$

$60 \quad 29514$

$69 \quad 29643$

$85 \quad 29550$

9430200

$111 \quad 30410$

$121 \quad 27538$

$137 \quad 28833$

$146 \quad 30540$

$157 \quad 30458$

$162 \quad 30547$

$168 \quad 29869$

$173 \quad 30126$

$179 \quad 30717$

$183 \quad 30932$

$186 \quad 30857$

$191 \quad 29087$

$194 \quad 32621$

$199 \quad 32242$

$202 \quad 32579$

Log
Log Fit

Avg. Conc Constant

( $\mathrm{mg} / \mathrm{L}) \quad$ Std Err of Y Est

$R$ Squared

No. of Observations

$\begin{array}{lll}4.38 & 0.9 & \text { Degrees of Freedom }\end{array}$

$4.55 \quad 2.0$

$4.73 \quad 4.6 \quad \times$ Coefficient(s)

$4.38 \quad 0.9 \quad$ Std Err of Coef.

$4.67 \quad 3.5$
Regression Output:

4.406

0.012

0.996

Avg. Conc.

Area 2 Area 3 Area (mg/L)

$4.48 \quad 1.4$

$4.42 \quad 1.1$

$4.45 \quad 1.3$

$4.46 \quad 1.3$

$4.47 \quad 1.4$

$4.47 \quad 1.4$

$4.47 \quad 1.4$

$4.48 \quad 1.4$

$4.48 \quad 1.4$

$4.44 \quad 1.2$

$4.46 \quad 1.3$

$4.48 \quad 1.5$

$4.48 \quad 1.4$

$4.48 \quad 1.5$

$4.48 \quad 1.4$

$4.48 \quad 1.4$

$4.49 \quad 1.5$

$4.49 \quad 1.5$

$4.49 \quad 1.5$

$4.46 \quad 1.3$

$4.51 \quad 1.7$

$4.51 \quad 1.6$

$4.51 \quad 1.7$ 
Log

Stand Stand

Conc Conc

$(\mathrm{mg} / \mathrm{L}) \quad(\mathrm{mg} / \mathrm{L})$

0.0

0.92

1.9

4.9 $-0.036$

0.279

2183322059

0.690

32145

31460

48629
48866

Log Fit

Avg. Conc

Area 3 Area (mg/L)

$4.50 \quad 2.0$

4.69

4.8
Logarithmic Regression

Regression Output:

Constant

4.362

Std Err of $Y$ Est

0.007

$R$ Squared

0.999

No. of Observations

$4.34 \quad 0.9$ Degrees of Freedom

$X$ Coefficient(s)

0.482

Std Err of Coef.

0.014

Log

Sample

Avg. Conc.

Numbe Area 1

$\begin{array}{rr}28 & 27588 \\ 29 & 27198 \\ 33 & 27744 \\ 34 & 27623 \\ 207 & 28101 \\ 210 & 28847 \\ 215 & 28723 \\ 218 & 29968\end{array}$

Area 2 Area 3 Area $(\mathrm{mg} / \mathrm{L})$

$4.44 \quad 1.5$

$4.43 \quad 1.4$

$4.44 \quad 1.5$

$4.44 \quad 1.5$

$4.45 \quad 1.5$

$4.46 \quad 1.6$

$4.46 \quad 1.6$

$4.48 \quad 1.7$ 
8-25-94 MW-155

$\log$

Stand Stand

Log Fit

Logarithmic Regression

Conc Conc

Avg. Conc

Regression Output:

$(\mathrm{mg} / \mathrm{L}) \quad(\mathrm{mg} / \mathrm{L}$

Area 1 Area 2 Area 3

Area

$(\mathrm{mg} / \mathrm{L})$

4.399

Std Err of $Y$ Est

0.006

R Squared

0.999

No. of Observations

0.92

$-0.036$

$\begin{array}{lll}25412 & 22760 & 23769\end{array}$

4.38

0.9

Degrees of Freedom

$\begin{array}{lllll}1.9 & 0.279 & 32802 & 34873 & 34356\end{array}$

$4.53 \quad 1.9$

4.9

$0.690 \quad 51823 \quad 51451$

4.71

4.8

$X$ Coefficient(s)

0.458

Std Err of Coef.

0.012

$\log$

Sample

Avg. Conc.

Numbe Area 1

Area 2 Area 3 Area (mg/L)

$223 \quad 30569$

$226 \quad 32761$

$4.49 \quad 1.5$

$231 \quad 30967$

$4.52 \quad 1.8$

$234 \quad 31332$

$4.49 \quad 1.6$

$239 \quad 31774$

$4.50 \quad 1.6$

$241 \quad 32505$

$4.50 \quad 1.7$

$247 \quad 31206$

$4.51 \quad 1.8$

$250 \quad 32102$

$4.49 \quad 1.6$

$4.51 \quad 1.7$

$\begin{array}{llll}252 & 36159 & 34144 & 37297\end{array}$

$4.55 \quad 2.2$ 